UNIVERSIDADE DE SÃO PAULO INSTITUTO DE GEOCIÊNCIAS
UNIVERSITÉ DE MONTPELLIER ॥ ISTEEM

\title{
RELAÇÕES ENTRE MICROESTRUTURAS, MECANISMOS DE DEFORMAÇÃO E PROPRIEDADES FÍSICAS ANISOTRÓPICAS EM ROCHAS DE ALTO GRAU DE METAMORFISMO: ESTUDO DE ALGUNS ECLOGITOS E GRANULITOS
}

\author{
JÉRÔME FERNAND LOUIS BASCOU
}

Orientadores: Prof. Dr. Marcos Egydio da Silva Prof. Dr. Alain Vauchez

TESE DE DOUTORAMENTO

Nome

Assinatura

Presidente: Prof. Dr. Marcos Egydio da Silva

Examinadores: Prof. Dr. Alain Vauchez

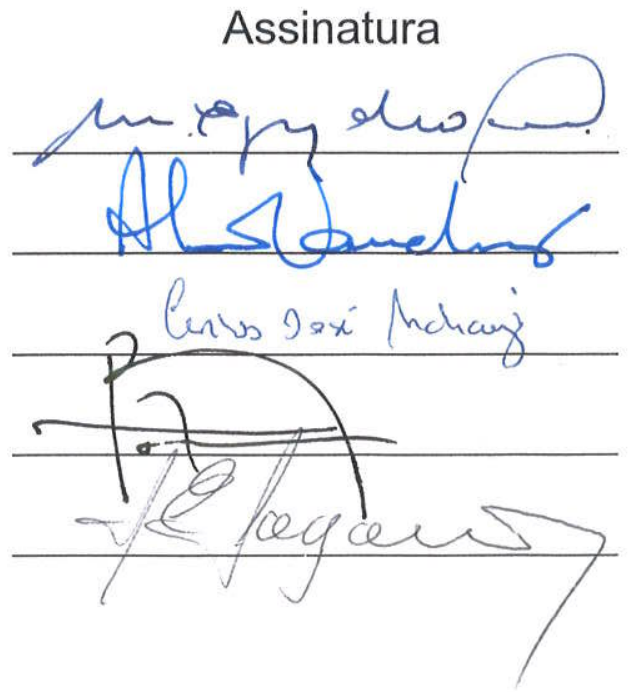

SÃO PAULO

2002 
UNIVERSIDADE DE SÃO PAULO

INSTITUTO DE GEOCIENCIAS

UNIVERSITÉ DE MONTPELLIER ॥
ISTEEM

RELAÇÕES ENTRE MICROESTRUTURAS, MECANISMOS DE DEFORMAÇĀO E PROPRIEDADES FÍSICAS ANISOTRÓPICAS EM ROCHAS DE ALTO GRAU DE METAMORFISMO: ESTUDO DE ALGUNS ECLOGITOS E GRANULITOS

\author{
Jérôme Fernand Louis Bascou \\ Orientador: Prof. Dr. Marcos Egydio Silva \\ Prof. Dr. Alain Vauchez
}

TESE DE DOUTORAMENTO

Programa de Pós-Graduação em Geoquímica e Geotectônica

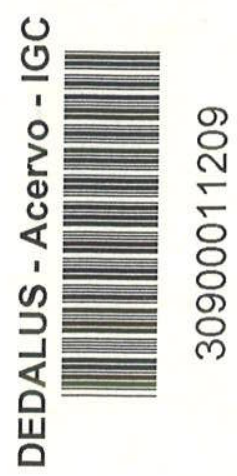


À la mémoire de mon père À tous ceux qui me sont chers 


\section{RESUMO}

A deformação dúctil tem como consequiência uma anisotropia das propriedades físicas das rochas associada ao desenvolvimento de uma orientação cristalográfica dos minerais. No presente trabalho, os mecanismos de deformação nas rochas de alto grau de metamorfismo e as relações entre o fluxo e a anisotropia das propriedades físicas são estudados a partir da análise das microestruturas e da medida das orientações preferenciais de rede (OPR) dos principais minerais que constituem eclogitos e granulitos. As OPR dos minerais são obtidas através da análise das figuras de difração dos elétrons retroespalhados (técnica EBSD).

Os eclogitos provêm dos Alpes, da Noruega, do Mali e da faixa Sulu-Dabishan, na China. As microestruturas são marcadas pela deformação dúctil da onfacita. Apesar da diversidade dos locais de amostragem, as OPR da onfacita das diferentes amostras apresentam características similares e relações simples com os eixos da deformação finita $\mathrm{X}, \mathrm{Y}$ e Z : os eixos cristalográficos [010] tendem a concentrar -se paralelamente à $Z$ e os eixos [001], paralelamente à lineação (X). A utilização de um modelo numérico de deformação viscoplástica evidenciou o papel dos planos de deslizamentos equivalentes $\{110\}$ no desenvolvimento das OPR das onfacitas. Além disso, as variações das OPR das onfacita estão ligadas a variações do regime de deformação em condiçōes de alta pressão.

A medida das OPR das onfacitas e das granadas permitiram determinar as propriedades sísmicas dos eclogitos. Apesar das microestruturas evidenciarem uma intensa deformação, os eclogitos caracterizam-se por uma baixa anisotropia sísmica (AVp et AVs $<3 \%$ ). O cálculo dos coeficientes de reflexão mostra que os corpos eclogíticos na crosta constituem refletores sísmicos muito fortes, enquanto que uma interface eclogito-peridotito permaneceria invisível pela técnica de sísmica de reflexão.

Os granulitos foram coletados em uma ampla zona milonítica que aflora na faixa neoproterozóica Ribeira, ao longo de grandes cisalhamentos de escala litosférica, no SE do Brasil. As microestruturas e as OPR do quartzo, dos feldspatos, dos piroxênios e dos óxidos de Fe-Ti sugerem mecanismos de deformação ativos a alta temperatura (deslizamento intra-cristalino e difusão) e de processos sin- e pós- cinemáticos. O quartzo é afetado por uma intensa recristalisação estática "annealing" que se traduz por um crescimento exagerado de seus grãos e pela formação de "ribbons" policristalinos. $O$ estudo das microestruturas sugere que a OPR de quartzo formada durante a deformação é profundamente modificada, e portanto que a assinatura sin-tectônica da OPR do quartzo é em grande parte suprimida. O plagioclásio, o ortopiroxênio e os óxidos da solução sólida "ilménitahematita" são menos sensíveis que o quartzo ao efeito do "annealing". Em particular, as OPR desses óxidos de Fe-Ti permitem uma melhor análise estrutural e cinemática dos granulitos, assim como uma melhor interpretação das medidas de anisotropia de susceptibilidade magnética.

O cálculo das propriedades sísmicas dos granulitos estudados permitiu avaliar o papel da milonitização na refletividade de uma zona de cisalhamento progradante na base da crosta, assim como a contribuição de uma tal zona de cisalhamento à defasagem das ondas S. As interfaces entre as rochas miloníticas e seus equivalentes não-deformados não constituem refletores sísmicos de qualidade, e a contribuição dos milonitos granulíticos à defasagem das ondas $S$, em domínio de transcorrência litosférica, permanece baixa em comparação com a defasagem que poderia ser gerada pelo manto superior. 


\section{RÉSUMÉ}

La déformation ductile a pour conséquence une anisotropie des propriétés physiques des roches associée au développement d'une orientation cristallographique des minéraux. Dans ce travail, les mécanismes de déformation dans des roches de haut degré de métamorphisme et les relations entre le fluage et l'anisotropie des propriétés physiques sont étudiés à partir de l'analyse des microstructures et de la mesure des orientations préférentielles de réseau (OPR) des principaux minéraux constituant des éclogites et des granulites. Les OPR des minéraux sont obtenues par analyse des figures de diffraction des électrons rétro diffusés (technique EBSD).

Les éclogites proviennent des Alpes, de Norvège, du Mali et de la chaîne Sulu-Dabishan en Chine. Les microstructures sont marquées par la déformation ductile de l'omphacite. Malgré la diversité des sites d'échantillonnage, les OPR d'omphacite des différents échantillons montrent des caractéristiques similaires et des relations simples avec les axes de la déformation fínie $X, Y$ et $Z$ : les axes cristallographiques [010] tendent à se concentrer parallèlement à $Z$ et les axes [001], parallèlement à la linéation $(\mathrm{X})$. L'utilisation d'un modèle numérique de déformation viscoplastique a mis en évidence le rôle des plans de glissement équivalents $\{110\}$ dans le développement des OPR des omphacites. De plus, les variations de l'OPR d'omphacite sont reliées à des variations du régime de déformation sous des conditions de haute pression.

La mesure des OPR d'omphacite et de grenat a permis de déterminer les propriétés sismiques des éclogites. Bien que les microstructures témoignent d'une forte déformation, les éclogites sont caractérisées par une faible anisotropie sismique ( $\mathrm{AVp}$ et $\mathrm{AVs}<3 \%$ ). Le calcul des coefficients de réflexion montre que les corps écologitiques dans la croûte constituent des réflecteurs sismiques très marqués, alors qu'une interface éclogite-péridotite resterait invisible en sismique réflexion.

Les granulites ont été prélevées dans une large zone mylonitique affleurant dans la chaîne néoprotérozoïque Ribeira, le long de grands cisaillements d'échelle lithosphérique, au SE du Brésil. Les microstructures et les OPR du quartz, des feldspaths, des pyroxènes et des oxydes de Fe-Ti relèvent de mécanismes de déformation actifs à haute température (glissement intra-cristallin et diffusion) et de processus syn- et post-cinématiques. Le quartz est affecté par un intense recuit postcinématique qui se traduit par une croissance exagérée de ses grains et la formation de larges rubans polycristallins. L'étude des microstructures suggère que l'OPR de quartz formée pendant la déformation est profondément modifiée, et donc que la signature syn-tectonique de l'OPR du quartz est en grande partie effacée. Le plagioclase, l'orthopyroxène et les oxydes de la solution solide "ilménite-hématite" sont moins sensibles que le quartz à l'effet du recuit post-cinématique. En particulier, les OPR de ces oxydes de Fe-Ti permettent une meilleure analyse structurale et cinématique des granulites, ainsi qu'une meilleure interprétation des mesures d'anisotropie de susceptibilité magnétique.

Le calcul des propriétés sismiques des granulites étudiées a permis d'évaluer le rôle de la mylonitisation sur la réflectivité d'une zone de cisaillement prograde en base de croûte, ainsi que la contribution d'une telle zone de cisaillement au déphasage des ondes S. Les interfaces entre les roches mylonitiques et leurs équivalents non-déformés ne constituent pas de forts réflecteurs sismiques, et la contribution des mylonites granulitiques au déphasage des ondes $S$, dans un décrochement lithosphérique, reste très faible en comparaison du déphase qui pourrait être généré par le manteau supérieur. 
ABSTRACT

Ductile deformation of rocks produces anisotropic properties associated to the development of crystallographic orientation of rock forming minerals. In this work, deformation mechanisms in high grade metamorphic rocks and the relationships between fluage and anisotropy of physical properties are studied from the analysis of microstructures and from measurements of lattice preferred orientations (LPO) of principal rock-forming minerals of eclogites and granulites. The LPO of minerals are determined using the electron backscattered diffraction technique (EBSD).

Eclogites come from the Alps, Norway, Mali and the Sulu-Dabishan belt in China. Microstructures record the ductile deformation of omphacite. In spite of the sampling site diversity, the omphacite LPO display similar main characteristics and simple relationships with the $\mathrm{X}, \mathrm{Y}$ and $\mathrm{Z}$ axes of the finite strain: the crystallographic axes [010] tend to concentrate parallel to $Z$ and the [001] axes tend to concentrate parallel to the lineation (X). The use of a numerical model of viscoplastic deformation highlights the role of equivalent glide planes $\{110\}$ in the development of omphacite LPO. In addition, variations of omphacite LPO are related to variations in deformation regime under high-pressure conditions.

Measurements of omphacite and garnet LPO allowed the calculation of the seismic properties of eclogites. Although the microstructures give evidence of strong deformation, eclogites are characterized by a week seismic anisotropy (AVp et AVs $<3 \%$ ). Calculation of reflection coefficients indicates that eclogite bodies embedded in the crustal rocks generate very bright seismic reflectors whereas an éclogite-péridotite interface should remains invisible to vertical seismic reflection techniques.

Granulites have been sampled in a wide mylonitic zone outcropping in the neoproterozoic Ribeira belt, along transcurrent faults of tithospheric scale, southeastern Brazil. Microstructures and LPO of quartz, feldspars, pyroxenes and Fe-Ti oxides are correlated with high-temperature deformation mechanisms (intra-crystalline glide and diffusion), and syn- and post-kinematics processes. Quartz is affected by annealing, which produces exaggerate grain growth and the development of polycrystalline ribbons. Microstructure analysis suggests that the initial quartz LPO, developed during the deformation, is profoundly altered and therefore, that the syn-tectonic features of the quartz LPO are significantly erased. Plagioclase, orthopyroxene and oxide of the "ilménitehématite" solid solution are less sensitive to annealing. In particular, these Ti-Fe oxide LPO allow a better structural and kinematic analysis of granulites, and a better interpretation of anisotropy of magnetic susceptibility measurements.

Calculation of seismic properties of studied granulites allows one to evaluate the role of the mylonitisation on the reflectivity of prograde shear zones within the deep crust, and the contribution of these shear zones to the S-wave splitting. Interfaces between mylonitic rocks and their un-deformed equivalents generate only very weak seismic reflections, and the S-wave splitting produced by the granulitic mylonites remain very weak in comparison of spliting that may be generated by the upper mantle. 


\section{AGRADECIMENTOS}

Gostaria de expressar meus sinceros agradecimentos aos Professores Marcos Egydio-Silva e Alain Vauchez, que me propuseram esta co-tutela e que durante estes quatro anos acompanharam-me nesta grande aventura entre São Paulo e Montpellier, enriquecendome com sua confiança e seus conselhos.

Este trabalho foi possível graças à bolsa de Doutorado concedida pela CAPES (Brasil) e ao auxílio financeiro do Ministério da Educação Nacional (aide à la co-tutelle, França).

Meus agradecimentos dirigem-se também :

Aos Professores Adilson Carvalho e Wilson Teixeira, por me terem acolhido no Instituto de Geociências da Universidade de São Paulo.

A toda a equipe do Laboratoire de Tectonophysique de l'Université Montpellier II, que há vários anos tem me acompanhado. Esta tese beneficiou particularmente da colaboração com D. Mainprice, A. Tommasi, G. Barruol e R. Caby.

Aos Professores Carlos J. Archanjo e Rômulo Machado, IG/USP, por seu interesse e seus conselhos durante o exame de qualificação.

A Dra. Irene Raposo, IG/USP, que favoreceu minha iniciação ao estudo da anisotropia magnética.

Ao Professor Ricardo Trindade, por nossas inúmeras conversas.

A Christophe Nevado, UMII, pela alta qualidade das lâminas delgadas e por sua disponibilidade.

Isaac Sayed (MEV, IG) e Marcos Mansueto (Microsonda, IG), por seu auxílio técnico, assim como aos funcionários do IG/USP que facilitaram a realização deste trabalho.

A todas as pessoas do ISTEEM que me apoiaram.

A Luciana Rassier, Christine Bourotte e Cristina Burgos, pela preciosa ajuda em relação à versão da tese em português.

A Bernadette, Anna Paula e Magali, por sua gentileza e competência, que me ajudaram a vencer os "obstáculos" administrativos. Agradeço igualmente a Tadeu, da secretaria da Pós-Graduação (IG/USP). 
Minha gratidão:

Aos colegas de escritório, pela atmosfera agradável que souberam manter. Em Montpellier, Benoit \& Benoit e Marianne; na USP, Valéria, Christine e Wânia. Obrigado a Cleide e Suelly por sua acolhida.

Aos doutorandos do laboratório GMG/IG-USP, por sua ajuda e por me terem feito descobrir a vida estudantil brasileira.

Aos doutorandos de Montpellier que me acompanharam neste percurso.

A Marie-Pierre Ledru, Priscila, Maggy, Chico Bill, Guillaume, Olivier, Eric, Laure, Kika, Mauro, e todas as pessoas que não cito mas das quais me lembro e com as quais compartilhei ótimos momentos.

Aos Professores Carlos J. Archanjo e Jean Luc Bouchez por terem sido os rapporteurs da tese.

Minha gratidão aos membros da banca, por terem aceitado examinar este trabalho.

Montpellier, 28 de setembro de 2002 


\section{ÍNDICE}

$\begin{array}{cl}\text { RESUMOS } & \text { i } \\ \text { AGRADECIMENTOS } & \text { iv }\end{array}$

INTRODUÇÃO GERAL 1

\section{Capítulo 1.}

Da deformação às propriedades físicas anisotrópicas 6

1.1. Abordagem experimental da deformação plástica 6

1.2. Mecanismos da deformação plástica

1.2.1. As discordâncias

1.2.2. A recuperação e a recristalização dinâmica : os mecanismos auxiliares do deslizamento 9

1.2.3. A migração dos limites de grão e o crescimento dos grãos $\quad 10$

$\begin{array}{ll}\text { 1.2.4. O fluxo por difusão e a superplasticidade } & 11\end{array}$

1.3. Deformação plástica e desenvolvimento das orientações preferenciais da rede 12

1.3.1. Deslizamento, geminação e desenvolvimento das OPR 12

$\begin{array}{ll}\text { 1.3.2. Interpretação cinemática das OPR } & 14\end{array}$

1.3.3. A medida das OPR: a técnica EBSD 16

1.3.3.1. Os principais instrumentos e técnicas de medida das OPR: a platina universal, os goniômetros e a microscopia eletrônica de varredura $\quad 16$

1.3.3.2. Formação das figuras de difração 18

1.3.3.3. Equipamento, condições de trabalho e preparação das amostras $\quad 20$

1.3.3.4. Indexação das figuras de difração 22

1.3.3.5. Precisão das orientações $\quad 25$

1.3.4. Representação das OPR 26

1.3.4.1. Os ângulos de Euler, a função de distribuição da orientação 26

1.3.4.2. As figuras de póle e os mapas de orientação 29

1.4. As propriedades físicas anisotrópicas das rochas $\quad 31$

$\begin{array}{ll}\text { 1.4.1. Abordagem } & 31\end{array}$

1.4.2. As propriedades sísmicas $\quad 32$

1.4.2.1. Propriedades elásticas dos cristais $\quad 32$

1.4.2.2. Cálculo das velocidades sísmicas 33

1.4.2.3. Os efeitos da anisotropia sísmica 34

1.4.3. A anisotropia de susceptibilidade magnética (ASM) 35 
Capítulo 2.

Orientações preferenciais da rede medidas através da técnica EBSD e propriedades sísmicas dos eclogitos

"EBSD-measured lattice preferred orientations and seismic properties of eclogites"

2.1. Resumo

Ver artigo no anexo I

Capítulo 3.

Deformação plástica e desenvolvimento das orientações preferenciais da rede nos eclogitos

"Plastic deformation and development of clinopyroxene lattice preferred orientations in eclogites"

3.1. Resumo

Ver artigo no anexo II

OS GRANULITOS

Capítulo 4.

Microestruturas e OPR nos milonitos granulíticos

4.1. Os deslocamentos transpressivos na faixa Ribeira ao sudeste do Brasil 43

4.1.1. Quadro tectônico regional

4.1.2. Zonas de cisalhamento de alta temperatura:

o sistema Além Paraíba-Pádua

4.1.2.1. Localização

4.1.2.2. O perfil de Miracema-Itaocara: as estruturas 50

4.1.2.3. O perfil Miracema-Itaocara: natureza dos afloramentos

e dados de pressão-temperatura $\quad 51$

4.2. Microestruturas e OPR

4.2.1. O quartzo $\quad 59$

4.2.1.1. Estrutura e deformação plástica $\quad 59$

4.2.1.2. Microestruturas: observações 61

4.2.1.3. As OPR medidas 64

4.2.1.4. Microestruturas e OPR do quartzo : discussão 65

4.2.2. Os feldspatos 71

4.2.2.1. Estruturas e deformação plástica

4.2.2.2. Microestruturas :observações 73

4.2.2.3. As OPR medidas 74

4.2.2.4. Microestruturas e OPR dos feldspatos : discussão 77

4.2.3. Os piroxênios, o anfibólio e a biotita $\quad 80$

4.2.3.1. Estrutura e deformação plástica 80

4.2.3.2. Microestruturas :observações $\quad 82$

4.2.3.3. As OPR medidas $\quad 83$ 
4.2.3.4. Microestruturas e OPR dos ortopiroxênios e do anfibólio: discussão 83 4.3. Processos sin- e pós cinemáticos nos milonitos de alta temperatura: discussão e conclusão

\section{Capítulo 5.}

Orientações preferenciais da rede dos óxidos "ilmenita - hematita" $\mathrm{e}$ anisotropia magnética nos milonitos de alta temperatura

"Titanohematite lattice-preferred orientation and magnetic anisotropy in hightemperature mylonites"

5.1. Resumo

Ver artigo no anexo III

\section{Capítulo 6}

Propriedades sísmicas

6.1. Introdução

6.2. As propriedades sísmicas

6.2.1. Monocristais e agregados monofásicos 91

$\begin{array}{ll}\text { 6.2.1.1. O quartzo } & 92\end{array}$

6.2.1.2. Oplagioclásio 93

6.2.1.3. O ortopiroxênio 94

6.2.1.4. O anfibólio 94

6.2.1.5. A biotita 95

6.2.2. As amostras $\quad 95$

6.2.2.1. O milonito com hiperstênio e anfibólio (RB607A) 96

6.2.2.2. O gnaisse enderbitico (RB559) 97

6.2.2.3. O milonito com anfibólio (RB609A) 98

6.2.2.4. O milonito de composição granítica (RB609C) 98

6.2.2.5. O milonito com hiperstênio (RB540) 99

6.3. Refletividade sísmica 104

6.4. Contribuição dos milonitos à defasagem das ondas $S \quad 107$

$\begin{array}{ll}\text { 6.5. Conclusão } & 110\end{array}$

CONCLUSÕES 112

REFERÊNCIAS BIBLIOGRÁFICAS 118

ANEXOS

ANEXO I. EBSD-measured lattice preferred orientation and seismic properties of eclogites

1. Introduction

2. Geological setting and petrology of samples 136

2.1. Alpe Arami eclogites (Alps)

2.2. Mt Mucrone eclogites (Alps) 136

2.3. Monviso eclogites (Alps) 137

$\begin{array}{ll}2.4 \text { Siviez-Mischabel nappe eclogites (Alps) } & 137\end{array}$

2.5. Bergen Arc eclogites (Norway) 138

2.6. Western Gneiss Region eclogites (Norway) 139

2.7. Gourma eclogites (Mali) 139 
2.8. Sulu eclogites (eastern China) 139

3. EBSD measurements 140

3.1. Experimental setup and indexing procedure $\quad 140$

3.2. Omphacite lattice preferred orientations 141

3.3. Omphacite LPO significance 145

4. Eclogite seismic properties $\quad 146$

4.1. Seismic properties calculation $\quad 146$

$\begin{array}{ll}\text { 4.2. Eclogite seismic properties } & 147\end{array}$

4.3. Comparison between calculated and measured eclogite seismic velocities 149

5. Discussion

6. Conclusion 151

ANEXO II. Plastic deformation and development of clinopyroxene lattice preferred orientations in eclogites

1. Introduction

2. Naturally deformed omphacite $\quad 157$

2.1. Previous data on clinopyroxene LPO 157

2.2. Measured omphacite LPO 158

3. Viscoplastic self-consistent modeling of omphacite LPO 158

3.1. Simple shear and pure shear 161

3.2. Axial shortening 163

3.3. Transpression and transtension $\quad 163$

3.4. Slip systems activity 163

4. Discussion $\quad 165$

5. Conclusion $\quad 166$

ANEXO III. Titanohematite lattice preferred orientation and magnetic $\begin{array}{ll}\text { anisotropy in high-temperature mylonites } & 168\end{array}$

$\begin{array}{ll}\text { 1. Introduction } & 169\end{array}$

2. Geological setting and petrology of samples 170

$\begin{array}{lr}\text { 3. Magnetic measurements } & 172\end{array}$

3.1. Magnetic mineralogy and rock magnetism $\quad 172$

3.2.Anisotropy of low-field magnetic susceptibility (AMS) and magnetic fabrics 173

3.3. Anisotropy of remanent magnetization (ARM) and ARM fabrics 174

$\begin{array}{ll}\text { 4. Crystallographic fabric } & 176\end{array}$

4.1. LPO determination $\quad 176$

$\begin{array}{ll}\text { 4.2. Results } & 177\end{array}$

5. Comparison between magnetic and crystallographic fabric $\quad 178$

6. Kinematic analysis and fabric strengths 179

$\begin{array}{lr}\text { 7. Conclusion } & 182\end{array}$

APENNDICES

APÊNDICE I. As OPR da granada nos eclogitos $\quad \underline{186}$

APÊNDICE II. Dados de petrologia e composição química dos granulitos 188 


\section{INTRODUÇÃO GERAL}

Reconstruir a evolução dos grandes eventos tectônicos como as orogêneses por exemplo, necessita compreender os mecanismos da deformação das rochas e conhecer a estrutura da crosta profunda. $O$ estudo das microestruturas associado com a deformação das rochas começou no fim do século XIX. Entre os trabalhos precursores, destaca-se os de Mügge $(1883,1898)$ sobre a geminação mecânica da calcita e as relações entre a estrutura cristalográfica e a deformação para os diferentes minerais. No século passado, o desenvolvimento dos trabalhos experimentais acerca da deformação em monocristais e/ou agregados monofásicos permitiu entender melhor os mecanismos de deformação ativos nos minerais. Com os experimentos em laboratório e os avanços realizados nas ciências dos materiais (a metalurgia principalmente), tornou-se possível decifrar a mensagem contida na microestrutura das rochas.

O conhecimento da estrutura interna da litosfera progrediu consideravelmente com o desenvolvimento da sismologia. As técnicas de sísmica de reflexão e refração permitem a obtenção de imagens cada vez mais precisas da estrutura da crosta. Os métodos de estudo sobre a anisotropia sísmica fornecem informações valiosas da estrutura tectônica e assim sobre os processos de deformação na litosfera (Silver e Chan, 1988; Savage et al., 1989; Vauchez e Nicolas, 1991; Barruol et al., 1997). Outras técnicas geofísicas como, por exemplo, os estudos de anisotropia magnética, estão sendo cada vez mais empregadas como complemento dos estudos sismológicos (p. ex., Borradaile, 1999). A interpretação dos resultados obtidos por estas técnicas apóia-se sobre o conhecimento das propriedades físicas das rochas, de seu relacionamento com a deformação e de sua variação com a profundidade.

Os problemas abordados neste trabalho referem-se à deformação e às propriedades físicas anisotrópicas dos eclogitos (rochas metamórficas de alta e ultra-alta temperatura) e dos granulitos (rochas metamórficas de alta temperatura). Alguns pontos fundamentais serviram de base para as nossas investigações : 
- Quais são os minerais susceptíveis de fornecer informações sobre a deformação ocorrida nos eclogitos e granulitos (forma do elipsóide de deformação, existência de um componente de cisalhamento...)?

- Quais são os mecanismos intracristalinos ativados nos principais minerais durante e após a deformação?

- Quais são as modificações das propriedades físicas (em particular as propriedades da anisotropia sísmica) oriundas da deformação dos corpos eclogíticos e granulíticos ?

- Quais são as características apresentadas pelas reflexões sísmicas devidas a presença destas rochas na crosta e qual é o papel da anisotropia sobre esta refletividade sísmica?

Os problemas acima mencionados foram abordados através de uma análise das microestruturas (forma dos grãos, arranjo dos grãos entre eles, sub estruturas...) e da medida das orientações preferenciais da rede cristalina (OPR) dos minerais. Este enfoque é particularmente interessante para as rochas de alto grau cuja deformação é geralmente associada com os grandes eventos tectônicos que afetam a crosta em profundidade. A deformação das rochas gera uma orientação preferencial da rede cristalina (OPR) dos minerais susceptíveis de trazer informações sobre os mecanismos intracristalinos ativos durante esta deformação (Nicolas e Poirier, 1976; Wenk e Christie, 1991) assim como o regime deformacional (coaxialidade ou não-coaxialidade da deformação, sentido do cisalhamento...). Além disso, a determinação das orientações preferenciais cristalográficas completas, isto é, de todos os eixos cristalográficos, permite o cálculo das propriedades físicas das rochas sob diferentes condições de pressão e temperatura (Mainprice e Nicolas, 1989; Siegesmund et al., 1991).

Os trabalhos acerca das microestruturas e dos mecanismos de deformação dos eclogitos e dos granulitos são escassos em comparação com os estudos realizados em rochas monominerálicas como os quartzitos, e rochas poliminerálicas de fácies intermediário (fácies xisto verde ou anfibolito). Nas rochas de alto grau, a aquisição e a interpretação dos dados é difícil e trabalhosa. A medida da OPR das principais fases minerais dos eclogitos, através da técnica clássica da platina universal, é muito restrita. A granada é opticamente isotrópica e para o clinopiroxênio de alta pressão (onfacita) de simetria monoclínica é necessário medir uma clivagem a fim de determinar a orientação dos outros eixos; no entanto as clivagens nem sempre são observadas ou estão presentes. A leitura e a interpretação das microestruturas 
muitas vezes tornam-se complexas devido a um retrometamorfismo acentuado que pode afetar as amostras. Nos granulitos, o plagioclásio muitas vezes é o constituinte principal dessas rochas. Devido a sua simetria muito baixa (triclínica), a OPR deste mineral é muito difícil de ser medida através da platina universal. A textura granoblástica típica dos granulitos complica a interpretação das microestruturas; elas foram muitas vezes interpretadas como "nãodeformadas", ou como resultando de uma intensa recristalização.

As orientações dos cristais que compõem os eclogitos e os granulitos, foram medidas empregando-se uma nova técnica que analisa as figuras de difração dos elétrons retroespalhados gerados em um microscópio eletrônico de varredura (Electron BackScattered Diffraction technique). Esta técnica e os mecanismos de deformação intracristalinos que geram as orientações preferenciais dos cristais são descritos no primeiro capítulo deste trabalho. Dois outros métodos, que também permitem a determinação das propriedades anisotrópicas das rochas são lembrados. O primeiro tem como base o cálculo das propriedades sísmicas e o segundo, a medida das propriedades de susceptibilidade magnética.

As relações entre microestruturas, mecanismos de deformação e propriedades físicas anisotrópicas dos eclogitos são apresentadas através de duas publicações. A primeira, publicada na revista "Tectonophysics" (Capítulo 2 da tese - anexo I) trata do problema da assinatura sísmica de corpos eclogíticos incorporados na crosta terrestre. A presença de eclogitos nos domínios orogênicos é geralmente associada com a ascensão rápida de uma porção de crosta previamente arrastada em grande profundidade pela subdução. Quais são as reflexões sísmicas associadas com a presença de corpos eclogíticos na litosfera continental ? Qual é o papel da anisotropia sísmica sobre a refletividade das diferentes interfaces litológicas : eclogito - outras rochas da crosta, eclogito - rochas do manto ? Para tentar responder a estas primeiras perguntas, as propriedades sísmicas de amostras eclogíticas foram calculadas a partir da orientação preferencial da rede das fases minerais principais (onfacita e granada). A caracterização das OPR da onfacita e da granada foi realizada em eclogitos oriundos de domínios orogênicos de idade e evolução geodinâmica diferentes: os Alpes, a faixa caledoniana na Noruega, o cinturão de idade panafricana no Mali e a faixa SuluDabishan na China.

A segunda publicação, na revista "Journal of Structural Geology" (Capítulo 3 da tese - anexo II) trata das relações entre a deformação plástica e o desenvolvimento das OPR 
dos clinopiroxênios. Nos eclogitos, a interpretação das OPR da onfacita pode auxiliar na compreensão dos processos tectônicos ativos sob condições de alta pressão. Porém, para os clinopiroxênios, as relações entre os mecanismos da deformação plástica e o desenvolvimento das OPR eram ainda mal entendidas. De fato, para o clinopiroxênio, as interpretações das OPR e das observações realizadas ao microscópio eletrônico de transmissão para a identificação de defeitos cristalinos em termos de mecanismos de deformação eram aparentemente divergentes (ver Godard e Van Roermund, 1995 para discussão). Este problema foi abordado com a realização de simulações numéricas sobre o desenvolvimento das OPR da onfacita em resposta a uma deformação plástica acomodada por um deslizamento intracristalino ("dislocation glide").

O estudo dos granulitos focalizou-se sobre uma zona milonítica ampla, que aflora na faixa Ribeira neoproterozoíca no sudeste do Brasil. A formação destas rochas intensamente deformadas é associada com a ativação de zonas de cisalhamento que afloram ao longo da faixa sobre várias centenas de quilômetros. Estas zonas de cisalhamento de escala litosférica tornam possível o estudo dos processos de deformação associados com a milonitização sob fácies granulítico. Além disso, elas permitem estudar as propriedades sísmicas associadas com tais estruturas na crosta continental profunda.

No capítulo 4 são apresentadas as microestruturas e as OPR de rochas deformadas sob condições de alta temperatura, coletadas ao longo de um perfil transversal a uma rede de zonas de cisalhamento de grande escala (zonas de cisalhamento de Além Paraíba-Pádua; Egydio-Silva et al., 2002). O estudo das relações entre as microestruturas e as OPR dos constituintes mineralógicos principais dos granulitos permitiu a discussão dos processos sin- e pós- tectônicos em milonitos de alta temperatura.

$\mathrm{Na}$ busca por minerais portadores de informações sobre a deformação sofrida pela rocha, nossa atenção focalizou-se sobre os óxidos de Fe-Ti. Estes minerais são freqüentemente descritos nos granulitos, mas o número de trabalhos acerca das microestruturas e dos mecanismos de deformação em óxidos de $\mathrm{Fe}$-Ti é relativamente restrito (p. ex., Agar e Lloyd, 1997; Lagoeiro, 1998a,b). Além disso, estes minerais são uma das principais fontes da anisotropia de susceptibilidade magnética (ASM) das rochas. A medida desta anisotropia magnética é particularmente interessante para os granulitos cujas estruturas tectônicas (foliação e lineação) são, muitas vezes, dificilmente observáveis (p. ex., Halls e 
Hanes, 1999; Raposo e Egydio-Silva, 2001). Para investigar as relações entre a deformação e a anisotropia magnética, foram comparadas as OPR dos principais óxidos de Fe-Ti e das fases silicatadas, a trama magnética (ASM) e os eixos da deformação finita, de cinco milonitos granulíticos. Os resultados são apresentados através de uma publicação na revista "Earth and Planetary Science Letters" (Capítulo 5 da tese - anexo III).

Finalmente, o Capítulo 6 tem como objetivo abordar dois problemas complementares : i) o papel da milonitização sobre a refletividade das zonas de cisalhamento na base da crosta, e ii) a contribuição da crosta na defasagem das ondas de cisalhamento nos domínios de transcorrências litosféricas. Para isso, foram calculadas as propriedades sísmicas de quatro milonitos e de um gnaisse enderbítico, coletados ao longo do perfil transversal às zonas de cisalhamento de Além Paraíba-Pádua. 


\section{Capítulo 1.}

\section{Da deformação às propriedades físicas anisotrópicas}

\subsection{Abordagem experimental da deformação plástica}

Um cristal ou um agregado de cristais submetido a um esforço externo responde a esta solicitação movendo-se ou deformando-se. Uma experiência clássica consiste em submeter uma amostra sob a ação de esforços, em determinadas condições de pressão e de temperatura, visando estudar a resposta do material a tal solicitação. Por exemplo, durante uma compressão, a amostra terá um comportamento reológico característico ilustrado pela Fig. 1.1a.

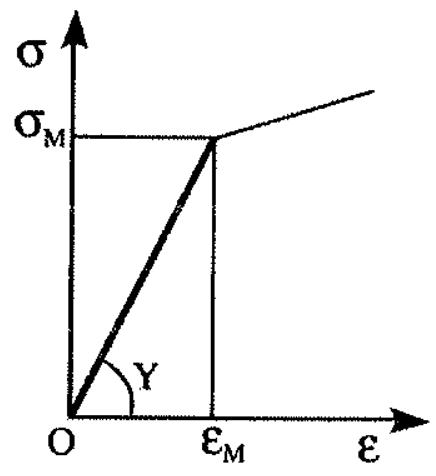

(a)

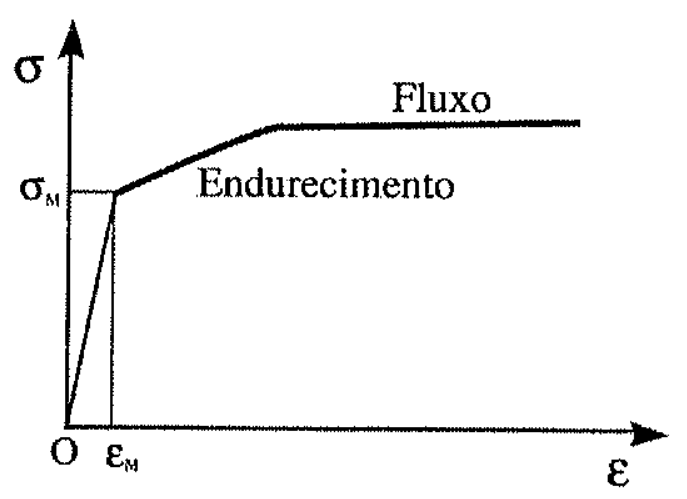

(b)

Fig. 1.1. (a) Deformação de uma rocha em função do esforço $\sigma .0$ traço grosso indica o domínio elástico; (b) Deformação plástica (traço grosso) em função do esforço (segundo Nicolas, 1984).

No início da experiência, a resposta do material corresponde a uma linha reta. A amostra deforma-se elasticamente e o esforço necessário aumenta linearmente com a deformação (ou com o tempo). A deformação elástica é reversível e exprime-se pela relação $\sigma=$ Y $\varepsilon$ na qual $\sigma$ é o esforço e Y é o módulo de Young. Quando o esforço atinge o limite elástico $\left(\sigma_{\mathrm{M}}\right)$, a deformação deixa de ser reversível, ela torna-se plástica e continua no tempo. A Fig. 1.1b mostra uma curva de deformação plástica com uma inclinação positiva, após o limite elástico. A partir desse ponto, para aumentar a deformação, é necessário maiores esforços. Este fenômeno chama-se endurecimento associado à deformação ("strain hardening"). Trata-se de um processo muito conhecido na metalurgia, onde, desde 
antigamente, malha-se o metal visando o seu endurecimento, tornando-o assim mais resistente.

Uma maneira simples para descrever o comportamento de um material deformado é através da expressão que relaciona a taxa de deformação $(\dot{\varepsilon})$ em função do esforço aplicado. Esta taxa ou velocidade de deformação que corresponde à derivada da deformação em função do tempo, pode ser expressa pela equação genérica : $\dot{\varepsilon}=\alpha \sigma^{\mathrm{n}}$ para $\mathrm{T}, \mathrm{P}=$ cte; $\alpha$ sendo uma constante própria do material e n o expoente do esforço, o qual traduz a sensibilidade da velocidade de deformação ao esforço. Por exemplo, um valor de $n$ igual a 1 caracteriza um fluxo newtoniano. Quando $\dot{\varepsilon}$ é constante $\operatorname{com} \sigma, \mathrm{T}, \mathrm{P}=$ cte, fala-se de fluxo estacionário.

\subsection{Mecanismos da deformação plástica}

A resposta macroscópica à deformação é de movimentos na escala microscópica tais como:

- o movimento das discordâncias (em inglês: "dislocations")

- o transporte de matéria por difusão assistida ou não por fluídos

Neste capítulo são apresentados sumariamente os mecanismos associados a esses dois processos deformacionais, com ênfase nos mecanismos intractistalinos que são os principais responsáveis pelas modificações da microestrutura das rochas da crosta média, inferior e do manto. Os mecanismos de baixa temperatura como o fluxo cataclástico não são abordados. Entretanto, uma descrição dos diferentes mecanismos da deformação plástica pode ser encontrado nas obras de síntese de Hobbs et al., 1976; Nicolas et Poirier, 1976; Nicolas, 1984; Poirier 1985 que serviram de orientação para a redação desta seção.

\subsubsection{As discordâncias}

As propriedades plásticas dos sólidos cristalinos são determinadas essencialmente pelos defeitos que apresenta o cristal em relação a sua estrutura ideal. Tais defeitos podem ser pontuais, lineares ou planares. Sob o efeito de um esforço aplicado, os defeitos lineares, chamados discordâncias, provocarão uma deformação permanente do cristal. Esta deformação ocorre através do cisalhamento da rede ao longo de planos cristalográficos favoráveis, em 
uma determinada direção cristalográfica. Quando a discordância houver atravessado todo o cristal, ele terá sido submetido à deformação plástica mínima de uma distância inter-atômica em um plano inteiro de deslizamento. Esta distância é denominada vetor de Burgers. A deformação plástica mínima pode-se efetuar de duas maneiras: a primeira traduz-se por um movimento das discordâncias paralelamente ao cisalhamento induzido no cristal, e a segunda traduz se por um movimento perpendicular à direção de cisalhamento do cristal. A estes dois deslizamentos elementares são associados dois tipos de discordância: a discordância em cunha ("edge dislocation") e a discordância helicoidal ("screw dislocation"). A linha que define o limite entre porções do cristal com ou sem deslizamento é chamada de linha de discordância ("dislocation line"), (Fig. 1.2a).

Os defeitos lineares podem formar laços de discordância fechados ("dislocation loops") constituídos de discordâncias em cunha e helicoidais de sinais opostos (Fig. 1.2b). O movimento deste laço de discordância fechado gera um cisalhamento definido pelo plano deste laço e uma direção de cisalhamento paralela à discordância helicoidal.

(a)

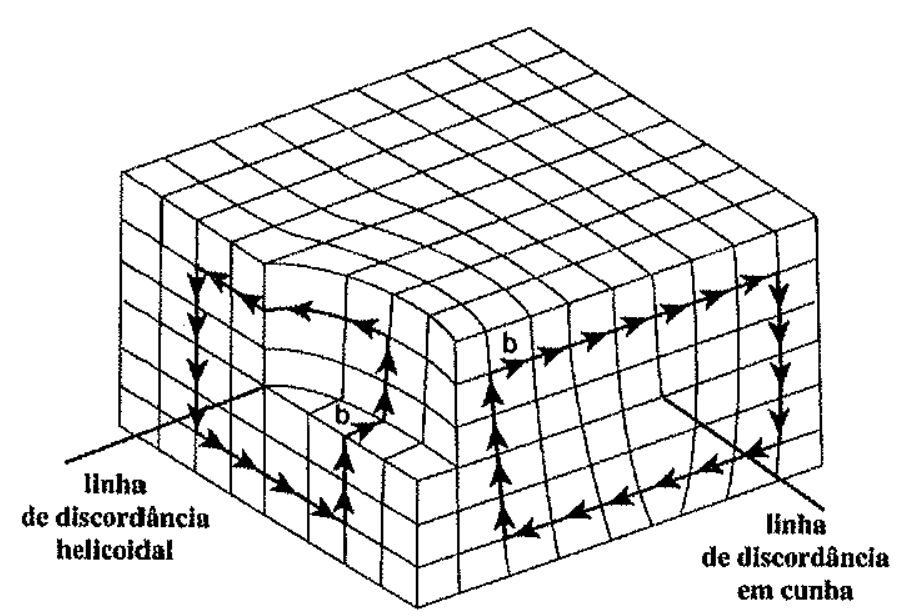

(b)

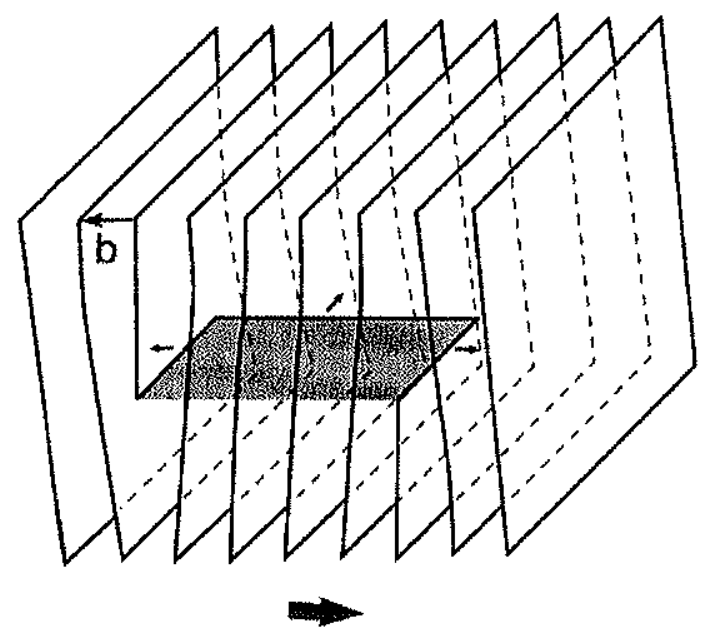

Fig. 1.2. (a) $O$ vetor de Burgers b das discordâncias em cunha e helicoidal; (b) Semi-laço de discordância em um cristal esquematizado através de seus planos reticulares (verticais). A propagação é indicada pelas pequenas setas. b é o vetor de Burgers (segundo Hobbs et al., 1976).

A deformação pode ser acomodada por um jogo de vários sistemas de deslizamento (plano, direção). Os sistemas preferencialmente ativados são os que consomem menos energia, para determinadas condições de pressão e temperatura. Assim, os sistemas de deslizamento favorecidos são aqueles cujos planos de deslizamento são paralelos a um plano reticular denso ou aqueles que não rompem ligações fortes ou ainda aqueles cujas direções apresentam o vetor de Burgers mais curto. Além do deslizamento, as discordâncias podem mover-se por "saltos" de discordâncias ("dislocation climb"). Estes saltos permitem que uma 
discordância em cunha desloque-se em um plano normal ao seu plano de deslizamento, por acréscimo ou perda de matéria no limite do semi-plano suplementar (troca átomo-lacuna). Os saltos de discordâncias colocam em jogo a difusão, que é um mecanismo ativado termicamente. Através de deslizamento e subida associados, as discordâncias tendem a se organizar em paredes de discordância (igualmente chamadas paredes de poligonização) e irão delimitar zonas do cristal chamadas de subgrãos. A multiplicidade de tais paredes no cristal deformado vai provocar rotações da rede cristalina, produzindo às extinções ondulantes observáveis ao microscópio óptico. O mecanismo de deslizamento de discordância com os saltos é conhecido como fluxo de discordâncias (ou fluxo Wertman, em inglês: "dislocation creep").

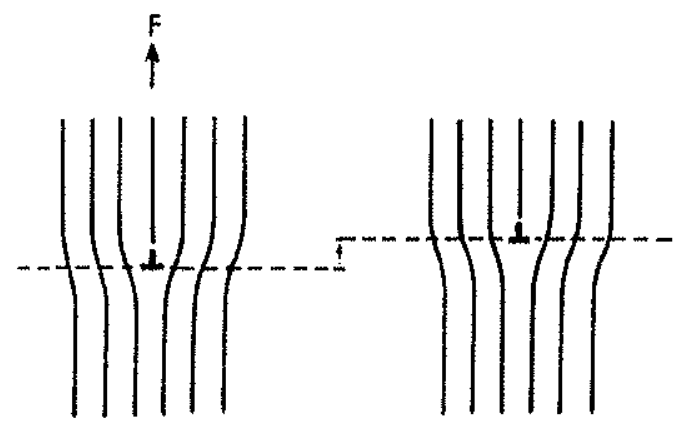

Fig. 1.3. Saltos de discordâncias em cunha sob o efeito de uma força F (segundo Nicolas e Poirier, 1976).

\subsubsection{A recuperação e a recristalização dinâmica : os mecanismos auxiliares do deslizamento}

Com a deformação, a densidade das discordâncias tende a aumentar, e uma grande proporção de discordâncias se encontrará bloqueada por obstáculos, por exemplo, as heterogeneidades contidas no cristal. O aumento da densidade de discordâncias causará o endurecimento e um aumento da energia interna do cristal. Mecanismos como a recuperação e a recristalização permitirão diminuir a energia interna do cristal. Estes dois mecanismos são considerados como antagônicos : a baixa de energia interna provocada por um destes dois mecanismos faz com que o segundo seja dificilmente passível de ser ativado.

Contrariamente à recristalização, a recuperação não coloca em jogo o movimento dos limites de grão (Urai et al., 1986). Este processo mobiliza o salto das discordâncias que vão se dispor em configuração de baixa energia formando as paredes de discordância. 
A evolução da recristalização está associada a diferentes tipos de energia motriz, que são: a energia de deformação elástica devida à presença de defeitos no cristal, a energia de superfície do cristal e a energia-livre química. A recristalização que se produz ao mesmo tempo que a deformação chama-se recristalização dinâmica (ou sintectônica). A recristalização dinâmica, que conduz a uma diminuição da energia de deformação elástica, procede segundo dois grandes mecanismos:

- a recristalização através da rotação dos subgrãos (ou recristalização in situ). A deformação é acompanhada pela multiplicação das paredes de discordâncias, que provoca uma rotação da rede. A partir de uma certa densidade de discordâncias acumulada na parede, os subgrãos se individualizarão por rotação progressiva (até $10-15^{\circ}$ ) e formarão grãos recristalizados (neoblastos) adjacentes ao cristal de origem (porfiroclasto).

- a recristalização por nucleação e migração dos limites de grão. Sob o efeito da deformação, germes cristalinos (nuclei) de baixa energia formam-se no seio dos porfiroclastos e desenvolvem-se por migração dos limites. Este mecanismo de nucleação ainda é muito discutido, pois poucas microestruturas colocam em evidência a formação dos nuclei. Em compensação, microestruturas associadas a mecanismos de germinação nos limites dos grãos ("bulging") são frequentemente observadas. As microestruturas associadas a estes mecanismos são caracterizadas por coroas de neoblastos em torno dos porfiroclastos. Com o aumento da temperatura, a migração é favorecida e o tamanho dos neoblastos aumenta (Nicolas, 1984).

\subsubsection{A migração dos limites de grão e o crescimento dos grãos}

A alta temperatura, a difusão é favorecida e os pequenos grãos, assim como os grandes grãos, podem aumentar. Os motores do crescimento são o contraste de energia interna e de energia da superfície. Esta última é inversamente proporcional ao diâmetro dos grãos. Com o aumento, a curvatura do limite diminui, o limite de grão toma uma forma poligonal e sua energia diminui. Durante a deformação, este mecanismo, que permite a redução da energia do grão, faz concorrência aos outros processos, como a recristalização pela rotação dos subgrãos. Em compensação, após a deformação, este mecanismo de migração dos limites de grão e de crescimento pode se exprimir plenamente, sobretudo a alta temperatura (p. ex., Bons e Urai, 1992). Quando a deformação da rocha cessa, os agregados cristalinos não atingiram necessariamente seu estado de mais baixa energia, mesmo se a restauração e a recristalização 
durante a deformação foram consideráveis. Os cristais ainda podem conter discordâncias isoladas ou paredes de discordância. Se as condições térmicas são relativamente elevadas quando a deformação cessa, ou se há água ao longo dos limites de grão, a migração dos limites e o crescimento dos grãos continuarão até que o agregado atinja seu estado de energia interna mínima. O crescimento dos grãos cuja energia interna é menor como os grande grãos com poucos defeitos vai ser favorecido. Este processo de pós-deformação é chamado recristalização estática. Em metalurgia, o termo "annealing" indica o processo de restauração e de recristalização estática provocada pelo aquecimento de um material precedentemente deformado malhado. Este termo também é utilizado para a interpretação das microsestruturas nas Geociências (p. ex., Green, 1967).

\subsection{4. $O$ fluxo por difusão e a superplasticidade}

A uma temperatura muito elevada, mas abaixo da temperatura de fusão, a deformação pode intervir através do transporte de matéria por difusão entre as superfícies, sem que haja intervenção de discordâncias. Há dois grandes tipos de fluxo por difusão: o fluxo NabarroHerring e o fluxo Coble. O primeiro opera por difusão orientada dos átomos através da rede cristalina; o segundo opera por difusão orientada dos átomos ao longo dos limites de grão, sob o efeito de um esforço.

A uma temperatura muito elevada, os agregados constituídos de grãos de tamanho muito pequeno $(<10 \mu \mathrm{m})$ poderiam se deformar por deslizamento ao longo dos limites, sem que a estrutura do limite seja alterada (Poirier, 1985). O deslizamento ao nível dos limites poderia ser associado a um mecanismo secundário que permitiria reabsorver os obstáculos ao deslizamento e minimizar os "vazios", assegurando a coesão entre os cristais. Segundo o modelo de Ashby e Verral (1973), o mecanismo secundário que acompanha o deslizamento ao nível dos limites de grão é a difusão (Fig. 1.4). O deslizamento ao nível dos limites conduz a um comportamento assimilável à superplasticidade, ou seja, um comportamento caracterizado por um não-endurecimento durante a deformação. O material pode suportar alongamentos consideráveis sem que apareça estricção que conduza à ruptura. Nas rochas, a intervenção do deslizamento ao nível dos limites foi demonstrada para amostras de calcário experimentalmente deformadas (Schmid et al., 1977). Para milonitos de grãos finos 
naturalmente deformados, um possível comportamento superplástico foi evocado por diferente autores (p. ex., Boullier e Guegen, 1975; Vauchez, 1980).<smiles>C1CC2CCC3CCCC4CCC(C1)C2C34</smiles>
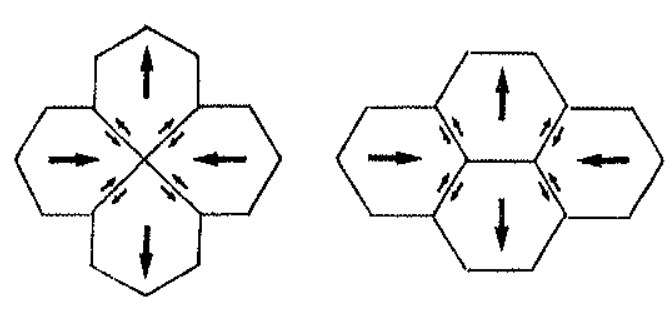

Fig. 1.4. Rearranjo dos grãos durante um fluxo superplástico por associação de deslizamento ao nível dos limites e difusão em superfície (segundo Ashby e Verral, 1973)

\subsection{Deformação plástica e desenvolvimento das orientações preferenciais da rede}

Uma das consequências da deformação intracristalina é o desenvolvimento de uma orientação preferencial da rede cristalográfica (OPR). Tendo em vista que ela está diretamente ligada aos processos microscópicos da deformação plástica, esta OPR é uma fonte potencial de informação sobre:

- os mecanismos intracristalinos, e particularmente a atividade dos sistemas de deslizamento dominante em relação com as condições físicas (particularmente térmicas), - o regime e a cinemática da deformação.

\subsubsection{Deslizamento, geminação e desenvolvimento das OPR}

Schmidt e Boas (1950) mostraram que um dado sistema de deslizamento é ativado quando o esforço cisalhante resultante $\left(\sigma_{\mathrm{R}}\right)$ no plano de deslizamento, na direção de deslizamento atinge um valor crítico $\left(\sigma_{\mathrm{c}}\right)$. Este esforço cisalhante resultante crítico ("critical resolved shear stress, ou CRSS") é uma característica intrínseca a cada sistema de deslizamento. Como mostra a Fig. 1.5, o esforço cisalhante resultante pode ser expresso a partir das relações angulares entre o eixo de compressão, a normal do plano de cisalhamento e a direção de cisalhamento. 


$$
\sigma_{\mathrm{R}}=\left(\mathrm{F} / \mathrm{A}_{0}\right) \cos \psi \cdot \cos \lambda=\left(\mathrm{F} / \mathrm{A}_{0}\right) \mathrm{S}
$$

onde $\psi$ é o ângulo entre a normal do plano de deslizamento e o eixo de compressão, e $\lambda$ o ângulo entre o eixo de compressão e a direção de deslizamento.

A relação $\cos \psi \cdot \cos \lambda$ é denominada fator de Schmidt (S). Para um sistema de deslizamento potencial e para uma dada direção, o valor do fator de Schmidt, o qual é estabelecido experimentalmente, é fortemente dependente das condições térmicas da deformação. O sistema de deslizamento tendo o fator de Schmidt mais elevado é ativado. Para uma deformação coaxial, o fator de Schmidt máximo tem um valor de $0.5\left(\psi=45^{\circ}\right)$.

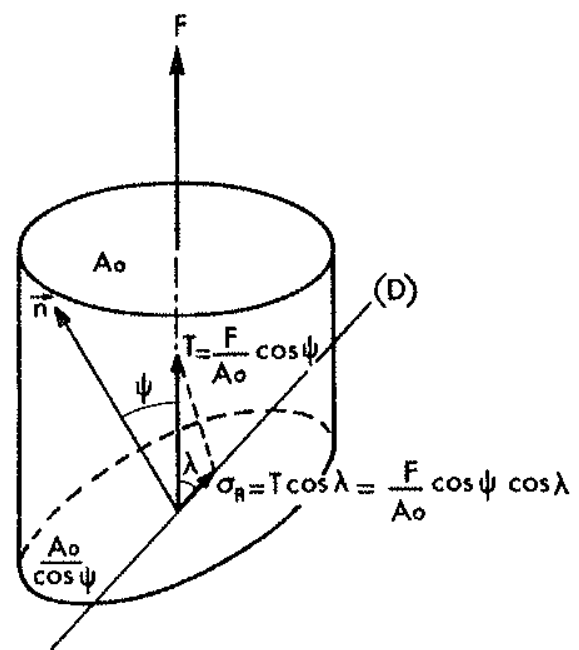

Fig. 1.5. Esforço cisalhante resultante $\left(\sigma_{R}\right)$. n é a normal do plano de deslizamento e $D$ a direção de deslizamento. F é o eixo de compressão de um monocristal em forma de cilindro (segundo Nicolas $e$ Poirier, 1976).

Geralmente vários sistemas de deslizamento podem ser ativados nos minerais que constituem as rochas. A ativação de mais de cinco sistemas de deslizamento independentes é necessária para que a deformação seja homogênea (Von Mises, 1928). Tendo em vista sua pouca simetria, a maioria dos minerais não possui cinco sistemas independentes, particularmente durante uma deformação a baixa temperatura. Outros mecanismos como a geminação vão auxiliar o deslizamento e aumentam o grau de liberdade do mineral (Nazé et al. (1987) para o ortopiroxênio). 


\subsubsection{Interpretação cinemática das $O P R$}

A OPR induzida por estes mecanismos intracristalinos pode apresentar uma pequena obliquidade em relação ao referencial estrutural (lineação e foliação) definido pela orientação preferencial de forma dos minerais. A lineação é definida pela direção de alongamento médio dos grãos e a foliação pelo plano de achatamento médio dos grãos. Esta assimetria entre a OPR e os eixos tectônicos é frequentemente observada nos milonitos das zonas de cisalhamento; ela é associada a uma não-coaxialidade do regime de deformação e como um indicador do sentido de cisalhamento (Nicolas, 1972 et al.; Bouchez et al., 1983). Numerosos modelos do desenvolvimento das fábricas (p. ex., Etchecopar et Vasseur, 1987) e trabalhos de deformação experimental (p. ex., Bouchez et Duval, 1982) permitiram estabelecer um método de análise cinemática para rochas afetadas por uma deformação plástica homogênea. Este método apóia-se no princípio da ativação de um sistema de deslizamento dominante nos minerais das rochas deformadas e em duas regras baseadas (Nicolas, 1984) :

1) na convergência entre as orientações preferenciais do plano e da direção de deslizamento dominante e o plano e a direção do fluxo plástico,

2) nas relações entre a orientação preferencial dos sistemas de deslizamento e as direções da deformação finita que informam sobre o regime da deformação plástica.

No caso de uma deformação coaxial, as direções de deslizamento e da deformação finita tornam-se paralelas enquanto que no caso de uma deformação não coaxial (cisalhamento simples) uma obliquidade permanece. O sentido de rotação para passar de um referencial ao outro permite determinar o sentido de cisalhamento (Fig. 1.6).

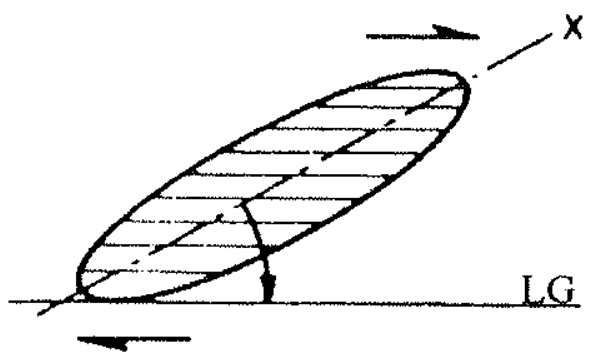

$-\mathbf{a}$

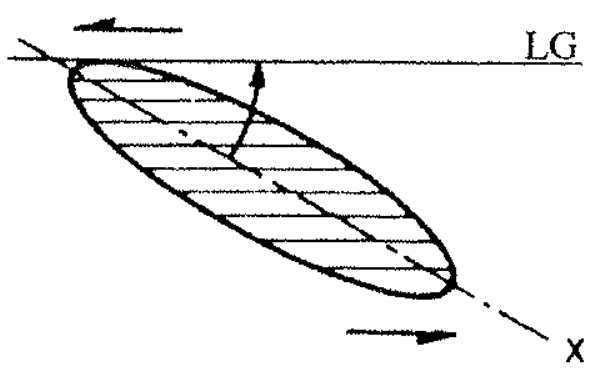

$-b$.

Fig. 1.6. Análise cinemática: (a) cisalhamento dextral; (b) cisalhamento sinestral. LG: direção de deslizamento, X: a lineação (segundo Bouchez et al., 1983).

Este método de análise cinemática fornece resultados confiáveis, particularmente para minerais deformados em condições para as quais um sistema de deslizamento é realmente dominante, como a olivina ou o ortopiroxênio. 
A hipótese da ativação de um sistema de deslizamento dominante durante a deformação nem sempre é válida. As experiências de deformação experimental mostram uma dependência da atividade do deslizamento em relação às condições térmicas. A alta temperatura, o número de sistemas de deslizamento que contribuem para a deformação é maior que em deformação mais baixa. A ativação simultânea de sistemas de deslizamento é evidenciada por valores do fator de Schmidt elevados e próximos. Estes diferentes sistemas competirão então entre si, e a predominância de um sistema dependerá de vários parâmetros (simetria cristalográfica, defeitos da rede gerados por uma deformação anterior, anisotropia dos grãos, estado do esforço, ...). Além disso, a literatura fornece exemplos de OPR que são incompatíveis com a ativação do sistema dominante estabelecido pelas análises de microscopia eletrônica. Tal é o caso por exemplo das OPR de olivina dos lherzolitos do maciço do "alpe Arami" (Möckel, 1969) ou, de modo mais geral, das OPR de clinopiroxênio. Uma melhor compreensão do desenvolvimento destas OPR deveria levar em consideração a atividade dos diferentes sistemas de deslizamento que participam da deformação.

Os modelos mais recentes de simulação das OPR têm por princípio a integração do conjunto dos sistemas de deslizamento ativados, bem como do maior número de parâmetros que caracterizam a deformação (ver o texto de síntese de Wenk e Christie, 1991). Nestes modelos de deformação de policristais, o comportamento macroscópico corresponde à média volumétrica dos comportamentos microscópicos. O modelo auto-coerente viscoplástico (VPSC) (Molinari et al., 1987) é um desses modelos recentes. Ele permite levar em consideração a atividade dos diferentes sistemas de deslizamento de um cristal, bem como os valores de resistência ao deslizamento (CRSS) e o expoente $\mathrm{n}$ dos esforços de cada sistema deduzido das análises de deformação experimental. Além disso, este modelo leva em conta os parâmetros cristalográficos (simetria, malha elementar) e das anisotropias macroscópicas e microscópicas (Lebenson et Tomé, 1993). Este tipo de modelo é muito interessante para a análise das OPR pois ele permite relacionar a evolução das OPR, a atividade dos diferentes sistemas de deslizamento ao longo da deformação e o regime da deformação. Um exemplo de utilização do modelo VPSC para a simulação da deformação do clinopiroxênio é apresentado no Capítulo 3 - anexo II.

Um outro processo importante a ser considerado para a interpretação das OPR é o da recristalização. Na verdade, a OPR medida nas rochas naturais é susceptível de ser afetada pela recristalização sin- e/ou pós-tectônica. De uma maneira geral, os processos de recristalização e seu efeito sobre a evolução das OPR ainda são mal conhecidos. Os 
mecanismos de recristalização dependem de um grande número de fatores, em particular, a temperatura, a taxa de deformação, o conteúdo de água (ou a presença de uma segunda fase mineral, Karato, 1988) que poderiam ter uma influência sobre o desenvolvimento das OPR. Porém, os processos de recristalização dinâmica não parecem modificar muito as OPR adquiridas durante a deformação dos grãos (Urai et al., 1986). O efeito do "annealing" sobre a evolução das OPR é mais difícil de avaliar que o efeito da recristalização dinâmica pois a microestrutura da deformação é totalmente obliterada pelos mecanismos de migração nos limites do s; este problema é abordado para o quartzo na seção 4.2.1.4.

Enfim, a análise das microestruturas pode ser dificultada por uma história tectônica complexa, com fases de deformações que se sucedem (zonas poli-orogênicas, reativações tardias de falhas nas zonas miloníticas,...) e que podem estar na origem de microestruturas que se sucedem. Por exemplo, nas zonas miloníticas, microestruturas associadas à um evento tardio, geralmente retrometamórfico, são frequentemente descritas. Elas se sobrepõem à trama anterior formada no decorrer da fase de deformação principal da orogênese e podem impedir ou perturbar o estudo. A interpretação das OPR deve permanecer associada ao estudo das estruturas microscópicas e de escala regional.

\subsubsection{A medida das OPR: a técnica EBSD}

1.3.3.1. Principais instrumentos e técnicas de medida das OPR: a platina universal, os goniômetros e a microscopia eletrônica de varredura

A técnica mais antiga para a medida das OPR é a platina universal de 4 ou 5 eixos acoplada a um microscópio óptico. A determinação das orientações cristalográficas é baseada nas relações existentes entre os eixos ópticos e cristalográficos do mineral estudado. Esta técnica de aplicação relativamente simples apresenta entretanto grandes limitações:

- os minerais opticamente isotrópicos (simetria cúbica) como a granada ou a magnetita não podem ser medidos

- para os minerais uniaxiais como o quartzo ou a ilmenita, somente o eixo-[0001] ou eixo-c pode ser medido 
- os minerais de baixa simetria cristalina necessitam da medida dos eixos ópticos $(\mathrm{Ng}, \mathrm{Nm}$, $\mathrm{Np}$ ) e de um plano suplementar. Para os minerais monoclínicos, por exemplo os clinopiroxênios, um único eixo óptico corresponde a um eixo cristalográfico e a medida de uma clivagem é necessária para determinar as orientações dos outros eixos cristalográficos por relações geométricas. Para os minerais triclínicos como o plagioclásio, para os quais nenhum eixo óptico corresponde a um eixo cristalográfico, a determinação das orientações cristalográficas passa por um procedimento relativamente complexo (ver por exemplo, Ji et al., 1994; Egydio-Silva e Mainprice, 1999)

- o tamanho dos grãos mensuráveis não pode ser muito pequeno e as medidas são relativamente demoradas e fastidiosas.

As técnicas de goniometria com o goniômetro de textura por difração $X$ (por exemplo para o quartzo, Schmidt e Casey, 1986) ou o goniômetro de textura pela difração neutrônica (por exemplo para o quartzo, Bouchez et al., 1979) não são limitados como a platina universal pelas propriedades ópticas dos minerais. Porém, elas não apresentam uma grande flexibilidade de utilização e não permitem estudar grão por grão em amostras polifásicas.

Nos últimos anos, desenvolveu-se uma técnica de medida das orientações cristalográficas por análise de figuras de difração produzidas $\mathrm{em}$ um microscópio eletrônico de varredura. Tal técnica, usualmente chamada técnica EBSD (Electron BackScattered Diffraction technique), foi utilizada para medir as OPR apresentadas neste trabalho. Outras medidas foram igualmente feitas com a platina de 5 eixos a fim de compará-las com as orientações medidas através do EBSD.

As figuras de difração são formadas por bandas brilhantes (Fig. 1.7a), chamadas "bandas de Kikuchi", numa referência a sua primeira descrição em um microscópio eletrônico de transmissão (MET) por Kikuchi (1928). A partir dos anos 70, a associação de uma câmera de vídeo ao microscópio eletrônico de varredura (MEV) permitiu a captura e o tratamento das figuras de difração em amostras que têm uma superfície relativamente grande (Venables e Harland, 1973). A chegada das câmeras de vídeo de alta sensibilidade e o desenvolvimento dos instrumentos informáticos para auxiliar no tratamento da imagem permitiram o grande desenvolvimento desta técnica, primeiro nas Ciências dos materiais e, já há alguns anos, nas Geociências. 


\subsubsection{Formação das figuras de difração}

O fenômeno de difração dos elétrons retroespalhados e a formação das bandas de Kikuchi são observáveis tanto em microscopia eletrônica de transmissão quanto de varredura. Quando um feixe eletrônico interage com um sólido cristalino, os elétrons são dispersados em todas as direções. Para uma família de planos reticulares (hkl), elétrons serão difratados sem perda de energia cinética. Esta interação elástica que se encontra na origem dos elétrons retroespalhados é regida pela lei de Bragg:

$$
\mathrm{n} \lambda=2 \mathrm{~d}_{\mathrm{hkl}} \sin \theta
$$

onde $\mathrm{n}=$ ordem da reflexão, $\mathrm{d}_{\mathrm{k} k \mathrm{l}}=$ distância reticular (hkl), $\theta=$ ângulo de Bragg e $\lambda=$ comprimento de onda ligada à tensão de aceleração dos elétrons $\left(\mathrm{V}_{0}\right)$ por :

$$
\lambda=\frac{h}{\sqrt{2 \mathrm{movV}_{0}\left(1+\frac{\mathrm{eV}_{0}}{2 \mathrm{moc}^{2}}\right)}}
$$

onde $\mathrm{h}=$ constante de Planck; $\mathrm{m}_{0}=$ massa do elétron; $\mathrm{e}=$ carga do elétron; $c=$ velocidade da luz.

Em três dimensões, as trajetórias dos elétrons que satisfazem as condições de Bragg definem dois cones chamados cones de Kossel (Fig. 1.7b). Dada a energia elevada dos elétrons (e portanto seu curto comprimento de onda), os ângulos de Bragg são pequenos ( $0.5^{\circ}$ ) e a intersecção dos dois cones com uma tela de fósforo faz aparecer um par de linhas paralelas: as linhas de Kikuchi. Tais linhas delimitam uma banda brilhante de largura $2 \theta$ sobre um fundo/ de menos energia formado pelos elétrons espalhados de maneira inelástica e que constituem o ruído. Então, cada banda brilhante resulta da difração dos elétrons em uma família de planos reticulares. Em decorrência da lei de Bragg, a largura das bandas brilhantes é inversamente proporcional à distância inter-reticular. Além disso, os ângulos entre as bandas de Kikuchi correspondem aos ângulos feitos pelas famílias de planos reticulares entre si, e a intersecção entre as bandas representa uma direção cristalográfica. As figuras de difração compostas por bandas de Kikuchi contêm a informação cristalográfica completa do ponto analisado. 
(a)

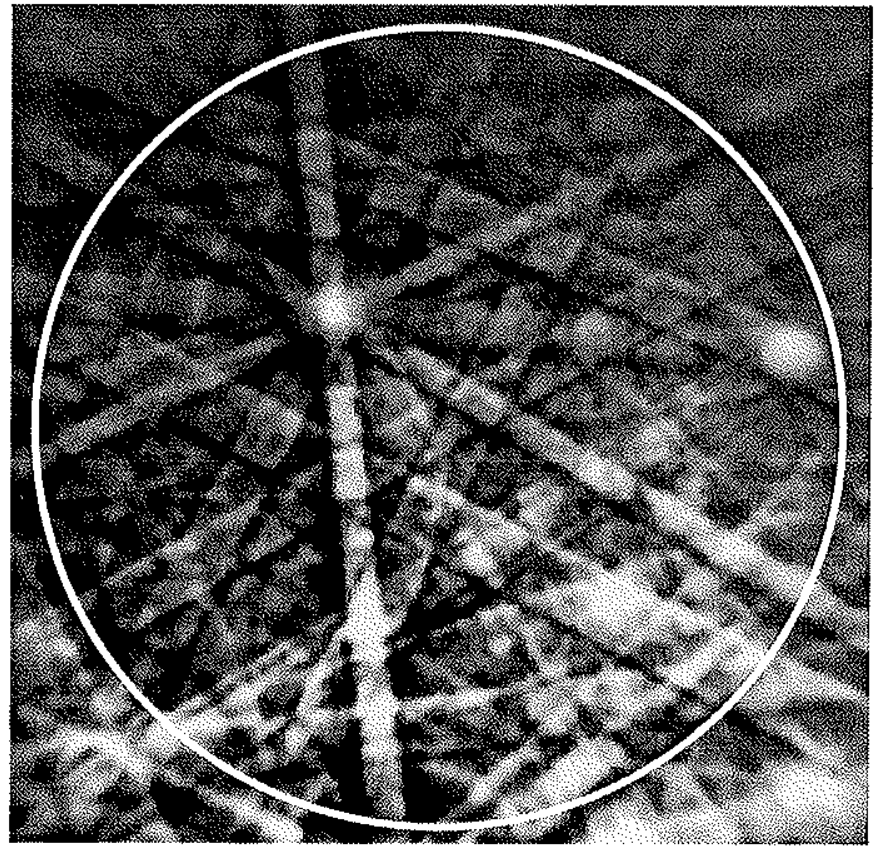

(b)

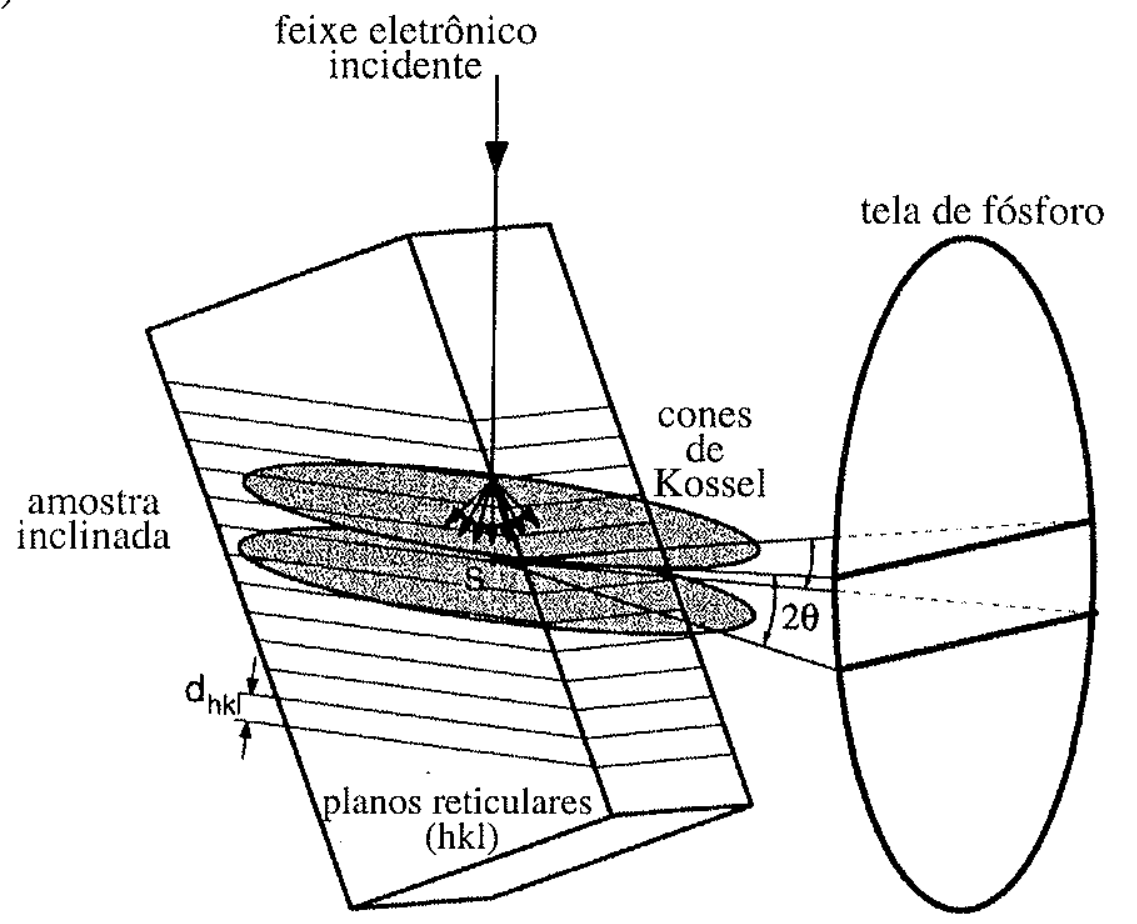

Fig. 1.7. Figuras de difração através da técnica EBSD. (a) Figura de difração de clinopiroxênio; (b) Formação das linhas de Kikuchi devido à difração dos elétrons sobre os planos reticulares (segundo Randle e Engler, 2000). 


\subsubsection{Equipamento, condições de trabalho e preparação das amostras}

O equipamento EBSD utilizado na Universidade de Montpellier II está ilustrado na Fig. 1.8. Na câmara do microscópio do $\mathrm{MEV}$, os elétrons retroespalhados são gerados por um feixe de elétrons focalizado na superfície de uma amostra com 70 graus de inclinação. Esta amostra é constituída por uma lâmina delgada com um polimento particularmente cuidadoso. Uma tela de fósforo colocada no interior da câmara a uns trinta milímetros da amostra recebe os elétrons retroespalhados e emite uma imagem fotônica da figura de difração. No exterior da câmara do $\mathrm{MEV}$, uma câmara de vídeo de alta resolução captura esta imagem fotônica que, em seguida, é tratada de modo a minimizar o ruído. Depois, a imagem de difração digitalizada é indexada para que se obtenha a totalidade de informações cristalográficas (software Channel+, Smidt et Olesen, 1989).

As condições de trabalho são estabelecidas visando otimizar a qualidade das imagens de difração; para a maioria das amostras, elas são equivalentes a:

- inclinação da amostra: $70^{\circ}$,

- distância de trabalho: (distância entre a base da peça polar e a amostra): $40 \mathrm{~mm}$

- tensão de aceleração: $15 \mathrm{keV}$

- intensidade da corrente: $30 \mu \mathrm{A}$.

Para uma boa indexação de tais imagens, é importante que as bandas de Kikuchi apresentem um bom contraste. Este contraste é obtido com um feixe de elétrons muito energético (15-20 keV). Utilizando-se um feixe incidente muito mais energético, a qualidade do contraste deixa de ser assegurada. Isto decorre do fato dos elétrons mais energéticos adquirirem um maior poder de penetração na amostra, aumentando o rú́do devido às interações inelásticas. A inclinação de $70^{\circ}$ da amostra permite limitar a profundidade de interação dos elétrons na estrutura cristalina. As relações entre as variações dos diferentes parâmetros que controlam as condições de trabalho e a qualidade das figuras de difração são descritas em Randle e Engler (2000). 
(a)

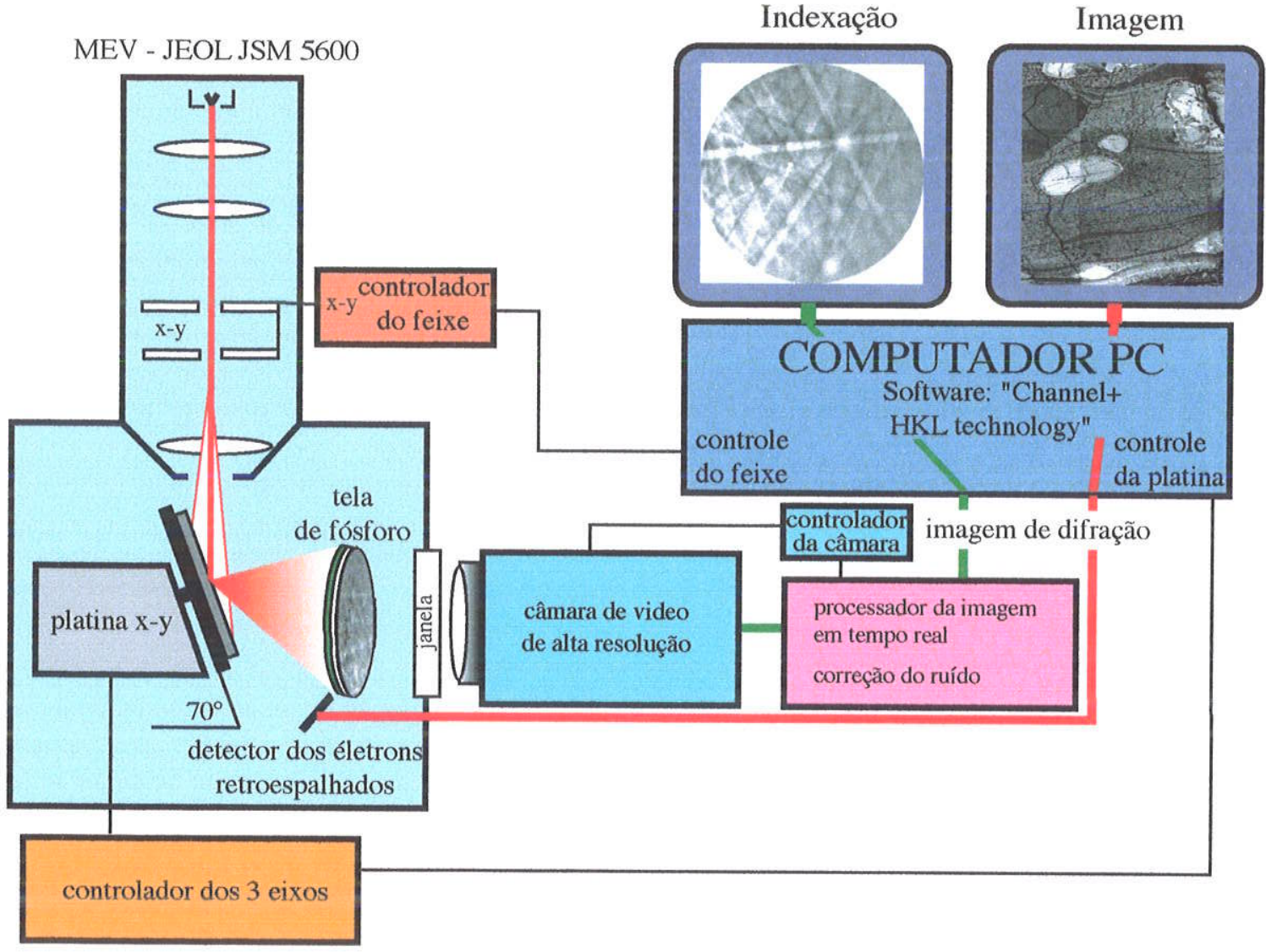

(b)

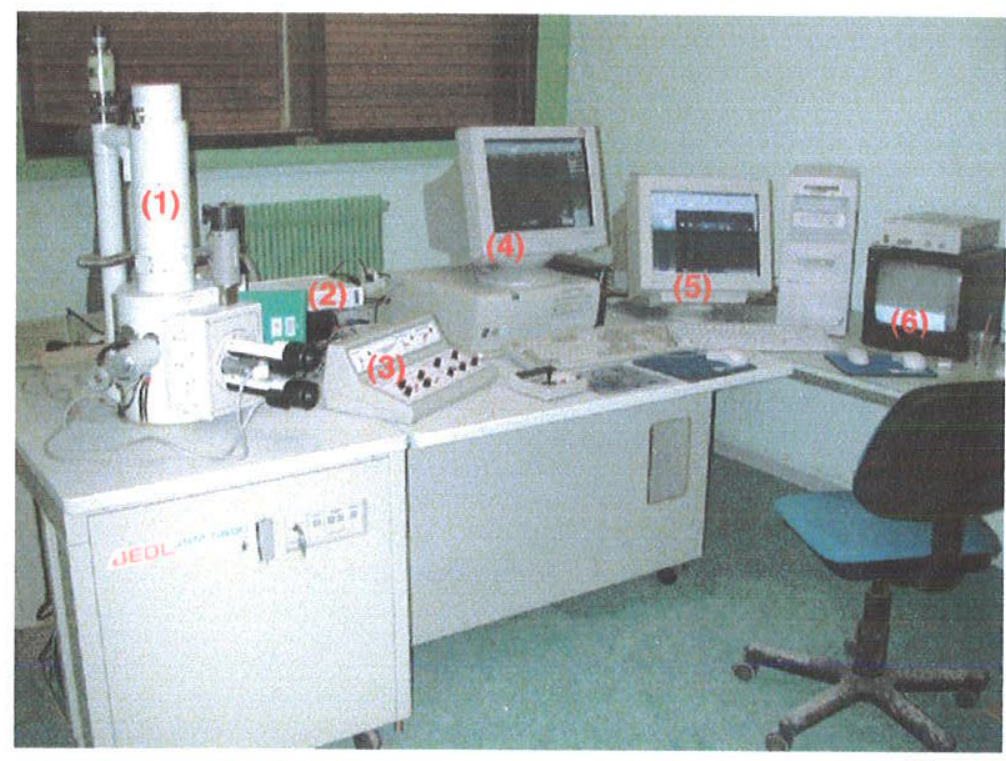

Fig. 1.8. Equipamento EBSD utilizado em Montpellier. (a) Esquema do equipamento. Site web: www.dstu.univ-montp2.fr/TECTONOPHY/EBSD/EBSD-measurements.html; (b) Foto do equipamento (julho 2002): (1) câmara eletrônica do MEV, (2) câmara de video, (3) sistema de regulagem das imagens cristalográficas, (4) monitor do PC controlador do MEV, (5) monitor do PC que permite acesso ao programa Channel+, (6) monitor que permite a visualização das figuras de difração que se formam sobre a tela de fósforo. 
Uma preparação extremamente cuidadosa das amostras é fundamental para a obtenção de boas figuras de difração. Irregularidades na superfície analisada provocarão um desvio do feixe eletrônico, podendo ocasionar uma superposição de várias imagens de difração que correspondem a diferentes pontos na amostra. Além disso, o feixe eletrônico incidente fará surgir uma corrente elétrica na superfície da amostra; a presença de relevos dificulta uma boa evacuação das cargas elétricas. $\mathrm{O}$ acúmulo das cargas gera uma mancha de grande intensidade instável na tela de fósforo, e perturba a seleção das bandas de Kikuchi. Um polimento mecânico permite alisar perfeitamente a superfície das amostras. Para a finalização, um polimento químico-mecânico (uma solução silicatada de SYTON, por exemplo, (Fynn e Powell, 1979)) é preferível a um polimento com uma pasta de diamantes, que pode gerar danos mecânicos. Ao final, uma metalização muito fina das amostras garante a eliminação das cargas; a maioria das amostras estudadas foram metalizadas com platina $(\sim 2.4 \AA$ de espessura). Todavia, a melhora na qualidade dos polimentos permite atualmente que se dispense a metalização.

\subsubsection{Indexação das figuras de difração}

A partir da imagem de difração digitalizada e tratada, o procedimento de indexação permite analisar a figura formada pelas bandas de Kikuchi e obter a totalidade de informações cristalográficas; ela consiste em detectar e identificar as bandas de difração. A detecção automática das bandas de Kikuchi na imagem de difração é baseada na transformada de Hough (1962). Uma linha pode ser parametrizada por sua distância $\rho$ na origem de um referencial de eixo $\mathrm{X}, \mathrm{Y}$ e pelo ângulo $\theta$ que é o ângulo entre a normal da linha e o eixo $\mathrm{X}$ no intervalo $[0 ; \pi]$ (Fig.1.9). A relação : $\rho_{i}=X_{k} \cos \theta_{i}+Y_{k} \sin \theta_{i}$, transforma todos os pontos $\left(X_{k}, Y_{k}\right)$ da linha em um simples ponto $\left(\rho_{i}, \theta_{i}\right)$ no espaço cartesiano $(\rho, \theta)$ de Hough.

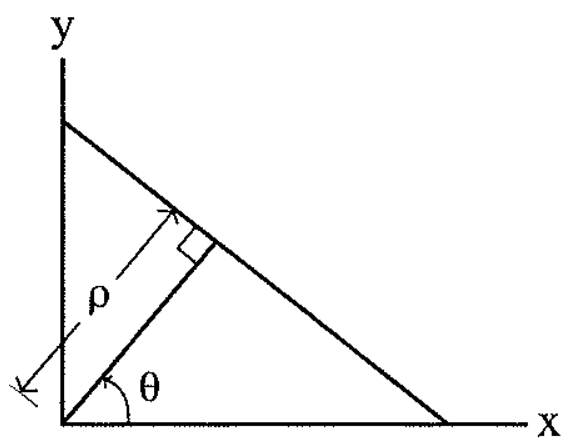

Fig. 1.9 Definição dos parâmetros $\rho$ e $\theta$ que caracterizam a localização de uma banda de Kikuchi em uma figura de difração. 
Uma linha brilhante formada por "pixels" de intensidade I e de coordenadas (X, Y) pode ser representada como um ponto brilhante pela transformada de Hough. Uma banda de Kikuchi composta por um número finito de linhas brilhantes de intensidades diferentes, será representada por uma soma de picos facilmente detectáveis (Fig. 1.10).

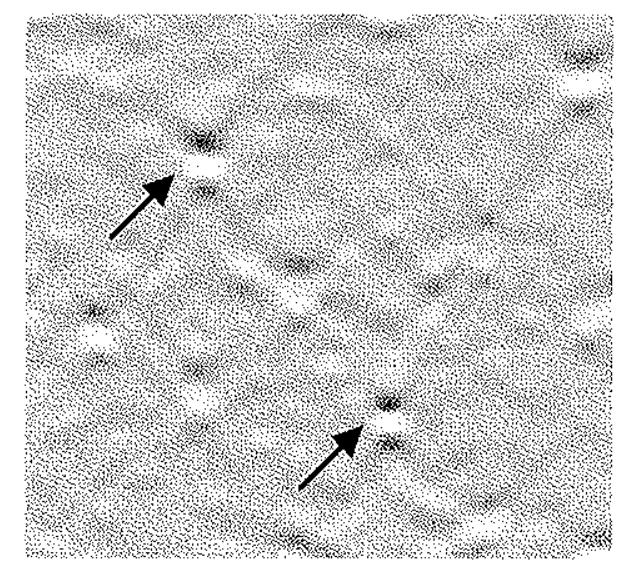

Fig. 1.10. Transformada de Hough de uma imagem EBSD. Cada grupo de pontos brilhantes define uma banda de Kikuchi (segundo o manual channel 4.2, HKL technology).

As orientações cristalográficas são determinadas por comparação entre a imagem de difração produzida no MEV e a esfera de difração modelizada (Fig. 1.11). Esta esfera que cobre todas as orientações possíveis de um cristal, é determinada a partir dos parâmetros reticulares e das posições equivalentes dos diferentes átomos na malha elementar (Schmidt e Olesen, 1989).

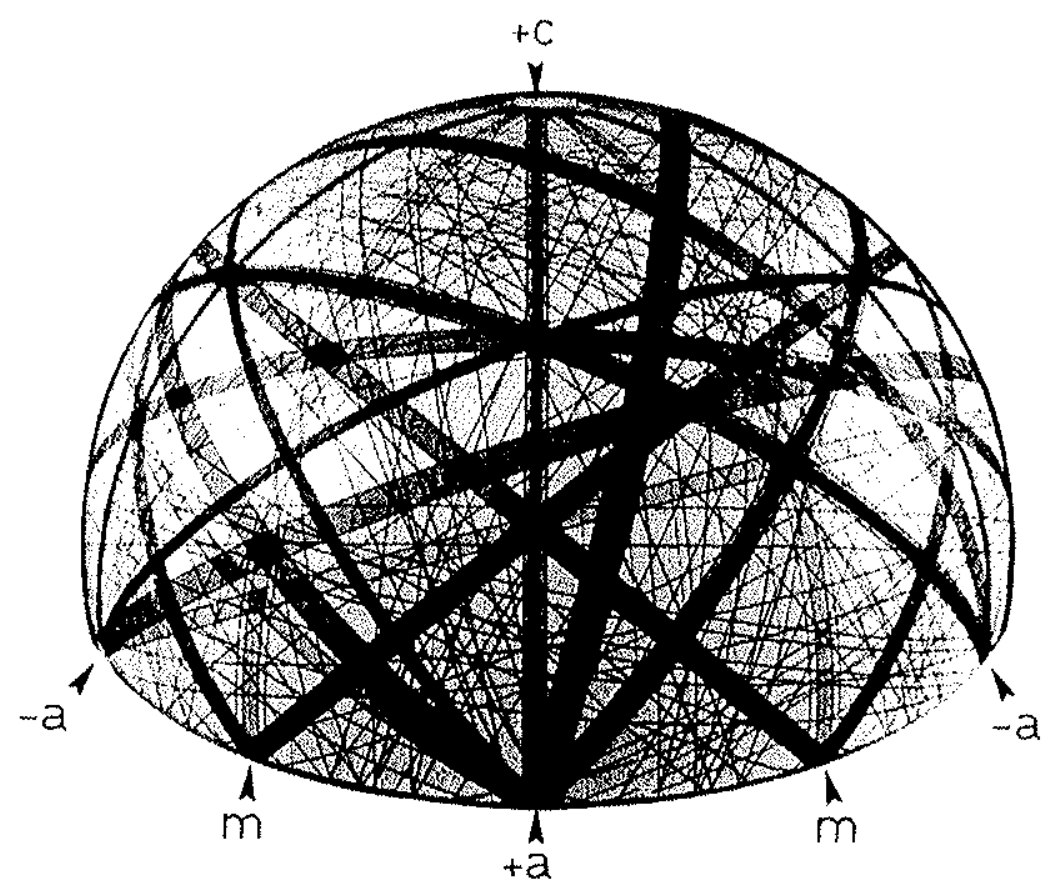

Fig. 1.11. Esfera de difração do quartzo obtida por simulação numérica (segundo Schmidt e Olesen, 1989). 
Por simetria, pode-se reduzir a esfera em uma parte elementar (Elementary Pattern of the Sphere, ou EPS) necessária para cobrir todas as imagens de difração possíveis. A esfera de difração de qualquer cristal apresenta um centro de simetria (Schmidt e Olesen, 1989). Este centro de simetria intrínseco da esfera de difração e as simetrias cristalinas têm como efeito a redução dos 32 grupos de simetria a 11 grupos (os grupos de Laue; tabela 1.1). Nas 10 simetrias indicadas por um asterisco na tabela 1.1, a parte elementar da esfera pode ser dividida em duas; isto significa que para cada uma dessas simetrias há duas soluções e a imagem de difração poderia então ser atribuída a duas orientações diferentes (Schmidt e Olesen, 1989). Neste caso, emprega-se o termo de pseudo-simetria. Um exemplo de pseudosimetria é a estrutura pseudo-hexagonal do quartzo romboédrico (grupo de Laue $-3 \mathrm{~m}$ ).

\begin{tabular}{|c|c|c|c|c|c|c|c|c|c|c|c|}
\hline $\begin{array}{c}\text { Grupos de } \\
\text { Laue }\end{array}$ & -1 & $2 / \mathrm{m}$ & $\mathrm{mmm}$ & $4 / \mathrm{m}$ & $4 / \mathrm{mmm}$ & -3 & $-3 \mathrm{~m}$ & $6 / \mathrm{m}$ & $6 / \mathrm{mmm}$ & $\mathrm{m} 3$ & $\mathrm{~m} 3 \mathrm{~m}$ \\
\hline & & $2 / \mathrm{m}$ & $\mathrm{mmm}$ & $4 / \mathrm{m}$ & $4 / \mathrm{mmm}$ & & $-4 \mathrm{~m}$ & $6 / \mathrm{m}$ & $6 / \mathrm{mmm}$ & & $\mathrm{m} 3 \mathrm{~m}$ \\
Grupos de & -1 & $\mathrm{~m}^{*}$ & $\mathrm{~mm} 2^{*}$ & $-4 *$ & $-42 \mathrm{~m}^{*}$ & -3 & $3 \mathrm{~m}^{*}$ & $-6 *$ & $-6 \mathrm{~m} 2 *$ & $\mathrm{~m} 3$ & 6 \\
simetria & 1 & 2 & 222 & 4 & $4 \mathrm{~mm}^{*}$ & 3 & 32 & 6 & $6 \mathrm{~mm}^{*}$ & 23 & $-43 \mathrm{~m}^{*}$ \\
& & 2 & & & 422 & & & & \\
\hline
\end{tabular}

Tabela 1.1. Correspondência entre os 11 grupos de Laue es 32 grupos de simetria. Os grupos para os quais o fenômeno de pseudo-simetria se produz são assinalados com * (segundo Schmidt e Olesen, 1989, modificado).

\section{Considerações experimentais}

A comparação entre os refletores detectados e modelizados necessita da conversão das bandas de Kikuchi detectadas na imagem de difração (2D) em vetores cristalográficos (3D). Esta conversão exige a determinação dos parâmetros de projeção tais como: o centro de projeção da imagem de difração ("pattern center"), a distância tela-amostra, a distorção da imagem de difração devida à projeção de uma esfera em um plano, e as relações entre as direções de referência no microscópio $\left(X_{m} Y_{m} Z_{m}\right)$, a amostra $\left(X_{s} Y_{s} Z_{s}\right)$ e a imagem na tela $(x y z)$.

A indexação baseia-se nos seguintes parâmetros cristalográficos:

- os ângulo entre os planos reticulares (os primeiros parâmetros para a indexação),

- a distância inter-reticular $\left(\mathrm{d}_{\mathrm{hkl}}\right)$

- a intensidade dos refletores $\left(\mathrm{I}_{\mathrm{hk}}\right)$. 
Para cada nova amostra, o operador procede a uma calibragem para determinar o centro de projeção da imagem de difração na tela de fósforo. Devido a centricidade própria do sistema EBSD, a posição do centro de projeção não varia de um ponto de medida ao outro. A seguir, um monocristal de silício colocado no porta-amostra, cuja orientação e as relações angulares interaxiais são conhecidas, é indexado a fim de fixar com precisão todos os parâmetros de projeção.

De 3 a 6 bandas de Kikuchi devem ser localizadas para efetuar uma boa indexação. Quando a detecção das bandas é feita de modo automático, fatores de qualidade de seleção das bandas são estabelecidos pelo programa channel+ como se segue:

- o contraste entre as bandas de Kikuchi e o fundo da imagem (Band constrast)

- o gradiente de intensidade na borda das bandas (Band slope)

- o número de comparações entre a figura de difração detectada e figuras de difração modelizadas para diferentes cristais escolhidos pelo operador (Search rounds)

- o desvio angular entre as bandas detectadas e simuladas (MAD).

\subsubsection{Precisão das orientações}

A precisão e a resolução espacial do EBSD são influenciadas por vários fatores, tais como: a natureza da amostra, a tensão de aceleração e a qualidade da imagem de difração. No entanto, uma resolução espacial de aproximadamente $200-500 \mathrm{~nm}$ e uma precisão absoluta de aproximadamente $1^{\circ}$ foram propostas como sendo valores razoáveis (Schmidt e Olesen, 1989; Randle et Engle, 2000). Diferentes estudos quantificaram a precisão das orientações medidas através do EBSD entre cristais da mesma amostra (Schmidt e Olesen, 1989; Krieger Lassen, 1996; Mainprice et al., 1993). Para esta precisão relativa do EBSD, Krieger Lassen (1996) estabelece um valor de $\sim 0.5^{\circ}$ quando as bandas são localizadas manualmente e $\sim 0.7^{\circ}$ quando as bandas são detectadas automaticamente, com 10 bandas utilizadas para a medida. Na situação mais realista, em que somente 4 ou 5 bandas são utilizadas para a indexação, a precisão no modo manual seria equivalente à do modo automático, com 10 bandas para a medida, ou seja, $\sim 0.7^{\circ}$.

Um dos principais limites das medidas no modo automático está ligado ao fenômeno de pseudo-simetria. Por exemplo, para o quartzo (mineral com uma estrutura pseudohexagonal), em modo automático, somente o eixo-c (eixo de rotação) pode ser determinado com precisão. No modo manual, uma opção do programa Channel+ permite visualizar as 
duas simulações pseudo-simétricas associadas à imagem detectada. O operador escolhe então a simulação que corresponde melhor à imagem detectada.

Mesmo no modo manual, as orientações cristalográficas são medidas muito rapidamente (alguns segundos por medida). Esta técnica impõe-se para a medida das rochas polifásicas como os eclogitos e os granulitos. Na verdade, esta técnica não é limitada pelas propriedades ópticas dos minerais e a orientação cristalográfica das fases de simetria cúbica, como a granada ou a magnetita, pode ser medida com uma precisão muito grande.

\subsubsection{Representação das OPR}

\subsubsection{1 - Os ângulos de Euler, a função de distribuição da orientação (ODF)}

Os ângulos de Euler são comumente utilizados para descrever a orientação de um cristal em uma amostra. Estes ângulos descrevem a orientação final do cristal no sistema de coordenadas $\mathrm{Kc}$, em relação ao sistema de coordenadas da amostra (Ke). Para a escolha dos eixos e dos ângulos, a convenção de Bunge (1982; 1985) é aplicada. Seja Kc (Xc, Yc, Zc) o sistema de coordenadas do cristal e Ke (Xe, Ye, Ze) o sistema de coordenadas da amostra. Nas rochas, o plano de foliação e a lineação tectônicas são geralmente utilizados para definir os eixos do referencial. O sistema de coordenadas do cristal pode ser fixado pela rede cristalográfica com os eixos do referencial paralelo às direções cristalográficas, por exemplo no caso de uma rede cúbica, os eixos podem ser paralelos às direções [100], [010], [001].

A orientação de um cristal na amostra é, portanto, definida pela orientação do sistema de coordenadas do cristal (Kc) em relação ao sistema de coordenadas da amostra (Ke), ou seja:

$$
\mathrm{Kc}=\mathrm{g} \cdot \mathrm{Ke}
$$

onde $\mathrm{g}=\left\{\varphi_{1}, \Phi, \varphi_{2}\right\}$, e $\varphi_{1}, \Phi$ e $\varphi_{2}$ são os três ângulos de Euler que descrevem a rotação final de Kc em relação a Ke. A descrição da rotação é ilustrada pela Fig. 1.12.

Os valores dos ângulos $\varphi_{1}, \Phi, \varphi_{2}$, que definem a orientação g, podem ser representados em um espaço cartesiano tridimensional chamado espaço de Euler, definido pelos eixos $\varphi_{1}, \Phi, \varphi_{2}$ e no qual um ponto representa a orientação de um cristal (Fig. 1.13). No espaço de 
Euler, a distribuição das orientações do cristal pode ser descrita por sua "ODF" (Orientation Distribution Function). Esta função $\mathrm{f}(\mathrm{g})$ descreve quantitativamente a fração volumétrica (dV) da amostra que tem uma orientação tal que:

$$
\mathrm{f}(\mathrm{g}) \mathrm{dg}=\mathrm{dV} / \mathrm{V}
$$

onde V é o volume total da amostra. Para uma distribuição uniforme dos cristais (sem orientação preferencial $), f(g)=1$.

A força da fábrica definida a partir da medida das orientações cristalográficas pode exprimir-se pelo número sem dimensão J ("fabric strength J-index", Bunge, 1982),

$$
J=\int f(g)^{2} d g
$$

para uma fábrica sem orientação preferencial, $\mathrm{J}=1$ e para um monocristal, $\mathrm{J}=\infty$. 


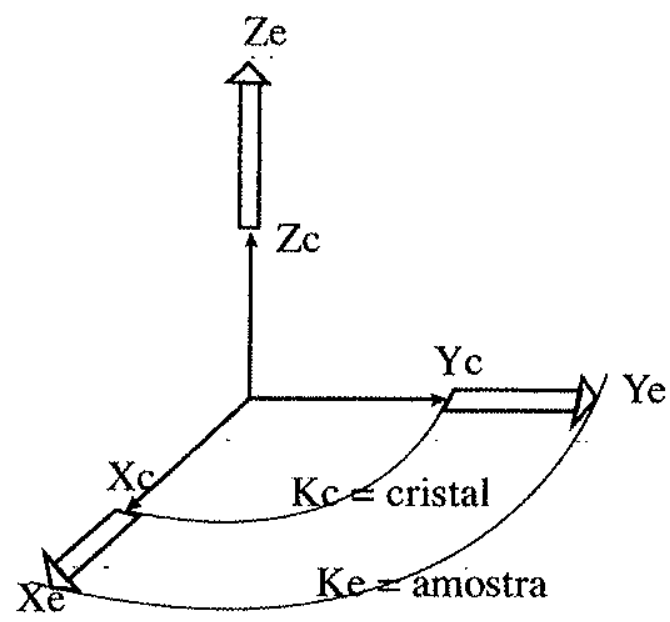

(a)

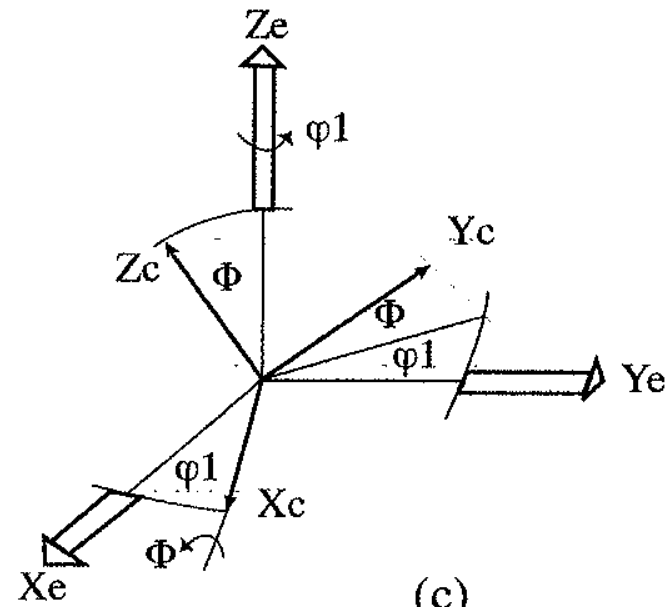

(c)
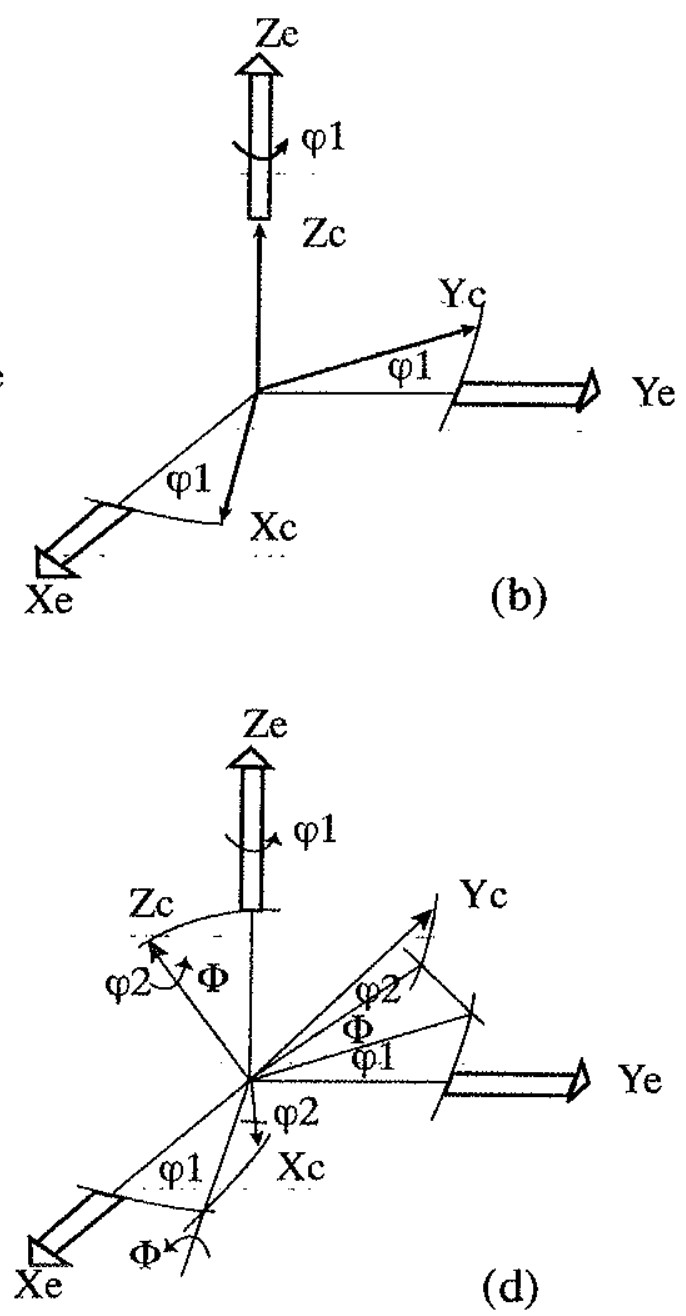

Fig. 1.12. Definição dos ângulos de Euler (segundo Bunge, 1985). Na figura 1.12 (a), o sistema de coordenadas do cristal $(\mathrm{Kc})$ está paralelo o sistema de coordenadas da amostra (Ke). Ke está sucessivamente rotacionado:

1. de um ângulo $\varphi 1$ em volta do eixo $\mathrm{Ze}(\mathrm{b})$

2. de um ângulo $\Phi$ em volta do eixo $\mathrm{Xe}(\mathrm{c})$

3. de um ângulo $\varphi 2$ em volta do eixo Ze (d)

Todas as orientações posem ser obtenidas por $0 \leq \varphi 1 \leq 2 \pi, 0 \leq \Phi \leq \pi, 0 \leq \varphi 2 \leq 2 \pi$

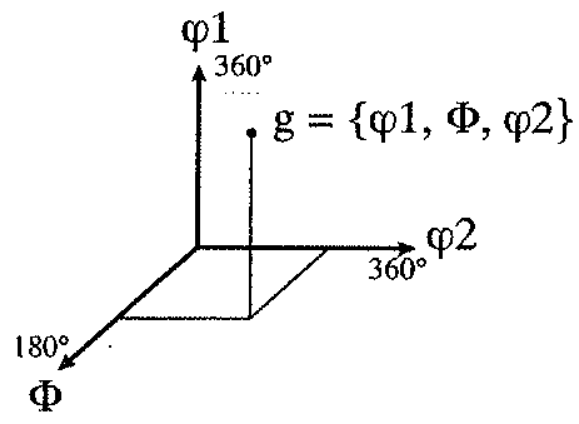

Fig. 1.13. O espaço de Euler 


\subsubsection{As figuras de pólo e os mapas de orientação}

Nas Geociências, a representação mais difundida das orientações dos eixos ou dos planos cristalográficos dá-se em forma de figuras de pólos no referecial estrutural (foliação, lineação). A projeção é de igual área no hemisfério inferior e a densidade de orientação em \% para $1 \%$ da área do diagrama de Schmidt (Fig. 1.14a).

As figuras de pólos inversas (Fig. 1.14b) são igualmente utilizadas para representar as medidas de orientação. Nas figuras de pólos inversas, as orientações de uma direção estrutural (a lineação, por exemplo) são representadas no referencial cristalográfico. Esta representação é vantajosa para determinar as orientações cristalográficas suscetíveis de serem correlatas às direções principais da deformação finita. Este tipo de representação é utilizada nos Capítulos 4 e 5 para evidenciar os sistemas de deslizamento.
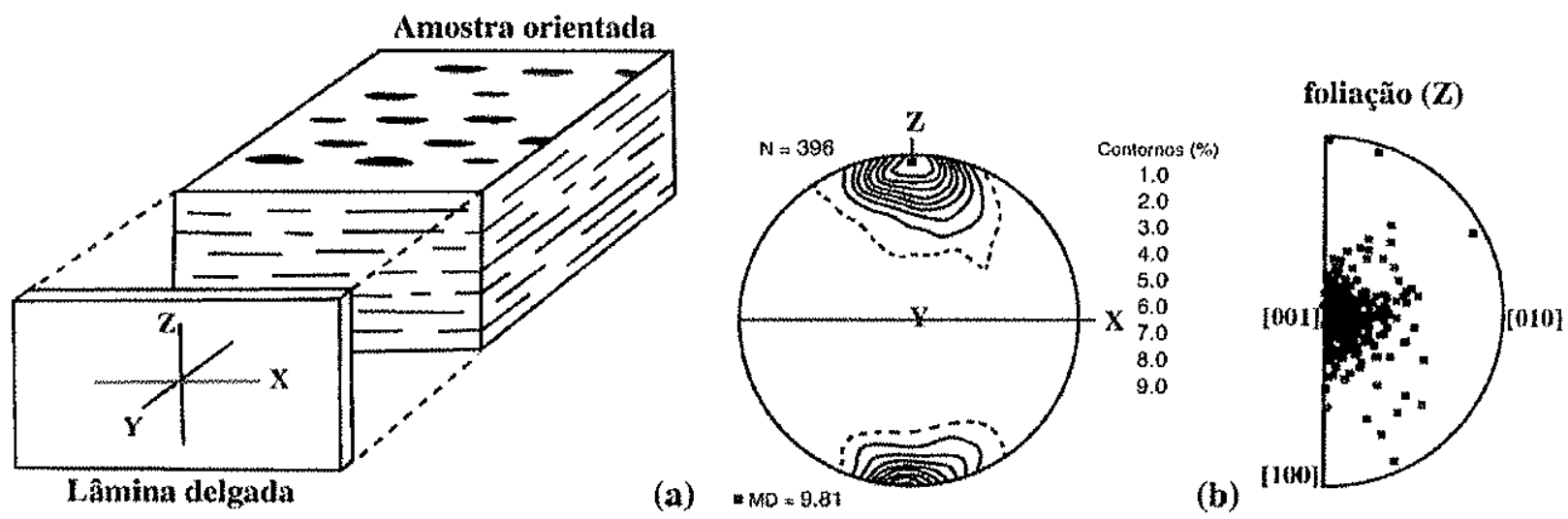

Fig. 1.14. Orientação preferencial da rede da biotita medida numa lâmina delgada orientada. (a) Figura de pólo do eixo-c da biotita. Ele está muito concentrado em torno de $Z$, o pólo de foliação. Projeção de igual área, hemisfério inferior. Contornos: $1,2,3 \%$ para $1 \%$ de área. $\mathrm{N}$ é o número de medida $\mathrm{e}$ MD é a densidade máxima; (b) Figura de pólo inversas da biotita. $O$ pólo da foliação concentra-se em torno do eixo-c (eixo [001]).

Com um MEV equipado com uma platina automática, é possível medir as orientações cristalográficas passo a passo. Esta técnica permite o estabelecimento de mapas de orientação (Fig. 1.15). Para estes mapas, a cada orientação $\left(\varphi_{1}, \Phi, \varphi_{2}\right)$ é associada uma cor que deriva da combinação das três cores primárias (vermelho, verde, azul). A possibilidade de uma cartografia cristalográfica torna possível estudos muito precisos das microestruturas, tais como, os grãos de tamanhos pequenos, as variações de orientações em um mesmo grão, ou ainda o estudo das relações entre os grãos recristalizados e os porfiroclastos. 
(a)

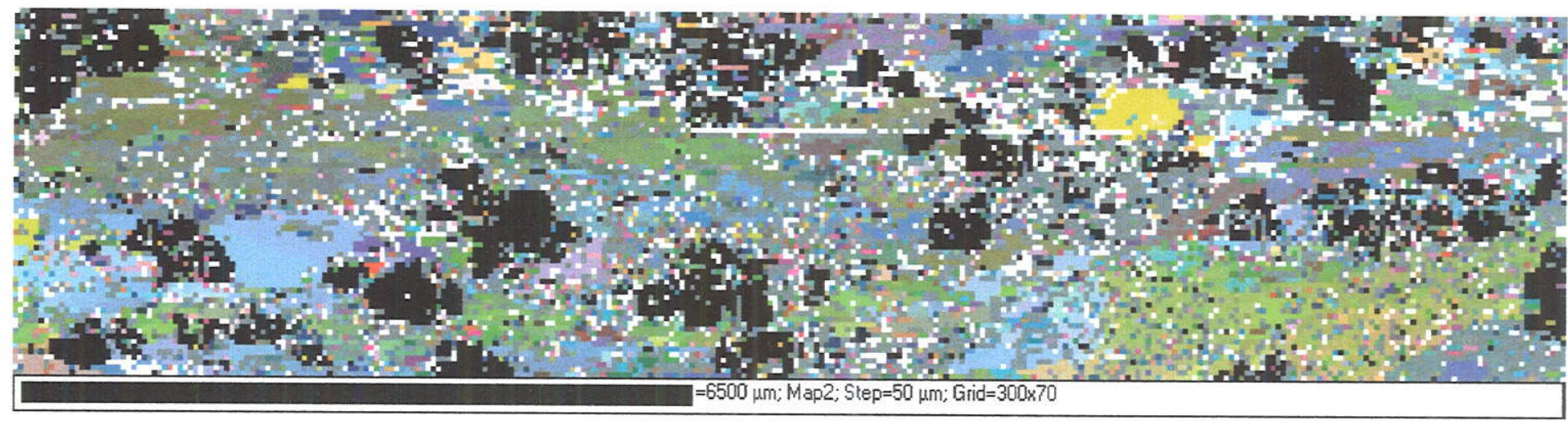

(b)

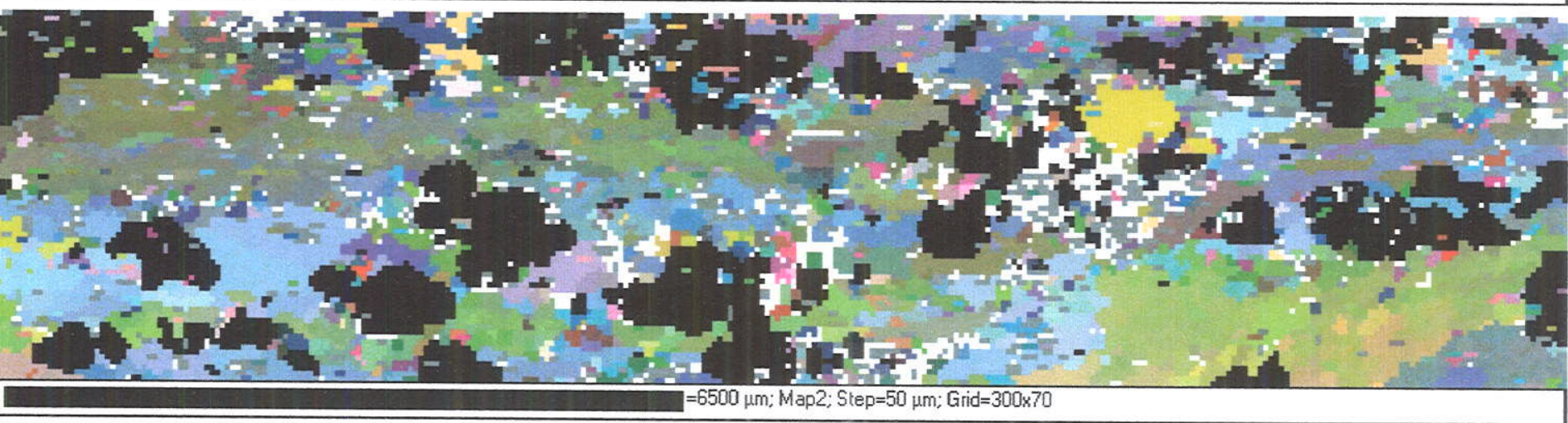

(c)
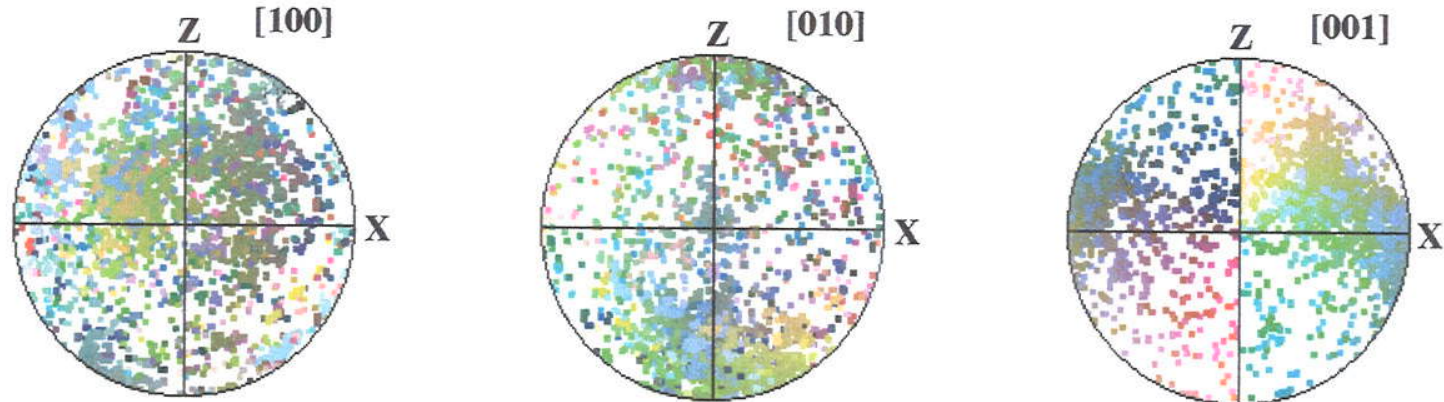

Fig. 1.15. OPR da onfacita de um eclogito muito deformado dos Alpes (eclo 01, Monte Mucrone). (a) Mapa de orientação bruta; (b) Mapa de orientação refinada. Em branco os pontos não-indexados, em preto a granada e com cores as orientações cristalográficas da onfacita. Para cada orientação ( $\varphi 1, \Phi, \varphi 2)$ tem uma cor. As variações de tonalidade de uma mesma cor descrevem pequenas variações de orientação no interior de um mesmo grão (sub-grão). Área (a) : $(15000 \times 3500 \mu \mathrm{m})$; uma medida a cada $50 \mu \mathrm{m}$; (c) Figuras de pólos dos eixos cristalográficos [100], [010] e [001] da onfacita. Mesmo código que 


\subsection{As propriedades físicas anisotrópicas das rochas}

\subsection{1- Abordagem}

A maioria das rochas apresenta uma variação de suas propriedades físicas (sísmica, magnética, térmica,...) de acordo com a direção de medida. Esta anisotropia pode ter diversas origens, por exemplo, uma microfraturação, uma orientação preferencial dos constituintes da rocha, um bandamento composicional, etc... Com o aumento da pressão de confinamento, as microfraturas fecham-se e a anisotropia devida à orientação preferencial dos cristais (anisotropia intrínseca) predominará (por exemplo, Kern, 1990). Em condições de pressão temperatura de crosta profunda, o desenvolvimento de orientações preferenciais dos minerais por fluxo das rochas, vai portanto, ser determinante para as propriedades físicas anisotrópicas de tais rochas. Devido às relações entre deformação - orientação preferencial dos minerais anisotropia das propriedades físicas, esta anisotropia é uma fonte potencial para informar sobre os processos geodinâmicos na origem da deformação das rochas.

Há duas maneiras de determinar as propriedades físicas das rochas. A primeira consiste em medi-las em laboratório em condições de pressão e de temperatura variadas (por exemplo, Christensen e Mooney, (1995) para as propriedades sísmicas). A segunda consiste em calcular as propriedades físicas do agregado. Quando o agregado é composto por várias fases diferentes, a contribuição de cada fase à anisotropia global é calculada levando-se em conta as propriedades intrínsecas do monocristal da fase, e/ou a forma dos grãos, e a distribuição de orientação específica (a ODF, por exemplo) dos grãos da fase em questão (Grolier et al., 1991). A determinação das proporções volumétricas de cada fase mineral permite o cálculo das propriedades físicas do agregado. Os métodos de cálculo das propriedades petrofísicas a partir das OPR são descritos por Mainprice e Humbert (1994).

Nos dois parágrafos que se seguem, as propriedades sísmicas e magnéticas das rochas são apresentadas sucintamente. A ênfase é dada ao cálculo da anisotropia sísmica através das OPR. O procedimento de medida da anisotropia de susceptibilidade magnética (ASM) é detalhado em vários trabalhos de síntese (p. ex., Archanjo, 1993; Tarling e Hrouda, 1993; Borradaile e Henry, 1997; Bouchez, 1997). Em relação às rochas metamórficas, Raposo e Egydio-Silva (2002) publicaram um trabalho sintético sobre a medida das fábricas magnéticas (ASM e ARM - anisotropia de remanência magnética) das rochas de alto grau da faixa Ribeira, e um estudo das relações entre as tramas cristalográficas e as tramas magnéticas para 
cinco milonitos granulíticos da Faixa Ribeira é o objeto do Capítulo 5 - anexo III. No parágrafo consagrado à medida da ASM serão citados, brevemente, alguns pontos fundamentais ou complementares dos dois trabalhos citados acima.

\subsubsection{As propriedades sísmicas}

\subsubsection{Propriedades elásticas dos cristais}

Devido à organização dos átomos, os cristais têm propriedades elásticas anisotrópicas. A passagem de uma onda sísmica no cristal induz um esforço e uma deformação reversível ligadas, segundo a lei de Hooke, por:

$$
\sigma_{\mathrm{ij}}=\mathrm{C}_{\mathrm{ijkl}} \cdot \varepsilon_{\mathrm{kl}}
$$

onde $\sigma_{\mathrm{ij}}$ é o esforço aplicado, $\varepsilon_{\mathrm{kl}}$ a deformação, $\mathrm{C}_{\mathrm{ijkl}}$ o tensor das constantes de rigidez elástica.

As constantes de elasticidade são teoricamente $81\left(3^{4} ; \mathrm{i}, \mathrm{j}, \mathrm{k}, \mathrm{l}\right.$ variando de 1 a 3$)$. Mas, devido às propriedades de simetria dos tensores da deformação e do esforço, $C_{i j k l}=C_{j i k l}=$ $\mathrm{C}_{\mathrm{ijkl}}=\mathrm{C}_{\mathrm{jilk}}$, os 81 coeficientes de rigidez elástica reduzem-se a 36 coeficientes independentes. Além disso, a propriedade de centrossimétria da elasticidade (mesma propriedade para duas direções simétricas em relação ao centro simétrico do cristal) vai reduzir o número de coeficientes independentes a 21 , que podem ser representados sob a forma de uma matriz ( $6 \mathrm{X}$ 6) simétrica:

$$
\begin{array}{llllll}
\mathrm{C}_{11} & \mathrm{C}_{12} & \mathrm{C}_{13} & \mathrm{C}_{14} & \mathrm{C}_{15} & \mathrm{C}_{16} \\
\mathrm{C}_{21} & \mathrm{C}_{22} & \mathrm{C}_{23} & \mathrm{C}_{24} & \mathrm{C}_{25} & \mathrm{C}_{26} \\
\mathrm{C}_{31} & \mathrm{C}_{32} & \mathrm{C}_{33} & \mathrm{C}_{34} & \mathrm{C}_{35} & \mathrm{C}_{36} \\
\mathrm{C}_{41} & \mathrm{C}_{42} & \mathrm{C}_{43} & \mathrm{C}_{44} & \mathrm{C}_{45} & \mathrm{C}_{46} \\
\mathrm{C}_{51} & \mathrm{C}_{52} & \mathrm{C}_{53} & \mathrm{C}_{54} & \mathrm{C}_{55} & \mathrm{C}_{56} \\
\mathrm{C}_{61} & C_{62} & C_{63} & C_{64} & \mathrm{C}_{65} & C_{66}
\end{array}
$$


O número de coeficientes independentes decresce até 3 quando a simetria do cristal aumenta (simetria cúbica). As propriedades elásticas dos minerais e das rochas são abordadas de modo detalhado em numerosas obras (p. ex., Nye, 1972; Grolier et al., 1991).

As constantes de rigidez elástica podem ser calculadas levando-se em conta a pressão (P) e a temperatura (T). Os cálculos são baseados na seguinte equação:

$$
\mathrm{C}_{\mathrm{ij}}(\mathrm{P}, \mathrm{T})=\mathrm{C}_{\mathrm{ij} 0}+\left(\mathrm{dC}_{\mathrm{ij}} / \mathrm{dP}\right) \cdot \Delta \mathrm{P}+\left(\mathrm{dC}_{\mathrm{ij}} / \mathrm{dT}\right) \cdot \Delta \mathrm{T}+1 / 2\left(\mathrm{~d}^{2} \mathrm{C}_{\mathrm{ij}} / \mathrm{dP}^{2}\right) \cdot(\Delta \mathrm{P})^{2}
$$

onde $\mathrm{C}_{\mathrm{ij} 0}$ é a constante de rigidez elástica a pressão e a temperatura ambientes; $\left(\mathrm{dC}_{\mathrm{ij}} / \mathrm{dP}\right)$ et $\left(\mathrm{dC}_{\mathrm{ij}} / \mathrm{dT}\right)$ as derivadas primeiras das constantes elásticas em função da pressão e da temperatura, e $\left(\mathrm{d}^{2} \mathrm{C}_{\mathrm{ij}} / \mathrm{dP}^{2}\right)$ a derivada segunda das constantes elásticas em função da pressão; $\Delta \mathrm{P}$ e $\Delta \mathrm{T}$ a diferença entre a pressão e a temperatura in situ e as condições ambientes.

\subsubsection{Cálculo das velocidades sísmicas}

As velocidades de propagação Vp, Vs1, Vs2 em todas as direções do espaço são calculadas a partir dos coeficientes de elasticidade, onde:

- Vp é a velocidade de uma onda de compressão (movimento das partículas paralelo à direção de propagação da onda),

- Vs1 e Vs2 são as velocidades de propagação das ondas de cisalhamento $S_{1}$ e $S_{2}$ (movimento das partículas perpendicular à direção de propagação da onda).

Para cada direção, Vp, Vsı e Vs2 são soluções da equação de Christoffel :

$$
\operatorname{Det}\left|C_{i j k l} X_{i} X_{j}-\delta_{i k} \rho V^{2}\right|=0
$$

onde: $\mathrm{C}_{\mathrm{ijkl}}$ é a matriz dos coeficientes de rigidez elástica,

$\mathrm{X}_{\mathrm{i}} \mathrm{X}_{\mathrm{j}}$ os cossenos diretores da direção de propagação da onda,

$\delta_{\mathrm{ik}}$ o delta de Kronecker,

$\rho$ a densidade do meio,

$\mathrm{V}$ a velocidade das ondas em uma determinada direção.

As velocidades de propagação das ondas elásticas em um agregado polifásico são calculadas introduzindo-se na equação de Christoffel a matriz média dos coeficientes de rigidez elástica da rocha (Peselnick et al., 1974) calculada a partir da equação: 


$$
\overline{C_{i j}}=\sum_{l}^{s} f s \sum_{1}^{N s} C_{i j^{\prime}} / N s
$$

onde $S$ é o número de fases minerais presentes na rocha, Ns o número de cristais da fase mineral $S$, fs a fração volumétrica da fase $S$ e $C_{i j}$ a matriz dos coeficientes de rigidez elástica do $\mathrm{N}^{\text {ssimo }}$ grão da família $\mathrm{S}$, em função do referencial estrutural.

Para o cálculo das velocidades sísmicas, a matriz dos coeficientes elásticos pode ser calculada utilizando-se a hipótese de Voigt, que leva em consideração a deformação uniforme (Voigt, 1928), de Reuss, a qual leva em consideração o esforço uniforme (Reuss, 1929), ou a hipótese de Hill (Hill, 1965), que é a média aritmética dos coeficientes de Voigt e de Reuss.

\subsubsection{Os efeitos da anisotropia sísmica}

Quando as ondas de cisalhamento (ondas S) atravessam um meio anisotrópico, elas dividem-se em duas ondas polarizadas em planos ortogonais, as quais se propagam com velocidades diferentes. Assim, a diferença das velocidades de propagação das duas ondas polarizadas reflete a anisotropia do meio atravessado (Fig. 1.16).

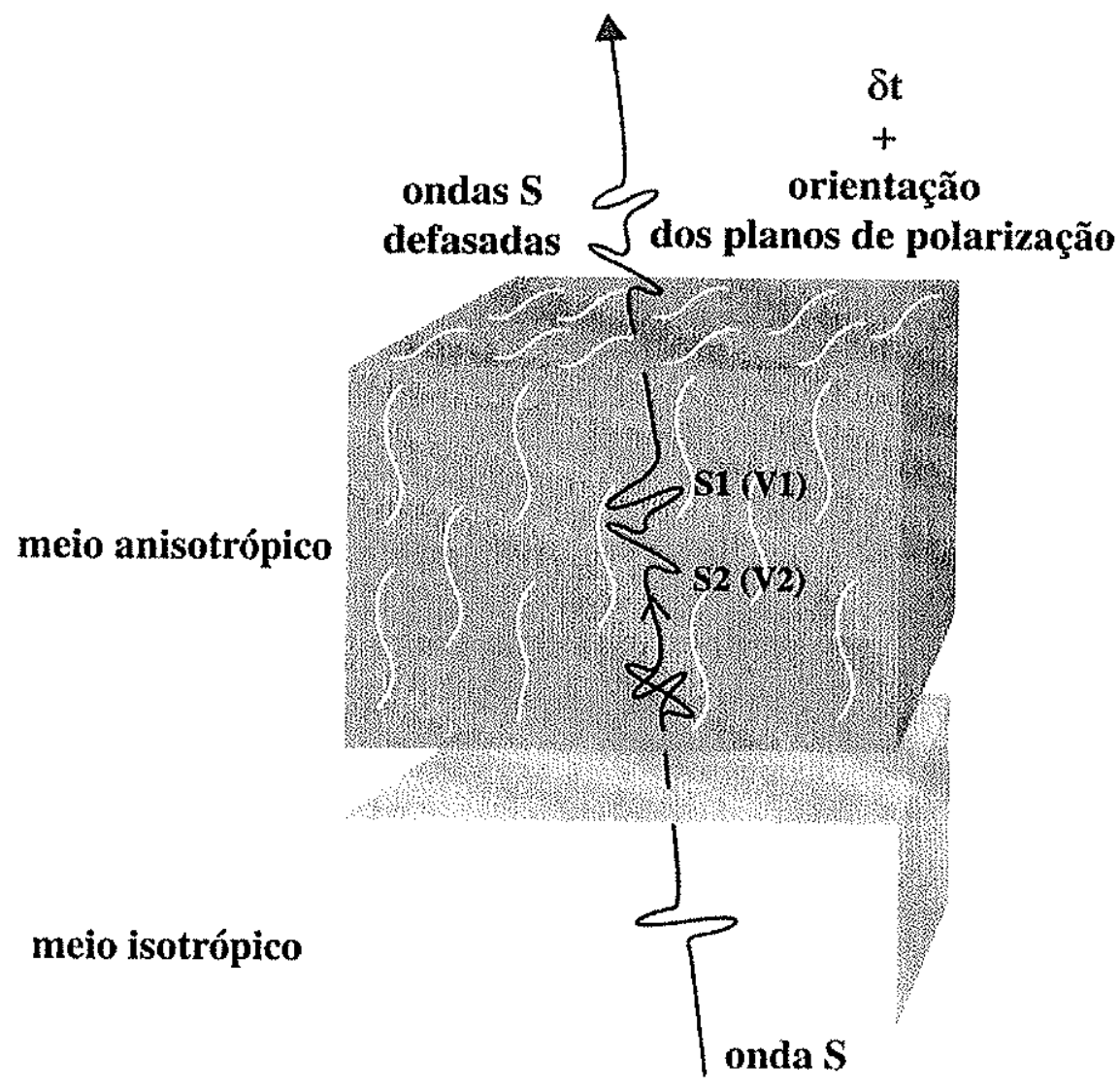

Fig. 1.16 Defasagem de uma onda $\mathrm{S}$ que atravessa um meio anisotrópico. 
Em um meio anisotrópico, as ondas de compressão (ondas P) não mostram anisotropia de polarização; no entanto, a velocidade de propagação de tais ondas varia de acordo com a direção de propagação. Esta diferença de velocidade pode, portanto, ser interpretada em termos de anisotropia azimutal do meio atravessado.

A anisotropia das ondas P (Avp) é definida por Birch (1961) como:

$$
A V p=\left(V p_{\text {max }}-V p_{\text {mata }}\right) /\left(\left(V p_{\text {média }}\right)=\left(V p_{\text {máx }}-V p_{\text {mfra }}\right) /\left(\left(V p_{\text {máx }}+V p_{\text {man }}\right) / 2\right)\right.
$$

onde $V p_{\text {máx }}$ e $V p_{\text {mín }}$ são a velocidade máxima e a velocidade mínima das ondas $P$.

A anisotropia de polarização das ondas $S$ para cada direção de propagação é definida como:

$$
\mathrm{AVs}=\left(\mathrm{Vs}_{1}-\mathrm{Vs}_{2}\right) /\left(\left(\mathrm{Vs}_{1}+\mathrm{Vs}_{2}\right) / 2\right)
$$

O atraso na defasagem das ondas $S$, $\delta$ t, é definido por Mainprice e Silver (1993) como:

$$
\delta \mathrm{t}=\mathrm{LAVs} / \mathrm{Vs}_{\text {média }}=\mathrm{L}\left(\mathrm{Vs}_{1}-\mathrm{Vs}_{2}\right) /\left(\left(\mathrm{Vs}_{1}+\mathrm{Vs}_{2}\right) / 2\right)^{2}
$$

onde L é o comprimento do trajeto da onda no meio anisotrópico.

\subsubsection{A anisotropia de susceptibilidade magnética (ASM)}

A susceptibilidade magnética (k) é uma propriedade física intrínseca dos minerais que constituem as rochas. Em um meio magnetizado isotrópico, $k$ é um escalar enquanto que em um meio imantado anisotrópico, $\mathrm{k}$ é um tensor simétrico de segunda ordem, que responde à equação:

$$
\mathrm{M}_{\mathrm{i}}=\mathrm{k}_{\mathrm{ij}} \mathrm{H}_{\mathrm{j}}
$$

onde $\mathrm{M}_{\mathrm{i}}$ é a magnetização induzida na direção i e $\mathrm{H}_{\mathrm{j}}$ é o campo magnético indutor na direção $j(i, j=1,2,3)$.

O tensor de susceptibilidade magnética $\left(\mathrm{k}_{\mathrm{ij}}\right)$ é representado por um elipsóide: o elipsóide de ASM (Fig. 1.17). Os três semi-eixos principais do elipsóide correspondem aos valores dos vetores próprios da matriz onde $\mathrm{K}_{\mathrm{max}} \geq \mathrm{K}_{\mathrm{int}} \geq \mathrm{K}_{\mathrm{mfn}}$ ou $\mathrm{K}_{11} \geq \mathrm{K}_{22} \geq \mathrm{K}_{33}$ ou ainda $\mathrm{K}_{1} \geq \mathrm{K}_{2} \geq \mathrm{K}_{3}$. 
A ASM de uma rocha é a resultante das contribuições do conjunto dos minerais que compõem a rocha. Tais minerais podem ter comportamentos magnéticos diferentes: diamagnético, paramagnético e ferromagnético (s.l.), ver por exemplo Dunlop e Ozdemir (1997) para uma descrição dos diversos comportamentos magnéticos dos minerais.

As duas principais causas da ASM são a anisotropia magnetocristalina e a anisotropia de forma dos grãos. No caso da anisotropia magnetocristalina, os eixos principais de anisotropia são paralelos a eixos cristalográficos privilegiados. Este tipo de anisotropia diz respeito aos minerais de baixa susceptibilidade, tais como os silicatos ferríferos como a biotita ou o anfibólio, e encontra-se igualmente nos minerais de alta susceptibilidade e relativa baixa simetria cristalina, como a hematita, a ilmenita ou a pirrotita (Borradaile e Henry, 1997; Hrouda, 1982; Rochette, 1992). A anisotropia magnética devida à forma do grão diz respeito aos minerais de alta susceptibilidade, dos quais a magnetita é o representante mais característico. Na magnetita polidomínio, a susceptibilidade máxima coincide com o eixo longo do grão, enquanto que na magnetita monodomínio a magnetização é inexistente ao longo do eixo longo do grão, e pode, portanto, gerar uma fábrica magnética inversa (Rochette, 1989).

Para as medidas da ASM, amostragens sistemáticas são realizadas no campo. Cilindros de rochas orientados em relação ao referencial geográfico são coletados com o auxílio de perfuratriz portátil equipada com uma broca amagnética diamantada. Tais amostras são a seguir cortadas perpendicularmente a seu eixo para formar cilindros de tamanho padronizado $(2.5 \mathrm{~cm}$ de diâmetro e $2.2 \mathrm{~cm}$ de comprimento), que são medidas individualmente.

Aparelhos clássicos para a medida da suscetibilidade são os suscetômetros do tipo kappabridge (para amostras da Faixa Ribeira: o KLY-3S, Agico, República Tcheca). Tais aparelhos de campo fraco alternativo (aproximadamente $0.1 \mathrm{mT}$ ) funcionam de acordo com o princípio da ponte autocompensada e medem, na verdade, a perturbação de indutividade gerada por uma amostra em uma bobina. O cálculo da suscetibilidade axial em quinze posições diferentes permite acessar aos termos diagonais e simétricos do tensor de ASM da amostra. O final do procedimento de cálculo consiste na diagonalização da matriz que permite obter os três vetores próprios que correspondem aos eixos principais (Kmáx, Kint e Kmín) do elipsóide de ASM. 
Vários parâmetros caracterizarão o elipsóide de ASM:

- a susceotibilidade média, $\mathrm{Km}=(\mathrm{Kmáx}+\mathrm{Kint}+\mathrm{Kmín}) / 3$;

- a anisotropia total, $\mathrm{P}=\mathrm{Kmáx} / \mathrm{K}$ mín;

- um parâmetro de forma ou parâmetro de Jelinek (1981) expresso por:

$$
\mathrm{T}=\frac{\ln \frac{\text { Kint }}{\text { Kmín }}-\ln \frac{\text { Kmáx }}{\text { Kint }}}{\ln \frac{\text { Kint }}{\text { Kmín }}+\ln \frac{\text { Kmáx }}{\text { Kint }}}
$$

onde $-1 \leq \mathrm{T} \leq 1$; para $0<\mathrm{T}<1$, o elipsóide é achatado, e para $-1<\mathrm{T}<0$ o elipsóide é alongado (em forma de charuto).

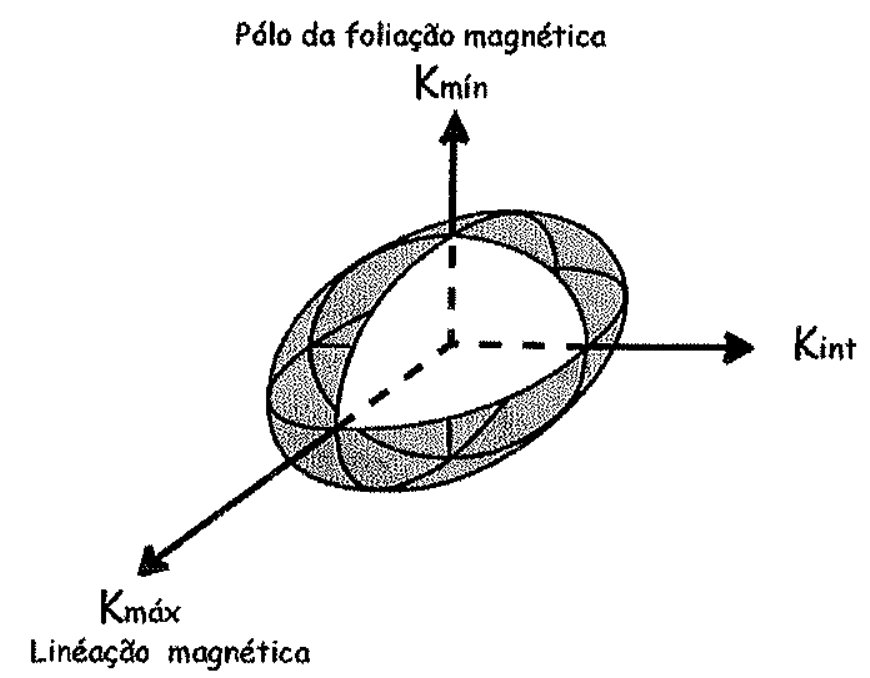

Fig. 1.17. O elipsóide de ASM e os eixos principais Kmáx, Kint e Kmín. 
$\overline{\text { SOLIDOTDA SO }}$ 


\section{Capítulo 2.}

\section{Orientações preferenciais da rede medidas através da técnica EBSD e propriedades sísmicas dos eclogitos}

\subsection{Resumo}

Neste trabalho, foram investigados os mecanismos de deformação e as propriedades sísmicas em dez amostras de eclogito através das análises de suas micro-estruturas e orientação preferencial da rede cristalina (OPR). Os eclogitos são oriundos de domínios orogênicos de idade e evolução geodinâmica diferentes: os Alpes, a faixa caledoniana na Noruega, o cinturão de idade panafricana no Mali e a faixa Sulu-Dabishan na China.

A OPR da onfacita e da granada foram determinadas através da técnica de difração de elétrons retro-espalhados (ESBD). A granada não apresenta uma orientação preferencial marcante (as OPR da granada são apresentadas no apêndice I). Ao contrário da granada, a onfacita mostra uma forte OPR caracterizada pelos eixos-[001] concentrados subparalelamente à lineação mineral, e os pólos-(010) concentrados sub-perpendicularmente à foliação.

Com o intuito de analisar os mecanismos de deformação responsáveis por tais OPR na onfacita, fez-se uma comparação destas com as OPR simuladas em modelos numéricos de deformação viscoplástica. As OPR medidas apresentam um bom ajuste com os modelos nos quais os sistemas de deslizamento dominantes são $1 / 2<110>\{1 \overline{1} 0\}$ [001] $\{110\}$ e [001] (100). A ativação destes sistemas de deslizamento dominantes estão de acordo com os estudos realizados através do microscópio eltrônico de transmissão (MET) em onfacitas deformadas naturalmente (Van Roermund e Boland, 1981; Buatier et al., 1991). Os modelos do desenvolvimento das OPR da onfacita através da deformação plástica são apresentados de maneira detalhada no Capítulo 3.

As propriedades sísmicas dos eclogitos são calculadas combinando-se as OPR medidas e as constantes elásticas dos monocristais de onfacita e granada. Embora as anisotropias sísmicas para eclogitos sejam muito baixas (menos de $3 \%$ para ondas $\mathrm{P}$ e $\mathrm{S}$ ), ondas $\mathrm{P}$ são caracterizados geralmente por uma velocidade máxima sub-paralela à lineação mineral e uma velocidade mínima aproximadamente normal à foliação. A velocidade média 
para ondas $\mathrm{P}$ e S é alta ( 8.6 e $4.9 \mathrm{~km} / \mathrm{s}$, respectivamente). O padrão de anisotropia para ondas $S$ mostra relações complexas com o arcabouço estrutural, mas o plano de polarização tende a ser, de uma maneira geral, paralelo à foliação.

Os coeficientes de reflexão calculados mostram que uma interface eclogito/crosta é boa refletora $(R c>0.1)$, enquanto que uma massa de eclogito envolta no manto superior seria dificilmente detectável através das técnicas de sísmica de reflexão.

Ver artigo "EBSD-measured lattice-preferred orientations and seismic properties of eclogites" no anexo $I$. 


\section{Capítulo 3.}

\section{Deformação plástica e desenvolvimento das orientações preferenciais da rede nos eclogitos}

\subsection{Resumo}

Utiliza-se um modelo auto-coerente viscoplástico (VPSC) para simular o desenvolvimento das orientações preferenciais da rede (OPR) em resposta a uma deformação plástica acomodada por um deslizamento intracristalino ("dislocation glide"). Estas simulações levam em conta os sistemas de deslizamento identificados na onfacita deformada naturalmente e no diopsído deformado experimentalmente.

As OPR simuladas reproduzem as características das OPR da onfacita nos eclogitos deformados naturalmente : uma forte concentração dos eixos [001] sub-paralelos à lineação e dos pólos dos planos (010) sub-perpendiculares à foliação. Estes modelos conciliam as interpretações das OPR da onfacita nos eclogitos e as observações ao MET, pois mostram que as OPR da onfacita nos eclogitos naturalmente deformados poderiam desenvolver-se através da ativação dos sistemas de deslizamento : 1/2<110>\{110\}[001] $\{110\}$ e $[001](100)$.

Foram também estudados os efeitos das variações do regime da deformação sobre o desenvolvimento das OPR da onfacita. As simulações mostram que mudanças no regime da deformação conduzem à variações de segunda ordem no padrão da OPR da onfacita. Estas variações são representadas principalmente por assimetrias em relação ao arcabouço estrutural, concentração alta dos eixos [001] em relação à concentração dos pólos dos planos (010), ou dispersão dos eixos [001] no plano de foliação, e são similares às variações observadas nos eclogitos. Isto sugere que as OPR das onfacitas podem trazer informações sobre alguns parâmetros da deformação dos eclogitos, em particular, a forma do elipsóido de deformação e a existência de uma eventual componente de cisalhamento. Então, pode-se dizer que a onfacita é um mineral importante para decifrar os processos tectônicos ativos sob condições de alta pressão.

Ver artigo "Plastic deformation and development of clinopyroxene lattice preferred orientations in eclogite" no anexo II. 
$\overline{\text { SOLITANVУD SO }}$ 


\section{Capítulo 4.}

\section{Microestruturas e OPR em milonitos granulíticos}

\subsection{Os deslocamentos transpressivos na faixa Ribeira ao sudeste do Brasil}

\subsubsection{Quadro tectônico regional}

A faixa Ribeira (Almeida et al., 1973), no Sudeste do Brasil, formou-se durante a orogênese neoproterozóica brasiliana $(600 \pm 100 \mathrm{Ma})$. Esta cadeia, como inicialmente definida, se estende por cerca de $1000 \mathrm{~km}$ do sul do Estado da Bahia até a fronteira com o Uruguai (Hasui et al., 1975), e atualmente restringe-se à porção sudeste do Brasil. A faixa Ribeira faz parte de um conjunto de faixas móveis de idade neoproterozóica que bordejam o cráton do São Francisco e que foram formadas durante a amalgamação do supercontinente Gondwana (ver Trompette, 1994), Fig. 4.1.

À partir de dados estruturais, petrológicos e geocronológicos, diferentes compartimentos litológicos e/ou tectônicos bem como diferentes modelos evolutivos foram propostos para a faixa Ribeira. Na parte central da faixa (região que engloba os Estados do Rio de Janeiro, Minas Gerais e São Paulo), a qual este estudo se refere, pelo menos três principais associações litológicas foram descritas (Almeida, 2000; Trouw et al., 2000) : um embasamento paleoproterozóico - arqueano retrabalhado, constituído principalmente por ortognaisses migmatíticos e ortogranulitos, uma cobertura vulcano-sedimentar paleoneoproterozóica e granitóides associados com a orogênese brasiliana. Vários autores propuseram uma subdivisão em terrenos imbricados, acrescidos ao cráton do São Francisco (p. ex., Heilbron, 1993; Campos Neto e Figueiredo, 1995; Heilbron et al., 1995). Heilbron et al. (1995) individualizaram três domínios empurrados sobre um domínio autóctone na borda do cráton. O domínio alóctone inferior (Domínio Andrelândia) é constituído por um embasamento ortognáissico de composição tonalítica granodiorítica e de uma cobertura principalmente metassedimentar intensamente dobrada. O domínio alóctone médio (Domínio Juiz de Fora) caracteriza-se por intercalações tectônicas entre as rochas do embasamento metamorfizadas na fácies anfibolito superior (gnaisses com biotita e hornblenda localmente 
migmatíticos) até granulito (enderbitos e charnockitos), e as rochas da cobertura metamorfizadas na fácies anfibolito superior. A cobertura é composta por rochas metassedimentares do mesmo tipo que aquelas encontradas no domínio Andrelândia, com muitas intercalações de quartzito. O domínio alóctone superior (Domínio Paraíba do Sul) é composto por ortognaisses de composição granodiorítica a tonalítica contendo numerosos enclaves de natureza anfibolítica, e por um conjunto supra-crustal conhecido como Grupo Paraíba do Sul. A presença de bancos de quartzito e de lentes calcárias em alternância com gnaisses contendo anfibólios e metapelitos caracteriza este domínio. A parte costeira da faixa Ribeira é constituída por ortognaisses, granitos e metassedimentos de alta temperatura, cuja denominação varia segundo os autores: por exemplo, "Domínio Serra dos Órgãos e Litorâneo" (Machado e Demange, 1994), "Domínio Costeiro" (Machado et al., 1996), “Microplaca Serra do Mar" (Campos Neto e Figueiredo, 1995).

Este domínio costeiro poderia incluir um arco magmático neoproterozóico (o arco magmático Rio Doce, 590-480 Ma, Figueiredo e Campos Netos, 1993; Campos Neto e Figueiredo, 1995). Esta hipótese é baseada na zonação química dos granitóides calcoalcalinos (alcalinidade crescente do sudeste até o noroeste) que é correlacionada com uma subducção em direção ao noroeste. Entretanto, existem divergências acerca da polaridade desta subducção (ver Machado, 1997).

Várias questões subsistem acerca da evolução tectônica da faixa Ribeira. Os mais recentes modelos evolutivos usam uma tectônica em regime transpressivo. Entretanto, a questão da partição da deformação permanece aberta. Alguns autores decompõem a evolução tectônica em vários episódios (ou períodos) (p. ex., Tupinambá, 1999; Heilbron et al., 1995; Almeida, 2000, Trouw et al., 2000). Um episódio pré-colisional, associado com a gênese dos granitóides do "Complexo Rio Negro" entre 630 e 595 Ma (Tupinambá, 1999). Um episódio sin-colisional durante o qual ocorreu o essencial do encurtamento crustal por dobras e empurrões com vergência para o cráton do São Francisco, seguido por uma forte movimentação oblíqua; este episódio é também representado pela produção de um grande volume de granito do tipo S, como aqueles da "Serra das Araras" e do "Rio Turvo" (Machado, 1997). Um episódio de deformação mais tardio (pós-colisional), caracterizado pelo desenvolvimento e/ou reativação de grandes transcorrências dextrais paralelas ou subparalelas a faixa. O redobramento e a ativação dessas zonas de cisalhamento teriam originado uma "megassinforma" cuja charneira estaria localizada nas proximidade do rio Paraíba do Sul (Heilbron et al., 1991; Trouw et al., 2000). Para Ebert e Hasui (1998), a tectônica em regime transpressivo na faixa Ribeira seria composta de uma fase tangencial de baixo ângulo e de 


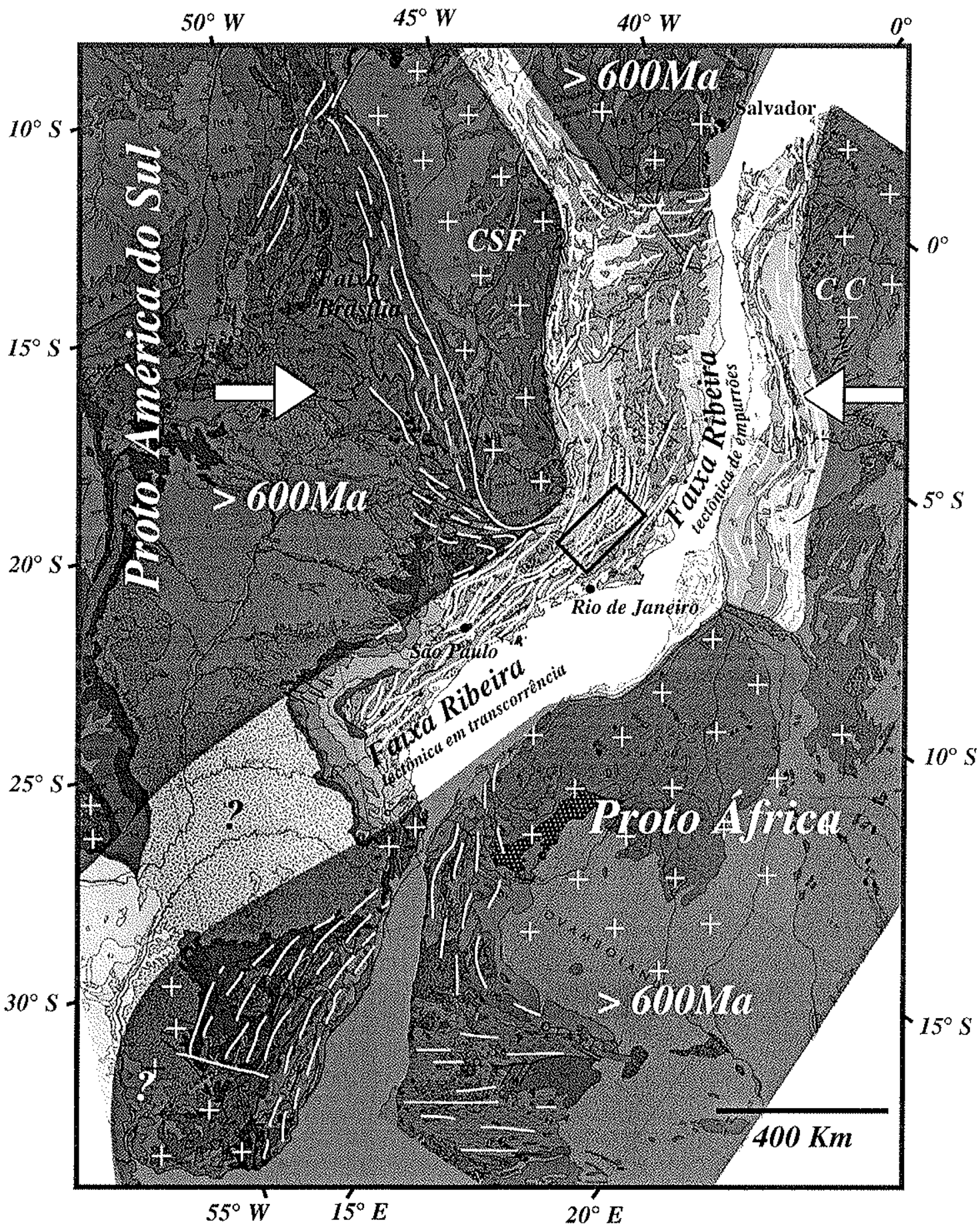

Fig. 4.1. A faixa Ribeira, na borda sudeste do cráton do São Francisco (CSF), no sudeste do Brasil. As faixas neoproterozóicas estão representadas pelos traços brancos espessos. A convergência entre os crátons do São Francisco e do Congo (CC) está indicada pelas duas flechas. Em cinza, está ilustrada a disposição das litosferas continentais estabilizadas antes de $600 \mathrm{Ma}$ (proto América do Sul e proto África (segundo Egydio-Silva et al., 2002). 
direção NW, seguido por uma fase transcorrente de direção NE-SW. Segundo estes autores, a faixa Ribeira ocorre após a formação da faixa Brasília durante colisões diacrônicas entre três blocos crustais (Brasília, São Paulo e Vitória). A obliquaidade da convergência destas placas durante a orogênese teria gerado grandes estruturas em flor positivas tendo como eixo o atual rio Paraíba do Sul. Na parte central da faixa (Estado do Rio de Janeiro), tais estruturas em flor são o resultado de uma tectônica em regime transpressivo e também foram descritas por Corrêa Neto et al. (1993) e Machado e Endo (1993). Os estudos petrográficos e microtectônicos conduzidos por Corrêa Neto e Dayan (1994) concluíram que houve um sincronismo entre o encurtamento e a tectônica em transcorrência. Para Vauchez et al. (1994), a presença de um bloco rígido (o cráton do São Francisco) durante uma colisão leste-oeste seria a causa da tectônica em transpressão ligada ao escape em direção ao sul da parte SE da faixa. A influência da terminação SE do cráton seria a origem das variações do padrão tectono-metamórfico, marcado de norte para sul da faixa por : (i) uma rotação da direção estrutural de N-S à NE-SW, (ii) a passagem de uma tectônica de empurrões (nappes) transversais à faixa para uma tectônica com predomínio das transcorrências paralelas, (iii) uma diminuição do metamorfismo sin-cinemático nas transcorrências dúcteis da fácies granulito até a fácies xisto verde.

Os dados geocronológicos das rochas do embasamento da parte central da faixa Ribeira indicam idades antigas (> 1.5 Ga). Idades transamazônicas (2.3-2.1 Ga) foram obtidas por Söllner et al. (1991), Machado et al. (1996) e Valladares (1996) pelo método U-Pb, e também por Figueiredo e Teixeira (1996) pelo método Rb-Sr. Machado et al. (1996) obtiveram também uma idade U-Pb arqueana ( $>2.8 \mathrm{Ga}$ ) em gnaisse. Brueckner et al. (2000) apresentam idades $\mathrm{Sm}-\mathrm{Nd}$ entre 2.0-1.6 Ga para área central da faixa Ribeira e idades arqueanas $(>2.6 \mathrm{Ga})$ e transamazônicas $(2.3-2.1 \mathrm{Ga})$ para os terrenos mais a leste, no limite do cráton do São Francisco. O limite entre esses terrenos de idades distintas poderia corresponder à descontinuidade de Abre Campo, uma importante anomalia gravimétrica e magnética (Haralyi e Hasui, 1982). Segundo Pedrosa-Soares et al. (1998), a associação espacial destes anomalias com rochas meta-ultramáficas indica vestígios de uma antiga crosta oceânica.

As rochas da parte central da faixa Ribeira registram um importante evento tectonotérmico datado por Machado et al. (1996) em 590-565 Ma, à partir das análises U.-Pb em zircões, monazita e titanita. Idades brasilianas similares foram obtidas por Söllner et al. (1991) para as rochas do domínio Juiz de Fora (método U-Pb em zircões). Estas idades são associadas com a tectônica tangencial em direção do cráton e ao desenvolvimento das zonas 
de cisalhamento dextrais. No domínio Paraíba do Sul e Costeiro, idades U-Pb mais recentes, entre 535-528 Ma, obtidas por Machado et al., (1996) são associadas à reativação de antigas estruturas e ao desenvolvimento de novas transcorrências dextrais. As rochas da região de Búzios (NE do Rio de Janeiro), que registram idades em torno de $520 \mathrm{Ma}$ (idade U-Pb em monazita de metapelito), poderiam representar o fim da amalgamação do Gondwana (Schmitt et al., 1999).

\subsubsection{Zonas de cisalhamento de alta temperatura : o sistema Além Paraíba} - Pádua

\subsubsection{Localização}

Os domínios central e sul da faixa Ribeira são caracterizados por zonas de cisalhamento que afloram ao longo desta faixa por várias centenas de quilômetros (Fig. 4.2). A maior delas é a zona de cisalhamento Além Paraíba (Fig. 4.3), também chamada "lineamento de Além Paraíba" por Almeida et al. (1975), por causa do seu traçado quase retilíneo, evidenciado pelo rio Paraíba do Sul. Este lineamento já foi interpretado por Almeida e colaboradores como uma grande falha profunda, do tipo transcorrente dextral. Posteriormente, trabalhos visando caracterizar a geometria e a cinemática desta zona de cisalhamento foram realizados no Estado do Rio de Janeiro por diversos autores (p. ex., Brenner et al., 1980; Campanha, 1981; Dayan e Keller, 1990; Corrêa Neto et al., 1993; Almeida, 2000).

No noroeste do Estado do Rio de Janeiro, a zona de cisalhamento de Além-Paraíba, retilínea e de direção N070 até a cidade de Além Paraíba, evolui para o nordeste em um conjunto de transcorrências dextrais de direção N030 (Fig. 4.3b). Este conjunto de falhas dúcteis, paralelas às orientações tectônicas regionais, constitui o sistema de zonas de cisalhamento de Além Paraíba - Pádua ("Além Paraíba-Pádua Shear zone System”, (EgydioSilva et al., 2002). A zona de cisalhamento de Além-Paraíba é ligeiramente oblíqua sobre a direção regional (ver por exemplo, Fig. 4.2); ela é interpretada como uma banda de cisalhamento C' de grande escala que atuou como uma falha de transferência que acomoda a componente de contração normal ao orógeno em um regime transpressivo (Egydio-Silva et al., 2002). 


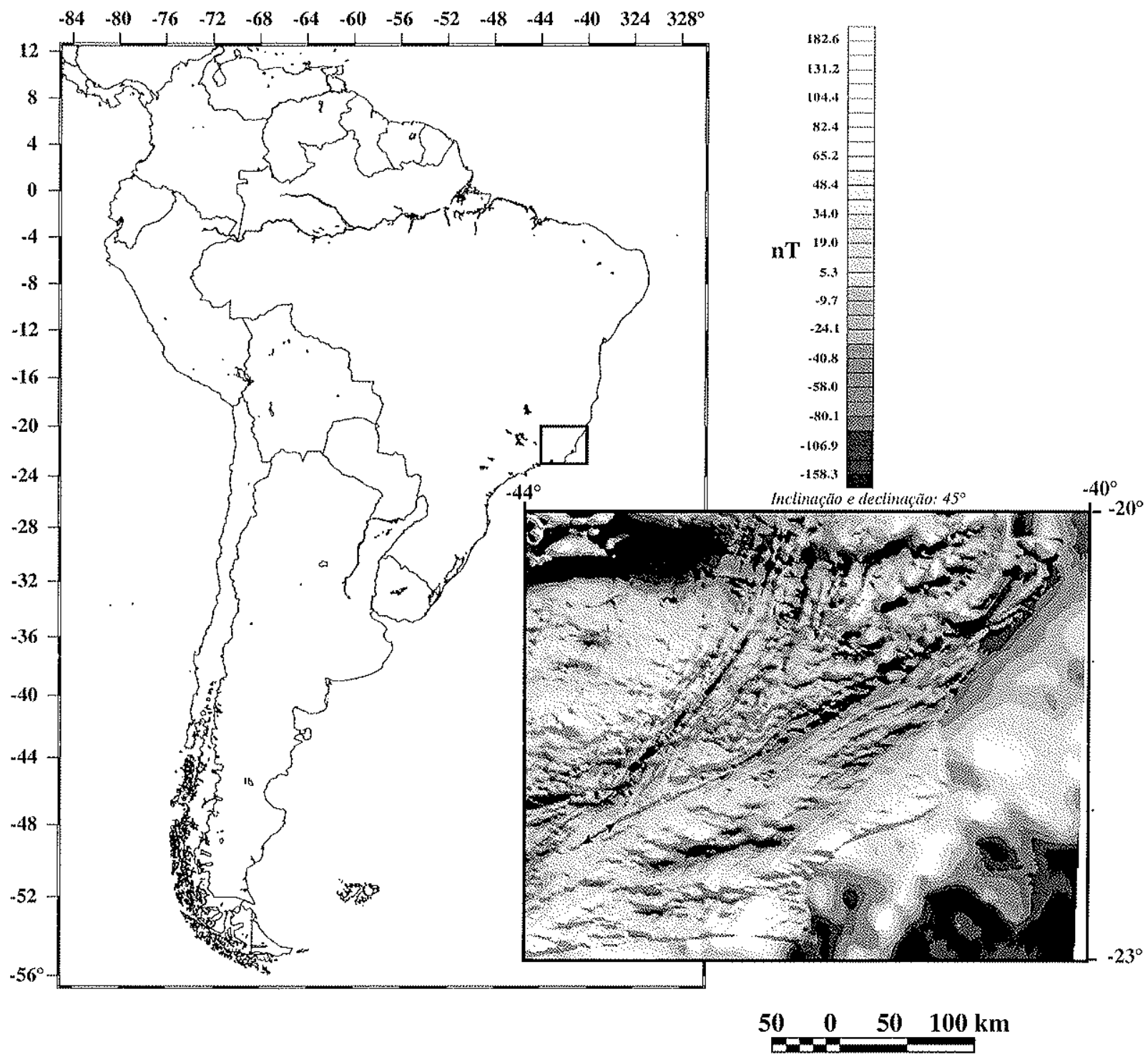

Fig. 4.2. Mapa aeromagnético do sudeste do Brasil (projeto Brasil - Alemanha, DIGEOF CPRM). As anomalias orientadas NE correspondem às grandes zonas de cisalhamento da faixa Ribeira. A flecha $(\leftrightarrow$ ) está localizada sobre a zona de cisalhamento Além Paraíba, ao sudoeste de Três Rios. 

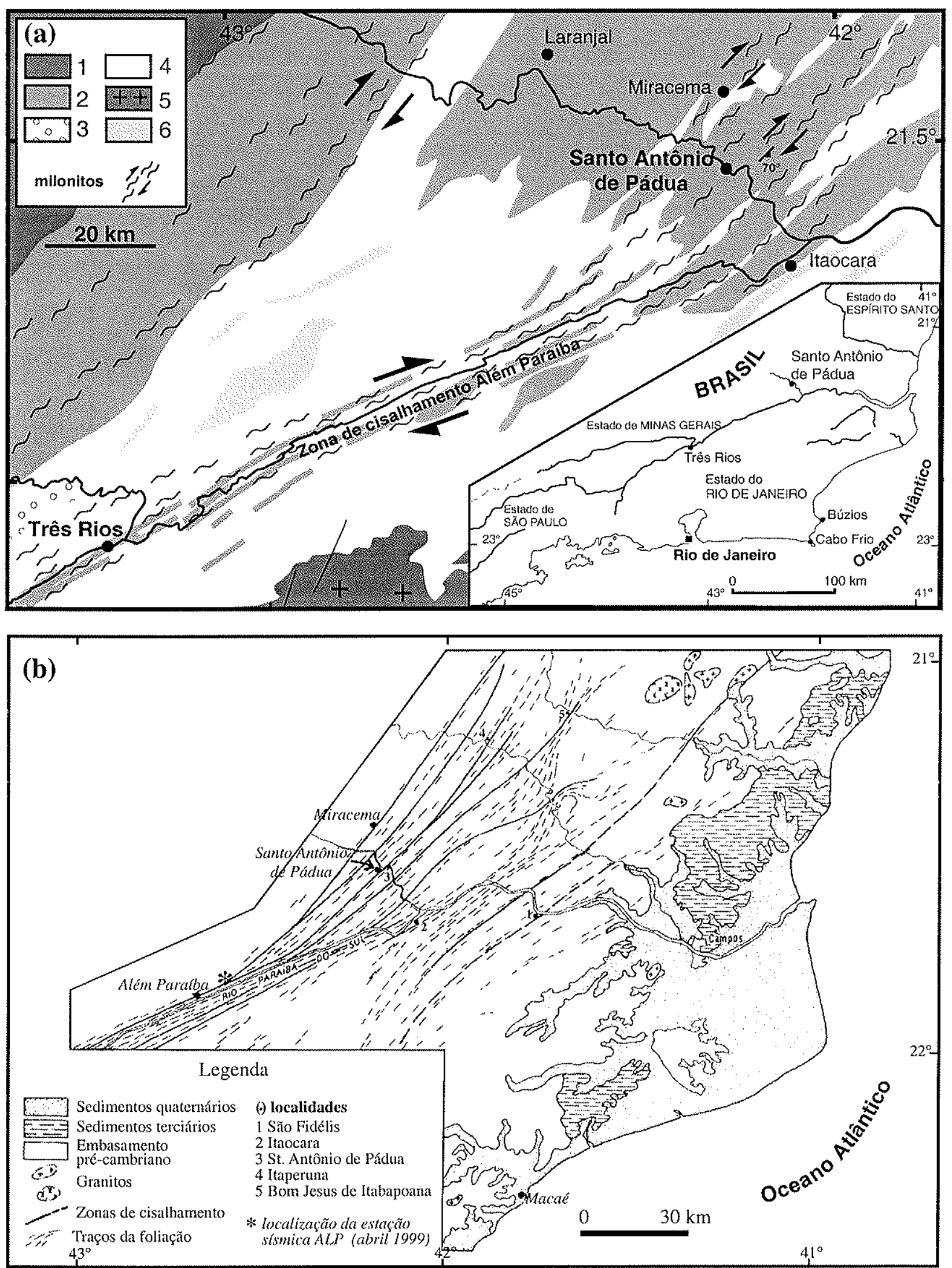

Fig. 4.3. As zonas de cisalhamento na faixa Ribeira.

(a) Mapa geológico esquemático e localização das principais zonas de cisalhamento. 1) Embasamento indiferenciado, 2) granulitos e charnockitos (Complexo Juiz de Fora), 3) enderbitos, 4) gnaisses e migmatitos (Complexo Paraíba do Sul), 5) granitos sintectônicos, 6) mármores (Grupo Italva), (fonte: mapa geológico 1/1.000.000, projeto RADAMBRASIL, 1983);

(b) Principais zonas de cisalhamento da região NE do estado do Rio de Janeiro (região adjacente aos estados de Minas Gerais e Espírito Santo), (segundo Brenner et al., 1980). 


\subsubsection{O perfil de Miracema-Itaocara: as estruturas}

Uma amostragem sistemática foi realizada na região de Santo Antônio de Pádua, entre as cidades de Miracema e Itaocara (Fig. 4.4). A localização deste perfil foi escolhida em função do rio Pomba, que permite a observação de excelentes afloramentos quando o seu volume de água está baixo. O curso do rio, bem como uma estrada, tornam os afloramentos acessíveis e são orientados perpendicularmente à direção das estruturas. Além disso, esta zona apresenta um grande número de pedreiras em atividade constituindo, assim a principal fonte dos afloramentos.

$\mathrm{Na}$ escala de afloramento, as estruturas tectônicas (foliação e lineação) são bem marcadas. A foliação, as vezes salientada por um bandamento composicional, apresenta um forte mergulho para sudeste. Entre Miracema e Itaocara, o mergulho da foliação é relativamente constante (cerca de $70^{\circ} \mathrm{SE}$ ). Ao norte de Miracema, o mergulho da foliação diminui progressivamente, atingindo $40^{\circ} \mathrm{SE}$ perto de Laranjal (localização Fig. 4.3a). No campo, a lineação nem sempre é fácil de ser observada. Uma lineação mineral sub-horizontal é marcada pelo alongamento dos cristais (anfibólios, ortopiroxênios, óxidos..., Fig. 4.5b) ou por agregados de minerais alongados e uma boudinage (muitas vezes dos níveis de composição máfica), o que mostra que o estiramento está associado à lineação mineral. Os afloramentos perpendiculares as estruturas mostram dobras isoclinais cujos eixos são subhorizontais, paralelos à lineação mineral (Fig. 4.5c).

Nos milonitos, os principais indicadores cinemáticos, caudas de recristalização assimétricas, fábricas planares S-C, bandas de cisalhamento..., sugerem um sentido de cisalhamento dextral (Fig. 4.5d). Os indicadores cinemáticos mais freqüentemente observados são as caudas de recristalização em porfiroclastos de feldspato ("mantled porphyroclasts") que formam predominantemente sistemas do tipo $\sigma$ (Passhier, 1994), embora sistemas do tipo $\delta$ também tenham sido observados. Entretanto, um grande número de caudas de recristalização encontra-se sob forma simétrica. Nestas rochas de alto grau, a dissimetria das estruturas poderia ser mascarada por processos de "annealing" pós-tectônico a alta temperatura (EgydioSilva et al., 2002). Uma deformação em transpressão poderia também impedir o desenvolvimento de estruturas assimétricas (p. ex., Vauchez et al., 1995).

Em algumas pedreiras (RB614, RB684, Fig. 4.4), as rochas observadas são caracterizadas por uma foliação milonítica, dobras e ausência de lineação. A deformação destes afloramentos reflete um encurtamento horizontal NW-SE. Portanto, na região de Santo 
Antônio de Pádua, as estruturas dos milonitos testemunham uma partição da deformação, com afloramentos cuja deformação está associada a uma transcorrência dextral, e outros cuja deformação é compatível com uma compressão coaxial.

Em toda a região de estudo, a deformação é forte e a foliação bem desenvolvida. Entretanto, alguns afloramentos não mostram nem foliação e nem lineação. É o caso, por exemplo, de grandes maciços da série charnockítica (RB689). A textura granoblástica destas rochas impede a medida de um eventual plano de achatamento preferencial. Por outro lado, alguns afloramentos granulíticos têm uma aparência migmatítica e os líquidos quartzo feldspáticos injetados na rocha (Fig. 4.5e) tornam difíceis a observação e a medida da foliação.

4.1.2.3. O perfil Miracema-Itaocara: natureza dos afloramentos e dados de pressão-temperatura

\section{Natureza dos afloramentos}

Ao contrário das estruturas tectônicas, a litologia dos afloramentos é muito heterogênea ao longo do perfil apresentando rochas da série charnockítica, migmatitos, gnaisses e granulitos. Nesta sessão, são apresentados alguns dos afloramentos típicos cujas amostras foram objeto de um estudo detalhado das microestruturas e da medida das OPR. As análises químicas das diferentes fases minerais e as abreviaturas dos minerais são apresentadas no apêndice II.

Na região de Miracema, ao norte do perfil, (Fig. 4.4) afloram granulitos ricos em minerais ferro-magnesianos com filões centrimétricos de composição granítica. A proporção de leucossoma granítico na rocha é variável. A amostra RB546 é um desses granulitos cujas principais fases minerais são : Pl (An) - Qtz - Bt - Opx (Hyp) - Grt. As camadas feldspáticas, o quartzo em fita ("ribbons"), a granada e os porfiroclastos alongados de ortopiroxênio (de comprimento pluri-milimétrico) salientam a foliação. Pequenos grãos arredondados de orto- e de clinopiroxênio $(<100 \mu \mathrm{m})$ são igualmente observados. O plagioclásio está intensamente recristalizado e os neoblastos têm um tamanho de cerca de $300 \mu \mathrm{m}$.

Ao norte do perfil, gnaisses enderbíticos (ver a série dos charnockitos no apêndice II), cujo caráter plutônico é ainda reconhecível, são abundantes. A amostra RB559, mesocrática, é rica em hiperstênio e hornblenda; cada um deste dois minerais constitui cerca de $15 \%$ da composição modal da rocha. Ortopiroxênio e clinopiroxênio estão em equilíbrio nesta rocha. 
O plagioclásio apresenta uma zonação magmática clara (Fig. 4.12b). A foliação é definida pela forma alongada dos grãos de plagioclásio, que possuem um tamanho maior (cerca de 750 $\mu \mathrm{m})$ do que as outras fases minerais (cerca de $500 \mu \mathrm{m}$ ).

Entre as cidades de Miracema e Santo Antônio de Pádua, os milonitos apresentam composições mineralógicas contrastantes. Por exemplo, alguns possuem uma composição granítica isenta de ortopiroxênio (amostras RB614 e RB684). Estes gnaisses leucocráticos, finamente pontilhados por anfibólios de comprimento milimétrico, contêm grãos centimétricos de feldspatos potássico, titanita, zircão, alanita e clinozoisita. Estes afloramentos são caracterizados por uma foliação penetrativa que destaca a bitotita e o anfibólio e por uma ausência de lineação. Outros afloramentos são constituídos por granulitos com granada e biotita. As granadas de tamanho centimétrico são muitas vezes poiquilíticas. A foliação é marcada pela biotita e por camadas quartzo-feldspáticas de largura milimétrica, e a lineação pelo alongamento dos porfiroclastos de ortopiroxênio e dos grãos de ilmenita.

A zona de cisalhamento de Santo Antônio de Pádua (Fig. 4.4) é caracterizada pela presença de milonitos bandados (Fig. 4.5a). Este bandamento corresponde a uma alternância de camadas básicas ricas em ortopiroxênio, anfibólio e ilmenita, cujo alongamento define a lineação, e de camadas mais félsicas, de cor rosada, de composição granítica (amostra $\mathrm{RB} 609 \mathrm{c})$. Ao longo do perfil, variações de composição das camadas básicas e félsicas são observadas. Por exemplo, para o sítio RB538, as camadas apresentam uma composição granodiorítica, enquanto que as rochas do afloramento RB540 são ricas em ortopiroxênio e óxidos de Fe-Ti (ilmenita particularmente) que definem a lineação. Camadas ricas em granada, ortopiroxênio muito deformado (Fig. 4.15c) e biotita também são observadas (RB607B).

Ao sul do perfil, entre Santo Antônio de Pádua e Itaocara, encontram-se novamente maciços da série dos charnockitos com textura granoblástica (RB689 e RB690). Ao sul destes corpos intrusivos, perto da cidade de Itaocara, voltam a aflorar milonitos cuja foliação tem direção N055 e são paralelos ao rio Paraíba do Sul (Fig. 4.4). O metassedimento RB566 é um desses milonitos com muita hornblenda e biotita. Esta amostra apresenta plagioclásios ricos em cálcio (bitownita), carbonatos de cálcio, dois tipos de anfibólio (actinolitas - hornblendas (P48') e anfibólios mais aluminosos e menos magnesianos que os primeiros (P48)), granadas, e micas que possuem uma composição de flogopita (apêndice II). 


\section{Estimativas das condições de Pressĩo - Temperatura}

Apesar dos numerosos trabalhos de petrografia sobre a faixa Ribeira, poucos dados de termobarometria foram publicados. Porcher et al. (1995) determinaram as pressões e temperaturas em três amostras, duas coletadas na região de Três Rios e a terceira entre Miracema e Santo Antônio de Pádua (localização ao nível do afloramento RB5, Fig. 4.4.). Esta última amostra é um granulito milonitizado com uma foliação (N045E-65SE) e uma lineação (60-N110) bem marcadas e de composição qtz + pl + bt + grt + opx + ilm \pm hbl. Para esta amostra, o termômetro granada-biotita de Ferry e Spear (1978) indica temperaturas entre $717^{\circ}$ e $776^{\circ} \mathrm{C}$ e aquele de Hodges e Spear (1982) entre $783^{\circ}$ e $839^{\circ} \mathrm{C}$. Estas temperaturas são associadas ao pico de metamorfismo na região de Santo Antônio de Pádua. As pressões calculadas são relativamente baixas: $\leq 700 \mathrm{MPa}$ (Porcher et al., 2000).

Como o número de dados de termobarometria nesta região é muito escasso, uma parte das análises químicas realizadas para subsidiar as medidas de EBSD foi utilizada para ajustar as condições de P-T dos milonitos. Diferentes geotermômetros foram aplicados a nossas amostras : o geotermômetro granada - biotita, o geotermômetro ortopiroxênio clinopiroxênio, o geotermômetro hornblenda - plagioclásio.

O geotermômetro granada - biotita. Este geotermômetro tem como base as trocas Fe$\mathrm{Mg}$ entre a granada e a biotita e foi empregado para avaliar as condições P.T de duas amostras: RB685 e RB607B. A amostra RB685 tem como paragênese metamórfica : qtz + pl + grt + bt + ilm. A granada é poiquiloblástica e apresenta inclusões de quartzo e biotita. As micro-análises relevam uma variação de $\mathrm{Fe}$ e $\mathrm{Mg}$ entre o centro e a borda da granada, o que traduz um enriquecimento em $\mathrm{Fe}$ em relação ao $\mathrm{Mg}$. As temperaturas obtidas à partir dos centros da granada et da biotita variam entre $700^{\circ}$ e $780^{\circ} \mathrm{C}$ segundo a calibragem de Ferry e Spear (1978), e entre $780^{\circ}$ e $809^{\circ} \mathrm{C}$ segundo a calibragem de Hodges e Spear (1982), enquanto as medidas na borda das granadas mostram uma diminuição das temperaturas em dezenas de graus Célsius. Os cálculos são efetuados considerando uma pressão de $500 \mathrm{MPa}$. A amostra RB607B apresenta assembleias de granada - biotita - ortopiroxênio. As temperaturas obtidas à partir de três medidas da granada e de uma biotita ao contato variam entre $814^{\circ}$ e $874^{\circ} \mathrm{C}$ segundo a calibragem de Ferry e Spear (1978), e entre $867^{\circ}$ e $905^{\circ} \mathrm{C}$ segundo a calibragem de Hodges e Spear (1982) considerando-se uma pressão de $500 \mathrm{MPa}$. Para pressões de $600 \mathrm{MPa}$, as temperaturas calculadas sao similares às temperaturas calculadas para uma pressão de $500 \mathrm{MPa}$. O número reduzido de medidas selecionadas para este tipo de avaliação termobarométrica exige cautela na utilização dos resultados. Entretanto, 
as temperaturas obtidas são equivalentes ou ligeiramente superiores àquelas obtidas por Porcher et al. (1995).

O geotermômetro ortopiroxênio - clinopiroxênio (Wells, 1977). As temperaturas estimadas para a amostra enderbítica RB559 à partir das análises de um clinopiroxênio e de três ortopiroxênios (apêndice II) estão em torno de $980^{\circ} \mathrm{C}$.

O geotermômetro hornblenda - plagioclásio. Este termômetro desenvolvido por Blundy e Holland (1990) tem como base o teor de Al nas hornblendas coexistentes com o plagioclásio para as rochas saturadas. Calculou-se de modo sistemático as temperaturas a partir deste termômetro, emitindo a hipótese de que, nestas rochas intensamente deformadas em alta temperatura, um equilíbrio químico ocorreu entre a hornblenda e o plagioclásio. Os anfibólios das amostras RB559, RB614, RB609A, RB484 e RB607A são relativamente homogêneos. Nos milonitos, o plagioclásio foi amplamente recristalizado durante a deformação. As temperaturas mínimas obtidas são superiores à $740^{\circ} \mathrm{C}$ (Fig. 4.6a) e a temperatura máxima tem uma valor de $930^{\circ} \mathrm{C}$ (enderbito RB559). Para esta amostra, as temperaturas calculadas pelo geotermômetro hornblenda - plagioclásio estão de acordo com as altas temperaturas determinadas pelo termômetro ortopiroxênio - clinopiroxênio. Para a $\mathrm{RB} 559$, o intervalo entre os valores de $\mathrm{T}^{\circ}$ máx e $\mathrm{T}^{\circ}$ mín é relativamente importante $\left(67^{\circ} \mathrm{C}\right)$ devido essencialmente às variações químicas do plagioclásio. Pelo outro lado, as variações entre os valores $\mathrm{T}^{\circ}$ máx e $\mathrm{T}^{\circ}$ mín para as outras amostras são pequenas $\left(<40^{\circ} \mathrm{C}\right)$, o que parece validar a hipótese do equilíbrio das reações entre o plagioclásio e o anfibólio.

Nos milonitos, as temperaturas avaliadas empregando-se diferentes geotermômetros bem como as análises de $\mathrm{Ti}$ e $\mathrm{Al}^{\mathrm{VI}}$ em biotitas (diagrama de Schreur, Fig. 4.6b) são superiores à $750^{\circ} \mathrm{C}$. Estas temperaturas são típicas da fácies granulito.

As condições barométricas foram mais difíceis de serem avaliadas. Os cálculos de pressão na amostra RB607B feitos a partir das análises em granada e ortopiroxênio (Harley e Green, 1982; Brey e Kohler, 1990) indicam importantes variações para os valores de pressão. Para as temperaturas que variam entre $800^{\circ}$ e $900^{\circ} \mathrm{C}$, a pressão P estimada é $500 \leq \mathrm{P}(\mathrm{MPa}) \leq 900$. 


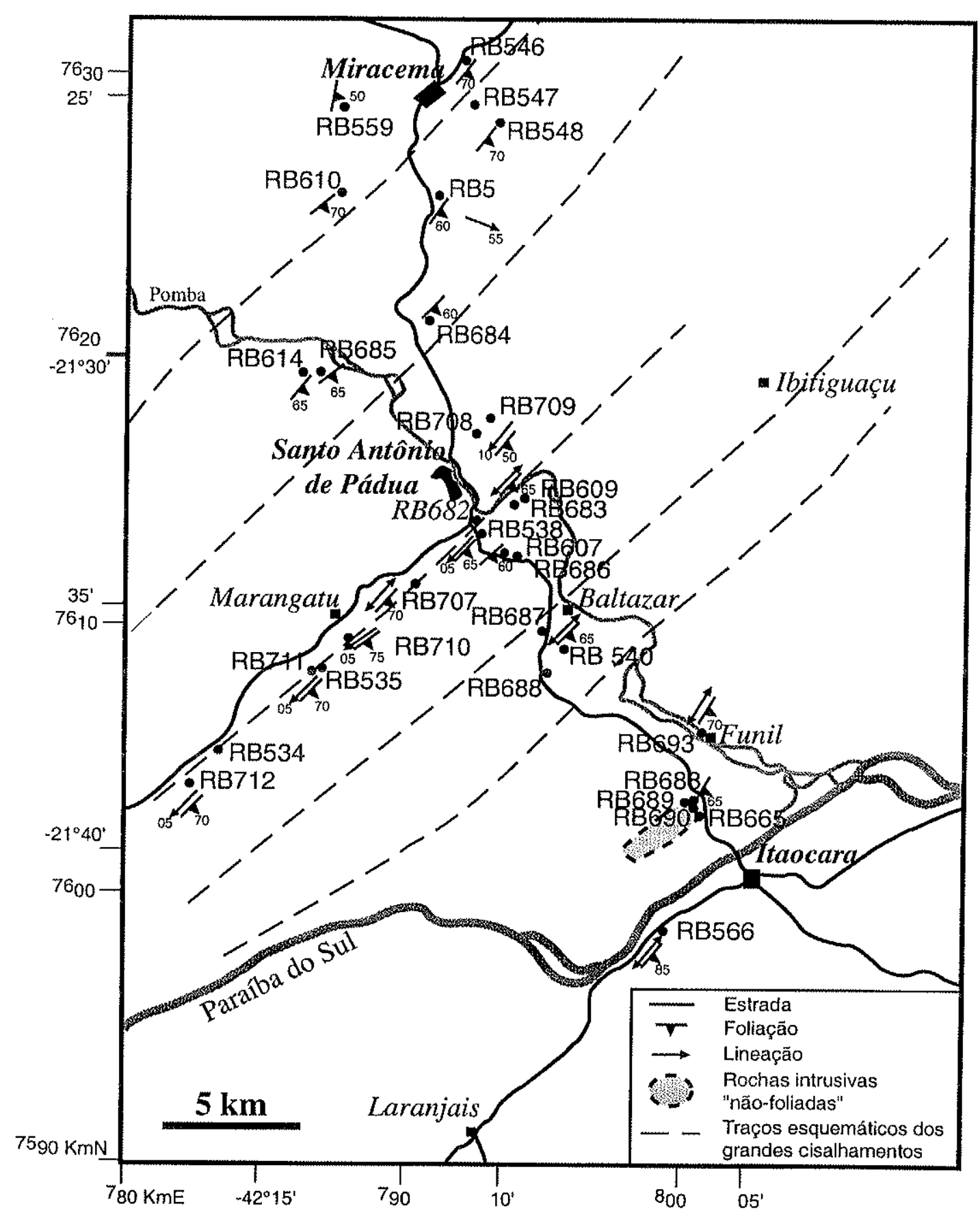

Fig. 4.4. Localização dos principais afloramentos estudados. 

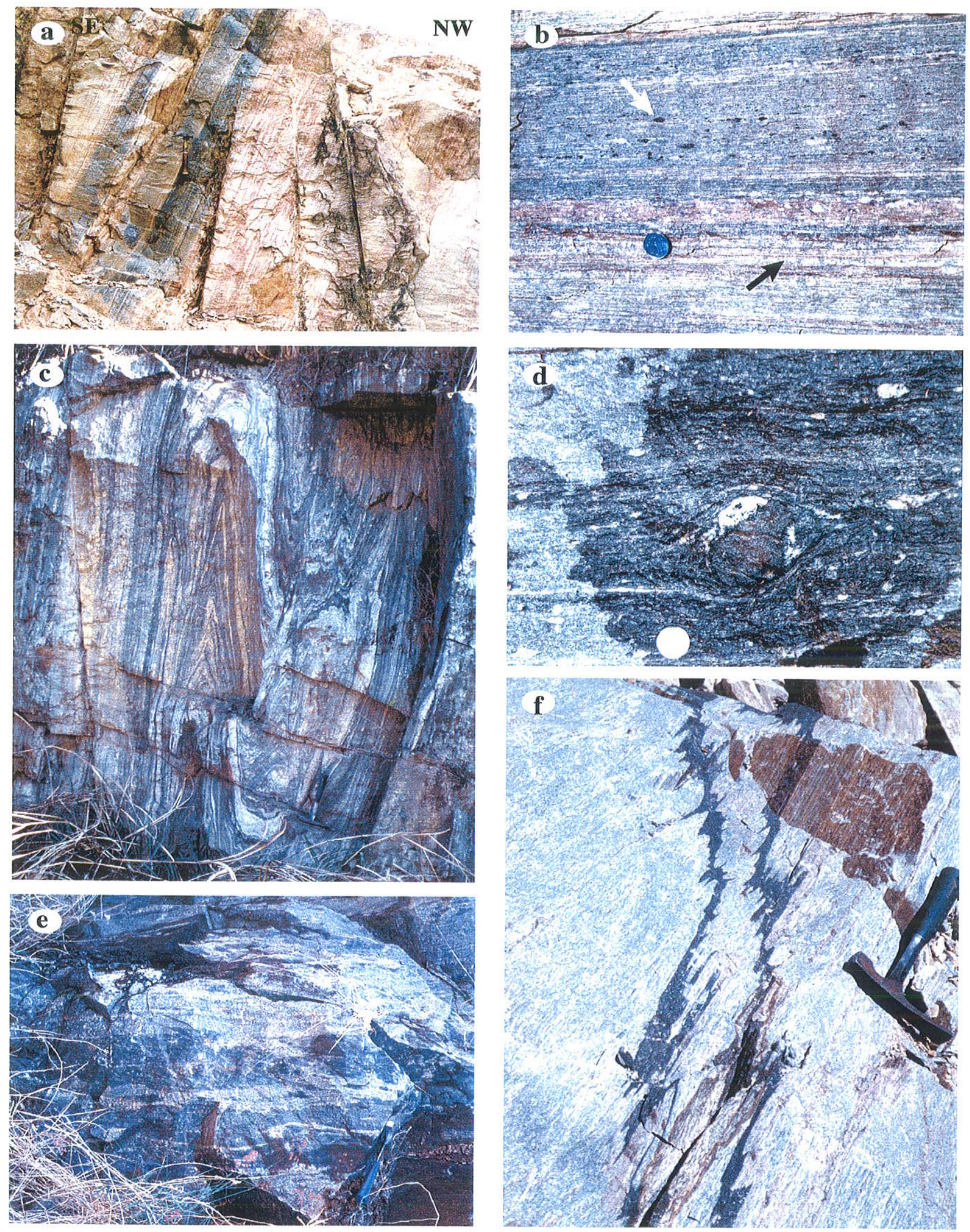

Fig. 4.5. Afloramentos na região de Santo Antônio de Pádua. (a) Milonitos bandados (RB609); (b) Detalhe de (a), alternância de camadas (bandas) básicas ricas em anfibólios (flecha branca) e bandas félsicas de coloração roséa. O quartzo forma "ribbons" policristalinos (flecha preta); (c) Dobras isoclinais; (d) Inclusão de anfibolito de forma elíptica mostrando uma assimetria característica de movimentação dextral; (e) Granulitos injetados por filões quartzo-feldspáticos; (f) Filões básicos intensamente dobrados. 
(a)

\begin{tabular}{|lllllcc|}
\hline Amostra & $\begin{array}{l}\mathrm{T}^{\circ} \mathrm{mín} . \\
500 \mathrm{MPa}\end{array}$ & $\begin{array}{c}\mathrm{T}^{\circ} \mathrm{máx} . \\
500 \mathrm{MPa}\end{array}$ & $\begin{array}{c}\mathrm{T}^{\circ} \mathrm{mín} . \\
600 \mathrm{MPa}\end{array}$ & $\begin{array}{c}\mathrm{T}^{\circ} \mathrm{máx} . \\
600 \mathrm{MPa}\end{array}$ & $\begin{array}{c}\text { Medidas } \\
\text { no Pl }\end{array}$ & $\begin{array}{c}\text { Medidas } \\
\text { no Anf }\end{array}$ \\
\hline RB559 & $867^{\circ} \mathrm{C}$ & $932^{\circ} \mathrm{C}$ & $850^{\circ} \mathrm{C}$ & $914^{\circ} \mathrm{C}$ & 9 & 6 \\
RB614 & $850^{\circ} \mathrm{C}$ & $887^{\circ} \mathrm{C}$ & $834^{\circ} \mathrm{C}$ & $870^{\circ} \mathrm{C}$ & 5 & 5 \\
RB609A & $741^{\circ} \mathrm{C}$ & $763^{\circ} \mathrm{C}$ & $726^{\circ} \mathrm{C}$ & $748^{\circ} \mathrm{C}$ & 2 & 8 \\
RB484 & $816^{\circ} \mathrm{C}$ & $829^{\circ} \mathrm{C}$ & $800^{\circ} \mathrm{C}$ & $812^{\circ} \mathrm{C}$ & 5 & 5 \\
RB607A & $859^{\circ} \mathrm{C}$ & $878^{\circ} \mathrm{C}$ & $842^{\circ} \mathrm{C}$ & $861^{\circ} \mathrm{C}$ & 2 & 10 \\
\hline
\end{tabular}

(b)

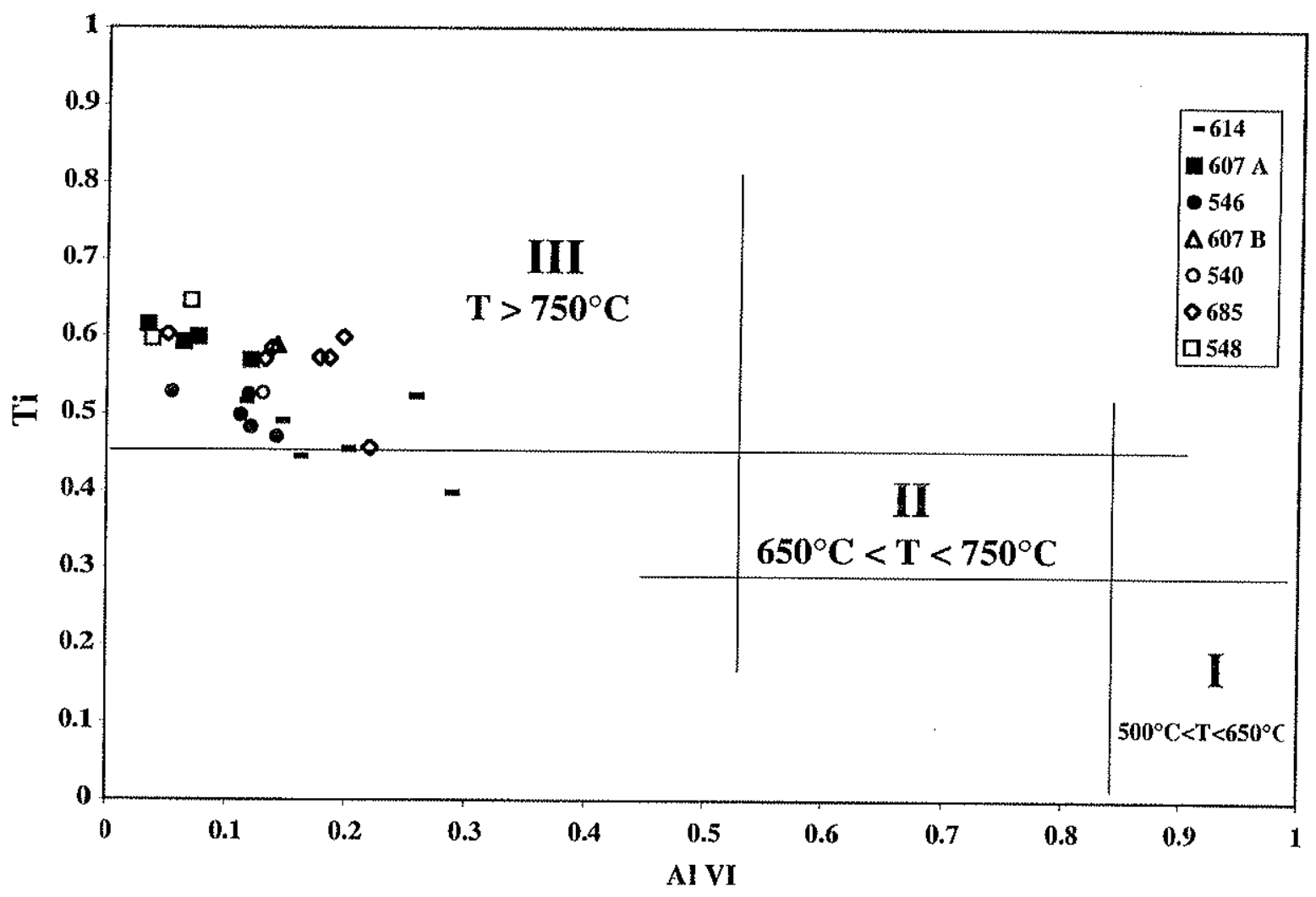

Fig. 4.6. Cálculo das condições P-T. (a) Temperaturas determinadas a partir do geotermômetro plagioclásio - anfibólio (Blundy e Holland, 1990); (b) Diagrama de Schreur. I, II, III são os domínios das temperaturas em função do conteúdo em Ti e AIVI das biotitas. 
Uma grande diversidade litológica é observada ao longo do perfil. Entretanto, os afloramentos apresentam características comuns :

- as litologias quartzo-feldspáticas principalmente estão em equilíbrio na fácies dos granulito. Ortopiroxênio (hiperstênio), clinopiroxênio e granada estão frequientemente associados ao quartzo e ao feldspato. Muitas vezes biotita e anfibólio estão presentes, entretanto granulitos anidros também podem ser observados. Óxidos de Fe-Ti, particularmente ilmenita, e também magnetita, são observados em um grande número de amostras,

- as estruturas tectônicas são penetrativas. A foliação definida pela organização dos minerais é muitas vezes marcada por um bandamento composicional. Ao longo do perfil, o plano de foliação tem uma orientação relativamente constante, em média N040E-65SE. A lineação definida pelo alongamento e pelo alinhamento de minerais (anfibólio, ortopiroxênio, óxidos) é geralmente sub-horizontal. Nas zonas de cisalhamento da região de Santo Antônio de Pádua, a deformação resulta da combinação de um componente coaxial associado à um encurtamento horizontal NW-SE, e de um componente não-coaxial originando grandes transcorrências dextrais. O campo da deformação finita é característico de um regime transpressivo.

Os dados petrológicos, estruturais e microestruturais levantados dos afloramentos estudados evidenciam uma milonitização sob fácies granulito associada com a ativação de grandes transcorrências transpressivas. As rochas da região de Santo Antônio de Pádua apresentam as condições ideais para o estudo dos mecanismos de deformação ativos sob condições de alta temperatura. 


\subsection{Microestruturas e OPR}

\subsubsection{O quartzo}

\subsubsection{Estrutura e deformação plástica}

$\mathrm{O}$ quartzo, $\mathrm{SiO}_{2}$, é um silicato com uma estrutura tridimensional formada de tetraedros $\mathrm{SiO}_{4}$. A pressão ambiente e até a uma temperatura de $573^{\circ} \mathrm{C}$, o quartzo $\alpha$ apresenta uma estrutura de simetria romboédrica. Acima de $573^{\circ} \mathrm{C}$, o quartzo- $\beta$ apresenta uma estrutura de simetria hexagonal. A coesita, de simetria monoclínica, é a forma de alta pressão do $\mathrm{SiO}_{2} . \mathrm{O}$ domínio de estabilidade das principais fases do $\mathrm{SiO}_{2}$ é indicado na Fig. 4.7a. O deslizamento intracristalino no quartzo requer a ruptura de ligações covalentes $\mathrm{Si}-\mathrm{O}$ muito fortes. $\mathrm{O}$ deslizamento torna-se possível pela presença de água em traços dentro do cristal (Blacic, 1975 ) enquanto que o quartzo anidro poderia se deformar somente através do mecanismo de geminação (ver revisão em Nicolas e Poirier, 1976).

As geminações (ou maclas) de origem mecânica mais frequente do quartzo são a geminação de Dauphiné e a geminação do Brasil. A geminação de Dauphiné, frequente no quartzo $\alpha$, corresponde à uma rotação da rede de $180^{\circ}$ em volta do eixo-c. Os planos de geminação são paralelos à (10T1) e (10 T̄0), o sentido da hélice do eixo-c é conservada, os eixos cristalográficos conservam suas orientações, mas a polaridade dos eixos-a é invertida. Ao contrário da geminação de Dauphiné, a geminação do Brasil provoca a ruptura das ligações Si-O-Si e muda o sentido da hélice do eixo-c por simetria de plano $\{11 \overline{2} 0\}$. A geminação do Brasil foi observada por MET em monocristais de quartzo naturalmente deformados a temperatura relativamente baixa $\left(500^{\circ} \mathrm{C}\right)$, a uma velocidade de deformação alta, e para esforços tangenciais importantes sobre o plano (0001).

A importância do deslizamento intracristalino na deformação plástica do quartzo foi demonstrada através dos trabalhos de microscopia eletrônica (p. ex., Christie e Ardell, 1974) bem como através de trabalhos acerca da deformação experimental (p. ex., Tullis et al., 1973; Mainprice e Paterson, 1984). Para temperaturas relativamente baixas (a partir de $300-400^{\circ} \mathrm{C}$ ) e taxas de deformação relativamente baixas, o deslizamento basal nas direções <a> (sistema $(0001)<11 \overline{2} 0>$ ) é facilmente ativado. Em condições de temperaturas médias e altas (400 $700^{\circ} \mathrm{C}$ ), o deslizamento prismático $\{\mathrm{m}\}$ nas direções $<\mathrm{a}>($ sistema $\{10 \overline{1} 0\}<11 \overline{2} 0>$ ) torna-se significativo. Para temperaturas muito altas (acima de $700-800^{\circ} \mathrm{C}$ ), o deslizamento 
prismático $\{\mathrm{m}\}$ na direção $[\mathrm{c}] \mathrm{e}<\mathrm{a}+\mathrm{c}>$ torna-se muito ativo. $\mathrm{O}$ deslizamento prismático pode também ser acompanhado por urn deslizamento sobre os planos piramidais.

O desenvolvimento de uma orientação preferencial de rede é controlado por (1) os sistemas de deslizamento que ocorrem durante a deformação plástica do quartzo; (2) a magnitude e a simetria da deformação finita; e (3) a história cinemática (ver Schmid e Casey, 1986). A influência desses fatores sobre o desenvolvimenta das OPR do quartzo foi demonstrada através de estudos experimentais (Tullis et al., 1973; Dell'Angelo e Tullis, 1989) e por simulações numéricas de deformação plástica (Lister et al., 1978; Etchecopar e Vasseur, 1987; Wenk et al., 1989). Nas OPR do quartzo deformado naturalmente, é extremamente difícil isolar a contribuição desses diferentes fatores. Além disso, a maioria dos trabalhos enfoca o eixo-c do quartzo que é o único eixo cristalográfico cuja orientação pode ser medida com a platina universal. Medidas do eixo-c do quartzo na escala regional, como nos terrenos granulíticos de Saxony (Lister e Dornsiepen, 1982), evidenciaram numerosas variações do padrão de eixo-c. Esses diferentes padrões são ligados às variações dos diferentes parâmetros acima citados (atividade dos sistemas de deslizamento, regime da deformação,...). Entretanto, a orientação de só eixo só (o eixo-c) restringe a informação. Há casos em que estas orientações não são esclarecedoras, por exemplo, os padrões do eixo-c com um máximo à $45^{\circ}$ entre os eixos X e Z (posição III de Lister, 1982). Esta orientação preferencial foi interpretada como resultando de um deslizamento sobre os planos romboidais (Starkey, 1979), como resultando da ativação dominante de sistemas dipiramidais trigonais $\{2 \overline{1} 12\}<c+a>$ (Lister e Dornsiepen, 1982), ou ainda como resultando de um deslizamento sobre o plano basal na direção <a> sob um regime de deformação coaxial associado a uma trama ou a uma deformação não-coaxial tardia (Fueten et al., 1991). Esta orientação preferencial foi também interpretada como devido ao "annealing" e portanto sem verdadeira relação com os sistemas de deslizamento ativados durante a deformação (Vauchez e Bufalo, 1988).

A evolução das OPR do quartzo nas zonas de cisalhamento foi estudada por numerosos autores (p. ex., Schmid e Casey, 1986; Vauchez, 1987; Lloyd et al., 1992). As variações das OPR dos eixos-c e dos eixos-a para o quartzo em função do gradiente metamórfico são esquematizadas na Fig. 4.7c. Essas variações são correlacionadas com a evolução da atividade dos principais sistemas de deslizamento no quartzo. Além disso, as OPR do quartzo medidas nas zonas de cisalhamento naturais são geralmente assimétricas. As relações de assimetria entre as OPR dos eixos-c e dos eixos-a e a trama tectônica (foliação e lineação) foram preditas por estudos teóricos (Bouchez et al,, 1983; Etchecopar et Vasseur, 
1987). As assimetrias dos padrões do quartzo são em geral bons indicadores do sentido do cisalhamento (p. ex., Bouchez et al., 1983).

\subsubsection{Microestruturas : observações}

O quartzo está presente em todas as amostras e constitui, juntamento com o plagioclásio, as principais fases cristalográficas. Ele se apresenta geralmente sob a forma de longas bandas ("ribbon") policristalinas alongadas paralelamente à foliação (Fig. 4.8). Somente as amostras RB559 e RB689 não apresentaram quartzo em "ribbon". Nestas duas amostras, o quartzo constitui respectivamente, $15 \%$ e $20 \%$ do conteúdo modal, os grãos possuem um tamanho variável com contornos irregulares e os limites de grão estão relativamente curvos. Os grãos de quartzo do enderbito RB559 são muitas vezes poiquilíticos; alguns grãos de tamanho milimétrico contêm inclusões de grãos opacos de forma arredondada (essencialmente óxidos de Fe-Ti).

Geralmente os "ribbons" de quartzo apresentam uma grande regularidade e alternamse com camadas constituídas de grãos de feldspato recristalizados (Fig. 4.8a) e/ou camadas compostas principalmente de biotita e piroxênios (Fig. 4.8c). O limite dos "ribbons" no contato dos porfiroclastos de plagioclásio é menos reto que aquele que bordeja as camadas ricas em biotita. Certos "ribbons" apresentam cristais muito alongados. Para os "ribbons" de largura inferior a $1 \mathrm{~mm}$, os grãos que o constituem apresentam uma forma retangular. Para os "ribbons" maiores (até 2-3 mm, Fig. 4.8d), os limites grão da matriz - grão de quartzo são retilíneos e os limites inter- grãos são curvilíneos. A maioria dos cristais de quartzo não possui sub-estrutura (paredes de discordância, lamela de deformação...); eles apresentam, algumas vezes, uma fraca extinção ondulante (por exemplo RB566) e, mais excepcionalmente, paredes de discordância bem espaçadas fazendo um ângulo de $50^{\circ} \mathrm{em}$ relação ao alongamento do "ribbon". Certas bandas são caracterizadas por um grande número de inclusões de biotita e de plagioclásio de forma sigmóide nos cristais de quartzo (Fig. $4.8 \mathrm{~b}, \mathrm{e})$. 
(a)

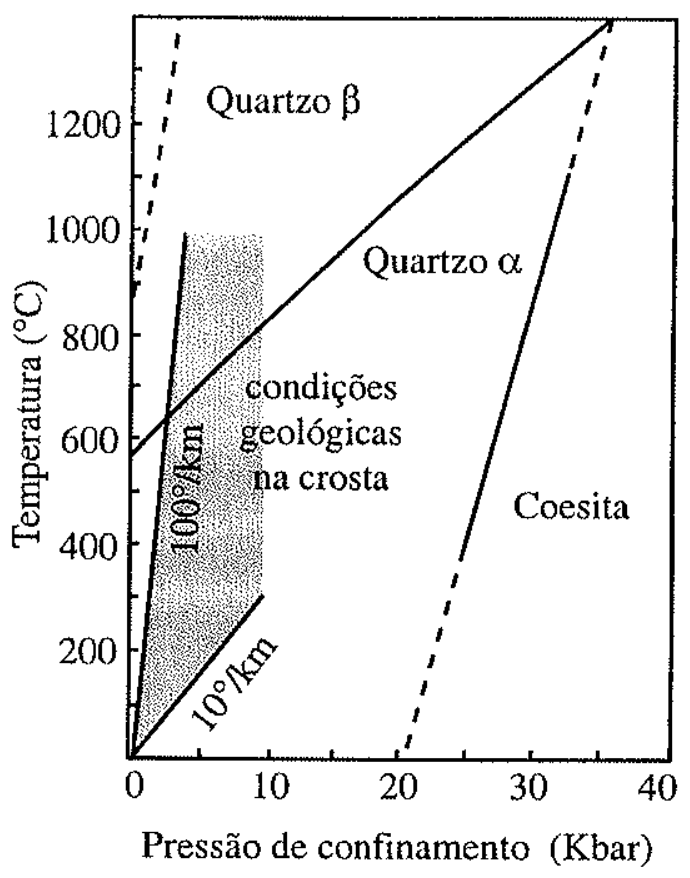

(b)
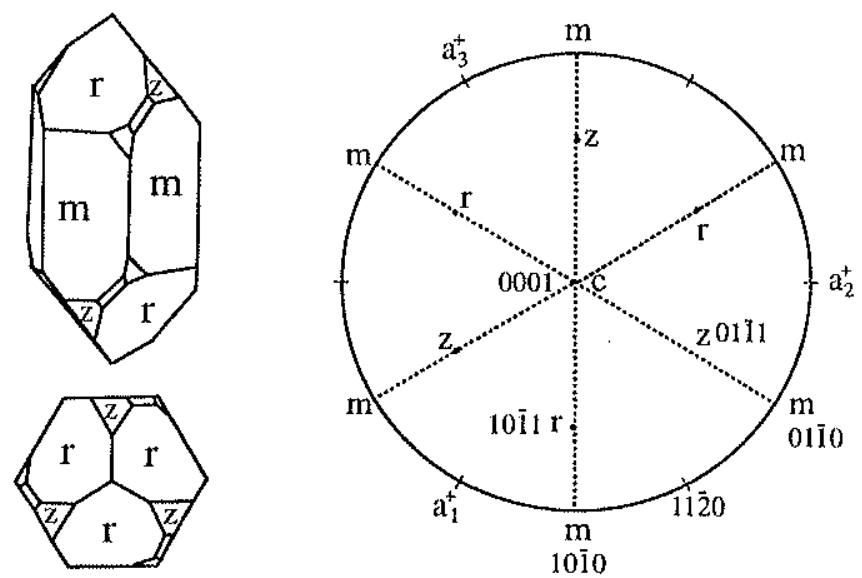

(c)

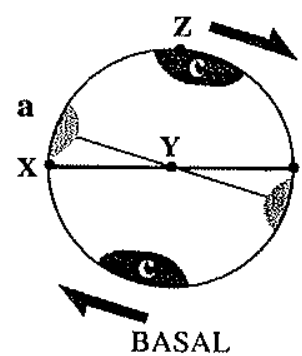

Temperatura Baixa a

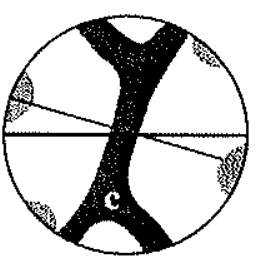

BASAL

$+$ ROMBOIDAL $+$ PRISMÁTICO a

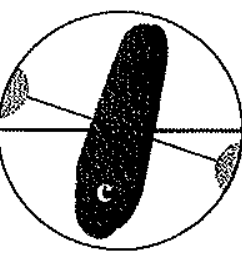

PRISMÁTICO $<a>$ $+$ ROMBOIDAL a

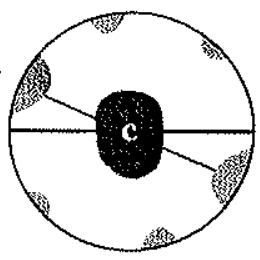

PRISMÁTICO

$<\mathrm{a}>$

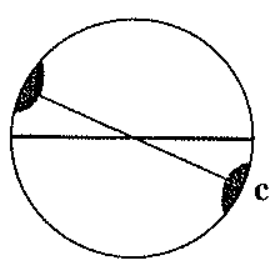

PRISMÁTICO

[c]

Temperatura Média

Temperatura Alta

Fig. 4.7. Estrutura e orientação preferencial do quartzo. (a) Diagrama $(P, T)$ de transformação de fase do quartzo; (b) Cristalografia do quartzo- $\alpha$; (c) Localização das concentrações máximas dos eixos c e a no decorrer de uma deformação por cisalhamento e o sistema de deslizamento dominante (modificado de Passchier e Trouw, 1996). 

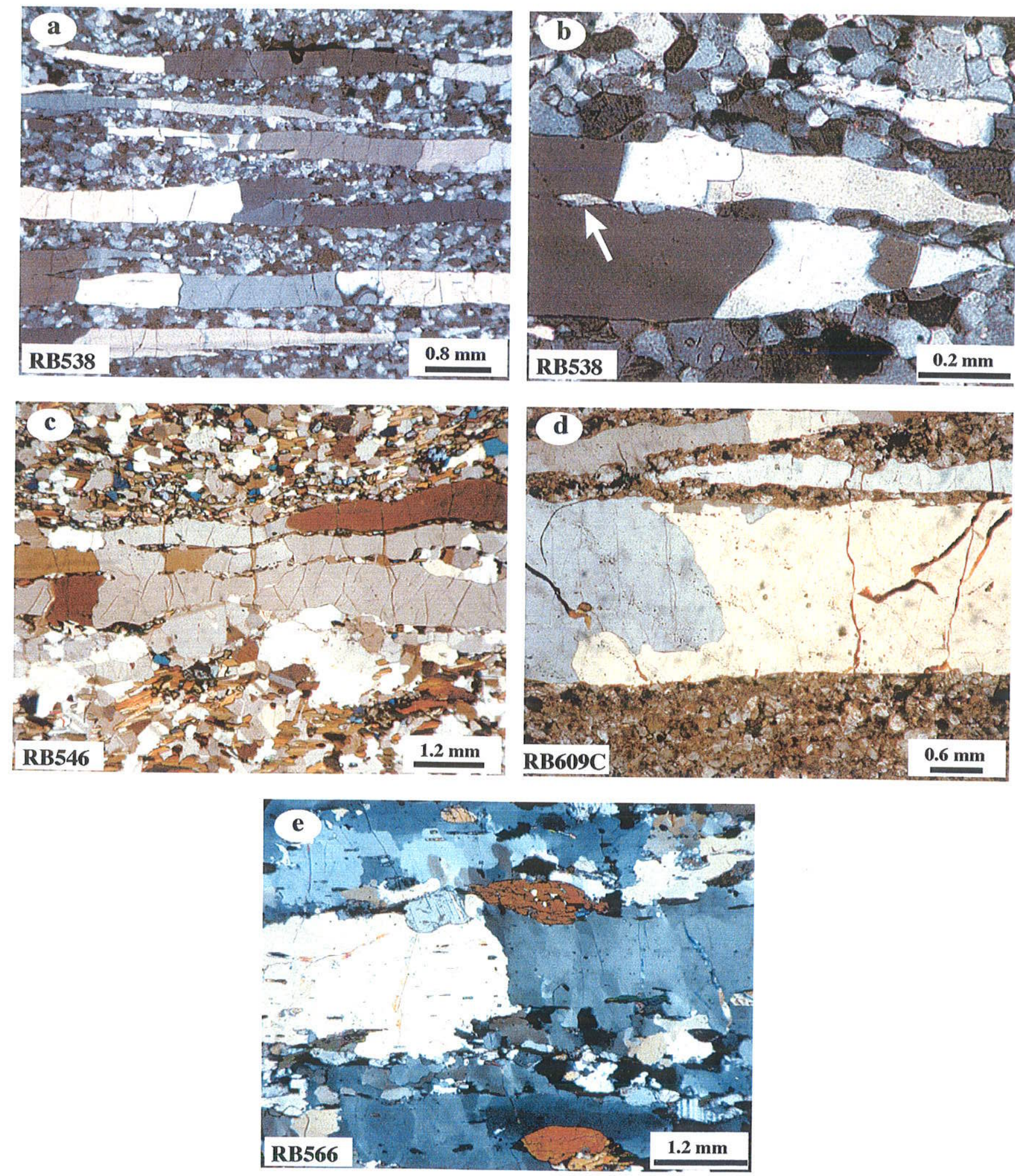

Fig. 4.8. "Ribbons" policristalinos de quartzo nos milonitos. (a) Alternância de "ribbons" de quartzo com bandas de grãos de feldspatos recristalizados; $\mathrm{Em}$ (b) a flecha indica uma inclusão de plagioclásio de forma sigmoidal; (c) "Ribbon" de quartzo em granulito com biotita; (d) "Mega-ribbon" de quartzo com feldspatos recristalizados a sua volta; (e) Extinções ondulantes fracas em um metassedimento rico em quartzo. Não se observa traços da deformação plástica (sub-estruturas) nos "ribbons" de quartzo das outras amostras. Nicóis parcialmente cruzados. 


\subsubsection{As OPR medidas}

As figuras de pólo diretas e inversas do quartzo estão apresentadas na Fig. 4.9. Os máximos de concentração não são muito fortes. O eixo-c é o eixo cristalográfico que apresenta as mạis fortes concentrações. Três grandes tipos de padrões do eixo-c distinguem-se em relação aos eixos da deformação finita $X, Y, Z$ :

- o primeiro tipo é o mais freqüente (RB548, RB609C, RB538, RB540 e RB607A). Ele é caracterizado por uma concentração dos eixos-c entre os eixos $\mathrm{X}$ e Z, geralmente acerca de $40^{\circ}$ do eixo $Z$. A repartição dos eixos c não apresenta simetria em relação ao plano (XY). Os pólos dos planos prismáticos a e m associados com certos padrões do eixo-c são caracterizados por máximos de concentração acerca de $25^{\circ}$ da lineação. Finalmente, essas OPR do quartzo revelam um padrão dos pólos dos planos do romboedro superior (r) muito característico : a repartição é bi-modal, com um máximo de concentração sub-perpendicular à foliação e o segundo máximo, menos marcado, sub-paralelo à lineação. As relações entre as orientações dos pólos dos planos (r) e os eixos da deformação finita são simples e apresentam uma ligeira obliquidade. As figuras de pólo inversas mostram a importância do plano (r) e as relações dele com a foliação e lineação. A lineação $(X)$ e o pólo da foliação $(Z)$ concentram-se preferencialmente perto de $\mathrm{r}$. A diferença das orientações dos pólos dos planos (r), os planos do romboedro inferior ( $\mathrm{z}$ ) não mostram relações simples em relação aos eixos $\mathrm{X}$, $\mathrm{Y}$ e Z. As amostras RB609C e RB607A, caracterizadas por "ribbons" de quartzo muito longos e largos, apresentam os mais fortes máximos de densidade dos planos prismáticos, romboidrais e do eixo-c. Dentro deste grupo, nota-se pequenas variações : por exemplo, a amostra RB548 mostra uma distribuição relativamente simétrica dos eixos c em relação aos eixos estruturais. Os eixos-c da amostra RB607A são fortemente concentrados sobre (XZ) enquanto que os eixos-c da RB609C tem tendência a formar uma guirlanda em direção ao eixo Y. Os eixos-c da RB540 apresentam dois sub-máximos localizados a $45^{\circ}$ dos eixos $\mathrm{Y}$ e Z, e a dissimetria é inversa àquela das amostras RB609C e RB607A. A amostra RB538 apresenta um submáximo paralelo à $Y$. O padrão do eixo-c desta amostra poderia ser intermediário entre o tipo 1 e 2 ,

- o segundo tipo é caracterizado por uma distribuição preferencial dos eixos-c em volta do eixo-Y. Os eixos-c das amostras RB546 e RB5E definem muitas concentrações agrupadas em volta do eixo- $Y$, com uma concentração máxima entre os eixos Y e Z. A amostra RB5E mostra concentrações secundárias, com os eixos-c a cerca de $45^{\circ}$ dos eixos $\mathrm{X}, \mathrm{Y}$ e $\mathrm{Z}$, e entre os eixos $\mathrm{X}$ e $\mathrm{Z}$. Os pólos dos planos prismáticos a e $\mathrm{m}$ se concentram sobre o plano (XZ), a 
proximidade da lineação. Os pólos dos planos (r) da amostra RB5E mostram relações simples em relação aos eixos estruturais, com um máximo de concentração sub-perpendicular à foliação e um segundo máximo menos marcado sub-paralelo à lineação. O quartzo da amostra RB614 poderia também ser associado com este segundo grupo. De fato, para esta amostra, a lineação não está visível e somente o eixo-Z pode ser determinado com exatidão. A Fig. 4.9. mostra uma concentração dos eixos-c na foliação. Emitindo a hipótese que o máximo de concentração dos eixos [001] do anfibólio (Fig. 4.17) corresponde a uma lineação mineral, então o máximo de concentração dos pólos dos planos $m$ do quartzo se torna sub-paralelo à lineação $(\mathrm{X})$ e o máximo de concentração dos eixos-c do quartzo se torna sub-paralelo à $\mathrm{Y}$,

- o terceiro tipo (RB559, RB607B e RB566) apresenta relações complexas entre a repartição dos eixos-c e os eixos $\mathrm{X}, \mathrm{Y}$ e $\mathrm{Z}$. Os eixos-c definem várias concentrações secundárias e uma principal entre os eixos Y e Z. As concentrações dos pólos dos planos do romboedro (r) e (z) não mostram relações simples com os eixos estruturais, exceto para a concentração máxima dos pólos dos planos (r) da amostra RB566, que está sub-paralela ao eixo $Y$.

\subsubsection{Microestruturas e OPR do quartzo : discussão}

A morfologia dos grãos de quartzo em "ribbons", bem como o grande número de grãos recristalizados de plagioclásio e/ou de biotita da matriz dentro destes "ribbons" indicam uma forte migração dos limites de grão. As observações in situ recentes dos materiais análogos, por exemplo, o octacloropropano (OCP) ou o norcampfor (Park et al., 2001; Ree et al., 1997) e agregados de quartzo natural (Masuda et al., 1997), mostram a importância da migração dos limites de grão durante e depois da deformação que caracteriza o processo de "annealing" (seção 1.2.3). Nas rochas para as quais uma segregação mineral sintectônica conduz a um forte bandamento composicional, a migração dos limites de grão perpendicularmente à foliação é restringida, e o crescimento dos grãos resulta no desenvolvimento de longos "ribbons" de quartzo (p. ex., Boullier e Bouchez, 1978; Hippertt et al., 2001; Egydio-Silva et al., 2002). Além disso, os cristais que formam os "ribbons" não mostram, em geral, traços de deformação plástica, nem tão pouco evidência de recristralização dinâmica posterior ao "annealing" (por exemplo, Fig. 3.16 em Passchier e Trouw, 1996). Porém, as formas em "platten-quartz" são conhecidas por serem instáveis porque os limites de grão convergem em pontos triplos à $90^{\circ}$ e por causa das inclusões, que 
são heterogeneidades que conduzem a concentrações de esforço durante reinício da deformação. A ausência de sub-estrura e a preservação das forma retangulares sugerem que a formação dos "ribbons" não foi seguida de uma fase de deformação significativa a baixa temperatura.

Um dos problemas fundamentais para a interpretação das fábricas de quartzo em domínio granulítico concerne ao efeito do "annealing" sobre as OPR desenvolvidas durante a deformação. Este problema é particularmente presente na zona estudada pois, as amostras que mostram os "ribbons" de quartzo de maior comprimento e largura, estão caracterizadas para uma OPR do quartzo do tipo 1 , com os eixos-c entre X e Z. A concentração pode ser localizada a cerca de $40^{\circ}$ do eixo Z (RB607A) ou então em forma de guirlanda na direção do eixo Y (RB609C), e a concentração dos eixos a está perto da lineação. Uma interpretação destas OPR, não considerando a microestrutura do quartzo observada, sugere uma ativação dominante do sistema basal $\{c\}<a>$, que é o sistema dominante à baixa temperatura. $O$ efeito do "annealing" sobre as OPR do quartzo é ainda mal conhecido. As experiências realizadas sobre agregados de quartzo natural para os quais uma temperatura alta é mantida após anulação do esforço diferencial mostram resultados contrastantes: os experimentos de Green (1967) indicam uma concentração preferencial do eixo-c do quartzo paralelamente a direção de compressão; os experimentos de Gleason e Tullis (1990) em alta temperatura e baixa velocidade de deformação, sugerem que o "annealing" favorece uma nova OPR, enquanto que, nos experimentos recentes de Heilbronner e Tullis (2001), a OPR de quartzo preexistente não é significativamente modificada. Estes últimos resultados estão de acordo com os experimentos de "annealing" realizados por Park et al. (2001) com o octacloropropano e o norcampfor.

Uma das características das OPR do quartzo medidas nas nossas amostras é a orientação preferencial dos pólos dos planos (r) que apresentam relações simples com os eixos de deformação finita : a repartição é bi-modal, com um máximo de concentração subperpendicular à foliação, e um segundo máximo, estatisticamente menos significativo que o primeiro, sub-paralelo à lineação (OPR do quartzo do tipo 1). A concentração dos pólos dos planos (r) está relacionada diretamente à largura dos "ribbons". Estas observações sugerem fortes relações entre a orientação preferencial do plano (r) do quartzo e a formação dos "ribbons". A importância dos planos (r) foi recentemente apontada por Kruhl e Peternell (2002). Estes autores observaram, em rochas deformadas sob diferentes graus de metamorfismo, uma concentração de segmentos retos de limite de grão de quartzo paralelamente aos planos (r) com o aumento da temperatura. Kruhl e Peternell (2002) sugerem ainda que os limites dos grãos se estabilizam nas posições de baixa energia. 


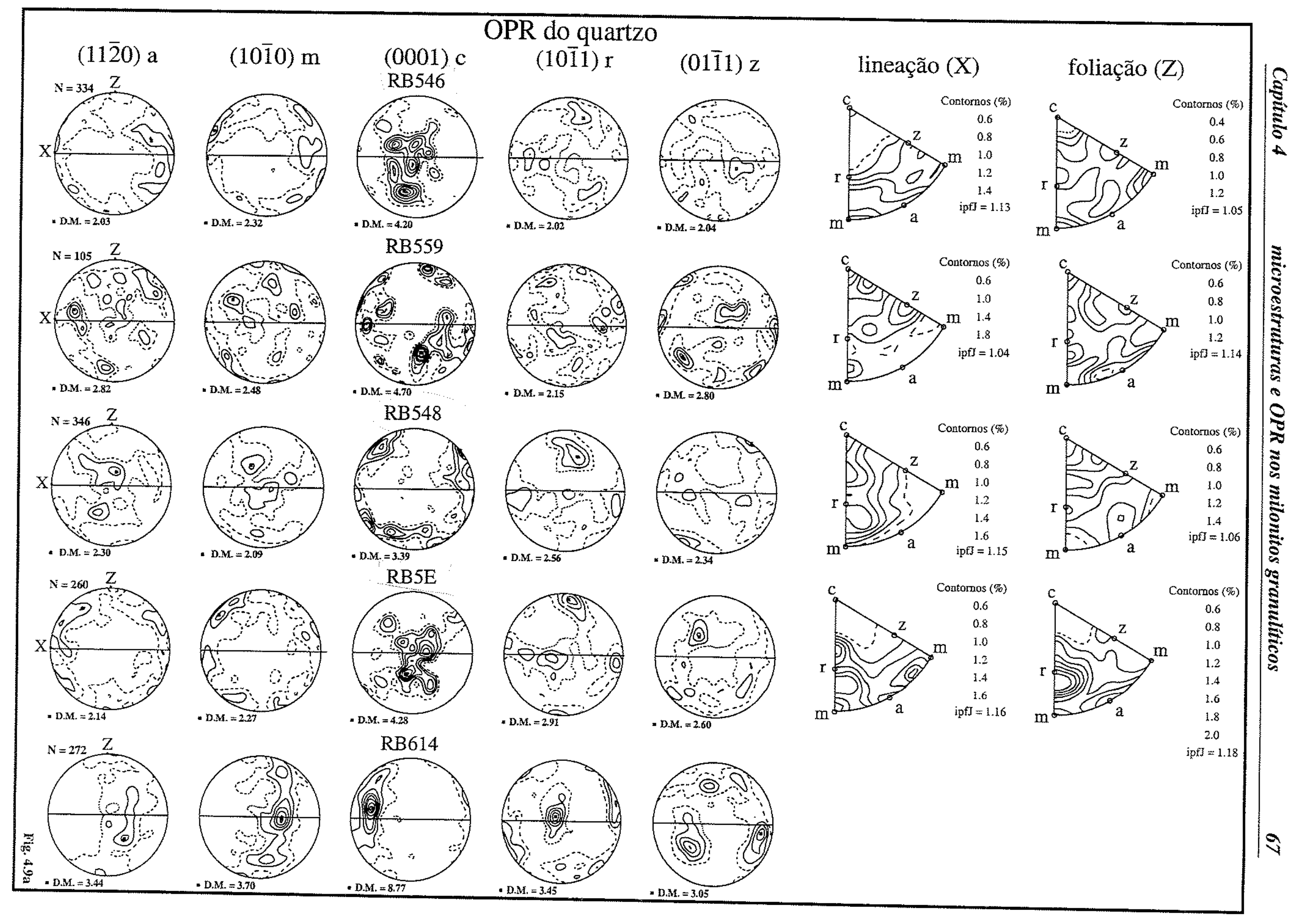




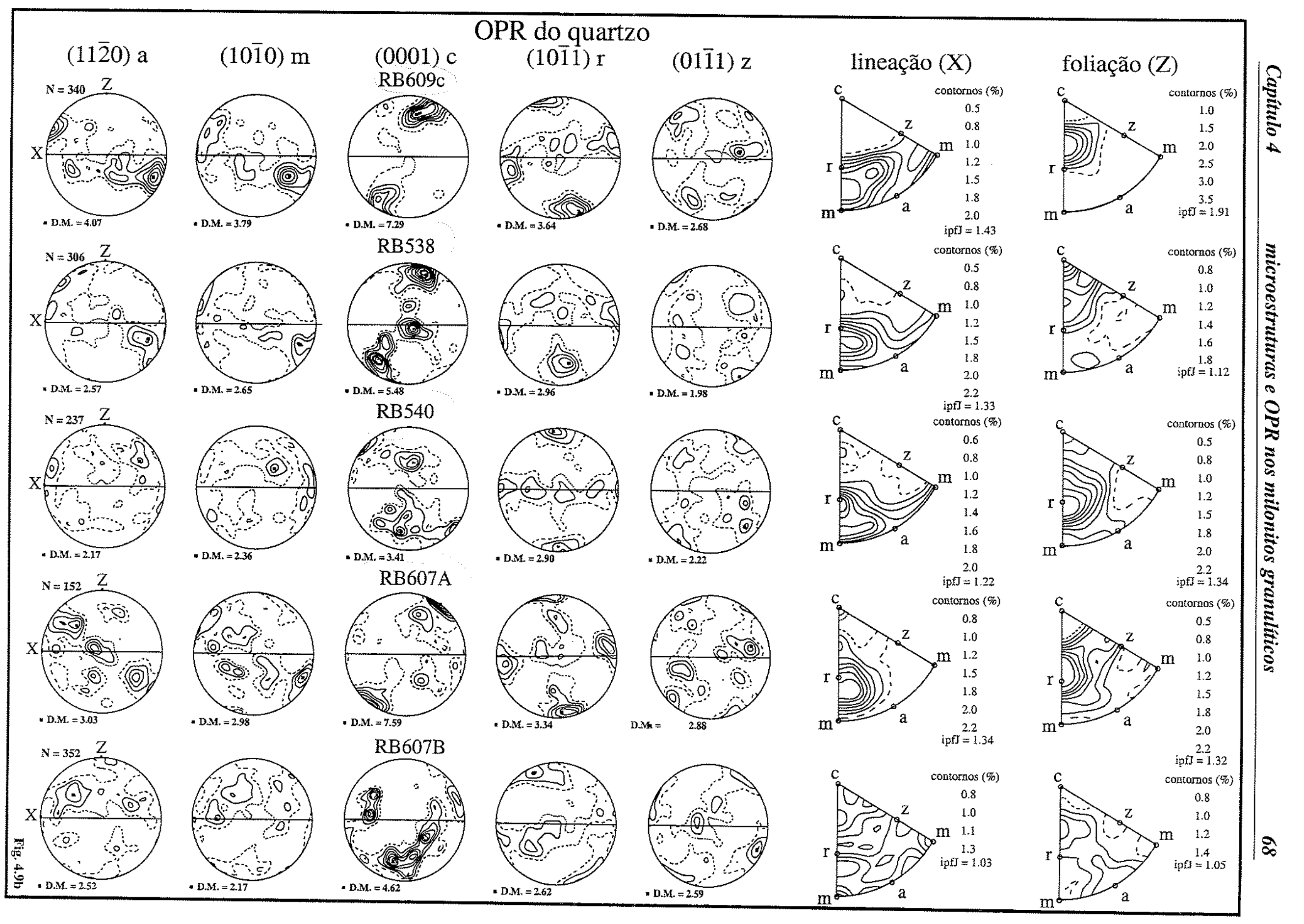




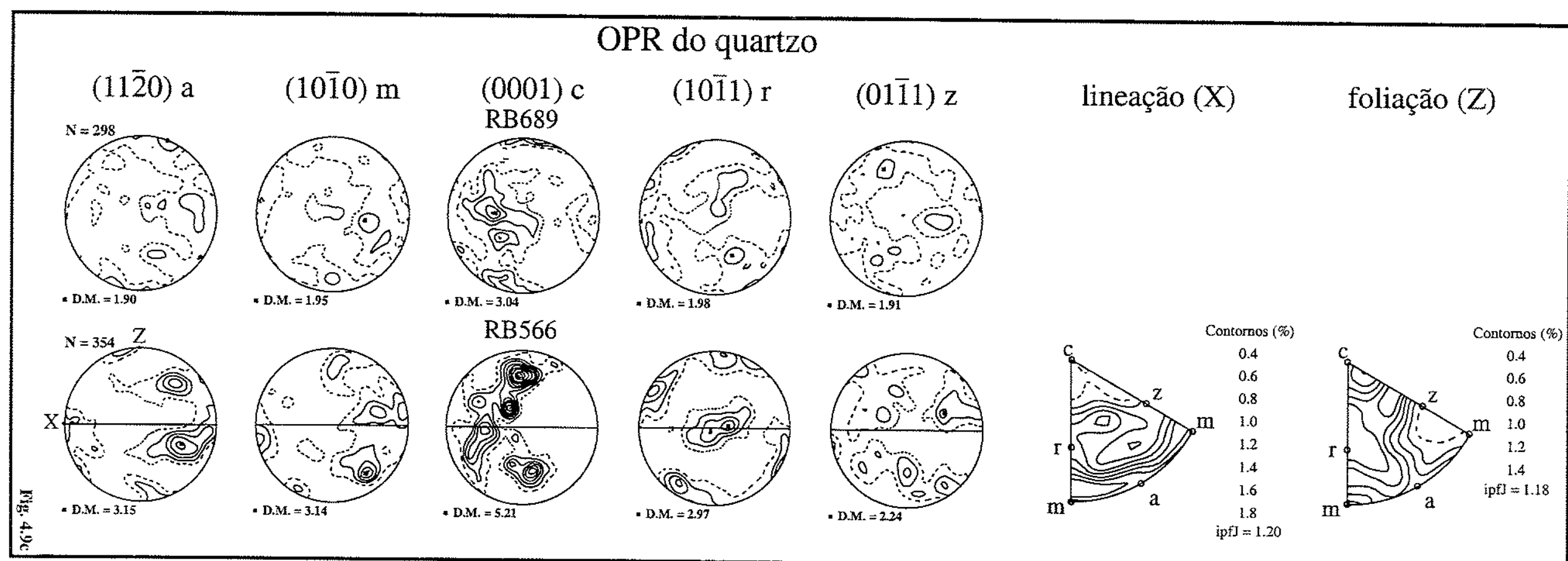

Fig. 4.9. OPR do quartzo apresentado em figuras de pólo diretas e inversas. Projeção sobre o hemisfério inferior em igual área. Contornos $1,1.5,2,2.5 \% \ldots$ para $1 \%$ de área, para as figuras de pólo diretas. A foliação (plano XY; reta plena) é vertical e a líneação $(X)$ é horizontal. N: o número de medidas; D.M. = Densidade máxima. 
A orientação preferencial dos limites de grão paralelamente aos planos (r) poderia então constituir uma das características do "annealing".

A milonitização na região de Santo Antônio de Pádua ocorre em condições de alta temperatura $\left(>750^{\circ} \mathrm{C}\right)$ e pressão relativamente baixa $(<800 \mathrm{MPa})$. Nessas condições de alta temperatura, o deslizamento prismático $\{\mathrm{m}\}$ nas direções $[\mathrm{c}] \mathrm{e}<\mathrm{a}+\mathrm{c}>$ torna-se muito ativo. Em função da proporção de fases hidratadas na rocha, o deslizamento prismático $\{m\}$ nas direções $<a>($ sistema $\{10 \overline{1} 0\}<a>$ ) pode também estar muito ativo. As OPR do quartzo sugerindo a ativação deste sistema, isto é as OPR caraterizadas pelo eixo-c sub-paralelo à Y e o eixo-a perto da lineação, foram medidas na região de Santo Antônio de Pádua (OPR do quartzo de tipo 2). A observação de uma OPR intermediária entre os tipos 1 e 2 (amostra RB538) poderia indicar a evolução de uma OPR sin-cinemática (tipo 2) para uma OPR póscinemática (tipo 1). Esta transição das OPR do tipo 2 à 1 não é ainda bem compreendida, entretanto algumas idéias podem ser estabelecidas, por exemplo: (1) a formação das geminações de Dauphiné durante a deformação e/ou durante uma mudança de fase (quartzo- $\beta$, quartzo- $\alpha$ ). A deformação experimental sobre quartzito realizada por Tullis et al. (1973) mostra que a ativação das geminações de Dauphiné provocam uma concentração dos pólos dos planos (r) paralelo ao eixo de compressão e uma diminuição das orientações preferenciais dos pólos dos planos do romboedro negativo $(z)$. A não-equivalência das figuras de pólo dos planos (r) e (z) do quartzo, (Fig. 4.9) poderia ser um argumento para correlacionar a orientação preferencial dos pólos (r) perto do pólo da foliação com a formação das geminações de Dauphiné em regime de deformação em transpressão (ver p. ex., Mainprice et al., 1993). Entretanto, os resultados preliminares de um estudo estatístico das relações angulares entre as diversas orientações preferenciais ("angular misorientation statistics") não confirmam a hipótese de uma geminação importante do quartzo; (2) a transição entre o quartzo- $\alpha$ e o quartzo- $\beta$ durante a milonitização ou durante o "annealing". De fato, o crescimento exagerado do quartzo poderia refletir uma evolução em um campo de estabilidade do quartzo- $\beta$ (Joesten, 1983; Wirth, 1985). Durante a transformação do quartzo- $\alpha$ em quartzo- $\beta$, a distorção da rede cristalográfica dos limites de grão aumenta por causa das variações na estrutura dos tetraedros $\mathrm{SiO}_{4}$ (Wirth, 1985). Com este aumento do estado de desordem nos limites de grão uma diminuição da energia de ativação é necessária para a migração dos limites de grão. Este decréscimo da energia de ativação favorece a transferência dos átomos da superfície de um grão de alta energia para o limite do grão, e do limite de grão para a superfície de um outro grão de baixa energia que portanto vai crescer. Além disso, este 
aumento do volume dos grãos vai gerar um esforço local sobre os grãos de quartzo em contato com outros minerais; este esforço local vai se tornar um motor adicional para a migração dos limites de grão.

\subsubsection{Os feldspatos}

\subsubsection{Estrutura e deformação plástica}

Em função de sua composição química, os feldspatos são divididos em dois grupos: os feldspatos sodi-potássicos ou alcalinos (ortoclásios) e os feldspatos calco-sódicos (plagioclásios). Os feldspatos sodi-potássicos possuem uma simetria monoclínica, no caso da série do ortósio $\left[\mathrm{AlSi}_{3} \mathrm{O}_{8}\right] \mathrm{K}$ ou triclínica, pseudo-monoclínica no caso da série da microclina $\left[\mathrm{AlSi}_{3} \mathrm{O}_{8}\right](\mathrm{K}, \mathrm{Na})$. Os plagioclásios formam uma série contínua do pólo sódico $\left[\mathrm{AlSi}_{3} \mathrm{O}_{8}\right] \mathrm{Na}$ (albita) até o pólo cálcico $\left[\mathrm{AlSi}_{3} \mathrm{O}_{8}\right] \mathrm{Ca}$ (anortita). Eles cristalizam no sistema triclínico. Os feldspatos são tectossilicatos cuja estrutura é constituída por uma estrutura tridimensional de tetraedros $\mathrm{TO}_{4}$ (onde $\mathrm{T}$ é um átomo de $\mathrm{Si}$ ou $\mathrm{Al}$ ) que comporta grandes cavidades nas quais se alojam os cátions M (Na ou Ca para os plagioclásios, Fig. 4.10).

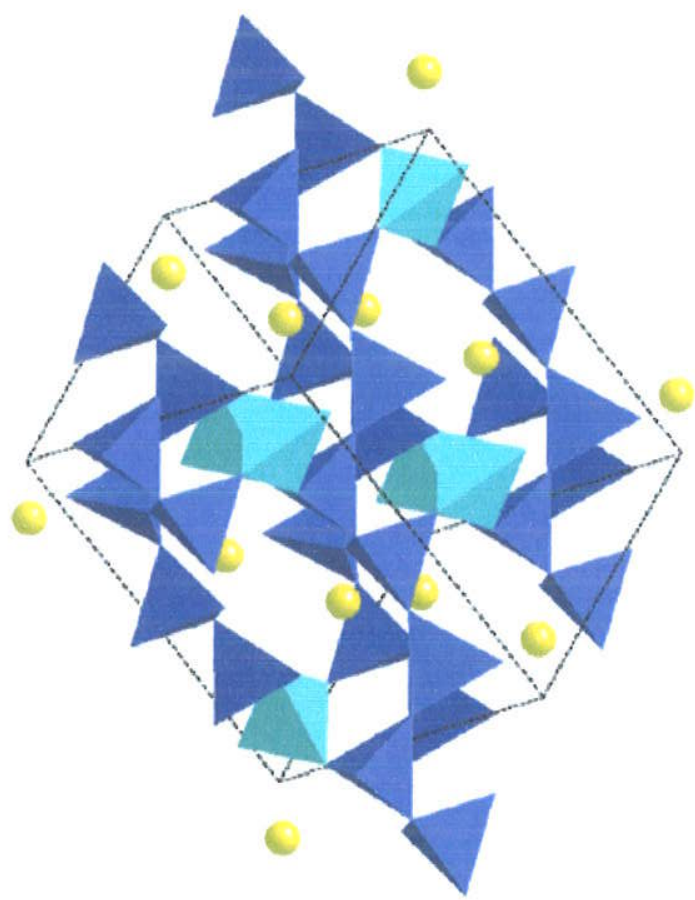

Fig. 4.10. Estrutura cristalográfica da albita ("low albite", C2/m). Vista paralela ao plano $(2,1,2)$. As esferas amarelas são os átomos de $\mathrm{Na}$. Para os tetraedros $\mathrm{TO}_{4}$ de cor verde $\mathrm{T}=\mathrm{Al}$, e para os tetraedros de cor azul $\mathbf{T}=\mathrm{Si}$. As linhas pontilhadas simbolizam a malha elementar. 
A maioria dos trabalhos experimentais e das análises de microscopia eletrônica sobre os feldspatos naturalmente deformados foram realizados em plagioclásios. As propriedades plásticas dos feldspatos alcalinos são ainda mal conhecidas. Entretanto, como o comportamento plástico dos tectossilicatos está ligado à capacidade de ruptura das ligações TO-T, e como os feldspatos alcalinos e os plagioclásios têm uma rede cristalográfica similar, o seu comportamento plástico deve ser relativamente semelhante (Gandais e Willaime, 1984). A reologia dos plagioclásios depende fundamentalmente do teor em anortita e das condições do metamorfismo. Para uma baixa temperatura homóloga (T/Tm, onde Tm é a temperatura de fusão), o feldspato deforma-se principalmente através do micro-fraturamento (comportamento frágil) e do fluxo cataclástico. A deformação por geminação do plagioclásio sobre os planos de geminação da albita e do periclinio é importante (p. ex., Kronenberg e Shelton, 1980; Egydio-Silva e Mainprice, 1999). Para temperaturas homólogas mais altas, o feldspato se deforma não somente por micro-fraturamento mas também por fluxo de discordâncias. Para uma temperatura ainda mais alta, a recristalização torna-se o principal processo de deformação. Os experimentos de Tullis e Yund (1991) sugerem que a recristalização está dominada pela nucleação e o crescimento de novos grãos. A recristalização dinâmica efetuase principalmente por migração de limites de grão, e, secundariamente, por rotação de subgrãos (Ji et Mainprice, 1990; Egydio-Silva et al., 2002). Os estudos de microscopia eletrônica em plagioclásios deformados sob condições de temperatura e de pressão diferentes (Montardi e Mainprice, 1987; Ji e Mainprice, 1988 ) mostram que o sistema de deslizamento dominante é : (010) [001], seguido pelo sistema (010) [100]. A atividade do sistema (010) [100] foi também relatada para o feldspato-K por Gandais e Willaime (1984). Kruhl (1987) mediu as OPR de plagioclásios em gnaisses da fácies anfibolito caracterizadas por (001) sub-paralelo à foliação e [100] sub-paralelo à lineação, sugerindo a ativação do sistema (001) [100]. Este sistema de deslizamento poderia ser ativo em alta temperatura e/ou para teores altos de anortita (Kruhl, 1987). Nos experimentos de temperaturas muito altas $\left(\geq 900^{\circ} \mathrm{C}\right.$ ), o número de sistemas de deslizamento ativos durante a deformação aumenta e sistemas de deslizamento, tais como, (001) 1/2 [110], (001) 1/2 [110] ou ainda (010) [101], poderiam ter uma atividade tão forte quanto o sistema (010) [001] (Gandais e Willaime, 1984).

Embora o plagioclásio seja o mineral mais abundante da crosta terrestre, o número de OPR do plagioclásio publicadas é muito inferior as do quartzo. Isto é devido, principalmente à dificuldade em medir as OPR do plagioclásio através da platina universal, porque para este mineral os indicadores ópticos e os eixos cristalográficos não são paralelos e as relações 
angulares variam com a porcentagem de anortita (Fig. 4.11). Além disto, a medida das OPR do plagioclásio na platina universal demanda muito tempo, e é muito trabalhosa, devida à necessidade de medir os três indicadores ópticos, bem como duas de suas direções cristalográficas (geminação albita, geminação periclina, clivagem (001) ou (010)) é muito trabalhosa (p. ex., Ji et al. 1994). Com a platina universal, os grãos recristalizados de pequeno tamanho e sem geminação não podem ser medidos e as orientações cristalográficas completas dos plagioclásios $\left(<\mathrm{An}_{35}\right)$ são praticamente impossíveis de serem determinadas sem ambigüidade. Ultimamente vários trabalhos foram publicados apresentando as OPR medidas por difração de elétrons retroespalhados em milonitos ricos em albita (Prior e Wheeler, 1999), ou de composição próxima da andesina (Lapworth et al., 2002).
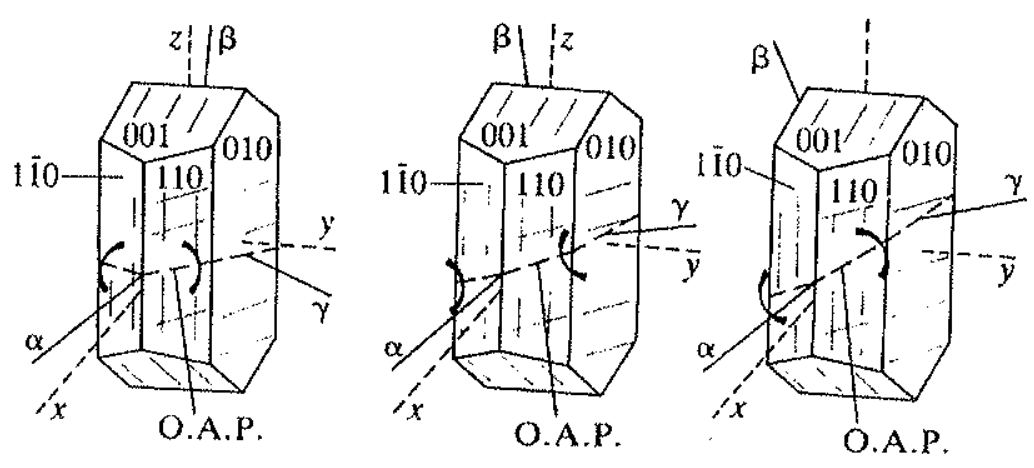

Fig. 4.11. Orientações cristalográficas e ópticas da albita, do oligoclásio e da andesina. Com o aumento da porcentagem de anortita, o ângulo entre os eixos opticos $(\alpha, \beta, \gamma)$ e as direçốes cristalográficas $(x, y, z)$ é maior.

\subsubsection{Microestruturas : observações}

O plagioclásio representa de 20 a $50 \%$ do conteúdo modal das amostras estudadas. $\mathrm{Na}$ maioria dos milonitos, o plagioclásio forma agregados de grãos recristalizados de dimensões relativamente homogêneas (da ordem de $100 \mu \mathrm{m}$, em média). Quando o quartzo forma "ribbons", o plagioclásio representa o essencial da matriz constituindo camadas paralelas aos "ribbons" de quartzo (Fig. 4.12a). Os porfiroclastos de plagioclásios são poucos numerosos (menos de $15 \%$ do plagioclásio), muitas vezes com geminações (albita ou periclinia) e de tamanhos milimétricos. Eles apresentam sub-estruturas que testeimunham uma deformação plástica com extinções ondulantes, paredes de discordância perpendiculares à geminação, "kink-bands" e geminações polissintéticas curvas. Os limites de grão são irregulares e as geminações deformadas têm extremidades pontiagudas. Em algumas amostras, cristais de plagioclásios tem tamanhos de $500 \mu \mathrm{m}$ à $1 \mathrm{~mm}$, contornos curvilíneos, e contêm um grande 
número de inclusões (particularmente de biotita e óxidos) sugerindo uma forte mobilidade dos limites de grão. No charnockito RB559, os grãos de plagioclásio apresentam uma zonação, sugerindo um crescimento magmático, e estão deformados (ver geminação encurvada, Fig. 4.12b).

Os grãos finos recristalizados de plagioclásios não mostram uma deformação interna, embora, ocasionalmente, apresentem uma ligeira extinção ondulante. Eles têm formas poligonais com limites curvi-planares que convergem em pontos triplos à $120^{\circ}$. O processo de recristalização, que origina esta matriz de pequenos grãos poligonais isentos de defeitos cristalográficos, não pode ser determinado quando a recristalização é total. Porém, quando porfiroclastos e grãos recristalizados estão presentes, a formação de sub-grãos na borda dos porfiroclastos bem como a individualização destes sub-grãos em neoblastos sugere um processo de recristalização dinâmica por rotação dos sub-grãos (Fig. 4.12c). Processos de deformação progressiva com recristalização dinâmica e reequilibro por migração dos limites foram propostos para explicar o desenvolvimento das populações de pequenos grãos recristalizados isentos de deformação (Ji e Mainprice, 1990).

A proporção de feldspato-K nas rochas estudadas é variável. Este mineral encontra-se sob a forma de grandes cristais milimétricos alongados paralelamente à foliação. Os limites de grão são sempre curvos e irregulares e os grãos contêm um grande número de inclusões, o que indica um forte crescimento destes minerais. A maioria do feldspato-K apresenta pertitas em forma de gota, de vermes ou em chama (Fig. 4.12e). Estas pertitas estão presentes sobre toda a superfície dos cristais e são geralmente paralelas ao alongamento dos grãos. Intercrescimento mirmequíticos (feldspato contendo quartzo vermicular no seu interior) desenvolvem-se na borda de grãos de feldspato-K (Fig. 4.12f). Os porfiroclastos maiores de feldspato-K apresentam sempre uma extinção ondulante. Na periferia dos porfiroclastos, formam-se grãos recristalizados de feldspato-K e de plagioclásio que chegam a medir uma centena de microns de largura. A matriz da amostra granítica RB609C é quase exclusivamente composta de grãos recristalizados de feldspato-K, e de plagioclásio em menor proporção. Os cristais de feldspato-K têm limites lobados e se interpenetram (Fig. 4.12d), o que indica uma migração dos limites dos grãos. Nota-se também uma individualização na borda dos grãos de pequenos cristais arredondados (alguns microns) sugerindo um processo de nucleação. 

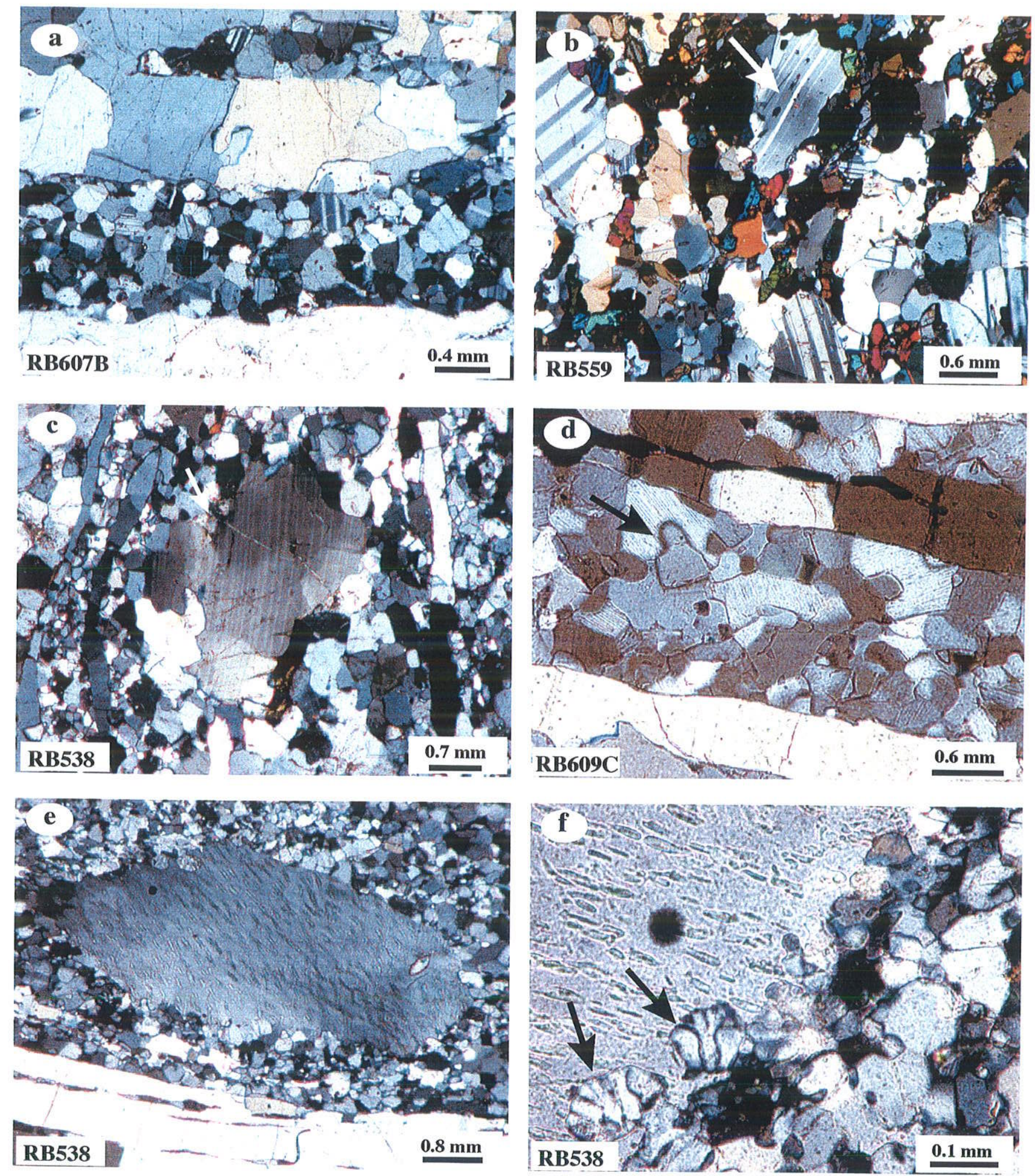

Fig. 4.12. Microestruturas do feldspato. (a) Grãos de plagioclásios recristalizados entre dois "ribbons" de quartzo; (b) Zonação magmática e geminação deformada de forma sinuosa (flecha). A amostra contem igualmente geminações deformadas com terminações pontiagudas; (c) Recristalização por rotação de sub-grãos em um porfiroclasto de plagioclásio. Os neoblastos (flecha) apresentam uma orientação da rede próxima daquela dos subgrãos adjacentes; (d) Pequenos cristais de feldspatos com limites de grãos lobados que se interpenetram; (e) Porfiroclasto de feldspato-K envolto por pequenos grãos recristalizados. $O$ porfiroclasto possui extinção ondulante. Os "ribbons" de quartzo mostram várias inclusões de feldspato de forma sigmoidal; (f) detalhe de (e) mirmequita na borda do porfiroclasto de feldspato potássico. 


\subsubsection{As OPR medidas}

Para a solução sólida dos plagioclásios, a passagem de uma estrutura $\mathrm{Al}_{2} \mathrm{Si}_{2}$ ( pólo puro da anortita) para uma estrutura $\mathrm{AlSi}_{3}$ (pólo puro da albita), implica em uma reconstrução completa da rede cristalográfica. A necessidade de acoplar a substituição de Ca por $\mathrm{Na}$ e $\mathrm{Al}$ por $\mathrm{Si}$, mais as diferentes distorções da rede tetraédrica em função das composições químicas e das temperaturas, tornam complexa a estrutura do plagioclásio. Estas variações de estrutura cristalográfica se traduzem por variações de figuras de difração dos elétrons retroespalhados (e dos raios-X). Uma não homogeneidade química devida a micro-exsoluções, como por exemplo lâminas de ortoclásio nos cristais de plagioclásio (antipertita) são susceptíveis de perturbar o sinal de difração. Estas exsoluções se desenvolvem, principalmente, no oligoclásio e na andesina, são menos frequentes na albita, e raras na labradorita e nos plagioclásios mais cálcicos (Deer e al., 1966).

Para obter uma melhor indexação das imagens de difração dos plagioclásios, foi necessário recalcular a esfera de difração para diferentes porcentagens de anortita e analisar os plagioclásios por sonda iônica a fim de determinar a proporção de anortita neles contida (apêndice II).

Para cada amostra, as figuras de pólo das OPR do plagioclásio (Fig. 4.13) são representativas do conjunto dos grãos de plagioclásio. Devido a simetria triclínica, os eixos opostos ([100] e [100] por exemplo) não são equivalentes. Para uma melhor leitura das OPR, as orientações preferenciais dos pólos dos planos (010) e (001), que são dois planos de deslizamento susceptíveis de ser fortemente ativados em alta temperatura (Gandais e Willaime, 1984), são representadas na figura 4.13a. Nesta figura, também são mostrados orientações dos eixos [100], que é descritas como uma direção preferencial de deslizamento (Ji e Mainprice, 1990). Finalmente, para ilustrar de modo completo as relações entre a lineação e as OPR, e entre a foliação e as OPR, as figuras de pólo inversas foram calculadas. A projeção da lineação e a projeção do pólo da foliação em um referencial cristalográfico da amostra RB538 são apresentadas na figura 4.14.

As OPR do plagioclásio são caracterizadas por um máximo dos pólos dos planos (010) perto de Z (Fig. 4.13a). Algumas amostras (RB546 e RB538) mostram também um máximo de densidade dos pólos (001) perto de Z. Finalmente, a amostra RB546 mostra um terceiro máximo de densidade dos pólos (120) perto do pólo da foliação (Fig. 4.13b). As figuras de 
pólo (Fig. 4.13b) mostram que o máximo de concentração dos pólos dos planos (101) para a amostra RB607A e dos pólos dos planos (121) para a amostra RB607B é perto de Z.

A figura de pólo inversa projetada para o pólo da foliação mostra que a amostra RB548 é caracterizada por um máximo de concentração do pólo da foliação sub-paralela ao

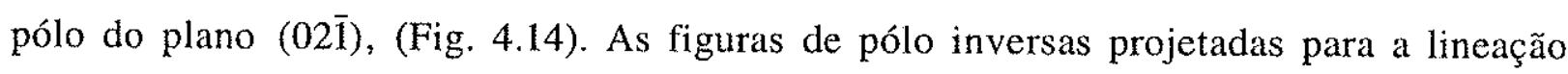
mostram concentrações múltiplas. A lineação concentra-se preferencialmente em volta do eixo [100] para as amostras RB559, RB609A, RB538, RB607A e RB607B. Em alguns casos (RB559 e RB607B), a lineação é também concentrada na proximidade do eixo [001]. Nota-se também (RB538, RB548 e RB607B) uma concentração preferencial da lineação próxima ao eixo [1̄01]].

A força das fábricas de pólo inversa (ipfJ) é mais fraca para a lineação do que para a foliação. Por exemplo, para a amostra RB548, o valor de ipfJ é igual a 1.30 para a lineação enquanto que o valor de ipfJ é igual a 1.61 para a foliação.

Para o feldspato-K, um grande número de medidas de orientação cristalográfica foi obtido somente para a amostra RB609C. A OPR é fraca (Fig. 4.13c) e, exceto para a orientação preferencial do eixo [100], que tende a ser paralelo a lineação, os máximos de densidade não apresentam relações simples com os eixos da deformação finita.

\subsubsection{Microestruturas e OPR dos feldspatos : discussão}

Os feldspatos são caracterizados por uma recristalização dinâmica parcial ou total dos grãos. Geralmente poucos porfiroclastos são conservados. Aqueles que subsistem possuem uma sub-estrutura que evidencia uma deformação plástica significativa (paredes de discordância, sub-grãos e geminações mecânicas). Para o plagioclásio, a recristalização que produz neoblastos bem equilibrados ocorre essencialmente por rotação de sub-grãos. Os feldspatos-K pertíticos mostram uma individualização dos domínios de exsolução no limite de grão. Para o plagioclásio, a rotação dos sub-grãos é o principal mecanismo de recristalização. Alguns grãos recristalizados de plagioclásio e de feldspatos-K sugerem a formação por "bulging" dos limites de grão. O conjunto destes processos de recristalização tem como conseqüiência o desenvolvimento de agregados de grãos finos de feldspato. Os porfiroclastos e os grãos recristalizados de plagioclásio desenvolvem uma OPR característica do mecanismo de fluxo de discordâncias. 


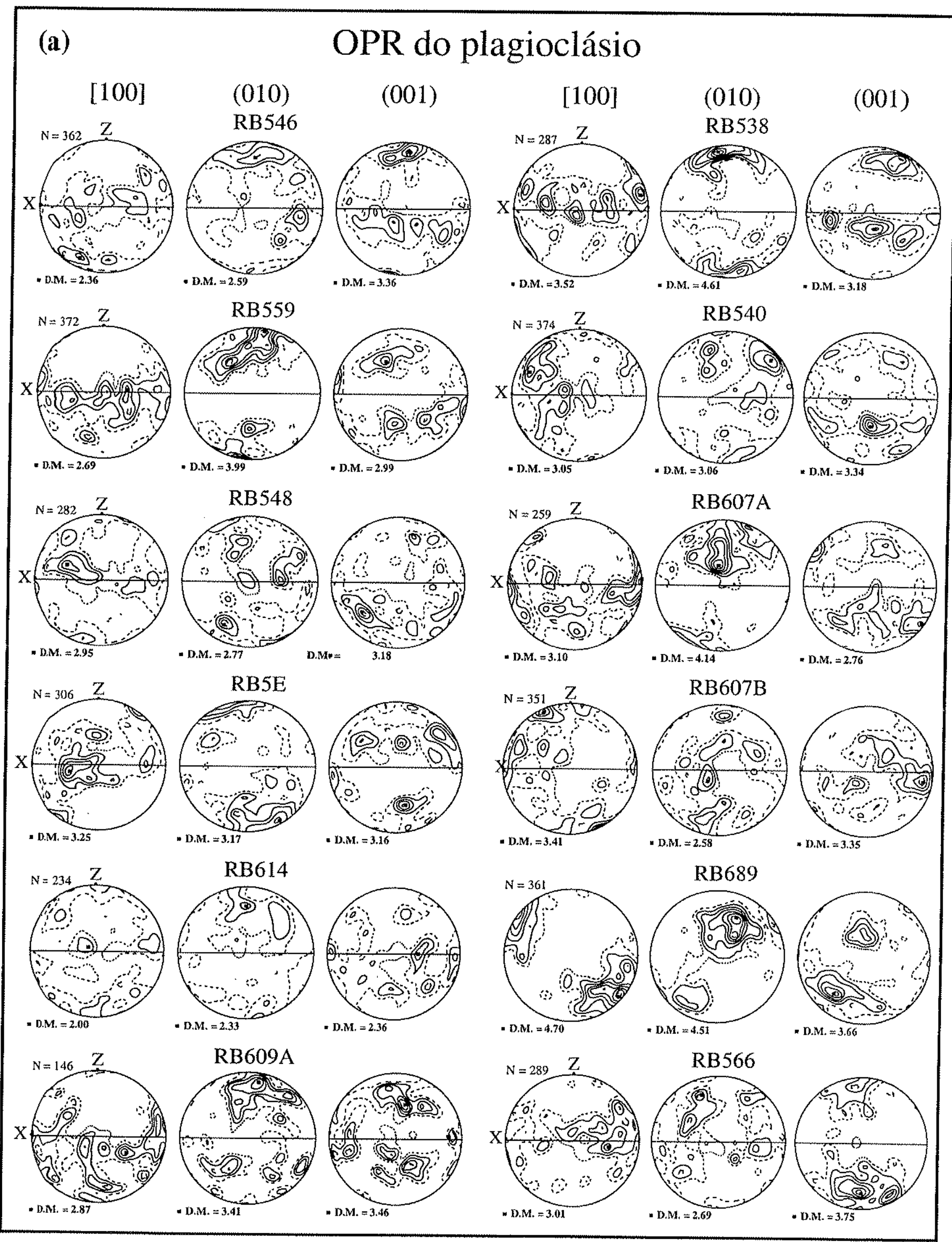

Fig. 4.13. OPR do plagioclásio. Projeção sobre o hemisfério inferior em igual área. Contornos $1,1.5,2,2.5,3,3.5 \% \ldots$. para $1 \%$ de área. A foliação (plano XY; reta plena) é vertical e a lineação (X) é horizontal. N: o número de medidas; D.M. = Densidade máxima. 


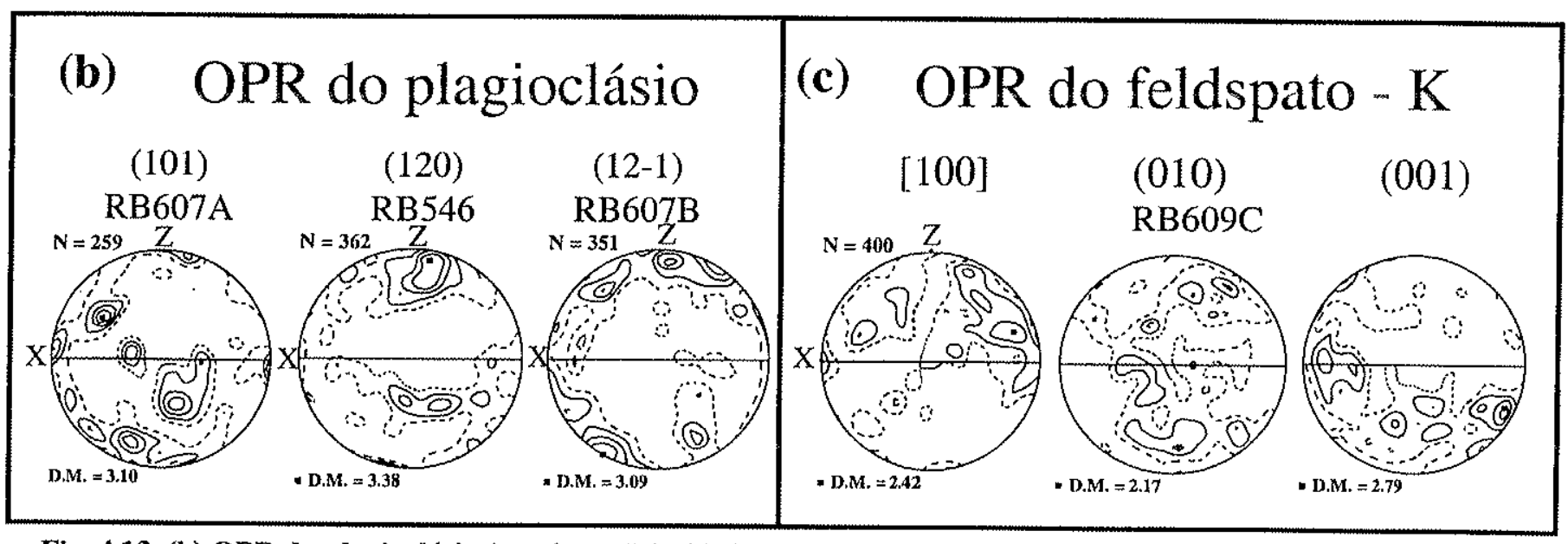

Fig. 4.13. (b) OPR do plagioclásio (continuação); (c) OPR do feldspato - K. Contornos e projeção semelhantes que para (a).

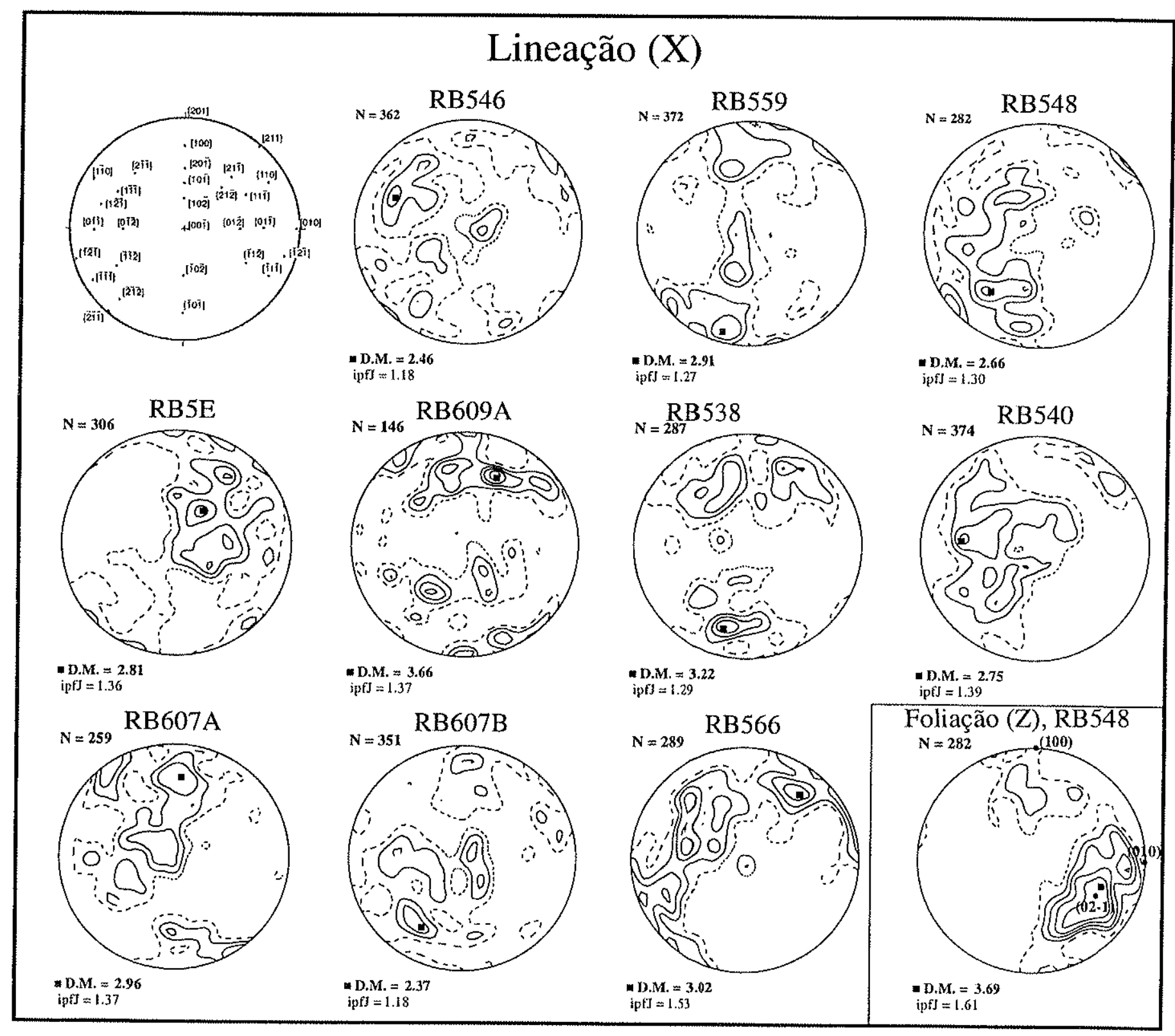

Fig. 4.14. Figuras de pólo inversas da lineação para as amostras estudadas e da lineação para a amostra RB548. Projeção sobre o hemisfério inferior em igual área. Contornos $1,1.5,2,2.5 \% \ldots$ para $1 \%$ de área. ipfJ = força da fábrica. 
A orientação preferencial do pólo do plano (010) perpendicular à foliação sugere que (010) é o plano preferencial de deslizamento das discordâncias. Um outro plano ativo poderia ser o plano (001). Algumas OPR medidas de plagioclásio sugerem um deslizamento sobre os planos (120) e (12î̀). A ativação destes planos de deslizamento foi descrita por Gandais e Willaime (1984). A direção de deslizamento paralela ao eixo [100] parece ser favorecida mas outras direções de deslizamento, [001] ou [101] particularmente, poderiam ter sido ativadas. As OPR medidas sugerem uma ativação preponderante dos sistemas (010) [100] seguido de (010) [001] e de (001) [100]. Estes resultados contrastam um pouco com os resultados obtidos nos trabalhos de Ji e Mainprice (1990) que caraterizaram também o plano (010) como plano de deslizamento mas, associado com uma direção de deslizamento paralela a [001] favorecida em relação a uma direção [100]. Entretanto, a ativação de um grande número de sistemas de deslizamento, do quais alguns são medidos com pouca frequência nos feldspatos naturalmente deformados, estão de acordo com os resultados de deformação experimental dos feldspatos em condições de alta temperatura (Gandais e Willaime, 1984).

\subsubsection{Os piroxênios, o anfibólio e a biotita}

\subsubsection{Estrutura e deformação plástica}

Os piroxênios são silicatos que cristalizam nos sistemas ortorrômbico e monoclínico. Como a deformação plástica dos clinopiroxênios foi tratada no Capítulo 3 - anexo II, somente os ortopiroxênios serão abordados nesta seção. Os ortopiroxênios formam a série química $\left[\mathrm{SiO}_{3}\right](\mathrm{Mg}, \mathrm{Fe})$ com a enstatita $\left(\left[\mathrm{SiO}_{3}\right] \mathrm{Mg}\right)$ e a ferrosilita $\left(\left[\mathrm{SiO}_{3}\right] \mathrm{Fe}\right)$ como termos extremos, e o hiperstênio e o ferrohiperstênio como termos intermediários. O cristal de ortopiroxênio é formado por cadeias de tetraedros de $\mathrm{SiO}_{4}$ dividindo um íon oxigênio, alinhadas na direção [001]. As cadeias são ordenadas em camadas paralelas a (100) em alternância com as camadas contendo os íons Mg e Fe. Devido a esta estrutura cristalográfica, o deslizamento sobre os planos (100) é muito fácil particularmente na direção [001], pois ele não implica o rompimento das ligações Si-O. Esta direção de deslizamento também é favorável pois ela corresponde ao mais curto vetor de Burgers. A ativação deste sistema é observada nos ortopiroxênios deformados naturalmente (Mercier, 1985) e experimentalmente (Griggs et al., 1960). Os sistemas de deslizamento (100) [010] e (010) [001] são também observados (Nazé 
et al., 1987). Os trabalhos experimentais de Ross e Nielsen (1978) sobre policristais de enstatita mostram que o deslizamento sobre (010) [001] é mais difícil e aparece somente em condições de alta temperatura. Durante as deformações experimentais, a poligonização e a recristalização começam somente acima de $1300^{\circ} \mathrm{C}$ para $\dot{\varepsilon}=10^{-4} \mathrm{seg}^{-1}$. A transformação dos piroxênios ortorrômbicos em piroxênios monoclínicos foi o alvo de numerosas publicações (p. ex., Coe e Kirby (1975) para a enstatita e Altenberger (1992) para o hiperstênio). Estas inversões poderiam evidenciar a presença de lamelas de clinopiroxênio no ortopiroxênio hospeiro. Para estes autores, tais transformações são associadas com deformações significativas sob condições P-T elevadas

Os anfibólios são silicatos caracterizados por tetraedros em cadeias duplas. Como para os piroxênios, a estrutura cristalográfica do anfibólio sugere um fácil deslizamento sobre (100) [001]. Os trabalhos realizados sobre anfibólios naturalmente deformados mostram que estes deformam-se por geminação sobre (101) ou (100) (Biermann, 1981) e por deslizamento sobre (100) [001], em baixa temperatura e/ou para uma velocidade de deformação alta. Um número maior de sistemas de deslizamento pode ser ativado em alta temperatura e /ou a baixa velocidade de deformação: os sistemas (hk0) [001] principalmente mas também $\{110\}$ $1 / 2<\overline{1} 10>$ e (010) [100] (Cumbest et al., 1989; Reynard et al., 1989).

As micas pretas (ou ferromagnesianas) e as micas brancas (ou aluminosas) são filossilicatos caracterizados por uma associação de cadeias duplas que constituem folhas planas. Estes minerais têm uma forma fortemente anisotrópica com um baixo desenvolvimento perpendicular ao plano basal (001). A rede cristalina pode ser considerada como pseudo-hexagonal, com o plano (001) correspondendo a um plano de clivagem perfeito. A estrutura cristalográfica das micas sugere que o plano (001) é um plano de fácil deslizamento. Isto é confirmado pelos dados experimentais que evidenciam dois sistemas de deslizamento principais para a biotita: $(001)<110>$ e $(001)<100>$ (Christoffersen e Kronenberg, 1993). Outros mecanismos como o dobramento ("bending" e "kinking") são comuns nas micas e permitem acomodar a deformação. A biotita, geralmente menos resistente que a muscovita, deforma-se ductilmente para temperaturas superiores à $250^{\circ} \mathrm{C}$ (Stesky et al., 1974). 


\subsubsection{Microestruturas : observações}

Na região de estudo, a maioria das rochas contêm piroxênios, em particular ortopiroxênio. Este último possui uma composição relativamente homogênea que o coloca no grupo hiperstênio - ferrohiperstênio (ver análises no apêndice II). Ao microscópio óptico, é difícil diferenciar os orthopiroxênios dos clinopiroxênios, pois ele pode apresentar uma extinção não reta (até uma dezena de graus) e cores de birrefringência altas para uns ortopiroxênios, indo até o início da segunda ordem. O ortopiroxênio apresenta-se geralmente sob a forma de porfiroclastos de grande tamanho (muitas vezes milimétricos) alongados paralelamente à lineação (Fig. 4.14a). Os limites dos porfiroclastos são muito irregulares e podem formar grandes reentrâncias que colocam em contato o ortopiroxênio com plagioclásio ou quartzo. Tais formas poderiam sugerir uma corrosão do ortopiroxênio. Além disso, estes porfiroclastos são envoltos de grão de tamanho médio (cerca de $500 \mu \mathrm{m}$ ), com contornos irregulares, apresentando micro-fraturas e que parecem ser da mesma geração que os grãos maiores. Alguns porfiroclastos de ortopiroxênio estão envoltos por grãos de pequeno tamanho $(<80 \mu \mathrm{m})$ que poderiam ser gerados por recristalização dinâmica. Finalmente, porfiroclastos de tamanho milimétrico são intensamente deformados e apresentam bandas de dobramento ("kink bands") cujo eixo posiciona-se perto da lineação, e das paredes de discordância subperpendiculares ao eixo das dobras (Fig. $4.15 \mathrm{c}$,d). O clinopiroxênio é presente em quantidade menor que o ortopiroxênio. Os clinopiroxênios de maior tamanho (cerca de $800 \mu \mathrm{m}$ ) não apresentam uma anisotropia de forma nítida, mas alguns destes grãos mostram uma extinção ondulante e paredes de discordância curvas.

O anfibólio é sempre cálcico (hornblenda) e apresenta teores em alumínio relativamente altos $\left(\mathrm{Al}_{2} \mathrm{O}_{3}\right.$ geralmente em torno de $12 \%$, anexo II). É frequiente encontrar nas amostras estudadas uma proporção de anfibólio superior a $7 \%$ e pode excepcionalmente atingir 25\% (RB607A). Geralmente, o anfibólio apresenta-se sob a forma de grandes cristais elípticos com razão de forma de 1:3 (Fig. 4.15e). A orientação preferencial dos grãos define uma lineação mineral. Nenhuma sub-estrutura associada com a deformação aparece através da observação destes cristais de anfibólio. Entretanto, a própria cor deste mineral poderia mascarar as sub-estruturas. Alguns cristais de anfibólio apresentam uma forma poligonal e constituem uma parte da matriz polimineral.

As micas pretas estão presentes na maioria das amostras. Elas pertencem ao grupo da biotita exceto a amostra RB566 para a qual a mica é uma flogopita (ver apêndice II). As 
lamelas planas de biotita marcam a foliação. A biotita encontra-se associada ao anfibólio, ao ortopiroxênio e à granada (Fig. 4.15f).

\subsubsection{As OPR medidas}

O ortopiroxênio mostra sempre uma OPR com fortes concentrações dos eixos cristalográficos (Fig. 4.16). A amostra RB607A apresenta a mais forte fábrica cristalográfica e uma repartição dos eixos característica: [100] tende a se colocar perto do pólo da foliação, [010] perto do eixo Y e [001] perto da lineação. Esta OPR encontra-se também nas outras amostras medidas, exceto para a RB546. Esta amostra mostra uma concentração dos eixos [001] nas proximidades do plano de foliação e a cerca de $20^{\circ}$ da lineação, uma concentração dos eixos [100] também no plano de foliação à $45^{\circ}$ de $\mathrm{Y}$ e [010] perto de Z. Uma concentração subsidiária dos eixos [010] perto de $Z$ é observada em algumas outras amostras (RB559 e RB548). As OPR do clinopiroxênio da amostra RB546 não mostram relações simples com os eixos da deformação finita, exceto para [010] que situa-se perto de $\mathrm{Z}$.

O anfibólio mostra uma OPR típica em todas as amostras : o pólo dos planos (100) é sub-perpendicular à foliação, o pólo dos planos (010) é perto de Y e o eixo [001] sub-paralelo à lineação (Fig. 4.17). O plano basal da biotita é sempre paralelo à foliação (Fig. 4.17).

\subsubsection{Microestruturas e OPR dos ortopiroxênios e do anfibólio: discussäo}

O ortopiroxênio é um excelente marcador das deformações plásticas em alta temperatura. As numerosas sub-estruturas observadas (paredes de discordância e bandas de dobramento) bem como a OPR dominante evidenciam uma deformação plástica de alta temperatura, provavelmente da ordem de $800^{\circ}-900^{\circ} \mathrm{C}$. De fato, trabalhos experimentais acerca da deformação do ortopiroxênio mostram que a deformação por saltos de discordâncias ("dislocation climb") ocorre somente para temperaturas superiores a $1000^{\circ} \mathrm{C}$ (Ross e Nielsen, 1978; Nazé et al., 1987). Os sistemas de deslizamento (100) [010] e (010) [001] associam-se ao sistema de deslizamento dominante (001) [001]. Para temperaturas experimentais inferiores a $1000^{\circ} \mathrm{C}$, a deformação por deslizamento deve estar acompanhada de um outro processo de deformação, como o dobramento ("kinking"). Como a deformação do somente pode ocorrer pela ativação de um número reduzido de sistemas de deslizamento, o "kinking" é necessário para permitir uma deformação homogênea. Uma OPR caracterizada por 

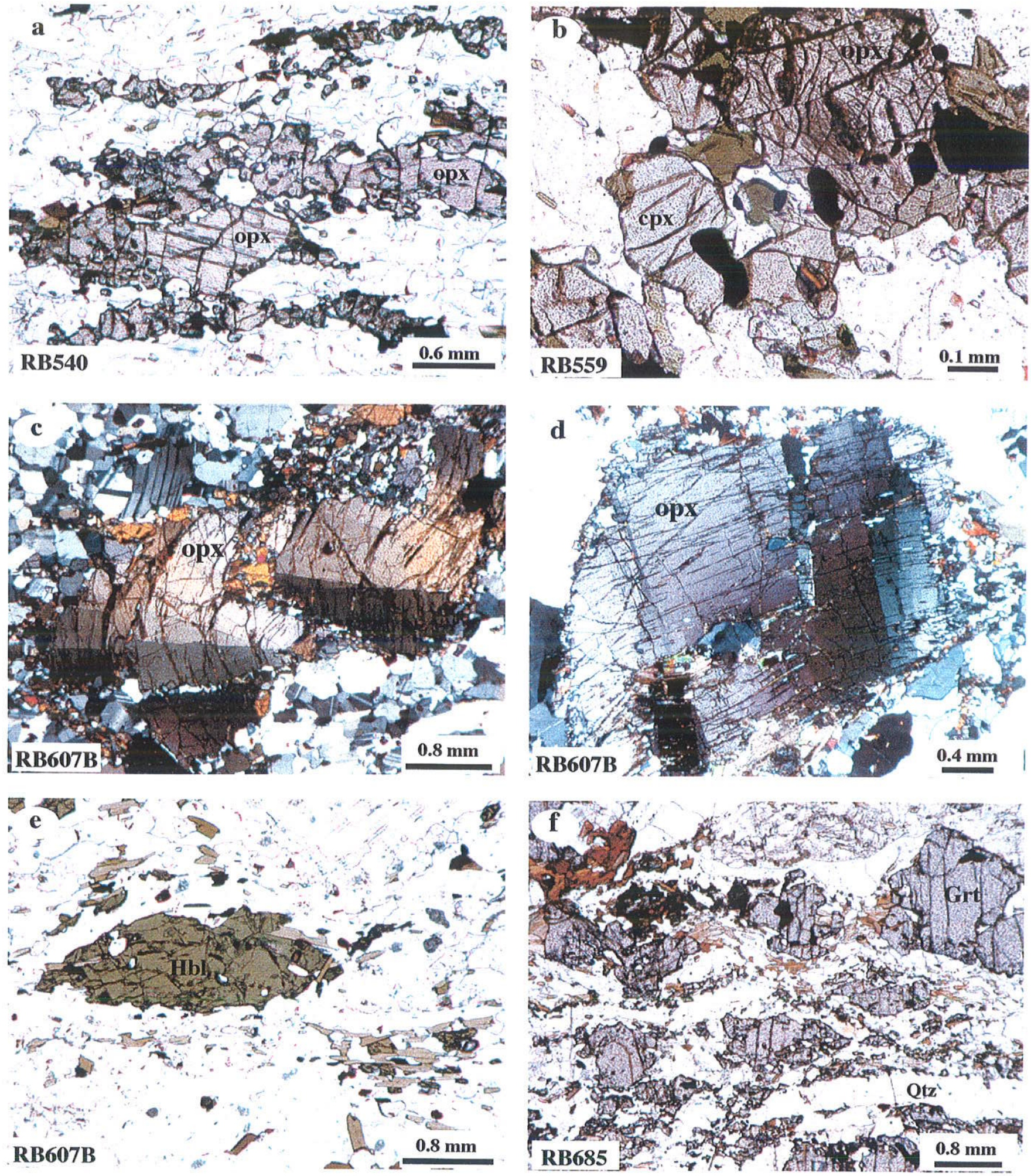

Fig. 4.15. Microestruturas dos piroxênios, dos anfibólios e da granada. (a) Porfiroclastos de ortopiroxênios (hiperstênio); (b) Ortopiroxênio e clinopiroxênio nos gnaisses enderbíticos; (c), (d) "kink-bands" nos ortopiroxênios. O eixo das dobras é sub-paralelo à lineação (a lineação está orientatada E-W em (c) e próximo de $\mathrm{N}-\mathrm{S}$ em (d)); (e) Cristal de anfibólio (hornblenda) de forma elíptica; (f) Granadas sub-automórficas (Grt) nos granulitos com hiperstênio e granadas. A lineação E-W está marcada por longos "ribbons" de quartzo (Qtz). Fotos no plano (XZ); (a), (b), (e), (f) são em luz natural e as fotos (c) e (d) em luz polarizada. 


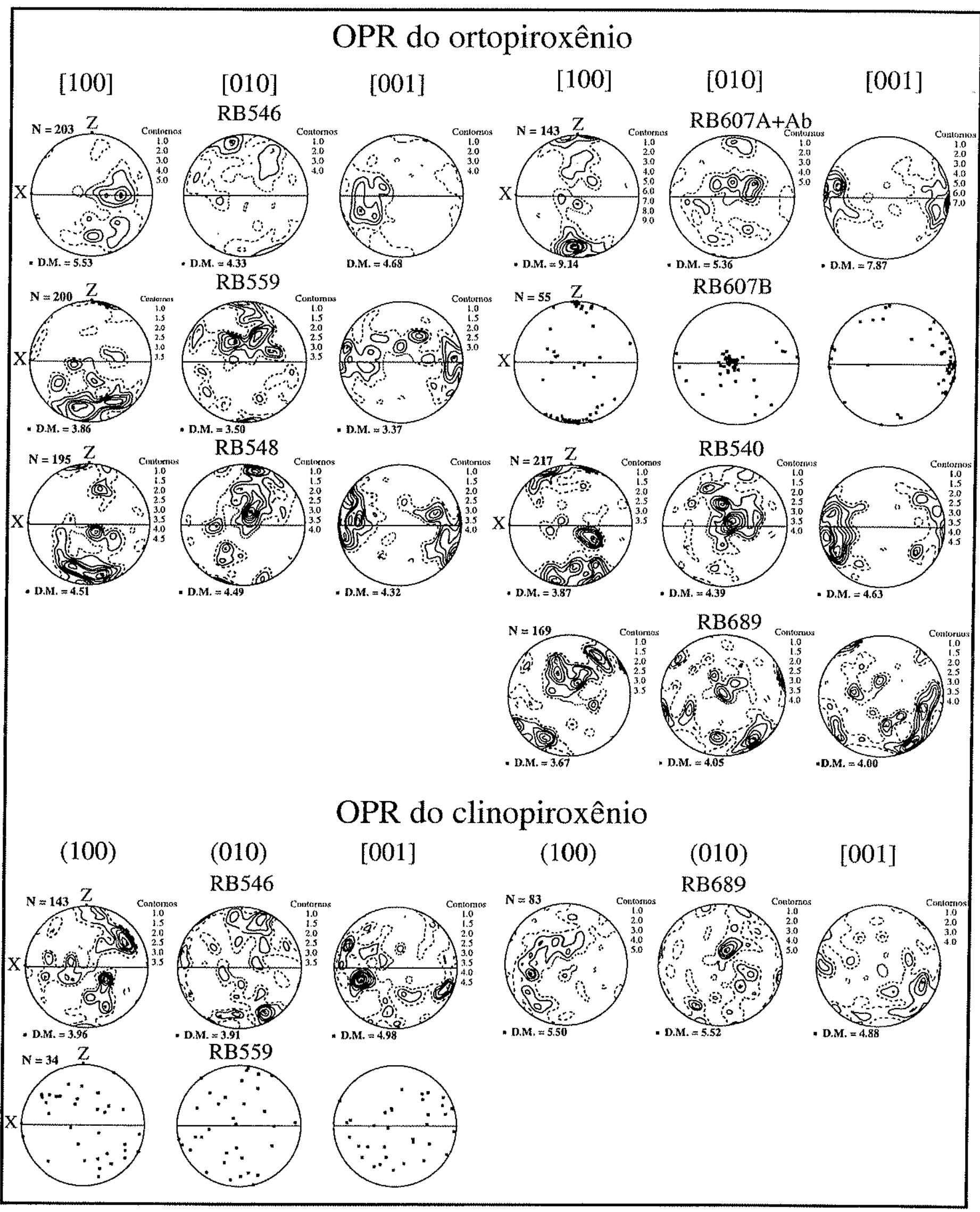

Fig. 4.16. OPR dos piroxênios. Projeção sobre o hemisfério inferior em igual área. A foliação (plano XY; reta plena) está vertical e a lineação $(X)$ é horizontal. Os contornos são em \%; $N$ é o número de medidas; D.M. = densidade máxima. 


\section{OPR de anfibólio}

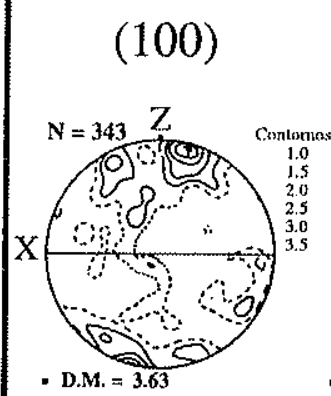

(010)

[001]

(100)

(010)

[001]

RB559

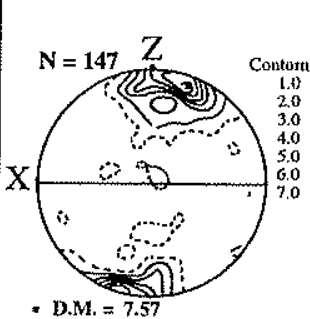

RB548
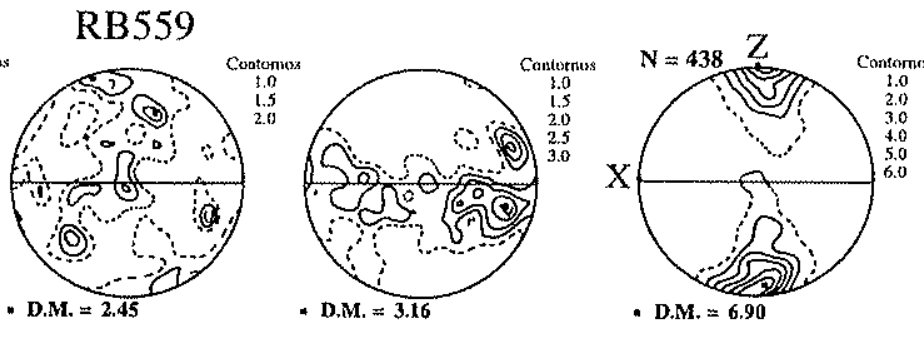

RB609A

- D.M. $=6.90$
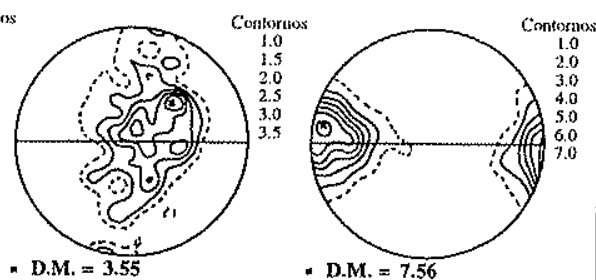

RB607A
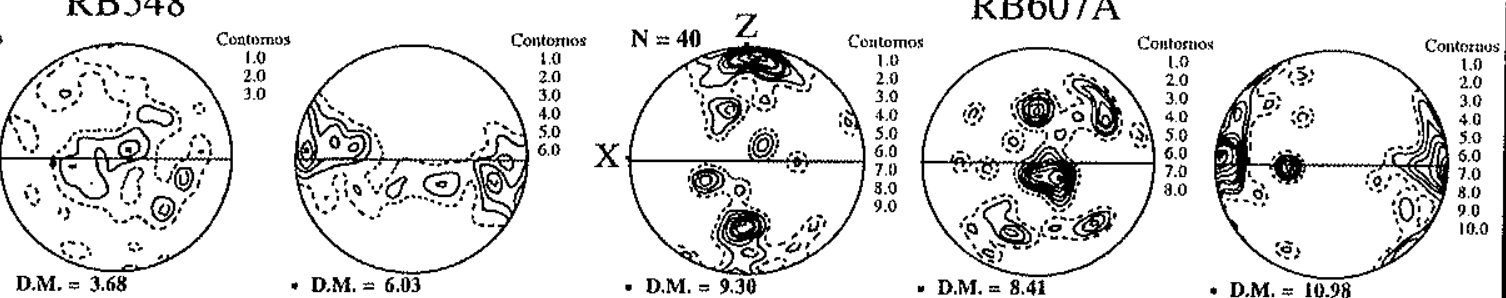

RB614

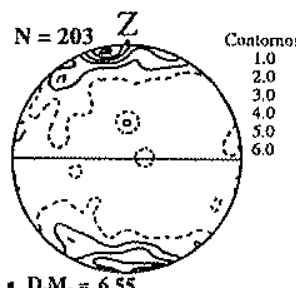

- D.M. $=6.55$
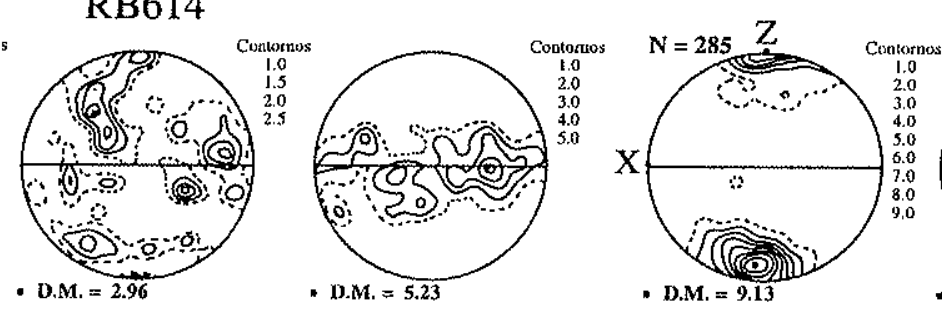

RB566
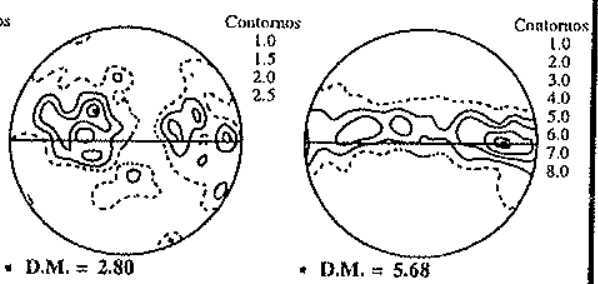

OPR de biotita (eixo c)

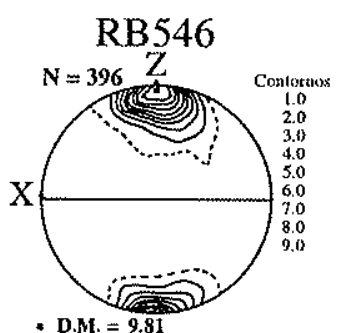

- D.M. = 9.81

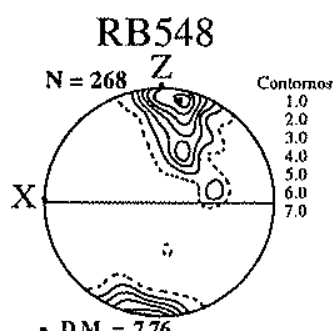

- D.M. $=7.76$
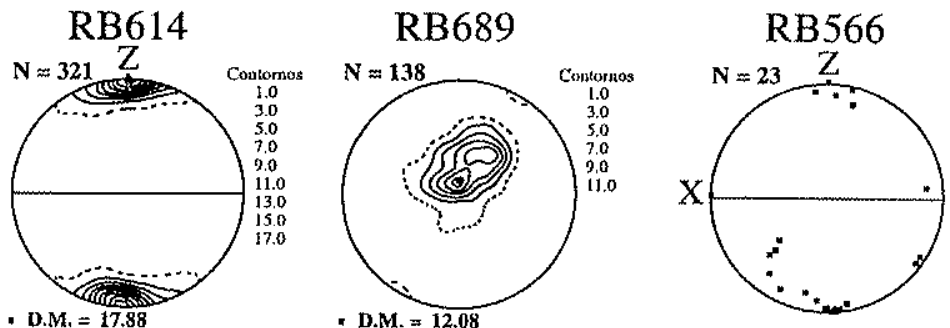

Fig. 4.17. OPR de anfibólios e biotitas. Projeção sobre o hemisfério inferior em igual área. A foliação (plano $X Y$; reta plena) é vertical e a lineação $(X)$ é horizontal. Os contornos são em \%; $N$ é o número de medidas; $D . M$. = Densidade máxima. 
uma forte concentração de [100] perto do eixo $Y$, de [010] perto do eixo $Z$ e de [001] perto do eixo X (amostra RB546) também foi observada por $\mathrm{Ji}_{\mathrm{i}}$ et al. (1993) em um granulito milonítico do Canadá.

As microestruturas e as OPR do anfibólio também são similares àquelas que são reportadas por Ji et al. (1993). A origem desta OPR ainda é discutida, pois as observações de sub-estruturas devidas à deformação por fluxo são escassas. As observações através da microscopia eletrônica (Reynard et al., 1989) sugerem que a trama do anfibólio nos milonitos é produzida pelo deslizamento sobre os sistemas (100) [001] acomodado por recristalização. Um forte crescimento anisotrópico do anfibólio sin-metamórfico poderia também conduzir ao desenvolvimento do alongamento dos cristais.

\subsection{Processos sin- e pós-cinemáticos nos milonitos de alta temperatura: discussão e conclusão}

A faixa Ribeira, no SE do cráton do São Francisco, é caracterizada por deslocamentos de escala litosférica que resultaram de uma convergência entre os crátons do São Francisco e do Congo, no Neoproterozóico. Na região de Santo Antônio de Pádua, as transcorrências são paralelas à faixa e formam uma espessa zona milonítica. As rochas säo intensamente foliadas, muitas vezes bandadas, e possuem geralmente uma lineação bem marcada. Grandes maciços intrusivos (série dos charnockitos) no contato com os milonitos mostram estruturas com a mesma direção que a dos milonitos. A análise da assimetria das figuras sugere uma cinemática dextral. As pressões - temperaturas estimadas indicam uma milonitização sob condições de fácies granulito. As temperaturas estimadas variam entre $750^{\circ} \mathrm{C}$ e $850^{\circ} \mathrm{C}$, e as pressões não puderam ser avaliadas com precisão, mas poderiam ser baixas $(\leq 700 \mathrm{MPa}$, Porcher et al., 2000). Em escala de afloramento é observada uma partição da deformação. Os marcadores estruturais e metamórficos destacados para os afloramentos da região de estudo indicam uma zona de milonitos granulíticos formados por trancorrências dextrais ativas sob regime de deformação transpressivo.

As microestruturas e as OPR nos milonitos da região de Santo Antônio de Pádua evidenciam um intenso fluxo das rochas. As paredes de discordância e as bandas de dobramento nos porfiroclastos de ortopiroxênio, a recristalização dinâmica do plagioclásio ou ainda o crescimento exagerado dos limites de grão do quartzo são microestruturas típicas de 
uma deformação ativa sob temperaturas muito altas, provavelmente superiores a $800^{\circ} \mathrm{C}$, e de um resfriamento lento.

As microestruturas do quartzo nos milonitos traduzem a extrema mobilidade dos limites de grão durante e depois da deformação. O crescimento que geraram "os ribbons" poderia estar correlacionado com a temperatura na transição entre o quartzo- $\alpha$ e o quartzo- $\beta$ (ver p. ex., Joesten, 1983; Wirth, 1985). Os "platten-quartz" são estruturas relativamente instáveis e, nos milonitos estudados, a ausência de sub-estruturas significativas e de recristalização dinâmica afetando os "ribbons" de quartzo, sugere que estas rochas não sofreram uma deformação importante após o "annealing" pós-cinemático.

A OPR dos grãos de quartzo que constituem "os ribbons" de espessura plurimilimétrica apresentam características que se encontram na maioria dos milonitos, particularmente a orientação dos planos (r) com um máximo de concentração dos pólos subperpendiculares a foliação e um segundo máximo menos marcado sub-paralelo a lineação. Portanto, esta OPR é provavelmente associada com o "annealing" do quartzo. As OPR de quartzo dos eixos-c e dos eixos-a nos milonitos estariam compatíveis somente com uma deformação a baixa temperatura, o que não está de acordo com a microestrutura observada e com as calibrações P-T Somente algumas OPR caracterizadas por concentrações dos eixos-c perto do eixo estrutural $\mathrm{Y}$ e dos eixos-a perto da lineação sugerem a ativação do sistema $\{10 \overline{1} 0\}<a>$ que pode dominar sob condições de temperaturas relativamente altas; estas OPR poderiam corresponder à fábrica sin-cinemática não modificada pelo "annealing". Porém, as OPR dos eixos-c entre X e Y, provavelmente associadas com o "annealing" do quartzo, aparecem como desprovidas de qualquer informação sin-cinemática.

A OPR do ortopiroxênio, do anfibólio e do plagioclásio indicam que estes minerais foram deformados por fluxo de discordâncias com a ativação dominante do sistema (100) [001] para o ortopiroxênio e o anfibólio, e (010) [100] para o plagioclásio. Para este último mineral, um grande número de sistemas de deslizamento secundários como (010) [001] e (001) [100] parece estar associado com a ativação do sistema dominante. O deslizamento intracristalino e o desenvolvimento das OPR no ortopiroxênio, anfibólio e plagioclásio são correlacionados com a milonitização sob condições térmicas elevadas. 


\section{Capítulo 5.}

\section{Orientações preferenciais da rede dos óxidos "ilmenita - hematita" e anisotropia magnética nos milonitos de alta temperatura}

\subsection{Resumo}

A Faixa Ribeira em sua porção central, é cortada por zonas de cisalhamento de largura quilométricas, caracterizadas por uma deformação de alta temperatura. Estudos sobre as tramas cristalográficas e magnéticas foram realizados em granulitos miloníticos. Nestas rochas, um forte bandamento composicional realça a foliação tectônica, e a elongação dos cristais do anfibólio, do ortopiroxênio e dos óxidos de Fe-Ti definem a lineação.

A trama magnética deduzida através das medidas da anisotropia de susceptibilidade magnética (ASM) é perfeitamente compatível à trama tectônica. Estudos sobre o magnetismo de rocha mostram que tanto os minerais paramagnéticos como os ferromagnéticos são os responsáveis pela ASM. A anisotropia da magnetização remanente isotermal, a qual é devida à orientaçăo preferencial de forma dos grãos de magnetita, é coaxial à ASM.

As medidas da orientação preferencial da rede cristalina (OPR), as quais foram feitas através do EBSD, mostram que os ortopiroxênios, anfibólios, biotitas e os óxidos da solução solida ilmenita - hematita (ou titanohematita) possuem uma forte OPR, a qual esta relacionada à trama tectônica. Entre este minerais, os óxidos de Fe-Ti são os únicos minerais presentes, relativamente em grande proporções $(>1.5 \%)$, em todas as amostras estudadas.

A OPR da titanohematita é caracterizada por uma forte concentração dos pólos de (0001) ou eixos-c, sub-perpendiculares à foliação e por uma distribuição dos pólos dos planos prismáticos $(2 \overline{110})$ e $(10 \overline{10})$ ao longo do plano da foliação, com um máximo próximo à lineação. Esta OPR é interpretada como resultado do fluxo de discordância (dislocation creep) durante a milonitização. Há um bom ajuste entre a trama magnética e a OPR da titanohematita, o eixo de susceptibilidade magnético mínimo $\left(\mathrm{K}_{3}\right)$ esta alinhado com a máxima concentração dos eixos-c e, o eixo de máxima susceptibilidade $\left(\mathrm{K}_{1}\right)$ coincide com a máxima concentração dos pólos dos planos prismáticos. A OPR da titanohematita pode fornecer um valioso apoio para a interpretação cinemática das tramas magnéticas.

Ver artigo "Titanohematite lattice preferred orientation and magnetic anisotropy in high-temperature mylonites" no anexo III. 


\section{Capítulo 6.}

\section{Propriedades sísmicas}

\subsection{Introdução}

As grandes zonas de cisalhamento acomodam uma parte importante da deformação induzida na crosta continental pelos processos da tectônica das placas. A compreensão da estrutura profunda destes grandes acidentes é portanto indispensável para tornar os modelos geodinâmicos mais precisos. Nos últimos anos, várias técnicas sismológicas foram desenvolvidas e têm permitido traduzir em imagem, de modo cada vez mais preciso, as estruturas profundas das falhas litosféricas. Tal é o caso, por exemplo, das técnicas de sísmica de reflexão e do estudo da birrefringência das ondas $S$ telessísmicas.

As técnicas de sísmica de reflexão colocam em evidência, ao longo dos grandes perfis (COCORP, ECORS, CROP, etc), zonas altamente refletivas até a crosta inferior (ver referências de algumas dessas falhas em Jonas e Nur (1984) e mesmo ultrapassando a Moho, penetrando no manto superior (McGeary, 1989; Diaconescu et al., 1997). Estes refletores sísmicos podem estar muito inclinados ou formar uma rede anastomosada pouco inclinada (Fountaine et al., 1984); eles estão frequëntemente situados sob as grandes zonas miloníticas e são portanto associados a zonas de falha. Todavia, a origem das reflexões sísmicas observadas ainda é muito discutida. As rochas com foliação penetrativa e ricas em filossilicatos poderiam constituir bons refletores sísmicos (p. ex., Christensen, 1989; Barruol e Mainprice, 1993a). No entanto, a situação é menos clara para as rochas quartzo-feldspáticas milonitizadas em condições granulíticas que escaparam às mudanças mineralógicas ligadas ao retrometamorfismo (por exemplo, feldspatos em micas). Diferentes fatores suscetíveis de se combinarem foram sugeridos para explicar as reflexões sísmicas associadas às zonas de cisalhamento na crosta profunda : i) um altenância repetitiva de camadas de espessura plurimétrica caracterizadas por impedâncias acústicas contrastadas (Jones e Nur, 1984; Rey et al., 1994); ii) a justaposição das rochas milonitizadas e de seu protólito (p. ex., Christensen e Szymanski, 1988); iii) contrastes litológicos atribuídos à atividade das falhas; iv) constrastes de densidade entre inclusões e as rochas vizinhas (enclaves básicos em granitos ou charnockitos; Fountain et al., 1994; Ji et al., 1997) ou ainda, v) a presença de fases aquosas livres com uma porosidade estratificada (Jones e Nur, 1984). 
$O$ estudo da birrefringência das ondas $S$ é cada vez mais utilizado para investigar os meios anisotrópicos profundos. Esta abordagem baseiamse no fenômeno de polarização de uma onda de cisalhamento em duas ondas ortogonais que se propagam com velocidades diferentes em um meio anisotrópico (seção 1.4.2.3). A análise da defasagem das ondas $\mathrm{S}$ telessísmicas, por exemplo, as ondas SKS (conversão de onda $\mathrm{P}$ em onda $\mathrm{S}$ na fronteira núcleo-manto), permite determinar a anisotropia sob uma estação com uma resolução lateral de cerca de $50 \mathrm{~km}$ (Mainprice e Silver, 1993; Barruol et al., 1997). Esta boa resolução é devida ao trajeto quase vertical das ondas SKS através do manto e da crosta. Em geral, os grandes deslizamentos litosféricos são caracterizados por uma onda rápida paralela à direção da falha (por exemplo, Ansel e Nataf, 1989) e uma defasagem temporal considerável (ou atraso, $\delta \mathrm{t}$ ) entre o tempo de chegada da onda rápida e lenta (>1.2 s, Herquel et al., 1999), que são principalmente devidas à deformação que tais falhas induzem no manto litosférico (Vauchez e Tommasi, 2002). Todavia, a contribuição da crosta permanece difícil de ser quantificada por uma abordagem estritamente sísmica (McNamara e Owens, 1993; Herquel et al., 1995).

A interpretação dos resultados obtidos graças a todas estas técnicas sísmicas depende do conhecimento das propriedades sísmicas das rochas. Na seção seguinte, as propriedades sísmicas de quatro milonitos e de um gnaisse enderbítico coletados ao longo do perfil transversal às falhas dúcteis da região de Santo Antônio de Pádua (Fig. 4.3) são calculadas. Tais resultados permitiram abordar dois problemas complementares: i) o papel da milonitização na refletividade das zonas de cisalhamento na crosta média e inferior. ii) a contribuição da crosta à defasagem das ondas $\mathrm{S}$ nos domínios das transcorrências litosféricas.

\subsection{As propriedades sísmicas}

\subsubsection{Monocristais e agregados monofásicos}

As propriedades sísmicas dos monocristais foram calculadas utilizando-se as matrizes das constantes elásticas estabelecidas à temperatura ambiente por : McSkimin et al. (1965) para o quartzom $\alpha$, Aleksandrov et al. (1974) para o plagioclásio e o feldspato-K (microclínio), Aleksandrov e Ryzhova (1961) para a homblenda e a biotita, Collins e Brown (1998) para o clinopiroxênio, e Weidner et al. (1978) e Bass e Weidner (1984) para o ortopiroxênio. As 
propriedades elásticas do quartzo- $\beta$ a $700^{\circ} \mathrm{C}$ e $800^{\circ} \mathrm{C}$ foram determinadas por Kammer et al. (1948). A distribuição das velocidades sísmicas das ondas P e S da maioria desses monocristais esta representada na Fig. 6.1 na forma de projeção de igual área em um referencial cristalográfico. Com exceção do quartzo- $\beta$, os monocristais são altamente anisotrópicos: para as ondas $\mathrm{P}, 19.7 \% \leq \mathrm{AVp} \leq 64.3 \%$. Para as ondas $\mathrm{S}, 15.12 \% \leq \mathrm{AVs}$ máx $\leq$ 113.75\%; AVs máx sendo a anisotropia de polarização calculada a partir da birrefringência máxima (AVs máx = (Vs1 - Vs2)máx / (Vs1 + Vs2) /2)).

Como exemplo, as propriedades sísmicas das principais fases minerais que constituem o milonito RB607A são apresentadas na Fig. 6.2. Esta ilustração mostra as propriedades sísmicas dos diferentes agregados monofásicos e depois, por composição, da rocha polifásica. Os cálculos das matrizes dos coeficientes elásticos são realizados utilizando-se a hipótese de Voigt (deformação uniforme).

\subsubsection{O quartzo}

As velocidades médias das ondas $P$ são centradas em torno do eixo-c e Vp máx é próxima da normal ao plano do romboedro (z). Para as ondas de cisalhamento, o eixo-a e o eixo-c são direções de alta velocidade (Vs1 elevada) e Vs2 máx é paralela ao eixo-c. As propriedades sísmicas do quartzo- $\alpha$ refletem a estrutura de simetria romboédrica do cristal. As propriedades sísmicas do monocristal de quartzo- $\beta$, que é a forma estável do quartzo sob pressão atmosférica e para temperaturas superiores a $573^{\circ} \mathrm{C}$, também são apresentadas na Fig. 6.1. A distribuição das velocidades mostram uma simetria axial, e a passagem do quartzo- $\alpha$ ao quartzo- $\beta$ é marcada por um grande decréscimo da anisotropia sísmica (de $27.7 \%$ para $4.3 \%$ na anisotropia azimutal AVp é de $43.2 \%$ para $14.5 \%$ no caso da anisotropia de polarização AVs máx).

As velocidades médias das ondas $P$ estão centradas em torno do eixo-c e Vp máx é próxima da normal ao plano do romboedro (z). Para as ondas de cisalhamento, os eixos-a e c são direções de alta velocidade (Vs1 elevada) e Vs2 máxima é paralela ao eixo-c. As propriedades sísmicas do quartzo- $\alpha$ refletem a estrutura de simetria romboédrica do cristal. As propriedades sísmicas do monocristal de quartzo- $\beta$, que é a forma estável do quartzo sob pressão atmosférica e para temperaturas superiores a $573^{\circ} \mathrm{C}$, também são apresentadas na Fig. 6.1. A distribuição das velocidades tem uma simetria axial, e a passagem do quartzo- $\alpha$ ao quartzo- $\beta$ é marcada por um grande decréscimo da anisotropia sísmica (de $27.7 \%$ para $4.3 \%$ 
em relação a anisotropia azimutal AVp é de $43.2 \%$ para $14.5 \%$ na anisotropia de polarização AVs máx).

As propriedades sísmicas do agregado de quartzo (quartzo- $\alpha$ ) da amostra RB607A apresentadas na Fig. 6.2 são representativas dos "ribbons" de quartzo. A distribuição das velocidades sísmicas no referencial estrutural é calculada a partir das propriedades sísmicas do monocristal e das OPR de quartzo. Esta é caracterizada por uma concentração preferencial dos eixos-c entre os eixos $\mathrm{X}$ e $\mathrm{Z}$, a $45^{\circ}$ de $\mathrm{Z}$, e por uma distribuição bimodal dos eixos do romboedro (r), com um primeiro máximo sub-perpendicular à foliação e um segundo máximo, menos intenso, sub-paralelo à lineação. A distribuição das velocidades sísmicas apresenta relações complexas com o referencial estrutural. A velocidade máxima das ondas $\mathrm{P}$ está localizada em posição intermediária entre os eixos $\mathrm{X}, \mathrm{Y}$ e Z, e a velocidade mínima (Vp mín) tende a ser paralela à lineação. A birrefringência máxima encontra-se em uma posição intermediária entre o eixo $Z$ e o eixo $X$, próxima do máximo de concentração dos eixos-c. A anisotropia sísmica é relativamente alta $(A V p=5.9 \%$ e $A V s$ máx $=6.4 \%$, Fig. 6.2). A birrefringência tem uma distribuição complexa e o mínimo é paralelo ao eixo-c. As orientações dos planos de polarização da onda de cisalhamento rápido têm igualmente uma distribuição complexa sem relação simples com os eixos cristalográficos. Ao redor do eixo Y, as direções dos planos de polarização são orientadas a cerca de trinta graus da lineação.

\subsubsection{O plagioclásio}

As propriedades sísmicas dos monocristais de plagioclásio foram calculadas utilizando-se a matriz reduzida à simetria monoclínica de Aleksandrov et al. (1974). As velocidades rápidas das ondas $\mathrm{P}$ estão concentradas em torno do eixo [010], as velocidades normais ao plano (001) são elevadas, e as velocidades mais lentas são próximas do pólo do plano (100). As ondas $S$ caracterizam-se por velocidades mínimas (Vs1 mín e Vs2 mín) perpendiculares ao plano (001). O pólo dos planos (001) e (100) é uma orientação de baixa birrefringência e o pólo do plano (010) é associado a uma alta birrefringência. O plagioclásio mostra uma anisotropia sísmica intrínseca elevada ( $\mathrm{AVp}=34.3 \%$ e AVs máx $=33.5 \%$ para An 24). As orientações dos planos de polarização da onda $S$ rápida mostram uma orientação complexa em relação aos eixos da deformação finita.

As velocidades elevadas ( $>6 \mathrm{~km} / \mathrm{s}$ ) das ondas $\mathrm{P}$ entre o eixo $\mathrm{Z}$ e $\mathrm{Y}$ para o agregado de plagioclásio (Fig. 6.2) refletem a orientação preferencial dos planos (010). Ao contrário da 
distribuição das ondas $P$, os diferentes máximos de birrefringência das ondas $S$ não apresentam relações simples com os eixos $X, Y$ e Z. Os planos de polarização da onda $S$ rápida em torno do eixo $Y$ são sub-perpendiculares à foliação.

\subsubsection{O ortopiroxênio}

As propriedades sísmicas do monocristal de hiperstênio (50\% enstatita, $50 \%$ ferrosilita) refletem a simetria ortorrômbica do cristal. Vp máx é paralela ao eixo [100] e Vp mín é paralela ao eixo [010] A birrefringência é muito baixa em torno dos eixos [100], [010] e [001], e entre estes eixos, quatro máximos de birrefringência estão dispostos a $90^{\circ}$ uns dos outros. A anisotropia sísmica do ortopiroxênio é relativamente fraca em comparação com os outros monocristais $(\mathrm{AVp}=14.9 \%$ e AVs máx $=15.1 \%$ ). Os planos de polarização têm uma repartição homogênea centrada em [001].

As relações entre as propriedades sísmicas do agregado de hiperstênio e os eixos da deformação finita são simples (Fig. 6.2). Vp máx é paralela a $\mathrm{Z}$ e as velocidades das ondas $\mathrm{P}$ são baixas ao longo do plano da foliação. Esta distribuição das velocidades das ondas $\mathrm{P}$ é correlata com a orientação preferencial dos eixos [100] paralelos a Z, dos eixos [010] paralelos ao eixo $\mathrm{Y}$ e dos eixos [001] paralelos a X. A birrefringência das ondas S é elevada paralelamente a $\mathrm{Z}$ e fraca no plano de foliação. A anisotropia sísmica do agregado é pouco intensa $(\mathrm{AVp}=2.3 \%$ e $\mathrm{AVs}$ máx $=2.9 \%)$. Os planos de polarização Vs1 mostram uma repartição homogênea. Em torno do eixo $Y$, a direção do plano de polarização $V$ s1 é paralela à lineação.

\subsubsection{O anfibólio}

O monocristal de hornblenda (Fig. 1.6) é caracterizado por uma velocidade de propagação das ondas $\mathbf{P}$ máxima próxima do pólo do plano (001) e mínima em torno do pólo do plano (100). Do mesmo modo, os mais altos valores de birrefringência das ondas $S$ estão concentrados próximo do pólo do plano (001) e os mais baixos estão ao redor do pólo do plano (100). As anisotropias sísmicas AVp e AVs máx são muito altas: $A V p=27.1 \%$ e AVs máx $=30.8 \%$. As orientações dos planos de polarização da onda $S$ rápida mostram uma orientação complexa em relação aos eixos $\mathrm{X}, \mathrm{Y}$ e Z.

Para o agregado de anfibólio (Fig. 6.2), as relações entre as propriedades sísmicas e os eixos da deformação finita são simples : Vp máx é paralela à lineação X e Vp mín é paralela a 
Z. Esta distribuição das velocidades das ondas $\mathrm{P}$ está ligada à alta concentração dos eixos [001] paralelamente à lineação e dos pólos dos planos (100) perpendicularmente à foliação. As direções dos planos de polarização Vs1 e a lineação são co-lineares.

\subsubsection{A biotita}

As propriedas sísmicas da biotita são caracterizadas por uma simetria axial (Fig. 6.1). Os valores mais baixos de velocidade de propagação das ondas $\mathrm{P}$ e de birrefringência das ondas $\mathrm{S}$ concentram-se em torno do eixo-c. A anisotropia sísmica da biotita é muito intensa : $\mathrm{AVp}=64.4 \%$ e AVs máx $=113.8 \%$.

Para o agregado de biotita (Fig. 6.2), a velocidade mínima das ondas $\mathrm{P}$ e a birrefringência mínima são perpendiculares à foliação; esta orientação está ligada à concentração do eixo-c perpendicularmente à foliação. A anisotropia do agregado permanece elevada $(A V p=41.2 \%$ e AVs máx $=34.8 \%$, Fig. 6.2). Na zona em que a anisotropia das ondas $S$ é a mais elevada, a direção do plano de polarização da onda $S$ rápida é paralela à lineação.

\subsubsection{As amostras}

O cálculo das propriedades sísmicas das rochas polifásicas, através da equação de Christoffel (seção 1.4.2.), leva em conta a densidade e a matriz de elasticidade média da rocha. Esta é obtida pelo cálculo da matriz de elasticidade e da fração volumétrica de cada fase mineral na rocha. A composição modal é determinada por contagem de pontos. O ritmo da contagem equivale geralmente ao tamanho médio dos grãos e o número de pontos é de cerca de 1500. A densidade da rocha é calculada considerando-se a densidade de cada fase mineral, de acordo com sua proporção modal na rocha.

O cálculo das propriedades sísmicas é realizado para cinco amostras com composições mineralógicas variadas. Estas variações de composição permitem caracterizar as propriedades sísmicas em relação à composição mineralógica da rocha e analisar o efeito da anisotropia sísmica das diferentes fases na anisotropia global. A localização, a descrição petrológica, microestrutural e assim como as OPR das fases silicatadas destas cinco amostras estão apresentadas no Capítulo 4. Para cada amostra, o cálculo das velocidades sísmicas é realizado levando-se em conta unicamente as principais fases silicatadas. A distribuição das velocidades 
esta representada na forma de projeção estereográfica na Fig. 6.3a. Uma síntese dos valores de velocidade e de anisotropia sísmica é apresentada na Fig. 6.1.

O coeficiente de Poisson $(\sigma)$ também é calculado (tabela 6.1). Para um meio anisotrópico, o coeficiente de Poisson exprime-se pela relação:

$$
\sigma=1 / 2\left[1-\frac{1}{(V p / V s)^{2}-1}\right]
$$

A determinação do coeficiente de Poisson é interessante pois o valor de $\sigma$ é freqüentemente correlacionado à composição das rochas. Por exemplo, as medidas realizadas por Siegesmund e Kern (1990) em rochas da crosta média e inferior mostram que as rochas com uma grande proporção em anfibólios têm valores intermediários $(0.25-0.27)$ e as rochas ricas em quartzo possuem coeficientes de Poisson muito baixos (0.21-0.24). Além disso, a amplitude do coeficiente de Poisson é pouco sensível às variações de temperatura e de pressão (Christensen, 1996). Inversamente, em um meio anisotrópico, a amplitude do coeficiente de Poisson poderia ser muito sensível à direção da propagação das ondas sísmicas (Ji e Salisbury, 1993).

\subsubsection{O milonito com hiperstênio e anfibólio (RB607A)}

Para esta amostra, as propriedades sísmicas de cada agregado monofásico, assim como as propriedades sísmicas do agregado polifásico, calculadas considerando-se as proporções volumétricas dos principais minerais que constituem a rocha, estão ilustradas na Fig. 6.2. A distribuição das velocidades sísmicas das ondas $\mathrm{P}$ é muito mais complexa que para os agregados monofásicos. A velocidade das ondas $\mathrm{P}$ parece ser controlada pelas propriedades sísmicas dos dois minerais dominantes: o plagioclásio e o quartzo. O somatório das principais fases minerais tem um efeito destrutivo na anisotropia das ondas $P$ desenvolvida pelo agregado monofásico de quartzo ou de plagioclásio. O agregado polifásico tem uma anisotropia de $2 \%$ enquanto que o agregado de quartzo ou de plagioclásio desenvolve uma anisotropia das ondas $\mathrm{P}$ superiores a $5 \%$.

A birrefringência das ondas $S$ apresenta dois máximos simétricos em relação à foliação, ambos a $45^{\circ}$ de $\mathrm{Z}$. Como para a anisotropia azimutal das ondas $\mathrm{P}$, a anisotropia de polarização das ondas $S$ (AVs máx $=3 \%$ ) da amostra é menos intensa que a desenvolvida pelos agregados de quartzo ou de plagioclásio (AVs máx $>5 \%$ ). Para as direções mais 
anisotrópicas, as ondas Vs1 são polarizadas em um plano paralelo à lineação. Para as ondas Vs1 próximas do eixo $\mathrm{Y}$, a direção do plano de polarização e a lineação formam um ângulo de cerca de $25^{\circ}$.

O coeficiente de Poisson calculado considerando-se a rocha sismicamente isotrópica $\left(\sigma_{\text {iso }}=0.22\right)$ é relativamente baixo em relação aos coeficientes de Poisson determinados pela medida das velocidades sísmicas em laboratório em rochas da crosta profunda $(\sigma>0.24$, Christensen, 1996). Este baixo valor de $\sigma$ está correlacionado à grande proporção de quartzo na rocha. Efetivamente, o plagioclásio e o hiperstênio, que são duas fases presentes em grande proporção na amostra, são caracterizados por um alto coeficiente de Poisson (respectivamente 0.25 e 0.29 para o agregado de hiperstênio e plagioclásio).

\subsubsection{O gnaisse enderbitico (RB559)}

Esta amostra constituída por um grande número de fases minerais (quartzo, plagioclásio $(39<\mathrm{An}<47)$, ortopiroxênio e clinopiroxênio) é largamente dominada pelo plagioclásio (47\% do volume). Os pólos dos planos (010) do plagioclásio desenvolvem uma OPR caracterizada por uma meia-guirlanda com um máximo em $\mathrm{Z}$ e um sub-máximo em posição intermediária entre os três eixos X, Y e Z (Fig. 4.13). Os pólos dos planos (001) também apresentam um máximo em posição intermediátia entre os três eixos $\mathrm{X}, \mathrm{Y}$ e Z. A orientação preferencial dos pólos dos planos (010) e (001) do plagioclásio é responsável pelos máximos de velocidades das ondas $\mathrm{P}$ entre os eixos $\mathrm{Z}$ e $\mathrm{Y}$ da amostra. Apesar das intensas OPR do ortopiroxênio e do anfibólio, a anisotropia das ondas $\mathrm{P}$ resultante é muito baixa (AVp $=1.7 \%$ ). O somatório da anisotropia de cada agregado monofásico tem como consequiência a diminuição da anisotropia desenvolvida pelo agregado de plagioclásio. Para esta amostra, as fases minerais em proporções secundárias têm um efeito destrutivo na anisotropia do mineral principal.

A birrefringência das ondas $S$ mostra uma distribuição complexa em relação ao referencial estrutural (X, Y e Z). A birrefringência é baixa paralelamente à lineação e o eixoY é uma direção de alta birrefringência $(>0.8 \mathrm{~km} / \mathrm{s})$. A distribuição dos planos de polarização da onda $S$ rápida é complexa. Os planos de polarização associados às mais altas birrefringências em torno do eixo-Y são perpendiculares à foliação.

As propriedades sísmicas desta amostra são igualmente calculadas considerando-se as propriedades elásticas do quartzo $\beta$ a $800^{\circ} \mathrm{C}$ (Fig. 6.3b). A distribuição das velocidades das 
ondas $\mathrm{P}$, das ondas $\mathrm{S}$ e dos planos de polarização da onda $\mathrm{S}$ rápida não é modificada. $\mathrm{A}$ velocidade de propagação das ondas $\mathrm{P}$ é mais rápida a anisotropia (AVp) aumenta ligeiramente. Este ligeiro aumento é atribuído à diminuição da anisotropia do agregado de quartzo- $\beta$ em relação ao quartzo- $\alpha$ e portanto a uma diminuição do efeito destrutivo do quartzo na anisotropia sísmica da amostra.

As propriedades sísmicas anisotrópicas da amostra são caracterizadas por velocidade das ondas $P$ elevadas $(\mathrm{Vp}$ iso $=6.82 \mathrm{~km} / \mathrm{s})$ e uma razão de Poisson $\left(\sigma_{\text {iso }}\right)$ de 0.25 . Estes valores calculados concordam com as medidas efetuadas em laboratório por Christensen e Mooney (1995) em rochas de composição mineralógica equivalente. Para as rochas da crosta profunda, valores elevados do coeficiente de Poisson $(0.25-0.27)$ refletem proporções modais em plagioclásio maiores do que as em quartzo (p. ex., Kern e Schenk, 1985).

\subsubsection{O milonito com anfibólio (RB609A)}

As propriedades sísmicas deste milonito são controladas pelo anfibólio que desenvolve uma forte OPR. Os eixos [001] do anfibólio, paralelos à lineação, encontram-se na origem do máximo de velocidade na lineação e a concentração dos pólos dos planos (100) em Z está na origem do mínimo de velocidade perpendicularmente à foliação. Este milonito é altamente anisotrópico $(\mathrm{AVp}=5.8 \%)$.

A birrefringência das ondas $S$ caracteriza-se por máximos em posições intermediárias entre os eixos $\mathrm{X}, \mathrm{Y}$ e $\mathrm{Z}$. A anisotropia das ondas $\mathrm{S}$ é relativamente elevada (AVs máx = $4.7 \%$ ). Os planos de polarização da onda $S$ rápida tendem a se orientar paralelamente à lineação.

Esta amostra caracteriza-se por um elevado coeficiente de Poisson $\left(\sigma_{\text {iso }}=0.27\right)$. Levar em consideração as propriedades sísmicas anisotrópicas, tem uma influência considerável no valor do coeficiente de Poisson. Por exemplo, o cálculo efetuado por uma onda sísmica que se propaga perpendicularmente à foliação revela um valor do coeficiente de Poisson de 0.26.

\subsubsection{O milonito de composição granítica $(R B 609 C)$}

O quartzo representa $50 \%$ do volume da rocha. A velocidade de propagação máxima das ondas $\mathrm{P}$, entre o eixo $\mathrm{Z}$ e $\mathrm{X}$, corresponde ao máximo de concentração dos eixos-c do quartzo. A velocidade mínima das ondas $\mathrm{P}$ é correlata à orientação dos pólos dos planos 
prismáticos (a e m) próximos da lineação. A anisotropia das ondas $\mathrm{P}$ é relativamente alta $(\mathrm{AVp}=5 \%)$.

A birrefringência das ondas $S$ apresenta uma simetria de distribuição monoclínica com um único máximo na zona de birrefringência isto é, no plano da foliação, entre os eixos X e Z. A birrefringência máxima corresponde a uma anisotropia de $7 \%$. Os planos de polarização da onda S rápida apresentam uma distribuição complexa em relação ao referencial estrutural. As ondas S com uma direção de propagação na foliação, polarizam-se com uma direção de onda rápida perpendicular à lineação.

As propriedades sísmicas desta amostra foram calculadas considerando-se as propriedades elásticas do quartzo $\beta$ a $700^{\circ} \mathrm{C}$ (Fig. 6.3b). Modificações importantes são observadas em relação às propriedades sísmicas calculadas com as propriedades elásticas do quartzo- $\alpha$ (Fig. 6.3a). As velocidades de propagação aumentam muito e a anisotropia da amostra diminui $(\mathrm{AVp}=2.2 \%)$. A distribuição da birrefringência é totalmente modificada: as direções de alta e de baixa birrefringência são invertidas no curso da transição entre o quartzo$\alpha$ e o quartzo- $\beta$. Além disso, as direções dos planos de polarização da onda $S$ rápida tendem a se orientar a $45^{\circ}$ ou a ser co-lineares com a lineação.

As velocidades sísmicas das ondas $\mathrm{P}$ calculadas considerando-se a rocha isotrópica $(\mathrm{Vp}=6.3 \mathrm{~km} / \mathrm{s})$ concordam com as velocidades medidas à temperatura ambiente por Christensen e Mooney (1995) em gnaisses de composição granítica. O baixo valor do coeficiente de Poisson $\left(\sigma_{\text {iso }}=0.18\right)$ está ligado à alta proporção de quartzo na rocha.

\subsubsection{O milonito com hiperstênio (RB540)}

Nesta amostra, o quartzo é a fase dominante. O máximo de velocidade das ondas $\mathrm{P}$ está localizado entre os eixos $\mathrm{X}, \mathrm{Y}$ e Z; esta orientação é controlada pela orientação preferencial do eixo-c do quartzo. A anisotropia da amostra é baixa $(\mathrm{AVp}=2.8 \%)$.

A birrefringência das ondas $S$ mostra uma distribuição complexa em relação ao referencial estrutural $(\mathrm{X}, \mathrm{Y}$ e Z $)$. Os planos de polarização da onda S rápida estão orientados a $45^{\circ}$ da foliação nas direções de mais alta birrefringência.

O cálculo do coeficiente de Poisson para uma direção da onda sísmica perpendicular à foliação $\left(\sigma_{/ / 2}=0.17\right)$ e tomando em consideração o meio como sismicamente isotrópico, $\left(\sigma_{\text {iso }}=0.20\right)$ coloca em evidência valores de $\sigma$ fracos que são correlacionados à alta proporção de quartzo na rocha, e realça a dependência dos valores de $\sigma$ e à anisotropia sísmica do meio. 

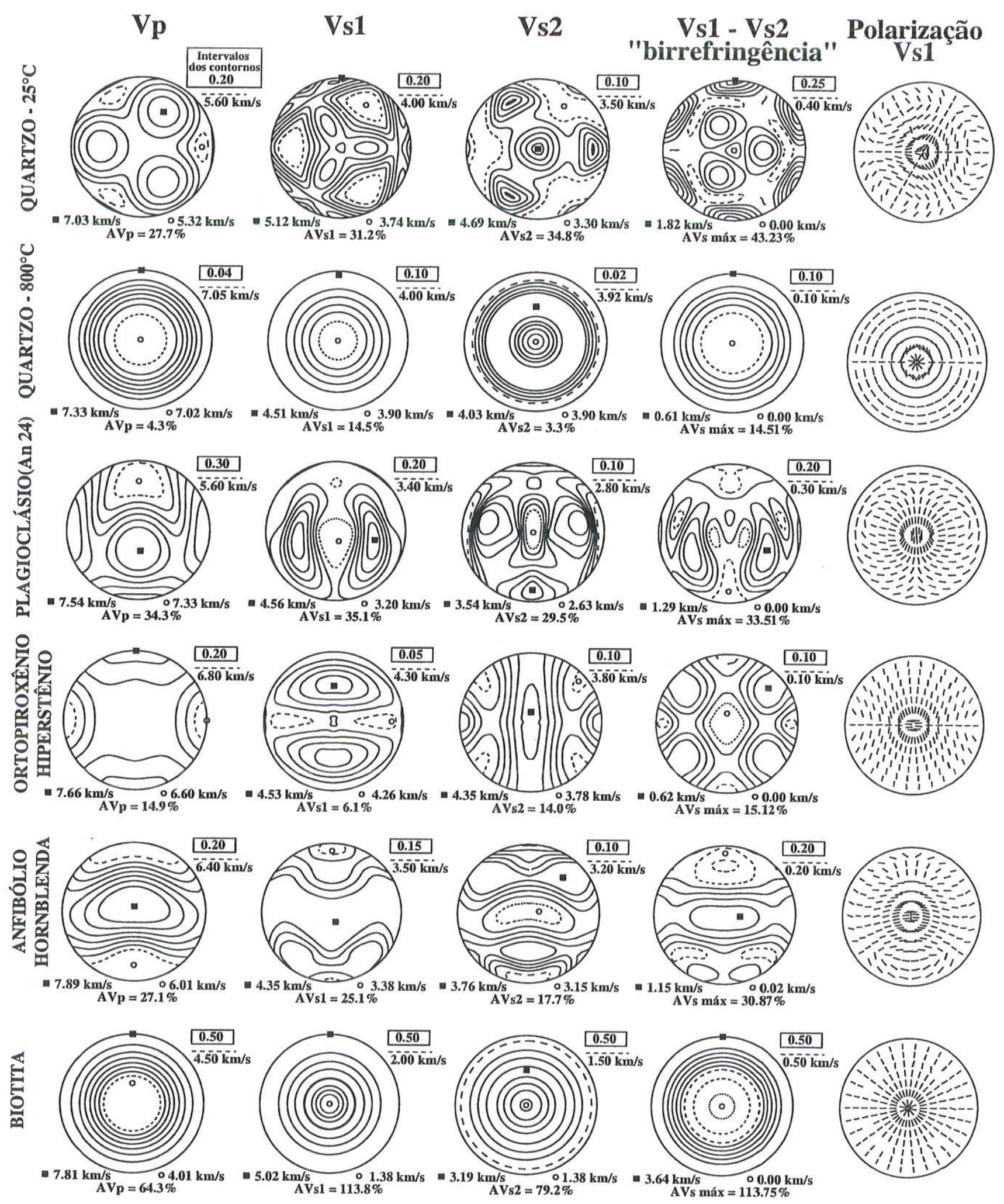

Fig. 6.1. Propriedas sísmicas dos monocristais. Projeção igual área. A velocidade máxima é indicada por um quadrado preto e a velocidade mínima por um círculo branco. AVp ou A Vs : anisotropia das ondas $\mathrm{P}$ e $\mathrm{S}$. Para os minerais ortorrômbicos, a* é equivalente ao eixo-a ou [100]. Para os minerais monoclínicos e triclínicos, $a^{*}$ é equivalente ao eixo perpendicular ao plano (100). Para os minerais hexagonais, b é equivalente Orientação dos
$\begin{gathered}\text { eixos } \\ \text { cristalográficos }\end{gathered}$ ao eixo-m. 

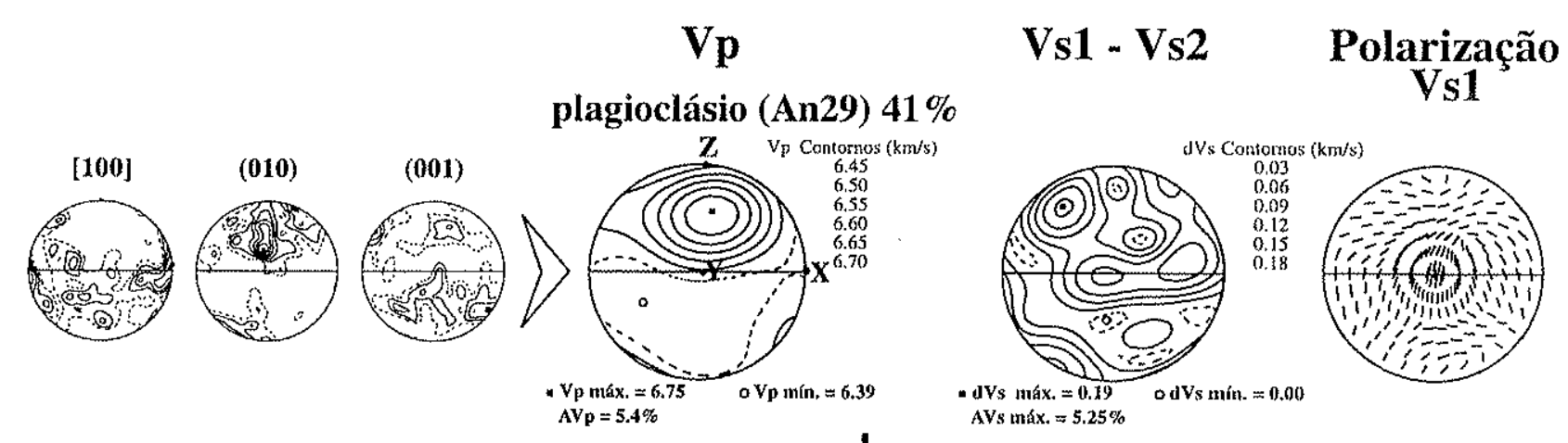

quartzo 33\%
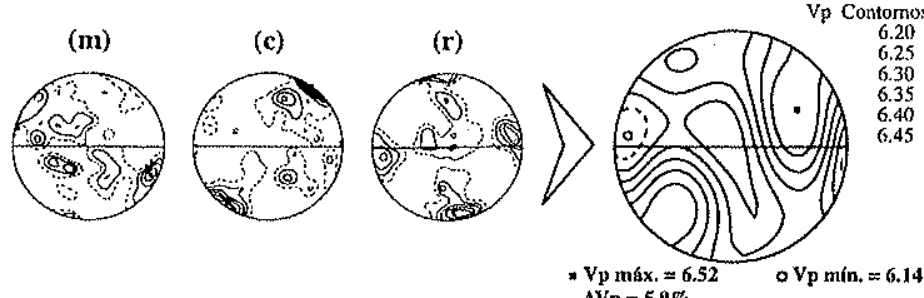
$\operatorname{AV}_{\mathrm{p}}=5.9 \%$

mos $(\mathrm{km} / \mathrm{s})$ AVs tnáx. $=5.25 \%$

\section{hiperstênio $18 \%$ +}
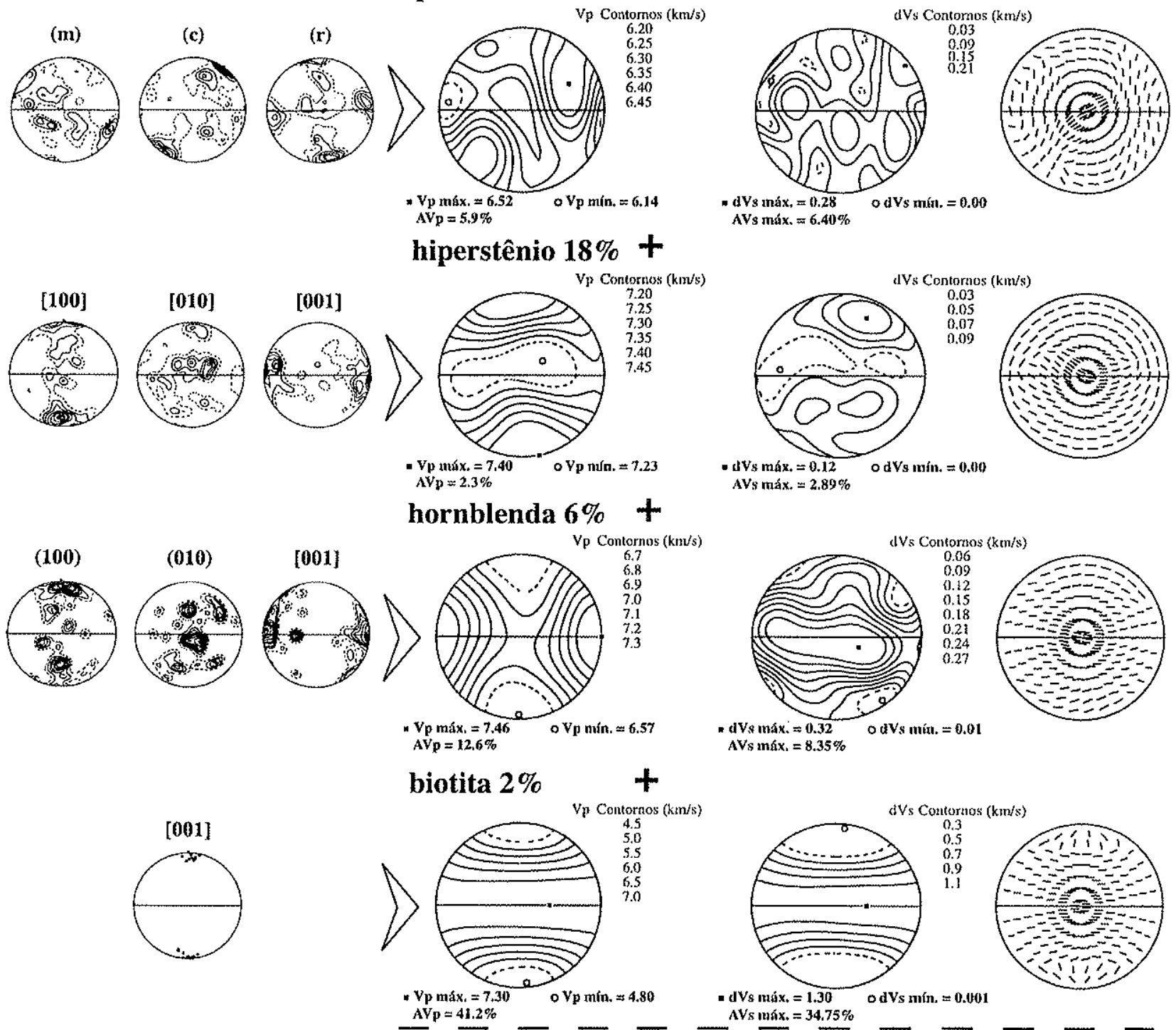

\section{mylonite 607A}

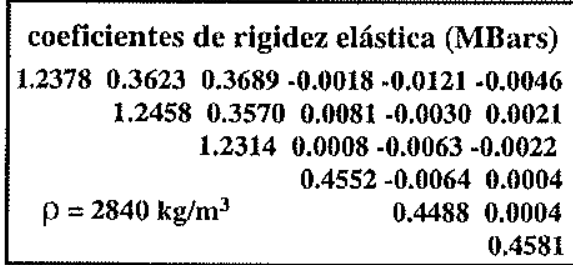
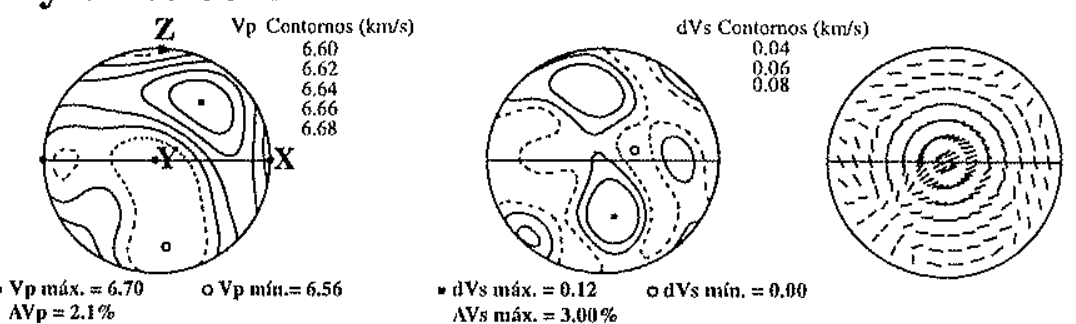

Fig. 6.2. Propriedades sísmicas das fases minerais que constituem a amostra RB607A. As OPR e a proporção de cada fase mineral levada em conta para o cálculo do agregado são indicadas. Projeção igual área no hemisfério inferior. A foliação (XY) é vertical leste-oeste e a lineação (X) é horizontal. 


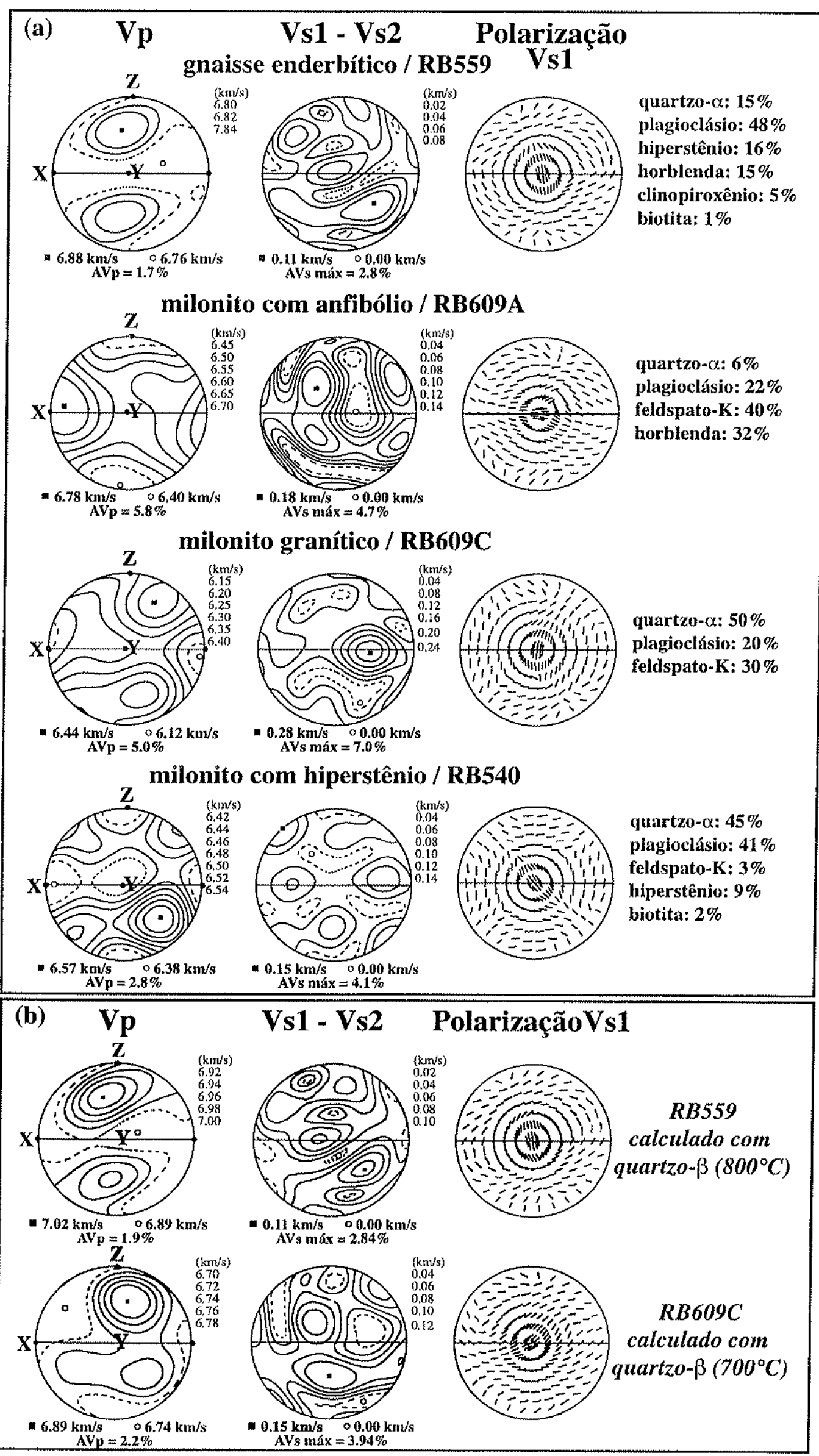

Fig. 6.3. Propriedades sísmicas (a). Quatro amostras da região de Santo Antônio de Pádua. A porcentagem de cada fase mineral levada em conta para o cálculo é indicada. Projeção igual área no hemisfério inferior. $A$ foliação $(X Y)$ é vertical leste-oeste e a lineação $(X)$ é horizontal; (b) Propriedades sísmicas calculadas com o quartzo-b. A porcentagem de cada fase mineral levada em conta para o cálculo é idêntica a (a). 


\begin{tabular}{|c|c|c|c|c|c|c|c|c|c|c|c|c|c|c|c|c|c|c|}
\hline Amostra & $\begin{array}{c}\text { composição modal } \\
(\%)\end{array}$ & $\underset{\left(\mathrm{kg} / \mathrm{m}^{3}\right)}{\text { densidade }}$ & $\underset{(\mathrm{km} / \mathrm{s})}{\mathrm{Vp} \max }$ & $\underset{(\mathrm{km} / \mathrm{s})}{\mathrm{Vp} \min }$ & $\begin{array}{l}\mathbf{V p} / / \mathbf{Z} \\
(\mathrm{km} / \mathrm{s})\end{array}$ & $\underset{(\%)}{\mathbf{A V} \mathbf{p}}$ & $\underset{(\mathbf{k m} / \mathbf{s})}{\text { Vs1 máx }}$ & $\underset{(\mathrm{km} / \mathrm{s})}{\text { Vsl mín }}$ & $\underset{(\mathrm{km} / \mathrm{s})}{\mathrm{Vs} 2 \mathrm{máx}}$ & $\underset{(\mathrm{km} / \mathrm{s})}{\mathrm{Vs2} \operatorname{mí}}$ & $\underset{(\%)}{\text { AVs máx }}$ & $\underset{(\mathrm{km} / \mathrm{s}) / \mathrm{Z})}{(\mathrm{Z})}$ & $(\mathrm{Vp} / \mathrm{Vs})$ & $\sigma / / \mathbf{Z}$ & $V_{p}$ iso & Vs iso & $\begin{array}{c}(\mathrm{Vp} / \mathrm{Vs}) \\
\text { iso }\end{array}$ & o iso \\
\hline RB559 & qtz.15, pl.48, opx.16, & 2909 & 6.88 & 6.76 & 6.80 & 1.7 & 3.99 & 3.89 & 3.94 & 3.84 & 2.8 & 3.95 & 1.721 & 0.25 & 6.82 & 3.91 & 1.742 & 0.25 \\
\hline RB609A & qtz.6, pl.22, Fk.40, hbl.32 & 2720 & 6.78 & 6.40 & 6.40 & 5.8 & 3.80 & 3.62 & 3.71 & 3.59 & 4.7 & 3.66 & 1.749 & 0.26 & 6.59 & 3.68 & 1.790 & 0.27 \\
\hline $\mathrm{RB} 609 \mathrm{C}$ & qtz. 50, pl.20, Fk.30 & 2614 & 6.44 & 6.12 & 6.33 & 5.0 & 4.08 & 3.85 & 3.95 & 3.80 & 7.0 & 4.00 & 1.582 & 0.17 & 6.28 & 3.92 & 1.602 & 0.18 \\
\hline RB607A & $\begin{array}{c}\text { qtz.33, pl.41, opx.18 } \\
\text { hbl.6, bt.2 }\end{array}$ & 2840 & 6.70 & 6.56 & 6.59 & 2.1 & 4.01 & 3.93 & 4.00 & 3.89 & 3.0 & 3.99 & 1.653 & 0.21 & 6.63 & 3.96 & 1.675 & 0.22 \\
\hline RB540 & $\underset{\text { bt. } 2}{\mathrm{qtz} .45, \text { pl. } 4 \mathrm{I}, \mathrm{Fk}, 3, \text { opx.9, }}$ & 2723 & 6.57 & 6.38 & 6.39 & 2.8 & 4.06 & 3.92 & 4.01 & 3.86 & 4.1 & 4.03 & 1.586 & 0.17 & 6.47 & 3.96 & 1.634 & 0.20 \\
\hline
\end{tabular}

Tabela 6.1. Propriedades sísmicas de cinco milonitos. Os cálculos foram realizados levando-se em conta unicamente as principais fases silicatadas. Abreviações dos minerais : qtz. = quartzo; $\mathrm{pl} .=$ plagioclásio; $\mathrm{opx}=$ ortopiroxênio; $\mathrm{hbl}=$ hornblenda; $\mathrm{cpx}=$ clinopiroxênio; bt. = biotita. AVp é a anisotropia sísmica das ondas $\mathbf{P}$, $\mathrm{e}$ AVs máx é a anisotropia sísmica máxima das ondas $S$. Vp iso e Vs iso são respectivamente a velocidade da onda $P$ e $S$ considerando-se a rocha sismicamente isotrópica. Vp iso $=($ Vp máx $+V p$ mín $) / 2$, e Vs iso $=($ Vs1 máx + Vs1 mín + Vs2 máx +Vs2 mín $) / 4$. o é o coeficiente de Poisson. 


\subsection{Refletividade sísmica}

Os coeficientes de reflexão das ondas de compressão e de cisalhamento foram calculados para as diferentes interfaces litológicas possíveis entre as cinco amostras, levandose em consideração os contatos litológicos horizontais e a propagação da onda vertical. $O$ coeficiente de reflexão $(\mathrm{Rc})$ é calculado com o auxílio da equação :

$$
R c=\left(\rho_{1} V_{1}-\rho_{2} V_{2}\right) /\left(\rho_{1} V_{1}+\rho_{2} V_{2}\right)
$$

onde $\rho_{1}$ e $\rho_{2}$ são a densidade das rochas 1 e 2 , e $V_{1}$ et $V_{2}$ são as velocidades das ondas sísmicas nas rochas 1 e 2 .

Para avaliar o papel da milonitização na refletividade sísmica das interfaces entre as cinco amostras estudadas, o cálculo de Rc foi efetuado considerando-se as propriedades anisotrópicas das rochas e também supondo as rochas como sismicamente isotrópicas. Para as ondas $\mathrm{P}$, o cálculo de Rc é igualmente realizado para as interfaces entre os milonitos e seus equivalentes sismicamente isotrópicos (o equivalente não-deformado do milonito). As velocidades isotrópicas podem ser calculadas diretamente introduzindo-se, na equação de Christofell, o equivalente isotrópico da matriz média dos coeficientes de rigidez elástica de cada amostra estudada. As velocidades obtidas são praticamente idênticas às calculadas a partir das velocidades anisotrópicas, levando-se em consideração: i) Vp isotrópica $=(\mathrm{Vp}$ máx $+V p$ mín) / 2, e ii) Vp isotrópica $=V s 1$ máx $+V s 1$ mín $+V s 2$ máx $+V s 2$ mín) / 4. Nos cálculos que levam em conta a anisotropia sísmica das rochas, a velocidade das ondas $\mathrm{P}$ corresponde à velocidade da onda perpendicular à foliação $(/ / \mathrm{Z})$ e a velocidade das ondas $\mathrm{S}$ corresponde à média das duas velocidades Vsl e Vs2, para uma direção de propagação perpendicular à foliação. Os cálculos do coeficiente de reflexão Rc são apresentados nas tabelas 6.2. Para as ondas de compressão, os coeficientes de reflexão calculados com velocidades isotrópicas (tabela 6.2a) têm valores compreendidos entre 0.009 e 0.09 . Dentre os dez coeficientes calculados, quatro têm valores superiores a 0.05 , que é a amplitude limite considerada pelos sismólogos para a deteç̧ão de uma interface. As interfaces mais refletivas são as que estão em contato com o enderbito (RB559). O melhor refletor é a interface entre o enderbito e a amostra de composição granítica (RB609C). Pelo contrário, a interface entre as camadas máficas ricas em anfibólio (RB609A) e as camadas de composição granítica (RB609C) que formam os milonitos bandados, que caracterizam a zona de cisalhamento de Santo Antônio de Pádua, constitui um refletor sísmico fraco $(\mathrm{Rc}=0.044)$. As quatro 
interfaces caracterizadas por um Rc de amplitude compreendida entre 0.05 e 0.09 no caso isotrópico constituem ainda no caso anisotrópico (tabela 6.2b), refletores de qualidade média. As interfaces entre os diversos milonitos e o gnaisse enderbítico constituem os melhores refletores, com uma amplitude máxima de Rc igual a 0.09 para o contato com o milonito de composição granítica, como no caso isotrópico. Com exceção desse último caso, a tomada em consideração da anisotropia aumenta a refletividade dos contatos entre os diversos milonitos $\mathrm{e}$ o gnaisse enderbítico. Ao contrário, a refletividade dos contatos entre os diversos milonitos e aquele com anfibólio (RB609A), diminui de modo significativo em relação à refletividade das interfaces calculada no caso isotrópico. Esta variação do coeficiente de reflexão pode atingir uma amplitude de 0.02 para a interface entre a amostra RB609A e RB609C. O cálculo de Rc realizado para as interfaces entre os milonitos e seus equivalentes isotrópicos (tabela 6.2c) coloca em evidência os mesmos refletores sísmicos que quando o cálculo é efetuado para contatos entre rochas consideradas como isotrópicas (tabela 6.2a) e levando em conta propriedades anisotrópicas das rochas (tabela 6.2b). A amplitude dos coeficientes de reflexão entre os milonitos e seus equivalentes sismicamente (coeficientes em negrito tabela 6.2.c) é muito fraca e aparece como insuficiente para produzir reflexões sísmicas fortes.

Para as ondas de cisalhamento, os coeficientes de reflexão calculados com velocidades isotrópicas (tabela 6.2d) apresentam amplitudes relativamente baixas. O valor de Rc máximo caracteriza a interface entre as amostras RB559 e RB609A $(\mathrm{Rc}=0.064)$. Além disso, apenas três coeficientes de reflexão têm uma amplitude superior a 0.05. A interface entre as amostras RB540 e RB559, cuja amplitude do coeficiente era superior a 0.05 para as onda de compressão, é transparente para as ondas de cisalhamento $(\mathrm{Rc}=0.026)$. Os milonitos bandados RB609 são muito pouco refletivos ( $\mathrm{Rc}$ entre RB609A e RB609C $=-0.012$ ). Considerando-se a anisotropia para o cálculo de Rc (tabela 6.2e) pode-se provocar variações significativas (da ordem de 0.021 ) no coeficiente de reflexão. Todavia, o papel da anisotropia na qualidade de refletor das interfaces permanece complexo pois a anisotropia pode aumentar mais também abaixar a amplitude do coeficiente Rc. 


\begin{tabular}{|c|c|c|c|c|c|c|c|}
\hline \multicolumn{3}{|l|}{ Amostra } & \multirow{3}{*}{$\begin{array}{c}\text { RB559 } \\
2909 \\
682\end{array}$} & \multicolumn{2}{|c|}{ RB609A RB609C } & $\mathrm{RB} 607 \mathrm{~A}$ & \multirow{2}{*}{$\begin{array}{c}\text { RB540 } \\
2723\end{array}$} \\
\hline & lensidade & & & 2720 & 2614 & 2840 & \\
\hline & & $\mathrm{Vp}$ iso. & & 6.59 & 6.28 & 6.63 & 6.47 \\
\hline RB559 & 2909 & 6.82 & $\mathbf{R e} /$ & 0.050 & 0.090 & 0.026 & 0.057 \\
\hline RB609A & 2720 & 6.59 & & / & 0.044 & -0.025 & 0.009 \\
\hline RB609C & 2614 & 6.28 & & & / & -0.068 & -0.035 \\
\hline RB607A & 2840 & 6.63 & & & & / & 0.033 \\
\hline RB540 & 2723 & 6.47 & & & & & 1 \\
\hline
\end{tabular}

Tabela 6.2a. Coeficientes de reflexão ( $R$ c) das ondas $P$ calculados considerando-se os meios como sismicamente isotrópicos. $\mathrm{Vp}$ iso $=$ velocidade isotrópica.

\begin{tabular}{|ccccccccc|}
\hline Amostra & & \multicolumn{1}{c}{ RB559 } & RB609A & RB609C & RB607A & RB540 \\
& densidade & & 2909 & 2720 & 2614 & 2840 & 2723 \\
& & Vp //Z & 6.80 & 6.40 & 6.33 & 6.59 & 6.39 \\
RB559 & 2909 & 6.80 & Re $/$ & 0.064 & 0.090 & 0.027 & 0.064 \\
RB609A & 2720 & 6.40 & & $/$ & 0.025 & -0.036 & 0.000 \\
RB609C & 2614 & 6.33 & & & $/$ & -0.061 & -0.025 \\
RB607A & 2840 & 6.59 & & & & $/$ & 0.036 \\
RB540 & 2723 & 6.39 & & & & & $/$ \\
\hline
\end{tabular}

Tabela 6.2b. Coeficientes de reflexão $(\mathrm{Rc})$ das ondas $P$ calculados utilizando-se as velocidades das ondas $P$ perpendicularmente à foliação $(\mathrm{Vp} / / \mathrm{Z})$.

\begin{tabular}{|lcccccccc|}
\hline Amostra & & isotrope & RB5599 & \multicolumn{3}{c}{ RB609A RB609C } & RB607A & RB540 \\
& densidade & & 2909 & 2720 & 2614 & 2840 & 2723 \\
déformé & & Vp & 6.82 & 6.59 & 6.28 & 6.63 & 6.47 \\
RB559 & 2909 & 6.80 & $\mathbf{R c} \cdot \mathbf{0 . 0 0 1}$ & 0.049 & 0.090 & 0.025 & 0.058 \\
$\boldsymbol{R B 6 0 9 A}$ & 2720 & 6.40 & & $\mathbf{- 0 . 0 1 5}$ & 0.029 & -0.039 & -0.006 \\
RB609C & 2614 & 6.33 & & & $\mathbf{0 . 0 0 4}$ & -0.064 & 0.000 \\
RB607A & 2840 & 6.59 & & & & $\mathbf{- 0 . 0 0 3}$ & 0.030 \\
RB540 & 2723 & 6.39 & & & & & $\mathbf{- 0 . 0 0 6}$ \\
\hline
\end{tabular}

Tabela 6.2c. Coeficientes de reflexão $(\mathbf{R c})$ das ondas $P$ calculados nas interfaces das amostras deformadas e de seus equivalentes isotrópicos.

\begin{tabular}{|ccccccccc|}
\hline Amostra & & & RB559 & RB609A & RB609C & RB607A & RB540 \\
& densidade & & 2909 & 2720 & 2614 & 2840 & 2723 \\
& & Vs iso. & 3.91 & 3.68 & 3.92 & 3.96 & 3.96 \\
\cline { 4 - 8 } & & & & & \\
RB559 & 2909 & 3.91 & Rc $/$ & 0.064 & 0.052 & 0.007 & 0.026 \\
RB609A & 2720 & 3.68 & & $/$ & -0.012 & -0.058 & -0.037 \\
RB609C & 2614 & 3.92 & & & $/$ & -0.046 & -0.026 \\
RB607A & 2840 & 3.96 & & & & $/$ & -0.001 \\
RB540 & 2723 & 3.96 & & & & & $/$ \\
\hline
\end{tabular}

Tabela 6.2d. Coeficientes de reflexão ( $R c)$ das ondas $S$ calculados considerando-se os meios como sismicamente isotrópicos. Vs iso = velocidade isotrópica.

\begin{tabular}{|ccccccccc|}
\hline Amostra & & \multicolumn{1}{c}{ RB559 } & \multicolumn{2}{c|}{ RB609A } & RB609C & RB607A & RB540 \\
& densidade & & 2909 & 2720 & 2614 & 2840 & 2723 \\
& & Vs //Z & 3.95 & 3.66 & 4.00 & 3.99 & 4.03 \\
\cline { 4 - 8 } RB559 & 2909 & 3.95 & Rc $/$ & 0.072 & 0.047 & 0.007 & 0.023 \\
RB609A & 2720 & 3.66 & & $/$ & -0.025 & -0.064 & -0.049 \\
RB609C & 2614 & 4.00 & & & $/$ & 0.040 & -0.024 \\
RB607A & 2840 & 3.99 & & & & $/$ & 0.021 \\
RB540 & 2723 & 4.03 & & & & & $/$ \\
\hline
\end{tabular}

Tabela 6.2e. Coeficientes de reflexão $(\mathrm{Rc})$ das ondas $S$ calculados utilizando-se as velocidades das ondas $S$ perpendicularmente à foliação $(V p / / Z)$.

Unidades

densidade $: \mathrm{kg} / \mathrm{m}^{3}$

Velocidades sísmicas : $\mathrm{km} / \mathrm{s}$ 


\subsection{Contribuição dos milonitos à defasagem das ondas $S$}

A milonitização em condições granulíticas desenvolve uma forte OPR e uma alta anisotropia sísmica de cada fase mineral (Fig. 6.2). No entanto, o cálculo das propriedades sísmicas das rochas totais revela uma anisotropia relativamente baixa: AVs máx $<5.0 \%$ para os milonitos com mais de três fases (Fig. 6.3). Tais resultados concordam com os cálculos de anisotropia sísmica em rochas da crosta profunda efetuados por Barruol e Mainprice (1993a) e que mostram que o número de constituintes da rocha é um fator determinante na intensidade da anisotropia sísmica. Esta diminui quando o número de fases minerais aumenta.

A defasagem temporal $(\delta \mathrm{t})$ das ondas $S$ induzida por um meio anisotrópico é função do comprimento (L) do trajeto da onda no meio anisotrópico (Mainprice e Silver, 1993) e exprime-se pela relação:

$$
\delta \mathrm{t}=\mathrm{LAVs} /\left\langle\mathrm{Vs}_{\mathrm{s}}\right\rangle
$$

A rocha mais anisotrópica é o milonito de composição granítica (RB609C; AVs máx = 7\%). Esta anisotropia de polarização máxima esta localizada no plano da foliação a 45 graus da lineação e, a anisotropia para uma direção paralela ao eixo Y não ultrapassa $3 \%$. Para transcorrências litosféricas e ondas $S$ que se propagam verticalmente através de uma camada de granito milonítico, de $10 \mathrm{~km}$ de largura com uma foliação vertical e uma lineação horizontal, a defasagem temporal seria de 0.076 segundos. De um modo geral, a defasagem temporal das cinco amostras estudadas varia entre $0.0038 \mathrm{~s}$ (RB607A e RB540) e 0.076 s para ondas $S$ que se propagam verticalmente através de uma camada de $10 \mathrm{~km}$ com a foliação vertical e a lineação horizontal. Estas defasagens temporais são baixas em comparação com as que são induzidas por rochas ricas em filossilicatos. Por exemplo, $10 \mathrm{~km}$ de xistos $(25 \%$ de biotita, $25 \%$ de plagioclásio, $25 \%$ de ortoclásio e $25 \%$ de quartzo) com uma foliação vertical e uma lineação horizontal poderiam gerar defasagens temporais de ondas SKS de $0.2 \mathrm{~s}$ (Barruol e Mainprice, 1993b).

A gravação, pelas estações continentais, das ondas telessísmicas $\mathrm{SK}(\mathrm{K}) \mathrm{S}$ mostra defasagens temporais de cerca de $1 \mathrm{~s}$ em média (Silver e Chan, 1988). Esta defasagem tem como fonte principal uma anisotropia sísmica localizada no manto superior. Esta anisotropia sísmica é produzida pela OPR dos minerais do manto (essencialmente a olivina e o ortopiroxênio) que se desenvolvem por deformação das rochas do manto ao curso dos grandes eventos orogênicos presentes e passados (p. ex., Vauchez e Nicolas, 1991). As propriedades sísmicas do manto superior são controladas pelas propriedades elásticas e as OPR da olivina; 
estas, a alta temperatura, são caracterizadas por uma concentração dos eixos [100] paralelos a $X$, os eixos [010] paralelos a $Z$ e os eixos [001] paralelos a $Y$. Estas relações simples entre as OPR da olivina e os eixos principais da deformação finita geram altos valores de birrefringência na foliação com um máximo próximo do eixo Y. A distribuição da anisotropia das ondas $\mathrm{S}(\mathrm{AVs}$ ) para um peridotito sub-continental (harzburgite do maciço de Ronda (Vauchez e Garrido, 2001) esta ilustrada na Fig. 6.4.

Recentemente, as defasagens de grande amplitude (até $2.4 \mathrm{~s}$ ) das ondas SKS foram medidas nas zonas de cisalhamento da faixa Ribeira (Heintz et al., 2002). Para a estação (ALP) situada na zona de cisalhamento de Além Paraíba, a uns cinquienta quilômetros ao SW da zona milonítica estudada (Fig. 4.3), a defasagem é de $1.9 \mathrm{~s}$ e a direção do eixo rápido é colinear à direção da falha ( N070). Para uma estrutura em transcorrência (foliação vertical e lineação horizontal), a defasagem média determinada a partir da anisotropia de polarização das cinco amostras é de cerca de $0.5 \mathrm{~s}$ para uma espessura de $10 \mathrm{~km}$. Nesta região, uma espessura de crosta de $38 \mathrm{~km}$ é estimada por Assunção et al. (2002) a partir da técnica de conversão das ondas P à Moho ("received function"). Se consideramos uma contribuição da crosta da ordem de $0.2 \mathrm{~s}$ assim como uma possível participação máxima de $0.2 \mathrm{~s}$ da zona de transição entre o manto superior e inferior (p. ex., Mainprice e Silver, 1993), a anisotropia do manto superior deve estar na origem de um $\delta$ t minimum de $1.5 \mathrm{~s}$. Para obter tal defasagem a partir de rochas do manto, com propriedades sísmicas comparáveis às do peridotito subcontinental representadas na Fig. 6.4, é necessário que a onda SKS, de propagação vertical, atravesse uma espessura de manto, com uma foliação vertical e uma lineação horizontal, de $120 \mathrm{~km}$. A espessura atravessada deverá ser maior na medida em que o mergulho da foliação for menor (190 km para uma foliação de $45^{\circ}$ e lineação horizontal e $249 \mathrm{~km}$ para uma foliação e uma lineação horizontais, estrutura típica para um fluxo astenoférico). Um modelo simples constituído por uma espessura de crosta de cerca de $38 \mathrm{~km}$ e por uma camada de peridotito anisotrópica com uma espessura inferior a $160 \mathrm{~km}$ é coerente com os modelos tomográficos efetuados por (Heintz et al., 2000) que mostram uma ausência de anisotropia abaixo de $200 \mathrm{~km}$ na escala do continente sul americano. Nossos cálculos relativamente simples de $\delta \mathrm{t}$ e de espessura de material anisotrópico sugerem que as transcorrências e o manto subjacente são co-estruturados e que as zonas de cisalhamento que estão na origem dos milonitos enraizam-se profundamente no manto superior. 

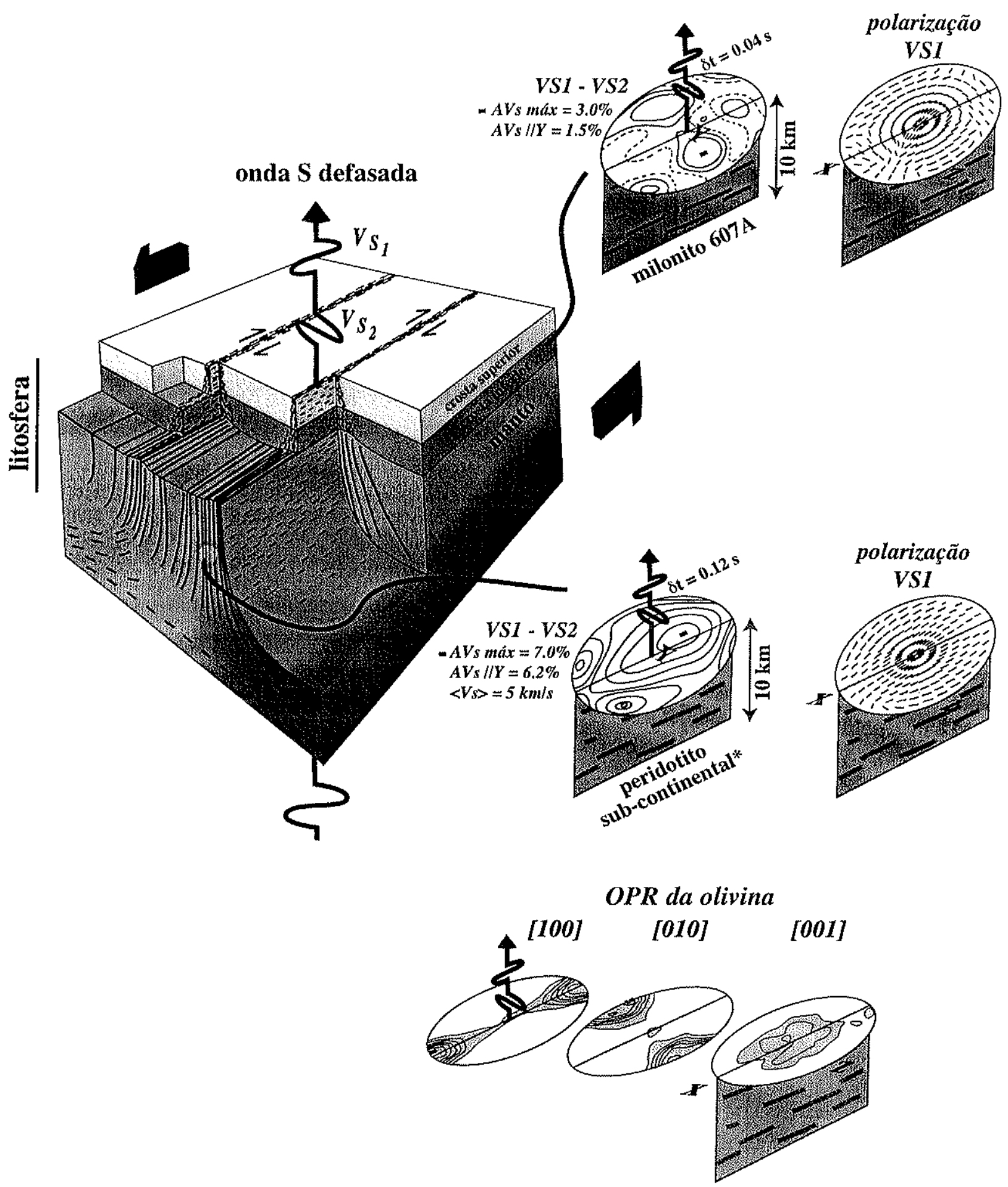

Fig. 6.4. Esquema que ilustra a defasagem $(\delta t)$ de uma onda de cisalhamento atravessando uma transcorrência litosférica (segundo Vauchez e Tommasi, 2002). A trama tectônica associada à falha na crosta e o manto tem a mesma orientação. Como exemplo são apresentadas as propriedades sísmicas das ondas $S$ de um peridotito sub-continental (* harzburgito do maciço de Ronda, Vauchez e Garrido, 2001), assim como as propriedades sísmicas de um milonito granulítico da região de Santo Antônio de Pádua. AVs máx = anisotropia de polarização máxima da onda $S$; AVs $/ / Y$ = anisotropia de polarização de uma onda $S$ que se propagea paralelamente ao eixo estrutural $Y$ (vertical); $\langle V s\rangle$ velocidade média das ondas $S$. 
Os planos de polarização da onda $S$ rápida dos milonitos ricos em quartzo e feldspato não se orientam de modo simples em relação aos eixos da deformação finita. Além disso, para uma onda que se propaga verticalmente em um meio estruturado por uma foliação vertical e uma lineação sub-horizontal, as direções do planos de polarização formam um ângulo alto (entre $45^{\circ}$ e $90^{\circ}$ ) em relação à foliação. Uma proporção elevada de anfibólio no milonito favorecerá uma polarização das ondas $S$ paralelas à foliação. Quando se compõem as propriedades sísmicas dos milonitos com anfibólio e dos milonitos de composição semelhante a de um granito, as direções dos planos de polarização Vs1 são de novo, totalmente desorganizadas em relação aos eixos X, Y e Z. Inversamente às rochas quartzo-feldspáticas, os peridotitos têm propriedades sísmicas caracterizadas por uma distribuição relativamente simples dos planos de polarização Vs1 paralelamente ao plano de foliação (Fig. 6.4). Estas diferenças entre a orientação do eixo rápido da anisotropia das ondas $\mathrm{S}$ para as rochas da crosta e as rochas do manto sugerem que a anisotropia baixa calculada nas cinco amostras estudadas teria um papel mais perturbador do que construtivo na anisotropia total da litosfera.

\subsection{Conclusão}

As propriedades sísmicas de cinco amostras foram calculadas a partir da composição modal, das OPR das principais fases minerais e das propriedades elásticas dos monocristais. As velocidades de propagação das ondas $\mathrm{P}$ e $\mathrm{S}$ são típicas para rochas da crosta continental profunda (p. ex., Barruol e Mainprice, 1993a; Christensen e Mooney, 1995). Quando a milonitização é muito intensa, a anisotropia sísmica é relativamente elevada : a anisotropia azimutal AVp atinge um valor de $5.8 \%$ e a anisotropia de polarização máxima AVs máx atinge um valor de 7\%. Entretanto, em todas as amostras, AVs máx ocupa uma posição intermediária entre os eixos da deformação finita. A amplitude da anisotropia sísmica é muito sensível ao número de fases minerais que compõem a rocha. Quanto mais alto for este número, menos a rocha será anisotrópica. A transformação do quartzo- $\alpha$ em quartzo- $\beta$ ocasiona um grande aumento da velocidade das ondas $\mathrm{P}$ e uma diminuição da anisotropia sísmica.

As duas amostras pobres em quartzo $(\leq 15 \%)$ apresentam coeficientes de Poisson altos $(\sigma>0.25)$. O plagioclásio gera uma distribuição complexa das velocidades de propagação das ondas $\mathrm{P}$ e da birrefringência das ondas $\mathrm{S}$ em relação aos eixos da deformação finita. Inversamente, uma alta porcentagem de anfibólio na rocha favorecerá propriedades sísmicas 
que apresentam relações simples com a foliação e a lineação e, uma alta anisotropia sísmica azimutal. As direções dos planos de polarização das ondas $S$ rápidas alinham-se paralelamente à lineação. Nas amostras em que o quartzo é abundante (<30\% em moda), o coeficiente de Poisson é mais baixo $(\sigma<0.24)$. As OPR de quartzo são fortes e controlam as propriedades sísmicas destas amostras. A velocidade da onda $\mathrm{P}$ tem uma distribuição complexa em relação aos eixos $\mathrm{X}, \mathrm{Y}$ e Z com Vp máx em posição intermediária. As direções de birrefringência elevada das ondas $S$ estão a $45^{\circ}$ dos eixos $X, Y$ e $Z$ e os planos de polarização das ondas $S$ rápidas são desorganizados em relação a esses mesmos eixos.

O cálculo da propriedades sísmicas permitiu estimar a refletividade de uma zona de cisalhamento fóssil cuja anisotropia dos minerais está relacionada a mecanismos ativos de alta temperatura durante a deformação, mas que resulta igualmente de processos pós-cinemáticos ("annealing" do quartzo, por exemplo). Os coeficientes de reflexão são calculados a partir de modelos simples para os quais a interface é horizontal e a direção de propagação das ondas, vertical. A amplitude dos coeficientes de reflexão entre os milonitos e seus protólitos nãodeformados é insuficiente para produzir intensas reflexões sísmicas. Estes resultados concordam com os estudos precedentes realizados em zonas miloníticas de alta temperatura (fácies granulito; p. ex.., Ji et al., 1997) mas contrastam com os estudos realizados em zonas miloníticas de temperatura mais baixa (fácies xistos verdes e anfibólito; p. ex., Fountain et al., 1984; Rey et al., 1994). A razão desta divergência relaciona-se à quase-ausência dos filossilicatos, particularmente a biotita, e às propriedades anisotrópicas muito contrastadas em relação aos eixos da deformação finita dos principais minerais que constituem a crosta profunda (feldspatos, quartzo, ortopiroxênio, ...). Se o desenvolvimento das OPR nos granulitos não constitui a principal fonte de refletividade, outros fatores poderiam agir, como o estabelecimento de contato durante a ativação das zonas de cisalhamento de unidades litológicas com impedâncias acústicas muito diferentes. Intrusões magmáticas poderiam favorecer o desenvolvimento de contatos muito refletivos (por exemplo, filões graníticos ao contato com unidades mais básicas).

Finalmente, o cálculo de birrefringência das ondas de cisalhamento indica que as zonas miloníticas de alta temperatura são meios anisotrópicos que geram defasagens muito fracas. Levando-se em conta as estimativas efetuadas para as amostras coletadas nas zonas de cisalhamento granulíticas da região de Santo Antônio de Pádua, a contribuição máxima da crosta na defasagem das ondas SKS de um deslizamento litosférico é avaliada a $0.05 \mathrm{~s}$ para 10 $\mathrm{km}$ de crosta. 


\section{CONCLUSÕES}

O estudo das rochas naturalmente deformadas sob condições de fácies eclogito e granulito, desenvolvido neste trabalho, baseia-se na análise das microestruturas e da identificação dos mecanismos de deformação ativos nestas condições (alta pressão e/ou alta temperatura). O fluxo das rochas gera uma orientação preferencial da forma e da rede cristalina dos minerais. Esta anisotropia cristalográfica tem como consequência uma anisotropia das propriedades físicas da rocha. $O$ estudo das relações entre os mecanismos de deformação dos minerais, as OPR e as propriedades físicas anisotrópicas das rochas fornece subsidios para uma melhor interpretação dos dados geofísicos em termos de processos tectônicos. As orientações preferenciais da rede foram medidas pela técnica de difração dos elétrons retroespalhados (EBSD). A utilização do EBSD permitiu superar os limites técnicos impostos pela platina universal e pela isotropia óptica de certos minerais, tais como a granada ou a magnetita. Além disso, permitiu medir em rotina as OPR dos minerais de baixa simetria, como o plagioclásio. Esta técnica é a única que possibilita obter rapidamente uma informação cristalográfica completa para todos os minerais.

As principais conclusões deste trabalho referem-se a diversas questões que foram levantadas:

- Quais são os minerais susceptiveis de fornecer informações sobre a deformação sofrida pelos eclogitos e os granulitos?

- Quais são os mecanismos intracristalinos ativados durante e após a deformação ?

- Quais são as modificações das propriedades físicas associadas com a deformação dos corpos eclogíticos e granulíticos?

- Quais são as características das reflexões sísmicas devidas à presença destas rochas na crosta e qual é o papel da anisotropia sobre esta refletividade?

Os eclogitos estudados são oriundos de domínios orogênicos de idade e de evolução geodinâmica diferentes (dos Alpes, de uma faixa caledoniana na Noruega, de uma faixa panafricana no Mali, e da faixa Sulu-Dabishan na China). A onfacita, um dos principais constituintes dos eclogitos, mostra estruturas típicas da deformação plástica: forte fábrica de forma, paredes de discordância e sub-grãos. Embora a diversidade dos locais de amostragem 
seja grande, as OPR da onfacita apresentam as mesmas características : o pólo dos planos (010) é sub-perpendicular à foliação e o eixo [001] é sub-paralelo à lineação. Os modelos numéricos desenvolvidos neste estudo mostraram que estas OPR poderiam resultar da ativação dominante dos sistemas de deslizamento: $1 / 2<110>\{110\},[001]\{110\}$ e [001] (100). A ativação preferencial destes sistemas está de acordo com os estudos de microscopia eletrônica (MET) já realizados sobre a onfacita naturalmente deformada (p. ex., Van Roermund e Boland, 1981; Buatier et al., 1991). Estas simulações numéricas sugerem que a ativação dos planos equivalentes $\{110\}$ induz uma orientação dos pólos do plano (010) perpendicular à foliação, embora o plano (010) não seja favorável ao deslizamento intracristalino. Este resultado é interessante pois mostra que a determinação dos sistemas de deslizamento a partir das OPR pode, às vezes, levar a conclusões erradas, particularmente quando a geometria dos planos de deslizamento é complexa.

O deslizamento sobre os planos $\{110\}$ deveria conduzir a um resultado similar para a orientação do eixo [010] do diopsídio, pois este mineral possui uma estrutura cristalográfica próxima daquela da onfacita. Além disso, os sistemas tendo como plano de deslizamento o plano $\{110\}$ são facilmente ativados no diopsídio, sob condições de média a alta temperatura (Ingrin et al., 1992; Raterron et al., 1994).

As variações da OPR da onfacita "típica" medida nos eclogitos naturalmente deformados, parecem correlacionar-se com as variações do regime de deformação. A simulação de OPR distintas, aplicando regimes de deformação diferentes, é um resultado encorajador, que sugere que a medida das OPR pode auxiliar na estimativa de certos parâmetros de deformação dos eclogitos, particularmente, a forma do elipsóide de deformação e a eventual existência de uma componente de cisalhamento. Contudo, a onfacita torna-se um mineral fundamental para decifrar os processos tectônicos ativos sob condições de alta pressão.

Ao contrário da onfacita, a granada não apresenta uma orientação preferencial de forma nítida, e as orientações cristalográficas medidas proporcionam geralmente uma distribuição quase isotrópica. No entanto, considerando a simetria cúbica e a ativação potencial de um grande número de sistemas de deslizamento (Voegele et al., 1998), este mineral deformado sob condições de P.T. favoráveis, poderia desenvolver somente baixas OPR. Assim, um melhor conhecimento das propriedades mecânicas da granada requer um estudo mais aprofundado. 
A medida das OPR da onfacita e da granada permitiu calcular os coeficientes de rigidez elástica das amostras eclogíticas e determinar as propriedades sísmicas médias representativas de uma dezena de eclogitos. As propriedades sísmicas médias são caracterizadas por uma anisotropia sísmica muito baixa : a anisotropia azimutal das ondas $\mathrm{P}$ $(\mathrm{AVp})$ e a anisotropia de polarização máxima das ondas $S$ (AVs max) são inferiores à $2 \%$. As ondas $\mathbf{P}$ são caracterizadas por: $V p_{\max }$ sub-paralelo à lineação e $V p_{\min }$ sub-perpendicular à foliação. As velocidades das ondas P e S são elevadas, 8.6 e $4.9 \mathrm{~km} / \mathrm{s}$ respectivamente. Nos eclogitos, a granada aumenta a velocidade das ondas $\mathrm{P}$ e $\mathrm{S}$ e reduz a anisotropia sísmica. A distribuição das velocidades e a intensidade da anisotropia estão geralmente de acordo com as velocidades sísmicas medidas em laboratório (por exemplo, Fountain, 1994; Kern, 1999). As diferenças entre as velocidades calculadas e as velocidades medidas poderiam estar em grande parte, relacionadas com as fases mineralógicas menores e com as micro-fraturas, as quais não foram consideradas em nossos cálculos.

A questão das reflexões sísmicas relacionadas com a presença de corpos eclogíticos na litosfera foi abordada através do cálculo das velocidades sísmicas. A determinação dos coeficientes de reflexão ressalta o fato de que os corpos de eclogito na crosta deveriam gerar reflexões sísmicas muito fortes, enquanto que os corpos de eclogito em contato com o manto superior deveriam ser dificilmente detectados pelas técnicas de sísmica de reflexão. A quaseisotropia sísmica dos eclogitos poderia ser um parâmetro distintivo, pois os peridotitos do manto superior apresentam uma grande anisotropia sísmica. Entretanto, os métodos sismológicos atuais não permitem explorar melhor este parâmetro.

Os granulitos estudados foram coletados em uma ampla zona milonítica na faixa neoproterozóica Ribeira, no sudeste do Brasil. Os marcadores estruturais e metamórficos levantados nos afloramentos da região de estudo indicam que a milonitização ocorreu sob condições de fácies granulito, através de grandes transcorrências dextrais. Por isso, a região de estudo escolhida torna-se particularmente interessante para o estudo dos mecanismos de deformação ativos em alta temperatura.

Os principais constituintes dos granulitos (quartzo, plagioclásio, feldspato-K, piroxênio e anfibólio) apresentam microestruturas oriundas de processos sin- e póscinemáticos. O quartzo é o mineral mais sensível ao "annealing": as microestruturas mostram que o quartzo sofreu um forte crescimento após o término da deformação, e que nenhuma deformação posterior significativa ocorreu. Nos milonitos, uma importante migração dos limites de grãos gera os "ribbons" de quartzo policristalinos paralelos à foliação. A este 
crescimento exagerado, associa-se uma orientação preferencial dos planos do romboedro (r) paralelos e, em menor medidas, ortogonais à foliação. Considerando o fato de que as OPR medidas não mostram uma coerência com as condições de temperatura durante o cisalhamento, é provável que, durante o "annealing", as OPR do quartzo desenvolvidas durante a deformação foram fortemente modificadas e a assinatura sin-tectônica das OPR do quartzo em grande parte foi suprimida. O plagioclásio e o ortopiroxênio são menos sensíveis que o quartzo ao efeito da difusão pós cinemática. Entretanto, as OPR do plagioclásio nem sempre apresentam uma distribuição simples em relação aos eixos da deformação finita. Esta relativa complexidade das OPR do plagioclásio poderia resultar da ativação, em alta temperatura, de um número elevado de sistemas de deslizamento. As OPR do ortopiroxênio e do anfibólio são coerentes com os eixos da deformação e, sugerem que a deformação ocorreu por fluxo de discordâncias com a ativação dominante do sistema de deslizamento (100) [001].

Nos granulitos miloníticos, os minerais, tais como os óxidos da solução sólida ilmenita-hematita (ou titanohematita), dominados pela ilmenita, presentes em menor quantidade, registram de maneira privilegiada a deformação em alta temperatura. Os grãos de ilmenita são fortemente alongados paralelamente à foliação e sua OPR revela-se particularmente nítida, caracterizada por uma orientação preferencial dos eixos-c subperpendiculares à foliação e os pólos dos planos prismáticos sub-paralelos à lineação. Esta OPR é interpretada como decorrente de uma deformação plástica por deslizamento basal. Exceto para uma amostra, uma obliquidade entre as OPR e os eixos da deformação finita sugere um sentido de cisalhamento dextral de acordo com os indicadores cinemáticos.

O estudo das relações entre a trama magnética (ASM) e as OPR das titanohematitas foi realizado sobre cinco milonitos. Nestas amostras, as titanohematitas representam mais de $1.5 \%$ do conteúdo modal e os estudos magnéticos revelam que os minerais paramagnéticos (ilmenita, ortopiroxênio, anfibólio e biotita) e os minerais ferromagnéticos (magnetita e titanohematitas pobres em Ti) contribuem para a ASM. Observa-se uma boa correlacão entre os eixos do elipsóide de ASM e a OPR das titanohematitas : o eixo de susceptibilidade mínima $\left(\mathrm{K}_{\min }\right)$ é perto do máximo de concentração dos eixos-c, e o eixo de susceptibilidade máxima $\left(\mathrm{K}_{\max }\right)$ esta próximo do máximo de concentração dos pólos dos planos prismáticos. Estas relações entre os eixos da ASM e as OPR das titanohematitas reforçam o significado tectônico das fábricas magnéticas. Nos granulitos, em particular nos não-milonitícos, é frequientemente impossível medir a trama tectônica. As medidas de ASM permitem uma cartografia da foliação e da lineação magnética rápida e segura. As OPR das titanohematitas poderiam fornecer um valioso apoio para a interpretação tectônica das medidas de ASM. 
O último capítulo deste manuscrito aborda a questão do papel da milonitização na refletividade das zonas de cisalhamento de alta temperatura e a contribuição da crosta terrestre à defasagem das ondas $\mathrm{S}$ nos domínios de transcorrências litosféricas.

O quartzo e o plagioclásio são os dois principais constituintes das amostras estudadas. As propriedades sísmicas dos "ribbons" de quartzo nos milonitos mostram uma distribuição complexa em relação aos eixos da deformação finita. Nas amostras onde o quartzo domina, a anisotropia azimutal das ondas $\mathrm{P}$ e a anisotropia de polarização máxima das ondas $\mathrm{S}$ podem ser elevadas (até 5\% para AVp e 7\% para AVs max). Entretanto, as direções de forte birefringência das ondas $S$ situam-se à $45^{\circ}$ dos eixos $\mathrm{X}, \mathrm{Y}, \mathrm{Z}$ e os planos de polarização das ondas $S$ rápidas são relativamente desorganizados em relação a estes mesmos eixos. Os milonitos ricos em quartzo são caracterizados por um coeficiente de Poisson relativamente baixo $(\sigma<0.24)$. O plagioclásio gera também uma distribuição complexa das velocidades de propagação das ondas $\mathrm{P}$ e da birrefringência das ondas $\mathrm{S}$ em relação aos eixos da deformação finita. As amostras para as quais o plagioclásio é o principal constituinte mineralógico possui um coeficiente de Poisson mais alto $(\sigma>0.24)$. Uma porcentagem alta de anfibólio ou de ortopiroxênio na rocha favorece as propriedades sísmicas que apresentam relações simples em relação à foliação e à lineação.

O cálculo das propriedades sísmicas dos milonitos permitiu estimar a refletividade de uma zona de cisalhamento de alta temperatura. A amplitude dos coeficientes de reflexão entre os milonitos e seus protólitos não deformados é muito baixa e aparece insuficiente para produzir fortes reflexões sísmicas. Estes resultados contrastam com os estudos realizados sobre as zonas de cisalhamento de mais baixa temperatura, nas quais os milonitos são ricos em filossilicatos e constituem refletores sísmicos de qualidade (p. ex., Rey et al. 1994; Fountain et al. 1984). Estes resultados sugerem que na base da crosta terrestre, zonas de cisalhamento desenvolvidas sob condições progradantes poderiam ficar invisíveis às técnicas de sísmica reflexão.

Finalmente, a determinação da birrefringência das ondas de cisalhamento mostra que as zonas miloníticas de alto grau são meios anisotrópicos produzindo defasagens muito baixas. A contribuição dos milonitos granulíticos em uma transcorrência é avaliada em $0.05 \mathrm{~s}$ para uma espessura de $10 \mathrm{~km}$.

A técnica do EBSD torna possível um estudo sistemático das microestruturas e das orientações cristalográficas de rochas polifásicas e as evoluções dos materiais e da 
informática já estão abrindo caminho para estudos mais aprofundados. Por exemplo, é cada vez mais difícil associar no MEV a imagem em contraste de orientação com a medida das orientações cristalográficas. Além disso, a evolução dos "softwares" de tratamento de dados permite estabelecer uma cartografia cristalográfica detalhada cada vez mais rápida de uma amostra.

Os problemas salientados para a interpretação das OPR da onfacita nos eclogitos e dos "ribbons" de quartzo mostram que, hoje em dia, a medida das orientações cristalográficas de alguns eixos cristalográficos particulares torna-se insuficiente. Uma boa compreensão dos mecanismos de deformação nas rochas decorre de métodos complementares associando a aquisição da informação cristalográfica completa e a modelagem para o desenvolvimento das OPR, o estudo experimental da reologia dos minerais e a observação, através da microscopia eletrônica de transmissão, das estruturas e dos defeitos intracristalinos. 


\section{REFERÊNCIAS}

BIBLIOGRÁFICAS 


\section{REFERÊNCIAS BIBLIOGRÁFICAS}

Abalos, B., 1997. Omphacite fabric variation in the Cabo Ortegal eclogite (NW Spain): relationship with strain symmetry during high-pressure deformation. Journal of Structural Geology, 19: 621-637.

Adams, B.I., Wright, S.I., Kunze, K., 1993. Orientation imaging: the emergence of a new microscopy. Metallurgical Transactions, 24A: 819-83i.

Agar, S.M., Lloyd, G.E., 1997. Deformation of Fe-Ti oxides in gabbroic shear zones from the Mark area. Proceedings of the Ocean Drilling Programs, Scientific Results, 153: 123-140.

Aleksandrov, K.S., Alchikov, U.V., Belikov, B.P., Zaslavskii, B.I., Krupnyi, A.I., 1974. Velocities of elastic waves in minerals at atmospheric pressure and increasing precision of elastic constants by means of EVM (in Russian). Izv. Acad. Sci. USSR, Geol. Ser., 10: 15-24.

Aleksandrov, K.S., Ryzhova, T.V., 1961. The elastic properties of rock forming minerals II: Layered silicates. Izv. Acad. Sci. USSR, Geophys.Phys. Solid Earth, 1165-1168.

Almeida, F.F.M., Amaral, G., Cordani, U.G., Kawashita, K., 1973. The Precambrian evolution of the South America Cratonic Margin South of the Amazon River. In: Nairn, A.E.M., Stehli, F.G. (Eds.), Ocean basins and margins. New York: Plenum Press, $1411-446 \mathrm{pp}$.

Almeida, F.F.M., Hasui, Y., Carneiro, C., 1975. O lineamento de Além-Paraíba. Anais da Academia Brasileira de Ciências, 46: 575.

Almeida, J.C.H., 2000. Zonas de cisalhamento dúctil de alto grau do Médio Vale do Rio Paraíba do Sul. Tese de Doutorado: UNESP, Rio Claro (SP), Brasil, 190 p.

Altenberger, U., 1992. Stress-induced Natural Transformation of Orto- to Clinohypersthene in Metagabbros of the Ivrea Zone, Northern Italy. Mineralogy and Petrology, 46: 43-48.

Andersen, T.B., 1998. Extensional tectonics in the Caledonides of southern Norway, an overview. Tectonophysics, 285: 333-351.

Anderson, D.L., 1989. Theory of the Earth. Oxford: Blackwell Scientific Publications, 366 p.

Ando, J.I., Fujino, K., Takeshita, T., 1993. Dislocation microstructures in naturally deformed garnets. Physics of the Earth and Planetary Interiors, 80: 105-116.

Ansel, V., Nataf, H.C., 1989. Anisotropy beneath 9 stations of the Geoscope broadband network as deduced from shear-wave splitting. Geophysical Research Letters, 16: 409-412.

Archanjo, C.J., 1993. Fabriques de plutons granitiques et la déformation crustale du nord-est du Brésil. Une étude par anisotropie de susceptibilité magnétiques de granites ferromagnétiques. Doctorat: Université Toulouse III, Toulouse, France, 165 p.

Archanjo, C.J., Launeau, P., Bouchez, J.L., 1995. Magnetic fabric vs. magnetite and biotite shape fabrics of the magnetite-bearing granite pluton of Gameleiras (Northeast Brazil). Physics of the Earth and Planetary Interiors, 89: 63-75.

Ashby, M.F., Verral, R.A., 1973. Diffusion accomodated flow and superplasticity. Acta Metallurgica, 21: 149163.

Assumpção, M., James, D., Snoke, A., 2002. Crustal thicknesses in SE Brasilian Shield by receiver function analysis: Implications for isostatic compensation. Journal of Geophysical Research, 107: (2)1-(2)14.

Austrheim, H., 1987. Eclogitization of the lower crustal granulites by fluid migration through shear zones. Earth and Planetary Science Letters, 81: 221-232.

Austrheim, H., 1991. Eclogite formation and dynamics of crustal roots under continental collision zones. Terra Nova, 3: 492-499.

Austrheim, H., Griffin, W.L., 1985. Shear deformation and eclogite formation within granulite facies anorthosites of the Bergen Arcs, western Norway. Chemical Geology, 50: 267-281.

Avé Lallemant, H.G., 1978. Experimental deformation of diopside and websterite. Tectonophysics, 48: 1-27. 
Babuska, V., 1972. Elasticity and anisotropy of dunite and bronzitite. Journal of Geophysical Research, 77: 6955-6965.

Babuska, V., Fiala, J., Kumazawa, M., Ohno, I., 1978. Elastic properties of garnet solid-solution series. Physics of the Earth and Planetary Interiors, 16: 157-176.

Barruol, G., Mainprice, D., 1993a. 3D seismic velocities calculated from LPOs and reflectivity of a lower crustal section - Example of the Val Sesia (Ivrea Zone, Northern Italy). Geophysical Journal International, 115: $1169-1188$.

Barruol, G., Mainprice, D., 1993b. A quantitative evaluation of the contribution of crustal rocks to the shear wave splitting of teleseismic SKS waves. Physics of the Earth and Planetary Interiors, 78: 281-300.

Barruol, G., Mainprice, D., Kern, H., Saint Blanquat, M., Compte, P., 1992. 3D seismic study of a ductile shear zone from laboratory and petrofabric data (Saint Barthélémy Massif, Northern Pyrénées, France). Terra Nova, 4: 63-76.

Barruol, G., Silver, P.G., Vauchez, A., 1997. Seismic anisotropy in the eastern US: deep structure of a complex continental plate. Journal of Geophysical Research, 102: 8329-8348.

Bascou, J., Barruol, G., Vauchez, A., Mainprice, D., Egydio-Silva, M., 2001. EBSD-measured lattice preferred orientations and seismic properties of eclogites. Tectonophysics, 342: 61-80.

Bascou, J., Raposo, M.I.B., Vauchez, A., Egydio-Silva, M., 2002a. Titanohematite lattice preferred orientation and magnetic anisotropy in high-temperature mylonites. Earth and Planetary Science Letters, 198: 77-92.

Bascou, J., Tommasi, A., Mainprice, D., 2002b. Plastic deformation and development of clinopyroxene lattice preferred orientations in eclogites. Journal of Structural Geology, 24: 1357-1368.

Bass, J.D., Weidner, D.J., 1984. Elasticity of single-crystal orthoferrosilite. Journal of Geophysical Research, 89: $4359-4371$.

Ben Ismaîl, W., Mainprice, D., 1998. An olivine fabric database: An overview of upper mantle fabrics and seismic anisotropy. Tectonophysics, 296: 145 157.

Benn, K., Rochette, P., Bouchez, J.L., Hattori, K., 1993. Magnetic susceptibility, magnetic mineralogy and magnetic fabrics in a late Archean granitoid-gneiss belt. Precambrian Research, 63: 59 81.

Bhagat, S.S., Bass, J.D., Smyth, J.R., 1992. Single-crystal elastic properties of omphacite-C2/c by Brillouin spectroscopy. Journal of Geophysical Research, 97: 6843-6848.

Biermann, C., 1981. (100) deformation twins in naturally deformed amphiboles. Nature, 292: 821-823.

Birch, F, 1961. The velocity of compressional waves in rocks to $10 \mathrm{kbar}$, Part 2. Journal of Geophysical Research, 66: 2199-2224.

Blacic, J.D., 1975. Plastic-deformation mechanisms in quartz: the effect of water. Tectonophysics, 27: $271-294$.

Blumenfeld, P., Bouchez, J.L., 1988. Shear criteria in granite and migmatite deformed in the magmatic and solid states. Journal of Structural Geology, 10: 361-372.

Blundy, J.D.B., Holland, T.J.B., 1990. Calcic amphibole equilibria and a new amphibole - plagioclase geothermometer. Contributions to Mineralogy and Petrology, 104: 208-224.

Boland, J.N., Tullis, T.E., 1986. Deformation behavior of wet and dry clinopyroxenite in the brittle to ductile transition region. In: Hobbs, B.E., Heard, H.C. (Eds.), Mineral and Rock Deformation: Laboratory Studies. Washington, D.C.: American Geophysical Union, Geophysical Monograph 3635.49 pp.

Bons, P.D., Urai, J.L., 1992. Syndeformational grain growth/ microstructures and kinetics. Journal of Structural Geology, 15: 403-411.

Borradaile, G.J., 1988. Magnetic susceptibility, petrofabric and strain. Tectonophysics, 156: 1-20.

Borradaile, G.J., Henry, B., 1997. Tectonic applications of magnetic susceptibility and its anisotropy. Earth Science Reviews, 42: 49.93.

Borradaile, G.J., Werner, T., Lagroix, F., 1999. Magnetic fabrics and anisotropy-controlled thrusting in the Kapusksing Structural Zone, Canada. Tectonophysics, 325: 207-225. 
Bouchez, J.L., 1997. Granite is never isotropic: an introduction to AMS studies of granitic rocks. In: Bouchez, J.L., Hutton, D.H.W., Stephens, W.E. (Eds.), Granite : from segregation of melt to emplacement fabrics. Rotterdam: Kluwer Academic, 95-112 pp.

Bouchez, J.L., Dervin, P., Mardon, J.P., Englander, M., 1979. La diffraction neutronique appliquée à l'étude de l'orientation préférentielle de réseau dans les quartzites. Bulletin de Minéralogie, 102: 225-231.

Bouchez, J.L., Duval, P., 1982. The fabric of polycrystalline ice deformed in simple shear: experiments in torsion, natural deformation and geometrical interpretation. Journal of Textures and Microstructures, 5: 1-17.

Bouchez, J.L., Nicolas, A., Lister, G., 1983. Fabric asymmetry and shear sense in movement zones. Geologisches Rundschau, 72: 401-419.

Boullier, A.M., Bouchez, J.-L., 1978. Le quartz en rubans dans les mylonites. Bulletin de la Société géologique de France, 7: 253-262.

Boullier, A.M., Gueguen, Y., 1975. S-P mylonites. Origin of some mylonites by superplastic flow. Contributions to Mineralogy and Petrology, 50: 121-134.

Boundy, T.M., Fountain, D.M., Austrheim, H., 1992. Structural development and petrofabrics of eclogite facies shear zones, Bergen Arcs, western Norway: Implications for deep crustal deformational processes. Journal of Metamorphic Geology, 10: 127-146.

Brenner, T.L., Ferrari, A.L., Penha, H.M., 1980. Lineamentos estruturais do nordeste do Estado do Rio de Janeiro. In: $31^{\circ}$ Congresso Brasileiro de Geologia. Baneário de Camboriú, Brasil 5 2551-2564.

Bretheau, T., Castaing, J., Rabier, J., Veyssière, P., 1979. Mouvement des dislocations et plasticité à haute température des oxydes binaires et ternaires. Advances in Physics, 28: 829-1014.

Brey, G.P., Kohler, T., 1990. Geothermobarometry in four-phase lherzolite; II, New thermobarometers, and pracical assessment of existing thermobarometers. Journal of Petrology, 31: 1353-1378.

Brokmeier, H.G., 1989. Neutron diffraction texture analysis of multi-phase systems. Textures and Microstructures, 10: 325-345.

Brueckner, H.K., Cunningham, D., Alkmin, F.F., Marshak, S., 2000. Tectonic implications of Precambrian SmNd dates from the southern São Francisco craton and adjacent Araçuaí and Ribeira belts, Brazil. Precambrian Research, 99: 255-269.

Buatier, M., Van Roermund, H.L.M., Drury, M.R., Lardeaux, J.M., 1991. Deformation and recrystallization mechanisms in naturally deformed omphacites from the Sesia-Lanzo zone; geophysical consequences. Tectonophysics, 195: 11-27.

Bunge, H.J., 1982. Texture Analysis in Materials Sciences. London: Butterworths, 593 p.

Bunge, H.J., 1985. Representation of preferred orientations. In: Wenk, H.-R. (Ed.), Preferred orientation in deformed metals and rocks: an introduction to modern texture analysis. New York: Academic press, 78$108 \mathrm{pp}$.

Butler, R.W.H., 1986. Thrust tectonics, deep structure and crustal subduction in the Alps and Himalayas. Journal of the Geological Society of London, 143: 857-873.

Bystricky, M., Mackwell, S., 2001. Creep of clinopyroxenes aggregates. Journal of Geophysical Research, 106: 13443-13454.

Caby, R., 1994. Precambrian coesite from northern Mali: first record and implications for plate tectonics in the trans-Saharan segment of the Pan-African belt. European Journal of Mineralogy, 6: 235-244.

Caby, R., Kienast, J.R., Saliot, P., 1978. Structure, métamorphisme et modèle d'évolution tectonique des Alpes occidentales. Rev. Géogr. Phys. Géol. Dyn., 20: 307-322.

Campanha, G.A.C., 1981. O lineamento de Além-Paraíba na área de Três Rios (RJ). Revista Brasileira de Geociências, 11: 159-171.

Campos Neto, M.C., Figueiredo, M.C.H., 1995. The Rio Doce orogeny, Southeastern Brazil. Journal of South American Earth Sciences, 8: 143-162.

Canova, G.R., Wenk, H.R., Molinari, A., 1992. Deformation modelling of multi-phase polycrystals: Case of a quartz-mica aggregate. Acta metallurgica materialia, 40: 1519-1530. 
Castelnau, O., Duval, P., Lebensohn, R.A., Canova, G.R., 1996. Viscoplastic modeling of texture development in polycrystalline ice with a self-consistent approach: Comparison with bound estimates. Journal of Geophysical Research, 101: 13851-13868.

Chai, M., Michael Brown, J., 1997. The elastic constants of a pyrope-grossular-almandine garnet to 20 Gpa. Geophysical Research Letters, 24: 523-526.

Chastel, Y.B., Dawson, P.R., Wenk, H.-R., Bennet, K., 1993. Anisotropic convection with implications for the upper mantle. Journal of Geophysical Research, 98: 17757-17771.

Christensen, N.I., 1974. Compressional wave velocities in possible mantle rocks to pressure of 30 kilobars. Journal of Geophysical Research, 79: 407-412.

Christensen, N.I., 1989. Reflectivity and seismic properties of the deep continental crust. Journal of Geophysical Research, 94: 17793-17804.

Christensen, N.I., 1996. Poisson's ratio and crustal seismology. Journal of Geophysical Research, 101: 3139. 3156.

Christensen, N.I., Mooney, W.D., 1995. Seismic velocity structure and composition of the continental crust: a global review. Journal of Geophysical Research, 100: 9761-9788.

Christensen, N.I., Szymanski, D.L., 1988. Origin of reflections from the Brevard fault zone. Journal of Geophysical Research, 93: 1087-1102.

Christie, J.M., Ardell, A.J., 1974. Substructures of deformation lamellae in quartz. Geology, 2: 405-408.

Christoffersen, R., Kronenberg, A.K., 1993. Dislocation interactions in experimentally deformed biotite. Journal of Structural Geology, 15: 1077-1095.

Clark, J.R., Appleman, D.E., Papike, J.J., 1969. Crystal-chemical characterization of clinopyroxenes based on eight new structure refinements. Mineral. Soc. Amer. Spec. Pap., 2: 31-50.

Coe, R.S., Kirby, S.H., 1975. The orthoenstatite to clinoenstatite transformation by shearing and reversion by annealing: mechanism and potential applications. Contributions to Mineralogy and Petrology, 52: 29-55.

Collins, M.D., Brown, J.M., 1998. Elasticity of an upper mantle clinopyroxene. Physics and Chemistry of Minerals, 26: 7-13.

Compagnoni, R., Dal Piaz, G.Y., Hunziker, J.C., Gosso, G., Lombardo, B., Williams, P.F., 1977. The SesiaLanzo zone: a slice of continental crust with alpine high pressure-low temperature assemblage in the Western Italien Alps. Rend. Soc. Ital. Mineral. Petrol., 33: 281-334.

Constable, C., Tauxe, L., 1990. The bootstrap for magnetic susceptibility tensor. Journal of Geophysical Research, 95: 8383-8395.

Corrêa Neto, A.V., Dayan, H., 1994. Justaposição tectônica de níveis crustais distintos em faixas transpressivas: o caso da zona de cisalhamento do Rio Paraíba do Sul (RJ). In: $38^{\circ}$ Congresso Brasileiro de Geologia. Balneário Camboriú, Brasil 1 249-250.

Corrêa Neto, A.V., Dayan, H., Valença, J.G., Cabral, R., 1993. Geologia e estrutura da zona de cisaillemento do rio Paraíba do Sul no Trecho entre Três Rios e Sapucaia (RJ). In: $38^{\circ}$ Congresso Brasileiro de Geologia. Balneário Camboriú, Brasil 1 160-161.

Crosson, R.S., Lin, J.W., 1971. Voigt and Reuss prediction of anisotropic elasticity of dunite. Journal of Geophysical Research, 76: 570 578.

Cumbest, R.J., Van Roermund, H.L.M., Drury, M.R., Simpson, C., 1989. Burgers vector determination in clinoamphibole by computer simulation. American Mineralogist, 74: 586-592.

Cuthbert, S.J., Carswell, D.A., 1990. Formation and exhumation of medium-temperature eclogites in the Scandinavian Caledonides. In: Carswell, D.A. (Ed.), Eclogite facies rocks. Glasgow and London: Blackie, $181-203 \mathrm{pp}$.

Dal Piaz, G.V., 1974. Le métamorphisme de haute pression et basse température dans l'évolution structurale du bassin ophiolitique alpino-apenninique. Schweizerische Mineralogische und Petrographische Mitteilungen, 54: 399-424. 
Dayan, H., Keller, J.V.A., 1990. A zona de cisalhamento do Rio Paraíba do Sul nas vizinhanças de Três Rio (RJ): uma análise da deformação dada por algumas feições estruturais. Revista Brasileira de Geociências, 19: 494-506.

Deer, W.A., Howie, R.A., Zussman, J., 1966. An introduction to rock forming minerals. Hong Kong: Longman, $695 \mathrm{p}$.

Dell'Angelo, L.N., Tullis, J., 1989. Fabric development in experimentally sheared quartzites. Tectonophysics, 169: $1-21$.

Diaconescu, C., Knapp, J.H., Brown, L.D., Steer, D.N., 1997. Moho faults. In: American Geophysical Union Fall meeting. San Francisco EOS, Transactions 78 F724.

Dingley, D.J., Field, D.P., 1997. Electron backscatter diffraction and orientation imaging microscopy. Materials Science and Technology, 13: 69-78.

Dunlop, D.J., Özdemir, Ö., 1997. Rock Magnetism: Fundamentals and Frontiers. Cambridge: Cambridge Univ. Press, 573 p.

Ebert, H.D., Hasui, Y., 1998. Transpression tectonics and strain partitioning during oblique collision between three plates in the Precambrian of south-east Brazil. In: Holdsworth, R.E., Strachan, R.A., Dewey, J.F. (Eds.), Continental Transpressional and Transtensional Tectonics. London: Geological Society, Special Publications, $135231-252 \mathrm{pp}$.

Egydio-Silva, M., Mainprice, D., 1999. Determination of stress directions from plagioclase fabrics in high grade deformed rocks (Além Paraiba shear zone, Ribeira fold belt, southeastern Brazil). Journal of Structural Geology, 21: 1751-1771.

Egydio-Silva, M., Vauchez, A., Bascou, J., Hippertt, J., 2002. High temperature deformation in the Neoproterozoic transpressional Ribeira belt, southeast Brazil. Tectonophysics, 352: 203-224.

Engels, J.P., 1972. The catazonal poly-metamorphic rocks of Cabo Ortegal (NW Spain), a structural and petrographic study. Leidse Geologische Medelingen, 48: 83-133.

Ernst, W.G., 1977. Mineralogic study of eclogitic rocks from Alpe Arami, Lepontine Alps, southern Switzerland. Journal of Petrology, 18: 371-398.

Eshelby, J.D., 1957. The determination of the elastic field of an ellipsoidal inclusion, and related problems. Proceedings of the Royal Society of London, A, 241: 376-396.

Etchecopar, A., Vasseur, G., 1987. A 3-D kinematic model of fabric development in polycrystalline aggregates: comparison with experimental and natural examples. Journal of Structural Geology, 9: 705-717.

Faure, M., Lin, W., Le Breton, N., 2001. Where is the North China-South China block boundary in eastern China? Geology, 29: 119-122.

Ferry, J.M., Spear, F., 1978. Experimental calibration of the partitioning of Fe and $\mathrm{Mg}$ between biotite and garnet. Contributions to Mineralogy and Petrology, 71: 13-22.

Figueiredo, M.C.H., Campos Netos, M.C., 1993. Geochemistry of the Rio Doce magmatic arc, Southern Brasil. Anais da Academia Brasileira de Ciências, 65: 63-81.

Figueiredo, M.C.H., Teixeira, W., 1996. The Mantiqueira Metamorphic Complex, Eastern Minas Gerais State: Preliminary Geochrological and Geochemical Results. Anais da Academia Brasileira de Ciências, 68: 223-246.

Fountain, D.M., Boundy, T.M., Austrheim, H., Rey, P., 1994. Eclogite-facies shear zones-deep crustal reflectors? Tectonophysics, 232: $411-424$.

Fountain, D.M., Hurich, C.A., Smithson, S.B., 1984. Seismic reflectivity of mylonite zones in the crust. Geology, 12: 195-198.

Fountain, D.M., Salisbury, M.H., 1981. Exposed cross-sections through the continental crust: implication for crustal structure, petrology and evolution. Earth and Planetary Science Letters, 56: 263 277.

Fueten, F., Robin, P.-Y.F., Stephens, R., 1991. A model for the development of a domainal quartz c-axis fabric in a coarse-grained gneiss. Journal of Structural Geology, 13: 1111-1124.

Furlong, K.P., Fountain, D.M., 1986. Continental crust underplatting: Thermal considerations and seismicpetrologic consequences. Joumal of Geophysical Research, 91: 8285-8294. 
Fynn, G.W., Powell, W.J.A., 1979. The cutting and polishing of electro-optic materials. London: Adams Hilger, $216 \mathrm{p}$.

Gandais, M., Willaime, C., 1984. Mechanical properties of feldspars. In: Brown, W.L. (Ed.), Feldspars and Feldspathoids. Dordrecht: C137 207-246 pp.

Gleason, G., Tullis, J., 1990. The effect of annealing on the lattice preferred orientations of deformed quartz aggregates. In: AGU 71657.

Godard, G., Van Roermund, H.L.M., 1995. Deformation-induced clinopyroxene from eclogites. Journal of Structural Geology, 17: 1425-1443.

Green, H.W., 1967. Quartz: extreme preferred orientation produce by annealing. science, 157: 1444-1447.

Grégoire, V., Darrozes, J., Gaillot, P., Nédélec, A., Launeau, P., 1998. Magnetite grain shape fabric and distribution anisotropy vs rock magnetic fabric: a three-dimensional case study. Journal of Structural Geology, 20: 937-944.

Griffin, W.L., O'Reilly, S.Y., 1987. Is the continental Moho the crust-mantle boundary? Geology, 15: 241-244.

Griggs, D.T., Turner, F.J., Heard, H.C., 1960 . Deformation of rocks at $500^{\circ}$ to $800^{\circ} \mathrm{C}$. In: Griggs, D.T., Handin, J.W. (Eds.), Rock deformation. Geol. Soc. Am. Mem., 79 39-104 pp.

Grolier, J., Fernandez, A., Hucher, M., Riss, J., 1991. Les propriétés physiques des roches-Théories et modeles. Paris: Masson, 462 p.

Halliday, A.N., Dickin, A.P., Hunter, R.N., Davies, G.R., Dempster, T.J., Hamilton, P.J., Upton, B.G.J., 1993. Formation and composition of the lower continental crust: evidence from scottish xenolith suites. Journal of Geophysical Research, 98: 581-607.

Halls, H.C., Hanes, J.A., 1999. Paleomagnetism, anisotropy of magnetic susceptibility, and argon-argon geochronology of the Clearwater Anorthosite, Saskatchewan, Canada. Tectonophysics, 312: 235-248.

Haralyi, N., Hasui, Y., 1982. The gravimetric information and the Archean-Proterozoic structural framework of Eastern Brazil. Revista Brasileira de Geociências, 12: 160-166.

Harley, S.L., green, D.H., 1982. Garnet-orthopyroxene barometry for granulites and peridotites. Nature, 300: 697-700.

Hasui, Y., Carneiro, C.D.R., Coimbra, A.M., 1975. The Ribeira folded belt. Revista Brasileira de Geociências, 5: $257-266$.

Heilbron, M., 1993. Evolução tectono-metamórfica da seção Bom jardim de Minas (MG) - Barra do Piraí (RJ). Setor central da Faixa Ribeira. Tese de Doutoramento: USP, São Paulo, Brasil, 268 p.

Heilbron, M., Valeriano, C.M., Almeida, J.C.H., 1991. A Megassinforma do Paraíba do Sul e sua implicação na compartimentação tectônica do setor central da Faixa Ribeira. In: Simpósio de Geologia do Sudeste. São Paulo, Brasil 519-527.

Heilbron, M., Valeriano, C.M., Valladares, C.S., Machado, N., 1995. A orogênese Brasiliana no segmento central da Faixa Ribeira, Brasil. Revista Brasileira de Geociências, 25: 249-266.

Heilbronner, R., Tullis, J., 2001. Effect of static annealing on microstructures and CPO of quartzites deformed in axial compression and shear. In: Deformation Mechanisms, Rheology and Tectonics. Noordwijkerhout, Netherlands Universiteit Utrecht 68.

Heinrich, C.A., 1986. Eclogite facies regional metamorphism of hydrous mafic rocks in the Central Alpine Adula Nappe. Journal of Petrology, 27: 123-154.

Heintz, M., Debayle, E., Vauchez, A., Assumpção, M., 2000. A 3D shear velocity model for the upper mantle of South America. In: AGU. São Francisco 81 F832.

Heintz, M., Vauchez, A., Assumpção, M., Barruol, G., 2002. Panafrican Upper Mantle flow evidenced by Seismic Anisotropy in SE Brazil. Earth and Planetary Science Letters, submitted.

Helmstaedt, H., Anderson, O.L., Gavasci, A.T., 1972. Petrofabric studies of eclogite, spinel-websterite, and spinel-lherzolite xenoliths from kimberlite-bearing breccia pipes in southeastern Utah and northeastern Arizona. Journal of Geophysical Research, 77: 4350-4365.

Henning-Michaeli, C., 1977. Microscopic structure studies of experimentally and naturally deformed hematite ores, Tectonophysics, 39: 255-271. 
Herquel, G., Tapponnier, P., Wittlinger, G., Mei, J., Shi, D., 1999. Teleseismic shear wave splitting and lithospheric anisotropy beneath and across the Altyn Tagh fault. Geophysical Research Letters, 26: 32253228 .

Herquel, G., Wittlinger, G., Guilbert, J., 1995. Anisotropy and crustal thickness of northern-Tibet: New constraints for tectonic models. Geophysical Research Letters, 22: 1925-1928.

Hill, R., 1965. A self-consistent mechanics of composite materials. Journal of the Mechanics and Physics of Solids, 13: 213-222.

Hippertt, J., Rocha, A., Lana, C., Egydio-Silva, M., Takeshita, T., 2001. Quartz plastic segregation and ribbon development in high grade striped gneisses. Journal of Structural Geology, 23: 67-80.

Hobbs, B.E., Means, W.D., Williams, P.F., 1976. An outline of structural geology. New York: Wiley, 571 p.

Hodges, K.V., Spear, F., 1982. Geothermometry, geobarometry and the Al2SiO5 triple point at Mt. moosilauke, New Hampshire. American Mineralogist, 67: 118-1134,

Hough, P.V.C., 1962. A method and means for recognizing complex patterns. U.S. Patent 3069654.

Hrouda, F., 1982. Magnetic anisotropy of rocks and its application in geology and geophysics. Geophysical Surveys, 5: 37-82.

Hrouda, F., Siemes, H., Herres, N., Hennig-Michaeli, C., 1985. The relationship between the magnetic anisotropy and the c-axis fabric in a massive hematite ore. Journal of Geophysics, 56: 174-182.

Hunziker, J.C., 1974. Rb-Sr and K-Ar age determination and alpine tectonic history of the western Alps. Mem. Ist. Geol. Min. Univ. Padov, 31: 1-55.

Ildefonse, B., Lardeaux, J.M., Caron, J.M., 1990. The behavior of shape preferred orientations in metamorphic rocks: amphiboles and jadeites from the Monte Mucrone area (Sesia-Lanzo zone, Italian Western Alps). Journal of Structural Geology, 12: 1005-1011.

Ingrin, J., Doukhan, N., Doukhan, J.C., 1991. High-temperature deformation of diopside single crystals. 2, TEM investigation of the induced defect microstructures. Journal of Geophysical Research, 96: 1428-14297.

Ingrin, J., Doukhan, N., Doukhan, J.C., 1992. Dislocation glide systems in diopside single crystals deformed at 800-900 ${ }^{\circ}$ C. European Journal of Mineralogy, 4: 1291-1302.

Jacobsohn, T.M., 2002. Aplicação da anisotropia de susceptibilidade magnetica na analise cinematica em rochas metamorficas de alto grau - Complexos Juiz de Fora e Paraíba do Sul - Divisa MG/RJ. Tese de Mestrado: USP, São Paulo, Brasil, 121 p.

Jackson, M., 1991. Anisotropy of magnetic remanence: a brief review of mineralogical sources, physical origins and geological applications, and comparison with susceptibility anisotropy. Pure and Applied Geophysics, 136: 1-28.

Jahn, B.M., Caby, R., Monié, P., 2001. The oldest UHP eclogites of the world: age of UHP metamorphism, nature of protoliths and tectonic implications. Chemical Geology, 178: 143 158.

Jamtveit, B., Bucher-Nurminen, K., Austrheim, H., 1990. Fluid controlled eclogitization of granulites in deep crustal shear zones, Bergen Arcs, western Norway. Contributions to Mineralogy and Petrology, 104: 184-193.

Jelinek, V., 1981. Characterization of the magnetic fabrics of rocks. Tectonophysics, 79: 63-67.

Ji, S., Long, C., Martignole, J., Salisbury, M., 1997. Seismic reflectivity of a finely layered, granulite-facies ductile shear zone in the southern Grenville Province (Quebec). Tectonophysics, 279: 113-133.

Ji, S., Mainprice, D., 1988. Natural deformation fabrics of plagioclase: implications for slip systems and seismic anisotropy. Tectonophysics, 147: 145-163.

Ji, S., Mainprice, D., 1990. Recrystallization and fabric development in plagioclase. Journal of Geology, 98: 6579.

Ji, S., Salisbury, M., Hanmer, S., 1993. Petrofabric, P-wave anisotropy and seismic reflectivity of high-grade tectonites. Tectonophysics, 222: 195-226.

Ji, S., Zhao, X., Zhao, P., 1994. On the measurements of plagioclase lattice preferred orientations. Journal of Structural Geology, 16: 1711-1718. 
Joesten, R., 1983. Grain growth and grain boundary diffusion in quartz from the Christmas Mountains (Texas) contact aureole. American Journal of Science, 283-A: 233-254.

Jones, T.D., Nur, A., 1984. The nature of seismic reflections from deep crustal fault zones. Journal of Geophysical Research, 89: 3153-3171.

Kammer, E.W., Pardue, T.E., Frissel, H.F., 1948. A determination of the elastic constants for beta-quartz. Journal of Applied Physics, 19: 265-270.

Karato, S., 1988. The role of recrystallization in the preferred orientation of olivine. Physics of the Earth and Planetary Interiors, 51: 107-122.

Kern, H., 1990. Laboratory seismic measurements: an aid in the interpretation of seismic field data. Terra Nova, 2: 617-628.

Kern, H., Gao, S., Jin, Z., Popp, T., Jin, S., 1999. Petrophysical studies on rocks from the Dabie ultrahighpressure (UHP) metamorphic belt, Central China: implications for the composition and delamination of the lower crust. Tectonophysics, 301: 191-215.

Kern, H., Schenk, V., 1985. Elastic wave velocities in rocks from a lower crustal section in southern Calabria (Italy). Physics of the Earth and Planetary Interiors, 40: 147-160.

Kern, H., Wenk, H.R., 1985. Anisotropy in rocks and the geological significance. In: Wenk, H.R. (Ed.), Preferred orientation in deformed metals and rocks: an introduction to modern texture analysis.: Academic Press Inc. 537-555 pp.

Kikuchi, S., 1928. Diffraction of cathode rays by mica. Jap. J. Phys., 5: 83-96.

Krabbendam, M., Dewey, F., 1998. Exhumation of UHP rocks by transtension in the Western Gneiss Region, Scandinavian Caledonides. In: Holdsworth, R.E., Strachan, R.A., Dewey, J.F. (Eds.), Continental Transpressional and Transtensional Tectonics. London: Geological Society of London, Special Publications, $135159-181 \mathrm{pp}$.

Krieger Lassen, N.C., 1996. The relative precision of crystal orientations measured from electron backscattering patterns. Journal of Microscopy, 181: 72-81.

Krogh, E.J., 1982. Metamorphic evolution deduced from mineral inclusions and compositional zoning in garnets from Norwegian country-rock eclogites. Lithos, 15: 305-321.

Kronenberg, A., Shelton, G., 1980. Deformation microstructures in experimentally deformed Maryland diabase. Journal of Structural Geology, 2: 341-354.

Krühl, J.H., Peternell, M., 2002. The equilibration of high-angle grain boundaries in dynamically recrystallized quartz: the effect of crystallography and temperature. Journal of Structural Geology, 24: 1125-1137.

Kriihl, J.K., 1987. Preferred lattice orientations of plagioclase from amphibolite and greenschist facies rocks near the Insubric Line (Western Alps). Tectonophysics, 135: 233-242.

Lagoeiro, L.E., 1998a. Mecanismos de deformação e orientações cristalográficas preferencias em tectonitos de formações ferríferas-quadrilátero ferrífero, MG: Universidade de São Paulo, São Paulo, 157 p.

Lagoeiro, L.E., 1998b. Transformation of magnetite to hematite and its influence on the dissolution of iron oxide minerals. Journal of Metamorphic Geology, 16: 415-423.

Lapworth, T., Wheeler, J., Prior, D.J., 2002. The deformation of plagioclase investigated using electron backscatter diffraction crystallographic preferred orientation data. Journal of Structural Geology, 24: 387-399.

Lardeaux, J.M., Gosso, G., Kienast, J.R., Lombardo, B., 1982. Relations entre le métamorphisme et la déformation dans la zone de Sesia-Lanzo (Alpes occidentales) et le problème de l'éclogitisation de la croûte continentale. Bulletin de la Société géologique de France, 24: 793 800.

Laubscher, H., 1990. The problem of the Moho in the Alps. Tectonophysics, 182: 9-20.

Lavie, M.P., 1998. Déformation expérimentale du diopside polycristallin. Ph.D. thesis: Paris XI Orsay, 175 p.

Lebensohn, R.A., Tomé, C.N., 1993. A self-consistent anisotropic approach for the simulation of plastic deformation and texture development of polycrystals: application to zirconion alloys. Acta metallurgica et materialia, 41: 2611-2624. 
Lister, G.S., Dornsiepen, U.F., 1982. Fabric transitions in the Saxony granulite terrain. Journal of Structural Geology, 4: 81-92.

Lister, G.S., Paterson, M.S., Hobbs, B.E., 1978. The simulation of fabric development during plastic deformation and its application to quartzite: the model. Tectonophysics, 45: 107-158.

Lloyd, G.E., Mainprice, D., Law, R.D., Wheeler, J., 1992. Microstructures and crustal fabric instabilities in shear zone evolution. Journal of Structural Geology, 14: 1079-1100.

Lloyd, G.E., Prior, D.J., 1999. EBSD technique and application in Geosciences. Göttinger Arbeiten zur Geologie und Paläontologie, Sb4: S.112-113.

Lloyd, G.E., Schmidt, N.H., Mainprice, D., Prior, D.J., 1991. Crystallographic textures. Mineralogical Magazine, 55: 331-345.

Machado, N., Vallares, C., Heilbron, M., Valeriano, C., 1996. U.Pb geochronology of the central Ribeira belt (Brazil) and implications for the evolution of the Brazilian Orogeny. Precambrian Research, 79: 347361 .

Machado, R., 1997. Litogeoquímica e tectônica dos granitóides Neoproterozóicos do cinturão Paraíba do Sul no estado do Rio de Janeiro. Livre-Docente: USP, São Paulo, Brasil, 215 p.

Machado, R., Demange, M., 1994. Classificação estrutural e tectônica dos granitóides Neoproterozóicos no Cinturão Paraíba do Sul no Estado do Rio de Janeiro. Boletim do IG-USP, Série Científica, 25: 81-96.

Machado, R., Endo, I., 1993. A Megaestrutura em Flor Positiva do vale do Rio Paraíba do Sul no Rio de Janeiro, e suas Implicações Tecônicas Regionais. In: III Simpósio de Geologia do Sudeste. Rio de Janeiro, Brasil 208-213.

Mainprice, D., 1990. A FORTRAN program to calculate seismic anisotropy from the lattice preferred orientation of minerals. Comput. Geosci., 16: 385-393.

Mainprice, D., Humbert, M., 1994. Methods of calculating petrophysical properties from lattice preferred orientation data. Surveys in Geophysics, 15: 575-592.

Mainprice, D., Lloyd, G., Casey, M., 1993. Individual orientation measurements in quartz polycrystals: advantages and limitations for texture and petrophysical property determinations. Journal of Structural Geology, 15: 1169-1187.

Mainprice, D., Nicolas, A., 1989. Development of shape and lattice preferred orientations: application to the seismic anisotropy of the lower crust. Journal of Structural Geology, 11: 175-189.

Mainprice, D., Silver, P.G., 1993. Interpretation of SKS-waves using samples from the subcontinental lithosphere. Physics of the Earth and Planetary Interiors, 78: 257-280.

Mainprice, D.H., Paterson, M.S., 1984. Experimental studies on the role of water in the plasticity of quartzites. Journal of Geophysical Research, 89: 4257-4269.

Manghnani, M.H., Ramananantoandro, R., Clark, S.P. Jr, 1974. Compressional and shear wave velocities in granulite facies rocks and eclogites to $10 \mathrm{kbar}$. Journal of Geophysical Research, 79: 5427.5446.

Masuda, T., Morikawa, T., Nakayama, Y., Suzuki, S., 1997. Grain-boundary migration of quartz during annealing experiments at high temperatures and pressures, with implications for metamorphic geology. Journal of Metamorphic Geology, 15: 311-322.

Mauler, A., Burlini, L., Kunze, K., Philippot, P., Burg, J.P., 2000a. P-wave anisotropy in eclogites and relationship to the omphacite crystallographic fabric. Physics and Chemistry of the Earth, 25: 119-126.

Mauler, A., Bystricky, M., Kunze, K., Mackwell, S., 2000b. Microstructure and lattice preferred orientations in experimentally deformed clinopyroxene aggregates. Journal of Structural Geology, 22: 1633-1648.

Mauler, A., Godard, G., Kunze, K., 2001. Crystallographic fabrics of omphacite, rutile and quartz in Vendée eclogites (Armorican Massif, France). Consequences for deformation mechanisms and regimes. Tectonophysics, 342: 81-112.

Mauler, A., Kunze, K., Burg, J.P., Philippot, P., 1998. Identification of EBSD patterns in a monoclinic solidstate solution series: Example of omphacite. Materials Science Forum, 275: 705-710.

McGeary, S., 1989. Reflection seismic evidence for a Moho offset beneath the Walls boundary strike-slip fault. Journal of the Geological Society of London, 146: 261-269. 
McNamara, D.E., Owens, T.J., 1993. Azimuthal shear wave velocity anisotropy in the Basin and Range province using Moho Ps converted phases. Journal of Geophysical Research, 98: 12003-12017.

McSkimin, H.J., Anreatch, J.R., Thurston, R.N., 1965. Elastic moduli of quartz versus hydrostatic pressure at $25^{\circ}$ and $-195.8^{\circ} \mathrm{C}$. Journal of Applied Physics, 36: 1624-1632.

Mercier, J.C., 1985. Olivine and pyroxenes. In: Wenk, H.R. (Ed.), Preferred orientation in deformed metals and rocks: An introduction to modern texture analysis. Orlando: Academic Press, 407-430 pp.

Messiga, B., Kienast, J.R., Rebay, G., Riccardi, M.P., Tribuzzio, R., 1999. Cr-rich magnesiochloritoid eclogites from the Monviso ophiolites (Western Alps, Italy). Journal of Metamorphic Geology, 17: 287-299.

Möckel, J.R., 1969. Structural petrology of the garnet-peridotite of Alpe Arami (Ticino, Switzerland). Leidse Geologische Medelingen, 42: 61-130.

Molinari, A., Canova, G.R., Azhy, S., 1987. A self-consistent approach of the large deformation crystal polycrystal viscoplasticity. Acta Metallurgica, 35: 2983-2994.

Montardi, Y., Mainprice, D., 1987. A TEM study of the natural plastic deformation of calcic plagioclase (An 6870). Bulletin de Minéralogie, 110: 1-14.

Mügge, O., 1883. Beiträge zur Kenntnis der Strukturflächen des Kalkspaths. Neues Jahrbuch fur Mineralogie, 1: $32-54,81-85$.

Mügge, O., 1898. Uber translation und verwandte erscheinungen in kristallen. Neues Jahrbuch Mineralogie, Geologie und Palaeontologie, 1: 71-158.

Nazé, L., Doukhan, N., Doukhan, J.C., Latrous, K., 1987. TEM study of lattice defects in naturally and experimentally deformed orthpyroxenes. Bulletin de Minéralogie, 110: 497-512.

Nicolas, A., 1984. Principes de tectonique. Paris: Masson, 223 p.

Nicolas, A., Bouchez, J.L., Boudier, F., 1972. Interprétation cinématique des déformations plastiques dans le massif de lherzolites de Lanzo. Tectonophysics, 14: 143-171.

Nicolas, A., Boudier, F., Boullier, A.M., 1973. Mechanism of flow in naturally and experimentally deformed peridotites. American Journal of Science, 273: 853 876.

Nicolas, A., Christensen, N.I., 1987. Formation of anisotropy in upper mantle peridotites - a review. In: Fuchs, K., Froidevaux, C. (Eds.), Composition, Structure and Dynamics of the Lithosphere-Asthenosphere System. Washington: AGU, $16111-123 \mathrm{pp}$.

Nicolas, A., Poirier, J.P., 1976. Crystalline plasticity and solid state flow in metamorphic rocks. New York: Wiley, $444 \mathrm{p}$.

Nicolas, A., Polino, R., Hirn, A., Nicolich, R., 1990. ECORS-CROP traverse and the deep structure of the western Alps: a synthesis. Mémoires de la Société Géologique de France, 156: 15-27.

Nye, J.F., 1972. Physical properties of crystals. Their representation by tensors and matrices. Oxford: Oxford University Press, $329 \mathrm{p}$.

Park, Y., Ree, J.-H., Kim, S., 2001. Lattice preferred orientation in deformed-then-annealed material: observations from experimental and natural polycrystalline aggregates. International Journal of Earth Sciences, 90: 127-135.

Passchier, C.W., Trouw, R.A.J., 1996. Microtectonics. Berlin: Springer, 289 p.

Passhier, C.W., 1994. Mixing in flow perturbations: a model for development of mantled porphyroclasts in mylonites. Journal of Structural Geology, 5: 733-736.

Pedrosa-Soares, A.C., Vidal, P., Leonardos, O.H., Britos Neves, B.B., 1998. Neoproterozoic oceanic remnants in eastern Brazil: further evidence and refutation of an exclusively ensialic evolurtion for the Araçuaí - West Congo orogen. Geology, 26: 519-522.

Peselnick, L., Nicolas, A., Stevenson, P.R., 1974. Velocity anisotropy in a mantle peridotite from the Ivrea Zone: Application to upper mantle anisotropy, Journal of Geophysical Research, 79: 1175 1182.

Philippot, P., 1987. Crack-seal vein geometry in eclogitic rocks. Geodinamica Acta, 3: 171-181.

Philippot, P., Kienast, J.R., 1989. Chemical-microstructural changes in eclogitic shear zones, Monviso (Western Alps), as indicators of strain history, mechanisms and scales of mass transfer. Lithos, 23: 179-200. 
Philippot, P., Van Roermund, H.L.M., 1992. Deformation processes in eclogitic rock: evidence for the theological delamination of the oceanic crust in deeper levels of subduction zones. Journal of Structural Geology, 14: 1059-1077.

Piepenbreier, D., Stöckert, B., 2001. Plastic flow of ompfacite in eclogites at temperatures below $500^{\circ} \mathrm{C}$ implications for interplate coupling in subduction zones. Internation Journal of Earth Sciences, 90: 197 210.

Pin, C., Sills, J.D., 1986. Petrogenesis of layered gabbros and ultramafic rocks from Val Sesia, NW Italy: trace elements and isotope geochemistry. In: Dawson, J.B., Carswell, D.A., Hall, J., Wedepohl, K.H. (Eds.), The nature of the continental crust. London: Geological Society Special Publication, 24 231-249 pp.

Poirier, J.P., 1985. Creep of crystals. High temperature deformation processes in metals, ceramics and minerals. Cambridge: Cambridge University Press, 260 p.

Porcher, C., Fernandes, L., Droop, G., Brodie K.H., 2000. Re-equilibration of granulites in a transcurrent shear zone in southeastern Brazil. In: Rio de Janeiro: 31st International Geological Congress.

Porcher, C., Fernandes, L., Egydio-Silva, M., Vauchez, A., 1995. Dados preliminares do metamorfismo MI da Faixa Ribeira: Regiăo de Três Rios e Santo Antônio de Pádua (RJ). In: V Simpósio Nacional de Estudos Tectônicos. Gramado (RS), Brasil 71-73.

Prior, D.J., Wheeler, J., 1999. Felspar fabrics in a greenschist facies albite-rich mylonite from electron backscatter diffraction. Tectonophysics, 303: 29-49.

Randle, V., Engler, O., 2000. Introduction to texture analysis: Gordon and Breach Science, $388 \mathrm{p}$.

Raposo, M.I.B., 2001. Magnetic fabric studies in the metamorphic rocks from the Ribeira belt, SE Brazil. In: 26th European Geophysical Society Meeting. Nice, France 2.

Raposo, M.I.B., D'Agrella-Filho, M.S., 2000. Magnetic fabrics of dike swarms from SE Bahia State, Brazil: their significance and implications for Mesoproterozoic basic magmatism in the São Francisco Craton. Precambrian Research, 99: 309-325.

Raposo, M.I.B., Egydio-Silva, M., 2001. Magnetic fabric studies of high-grade metamorphic rocks from the Juiz de Fora Complex, Ribeira belt, SE Brazil. International Geology Review, 43: 441-456.

Raterron, P., Doukhan, N., Jaoul, O., Doukhan, J.C., 1994. High temperature deformation of diopside IV: predominance of $\{110\}$ glide above $1000^{\circ} \mathrm{C}$. Physics of the Earth and Planetary Interiors, 82: 209-222.

Raterron, P., Jaoul, O., 1991. High-temperature deformation of diopside single crystal. 1, Mechanical data. Journal of Geophysical Research, 96: 14277-14286.

Ree, J., Park, Y., 1997. Static recovery and recrystallisation microstructures in sheared octachloropropane. Journal of Structural Geology, 19: 1521-1526.

Reuss, A., 1929. Berechnung der fliessgrenze von mischkristallen auf Grund der Plastizitätsbedingung fuer Einkristalle. Z. Angew. Math. Mech., 9: 49-58.

Rey, P., Fountain, D.M., Clement, P.C., 1994. P wave velocity across a noncoaxial shear zone and its associated strain gradient: Consequences for upper crustal reflectivity. Journal of Geophysical Research, 99: 45334548 .

Reynard, B., Gillet, P., Willaime, C., 1989. Deformation mechanisms in naturally deformed glaucophanes: a TEM and HREM study. European Journal of Mineralogy, 1: 611-624.

Rochette, P., 1989. Inverse magnetic fabric carbonate bearing rocks. Earth and Planetary Science Letters, 90: 229-237.

Rochette, P., Jackson, M., Aubourg, C., 1992. Rock magnetism and the interpretation of anisotropy of magnetic susceptibility. Reviews of Geophysics, 30: 209-226.

Rosière, C.A., Quade, H., Siemes, H., Chemale Jr., F., 1998. Fabric, Texture and Anisotropy of Magnetic Susceptibility in High-Grade Iron Ores from the Quadrilátero Ferrífero, Minas Gerais, Brazil. Materials Science Forum, 273-275: 693-700.

Rosière, C.A., Siemes, H., Quade, H., Brokmeier, H.-G., Jansen, M., 2001. Microstructures, textures and deformation mechanisms in hematite. Journal of Structural Geology, 23: 1429-1440. 
Ross, V.R., Nielsen, K.C., 1978. High-temperature flow of wet polycrystalline enstatite. Tectonophysique, 44: 233-261.

Rubie, D.C., 1984. A thermal-tectonic model for high-pressure metamorphism and deformation in the Sesia Zone, Western Alps. Journal of Geology, 92: 21-36.

Ryzhova, T.V., Aleksandrov, K.S., Korobkova, V.M., 1966. The elastic properties of rock-forming minerals V. Additional data on sillicates. Izvestiya. Physics of the Solid Earth, 2: 63-65.

Savage, M.K., Shih, X.R., Meyer, R.P., Aster, R.C., 1989. Shear-wave anisotropy of active tectonic regions via automated S-wave polarization analysis. Tectonophysics, 165: 279-292.

Schmid, E., Boas, W., 1950. Plasticity of crystals with special reference to metals. London, $352 \mathrm{p}$.

Schmid, S.M., Boland, J.M., Paterson, M.S., 1977. Superplastic flow in fine grained limestone. Tectonophysics, 43: 257-291.

Schmid, S.M., Casey, M., 1986. Complete fabric analysis of some commonly observed quartz c-axis patterns. In: Heard, H.C., Hobbs, B.E. (Eds.), Mineral and rock deformation: laboratory studies-The Paterson Volume. Washington: AGU monograph, 36 263-286 pp.

Schmidt, N.H., Olesen, N.Ø., 1989. Computer-aided determination of crystal-lattice orientation from electronchanneling patterns in the SEM. Canadian Mineralogist, 27: 15-22.

Schmitt, R.S., Trouw, R.A.J., Van Schmus, W.R., 1999. The characterization of Cambrian ( 520 Ma) tectonometamorphic event in the coastal domain of the Ribeira Belt (SE BRAZIL) - using U/Pb in syntectonic veins. In: II South American Symposium on Isotope Geology. Villa Carlos Paz, Córdoba, Argentina Special Volume of Expanded Abstract 363-366.

Siegesmund, S., Takeshita, T., Kern, H., 1989. Anisotropy of Vp and Vs in an amphibolite of the deeper crust and its relationship to the mineralogical, microstructural and textural characteristics of the rock. Tectonophysics, 157: 25-38.

Siegesmund, S., Vollbrecht, A., Nover, G., 1991. Anisotropy of compressional wave velocities, complex electrical resistivity and magnetic susceptibility of mylonites from the deeper crust and their relation to the rock fabric. Earth and Planetary Science Letters, 105: 247-259.

Siemes, H., Hennig-Michaeli, C., 1985. Ore minerals. I $n$ : Wenk, H.-R. (Ed.), Preferred orientation in deformed metals and rocks: an introduction to modern texture analysis. New York: Academic press, 335-358 pp.

Siemes, H., Klingenberg, B., Dresen, G., Rybacki, E., Nauman, M., Schäfer, W., Jansen, E., Rosière, C.A., 1999. Experimentally and naturally deformed hematite ores. In: VII Simpósio Nacional de Estudos Tectônicos. Lençois, Brasil 59, Sessão 5.

Siemes, H., Schaeben, H., Rosière, C.A., Quade, H., 2000. Crystallographic and magnetic preferred orientation of hematite in banded iron ores. Journal of Structural Geology, 22: 1747-1759.

Silver, P.G., Chan, W., 1988. Implications for continental structure and evolution from seismic anisotropy. Nature, 335: 34-39.

Söllner, F., Lammerer, B., Weber-Diefenbach, K., 1991. Die krustenentwicklung in der kustenregion nordlich von Rio de Janeiro/Brasilien. Münchner Geologische Helfe, 4: 1-101.

Starkey, J., 1979. Petrofabric analysis of Saxony Granulites by optical and X-ray diffraction methods. Tectonophysics, 58: 201-219.

Stesky, R.M., Brace, W.F., Riley, D.K., Robin, P.Y.F., 1974. Friction in faulted rock at high temperature and pressure. Tectonophysics, 23: 177-203.

Stöckert, B., Renner, J., 1998. Rheology of crustal rocks at ultra-high pressure. In: Hacker, B.R., Liou, J.G. (Eds.), When continents collide: Geodynamics and geochemistry ultrahigh-pressure. Dordrecht: Kluwer, $57-95 \mathrm{pp}$.

Tarling, D.H., Hrouda, F., 1993. The Magnetic Anisotropy of Rocks. London: Chapman and Hall, 217 p.

Taylor, G.I., 1938. Plastic strain in metals. Journal of the Institute of metals, 62: 301-324.

Thélin, P., 1989. Essai de chronologie magmatico-métamorphique dans le socle de la nappe du Grand SaintBernard: quelques points de repère. Schweizerische Mineralogische und Petrographische Mitteilungen, 69: 193-204. 
Thélin, P., Sartori, M., Lengeler, R., Schaerer, J.P., 1990. Eclogites of Paleozoic or early Alpine age in the basement of the Penninic Siviez-Mischabel nappe, Wallis, Switzerland. Lithos, 25: $71-88$.

Tommasi, A., Mainprice, D., Canova, G., Chastel, Y., 2000. Viscoplastic self-consistent and equilibrium-based modeling of olivine lattice preferred orientations. Implications for upper mantle seismic anisotropy. Journal of Geophysical Research, 105: 7893-7908.

Trindade, R.L.F., Raposo, M.I.F., Ernesto, M., Siqueira, R., 1999. Magnetic susceptibility and partial anhysteretic remanence anisotropies in the magnetite bearing granite pluton of Tourão, NE Brazil. Tectonophysics, 314: 443-468.

Trompette, R., 1994. Geology of western Gondwana (2000 - 500 Ma). Rotterdam: Balkema, 350 p.

Trouw, R., Heilbron, M., Ribeiro, A., Paciullo, F., Valeriano, C.M., Almeida, J.C.H., Tupinambá, M., Andreis, R.R., 2000. The Central Segment of the Ribeira Beit. In: Cordani, U.G., Milani, E.J., Thomaz Filho, A., Campos, D.A. (Eds.), Tectonic Evolution of South America. Rio de Janeiro: 31 st International Geological Congress, $287-310 \mathrm{pp}$.

Tullis, J., Christie, J.M., Griggs, D.T., 1973. Microstructures and preferred orientations of experimentally deformed quartzites. Geological Society of America Bulletin, 84: 297-314.

Tullis, J., Yund, R.A., 1991. Diffusion creep in feldspar aggregates: experimental evidence. Journal of Structural Geology.

Tupinambá, M., 1999. Evolução tectônica e magmática da Faixa Ribeira na região da Serra dos Órgãos. Tese de Doutoramento: USP, São Paulo, Brasil, 186 p.

Urai, J.L., Means, W.D., Lister, G.S., 1986. Dynamic recrystallization of minerals. In: Hobbs, B.E., Heard, H.C. (Eds.), Mineral and rock deformation: Laboratory studies. Washington, DC: AGU, 161-199 pp.

Uyeda, Y., Fuller, M.D., Belshé, J.C., Girdler, R.W., 1963. Anisotropy of magnetic susceptibility of rocks and minerals. Journal of Geophysical Research, 68: 279-291.

Valladares, C.S., 1996. Evoluções geológica do Complexo Paraíba do Sul, no segmento central da Faixa Ribeira, com base em estudos de geoquímica e de geocronologia U.Pb. Tese de Doutoramento: São Paulo, São Paulo, $147 \mathrm{p}$.

Van Roermund, H.L.M., 1983. Petrofabrics and microstructures of omphacites in a high temperature eclogite from the Swedish Caledonides. Bulletin de Minéralogie, 106: 709-713.

Van Roermund, H.L.M., Boland, J.N., 1981. The dislocation substructures of naturally deformed omphacites. Tectonophysics, 78: 403-418.

Vauchez, A., 1980. Ribbon texture and deformation mechanisms of quartz in a mylonitized granite of Great Kabylia (Algeria). Tectonophysics, 67: 1-12.

Vauchez, A., 1987. The development of discrete shear-zones in a granite: stress, strain and changes in deformation mechanisms. Tectonophysics, 133: 137-156.

Vauchez, A., Bufalo, M., 1988. Charriage crustal, anatexie et décrochements ductiles dans les Maures orientales (Var, France) au cours de l'orogenèse varisque. Geologisches Rundschau, 77: 45-62.

Vauchez, A., Garrido, C.J., 2001. Seismic Properties of an Asthenospherized Lithospheric Mantle: Constraints from Lattice Preferred Orientations in Peridotite from the Ronda Massif. Earth and Planetary Science Letters, 192: 235-249.

Vauchez, A., Nicolas, A., 1991. Mountain building: strike-parallel motion and mantle anisotropy. Tectonophysics, 185: 183-191.

Vauchez, A., Pacheco-Neves, S., Caby, R., Corsini, M., Egydio-Silva, M., Arthaud, M., Amaro, V., 1995. The Borborema shear zone system. Journal of South American Earth Sciences, 8: 247-266.

Vauchez, A., Tommasi, A., 2002. Wrench faults down to the asthenosphere : Geological and geophysical evidence and thermo-mechanical effects. Tectonophysics, in press.

Vauchez, A., Tommasi, A., Egydio-Silva, M., 1994. Self-indentation of continental lithosphere. Geology, 22: 967-970. 
Venables, J.A., Harland, C.J., 1973. Electron back-scattering patterns-a new technique for obtaining crystallographic information in the scanning electron microscope. Philosophical Magazine, 27: 11931200 .

Voegele, V., Ando, J.I., Cordier, P., Libermann, R.C., 1998. Plastic deformation of silicate garnet I. Physics of the Earth and Planetary Interiors, 108: 305-318.

Voigt, W., 1928. Lerrbuch der Kristallphysik. Leipzig, 978 p.

Von Mises, R., 1928. Mechanik der plastichen Formanderung von kristallen. Z. Angew. Math. Mech., 8: 161. 185.

Warner, M., Morgan, J., Barton, P., Morgan, P., Price, C., Jones, K., 1996. Seismic reflections from the mantle represent relict subduction zones within the continental lithosphere. Geology, 24: 39-42.

Wechsler, B.A., Prewitt, C.T., 1984. Crystal structure of ilmenite (FeTiO3) at high temperature and at high pressure. American Mineralogist, 69: 176-185.

Weidner, D.J., Wang, H., Ito, J., 1978. Elasticity of orthoenstatite. Physics of the Earth and Planetary Interiors, 17: $7-13$.

Wells, P.R.A., 1977. Pyroxene thermometry in simple and complex systems. Contributions to Mineralogy and Petrology, 62: 129-139.

Wenk, H.-R., Bennet, K., Canova, G.R., Molinari, A., 1991. Modelling plastic deformation of peridotite with the self-consistent theory. Journal of Geophysical Research, 96: 8337-8349.

Wenk, H.-R., Canova, G., Molinari, A., Kocks, U.F., 1989. Viscoplastic modeling of texture development in quartzite. Journal of Geophysical Research, 94: 17895-17906.

Wenk, H.-R., Christie, J.M., 1991. Comments on the interpretation of deformation textures in rocks. Journal of Structural Geology, 13: 1091-1110.

Will, G., Schäfer, P., Merz, P., 1989. Texture analysis by neutron diffraction using a linear position sensitive detector. Textures and Microstructures, 10: 375-387.

Wilson, C.J.L., 1986. Deformation-induced recrystallization of ice: Application of in-situ experiments. In: Hobbs, B.E., Heard, H.C. (Eds.), Mineral and rock deformation: Laboratory studies. Washington, DC: AGU, 213-232 pp.

Wirth, R., 1985. The influence of the low high quartz transformation on recrystallization and grain growth during contact metamorphism (trasversella intrusion, north Italy). Tectonophysics, 120: 107-117.

Woodcock, N.H., Naylor, M.A., 1983. Randomless testing in three-dimensional orientation data. Journal of Structural Geology, 5: 539-548.

Yaouancq, G., MacLeod, C.J., 2000. Petrofabric investigation of gabbros from the Oman ophiolite: comparison between AMS and rocks fabric. Marine Geophysical Researches, 21: 289-305.

Zhang, R.Y., Hirajima, T., Banno, S., Cong, B., Liou, J.G., 1995. Petrology of ultrahigh-pressure rocks from the southern Su-Lu region, eastern China. Journal of Metamorphic Geology, 13: 659-675. 
$\overline{\text { SOXENV }}$ 


\section{$\overline{I O X \overline{A N V}}$}




\title{
TECTONOPHYSICS
}

\section{EBSD-measured lattice-preferred orientations and seismic properties of eclogites}

\author{
Jérôme Bascou ${ }^{\mathrm{a} b \mathrm{~b}, *}$, Guilhem Barruol ${ }^{\mathrm{a}}$, Alain Vauchez ${ }^{\mathrm{a}}$, David Mainprice ${ }^{\mathrm{a}}$, \\ Marcos Egydio-Silva ${ }^{b}$ \\ "Laboratoire de Tectonophysique, Université de Montpellier II and CNRS UMR 5568-cc049, Place E. Bataillon. \\ 34095 Montpellier cedex 5. France \\ bInstituto de Geociências, Universidade de São Paulo, Rua do lago 562, Cep: 05508-900, C.P. 11358 Säo Paulo, Brazil
}

Received 10 July 2000 ; accepted 3 December 2000

\begin{abstract}
We investigated the deformation mechanisms and the seismic properties of 10 eclogite samples from different localities (Alps, Norway, Mali and eastern China) through the analysis of their microstructures and lattice-preferred orientations (LPO). These samples are representative of various types and intensity of deformation under eclogitic metamorphic conditions. Omphacite and garnet LPO were determined from electron backscatter diffraction (EBSD) technique. Garnet appears to be almost randomly oriented whereas omphacite develops strong LPO, characterized by the [001]-axes concentrated sub-parallel to the lineation, and the (010)-poles concentrated sub-perpendicular to the foliation. In order to analyze the deformation mechanisms that produced such omphacite LPO, we compare our observations to LPO simulated by viscoplastic selfconsistent numerical models. A good fit to the measured LPO is obtained for models in which the dominant slip systems ate $1 / 2\langle 110\rangle\{1 \overline{1} 0\},[001]\{110\}$ and [001] (100). Dominant activation of these slip systems is in agreement with TEM studies of naturally deformed omphacite. Seismic properties of eclogite are calculated by combining the measured LPO and the single crystal elastic constants of omphacite and garnet. Although eclogite seismic anisotropies are very weak (less than $3 \%$ for both $\mathrm{P}$ - and $\mathrm{S}$-wave), they are generally characterized by a maximum $\mathrm{P}$-wave velocity sub-parallel to the lineation and by a minimum velocity approximately normal to foliation. The mean P- and S-wave velocities are high (respectively, 8.6 and 4.9 $\mathrm{km} / \mathrm{s}$ ). The S-wave anisotropy pattern displays complex relationships with the structural frame but the fast polarization plane generally tends to be parallel to the foliation. Calculated reflection coefficients show that an eclogite/crust interface is generally a good reflector $(\mathrm{Rc}>0.1)$, whereas an eclogite body embedded in the upper mantle would be hardly detectable. (C) 2001 Elsevier Science B.V. All rights reserved.
\end{abstract}

Keyworls; Electron backscatter diffaction (EBSD); Lattice-preferred orientation (LPO); Omphacite deformation; Numerical models; Seismic anisotropy; Reflectivity

\section{Introduction}

- Corresponding author. Laboratoire de Tectonophysique, Université de Montpelier II et CNRS UMR 5568-cc049, Place E. Bataillon, 34095 Montpellier cedex 5, France.

E-mail address: bascou@dstu,univımontp2.fr (J. Bascou).
High-pressure rocks in collisional orogens are often regarded as relicts of subduction zones. Their detection is therefore fundamental in the understanding of the earth's dynamic. In particular, the pres- 
ence of eclogite bodies within the continental lithosphere could explain high velocity patches detected in seismic tomography models or bright seismic reflectors on deep seismic reflection profiles (Butler, 1986; Laubscher, 1990; Nicolas et al., 1990; Austrheim, 1991; Warner et al., 1996). Laboratory measurements of P- and S-wave velocities (e.g. Fountain et al., 1994; Kern et al., 1999) show that eclogites are characterized by $\mathrm{p}$-wave velocities around 8.0 $\mathrm{km} / \mathrm{s}$, which are much faster than the average $P$ wave velocities of other crustal rock (e.g. Barruol and Mainprice, 1993a; Christensen and Mooney 1995). These velocities are however similar to the average velocity in the uppermost mantle, i.e., 8.09 $\mathrm{km} / \mathrm{s}$ for the Pn-average velocity.

Possible effects of seismic anisotropy on the reflectivity of eclogite bodies in contact with peridotite have been pointed out by Mauler et al. (2000). Unfortunately, if peridotite seismic anisotropy and its relationship with olivine lattice-preferred orientation is widely documented (Babuska, 1972; Nicolas et al., 1973; Nicolas and Christensen, 1987; Ben Ismail and Mainprice, 1998), it is not the case of eclogitic rocks seismic properties. Eclogites seismic anisotropy is also expected to be controlled by the anisotropy of the elastic properties of omphacite single-crystal (Bhagat et al., 1992), but the relationship between the omphacite LPO, the deformation mechanisms and the resulting seismic properties is poorly documented (Godard and Van Roermund, 1995).

The overall aim of this paper is therefore to increase our knowledge on the eclogite physical properties. To access this point, (1) we quantify the crystallographic orientations of omphacite and garnet in eclogites sampled from various localities (Alps, Norway, Mali and eastern China) that display different types and intensity of deformation; (2) we discuss the deformation mechanisms that produce the measured omphacite LPO. The lack of experimental data on omphacite polycrystals deformation stimulates us to perform numerical models of LPO development by dislocation glide in order to constrain the relationship between LPO and slip systems activity; (3) we compute the seismic properties (P and $\mathrm{S}$ velocities) of the selected eclogites from their measured LPO; and (4) we finally discuss the reflectivity of horizontal interfaces involving eclogite, crustal and mantle rocks.

\section{Geological settings and textures description}

\subsection{Alpe Arami eclogites (Alps)}

The Alpe Arami peridotite massif is located within the Lepontine gneisses, north from the Insubric Line (Fig. 1). This lens-shaped peridotite massif, $1-\mathrm{km}$ long, is surrounded by eclogite boudins partly converted to an amphibolite assemblage (Möckel, 1969; Ernst, 1977). Thermobarometric investigations (Heinrich, 1986) suggest $P-T$ metamorphic conditions in the range $1.8-3.5 \mathrm{GPa}$ and $750-900^{\circ} \mathrm{C}$.

Sample AB.E is petrologicaly representative of the eclogitic event. It contains $60 \%$ of omphacite, $30 \%$ of garnet and rutile, ca-amphibole and kyanite as accessory minerals. This rock is characterized by a penetrative foliation and a lineation marked by a shape preferred orientation of omphacite crystals. The largest omphacite crystals are more than 4-mm long (Fig. 2a). The garnet crystals, weakly elongated, are roughly $800-\mu \mathrm{m}$ long in average and contain inclusions of omphacite.

\subsection{Mt Mucrone eclogites (Alps)}

In the Monte Mucrone area (Fig. 1), glaucophanebearing eclogitic boudins are embedded in the SesiaLanzo zone micaschists. These eclogites are characterized by a good preservation of the high-pressure mineralogical assemblages (Lardeaux et al., 1982; Rubie, 1984) and might represent a slice of Austroalpine continental crust subducted during the cretaceous Alpine collision (e.g. Compagnoni et al., 1977). The metamorphic conditions are estimated to be around $1.4-1.6 \mathrm{GPa}$ and $500-560^{\circ} \mathrm{C}$ (Lardeaux et al., 1982).

Sample eclo 01 is composed of omphacite $(55 \%)$, garnet $(25 \%)$, zoisite $(10 \%)$ and minor phengite, glaucophane and nutile. The microstructure is characterized by a bimodal distribution of omphacite grain size with large porphyroclasts $(>2 \mathrm{~mm}$ ) surrounded by fine grained recrystallized omphacite. The largest grains show undulose extinction and subgrain boundaries (Fig. 2b). Another class of omphacite crystals is made of elongated grains about 2-mm long that are free of sub-structure. The foliation is marked by zoisite-rich layers and the elongation of omphacite porphyroclasts. 

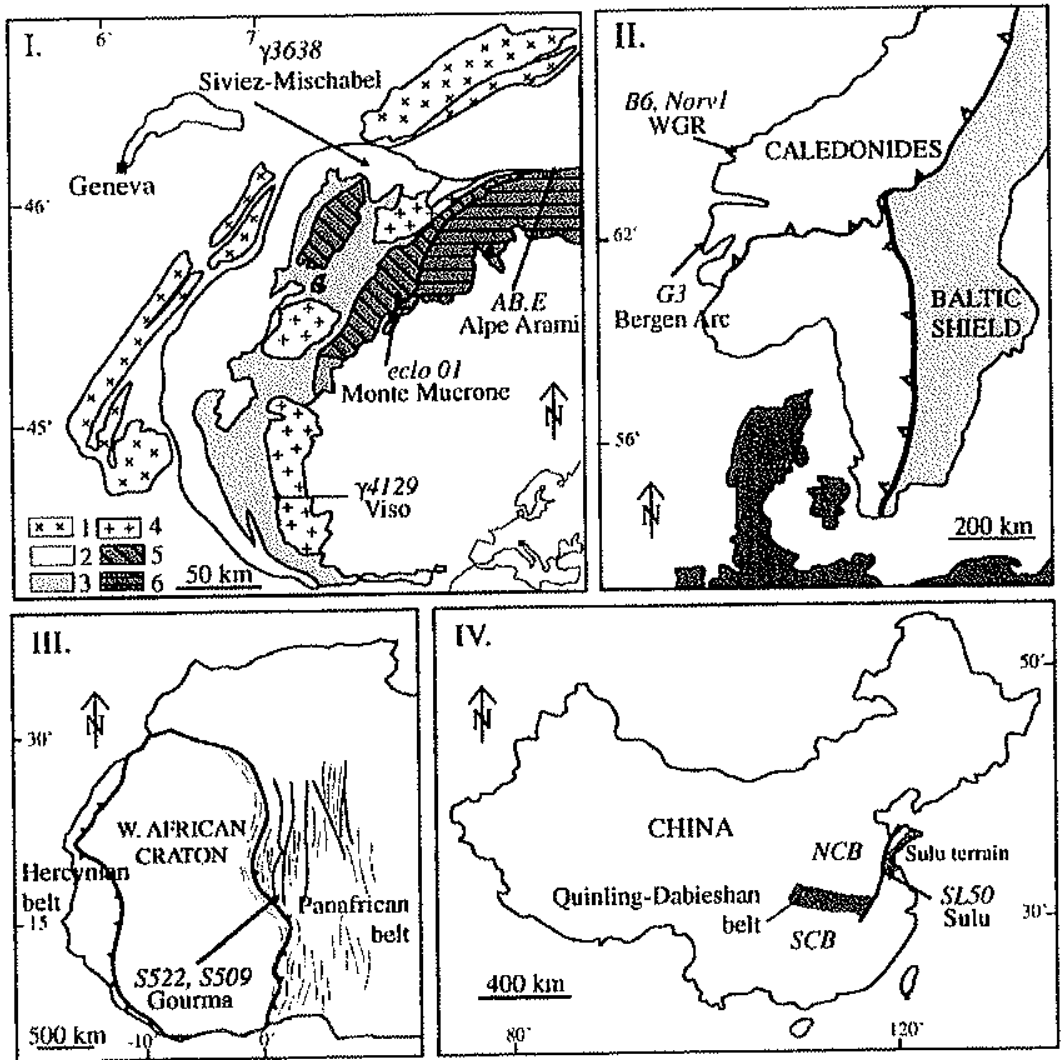

Fig. 1. Schematic mans showing the geographical and geological setting of the studied eclogite samples. (I) Alps region: AB.E, Alpe Arami

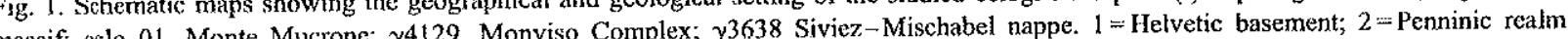
undifferentiated; $3=$ Piemonte zone (Penninic); $4=$ Monte Rosa, Gran Paradiso and Dora Maira nappes (Penninic basement); $5=$ Sesia Zone and (Flolsny island), Bergen Arc; B6 and Norv.1, Western Gneiss Region (WGR). (III) Mali area: S522 and S509, Gourma basin. (IV) Dabie and Sulu areas: SL50, Sulu terrain. NCB = North China Block, and $\mathrm{SCB}=$ South China Block.

\subsection{Monviso eclogites (Alps)}

The Monviso meta-ophiolitic complex is located in the Western Alps (Fig. 1). Eclogitic metamorphism is related to the subduction of an oceanic crust during the Alpine orogeny (e.g. Caby et al., 1978). The pressure and temperature conditions of the eclogitic metamorphism have been estimated to be $2.4 \mathrm{GPa}$ and $620 \pm 50^{\circ} \mathrm{C}$ (Messiga et al., 1999).

Sample $\gamma 4129$ (65\% omphacite, $20 \%$ garnet, $8 \%$ rutile) was collected within the highly deformed, eclogitic metagabbros outcropping in the Lago Superior Unit (Philippot and Kienast, 1989). This sample is characterized by a mylonitic foliation formed by fine $(<40 \mu \mathrm{m})$, recrystallized omphacite grains. Some large omphacite grains ( $>1 \mathrm{~mm}$; Fig. $2 \mathrm{c}$ ) are remnants of the original texture; they display undulose extinction and subgrain boundaries. Garnet grains are small $(500 \mu \mathrm{m})$ and rounded. Fine layers of elongated and fragmented rutile grains underline the foliation and the lineation.

\subsection{Siviez-Mischabel nappe eclogites (Alps)}

These eclogites are located in the polymetamorphic basement of the Penninic Siviez-Mischabel nappe (Valais, Switzerland; Fig. 1). Eclogitization was not generated during Alpine orogeny but is supposed to have occurred during Paleozoic times at a temperature around $650^{\circ} \mathrm{C}$ and a pressure above $1.5 \mathrm{GPa}$ (Thélin et al., 1990). Lately, the high-pressure mineral assem- 

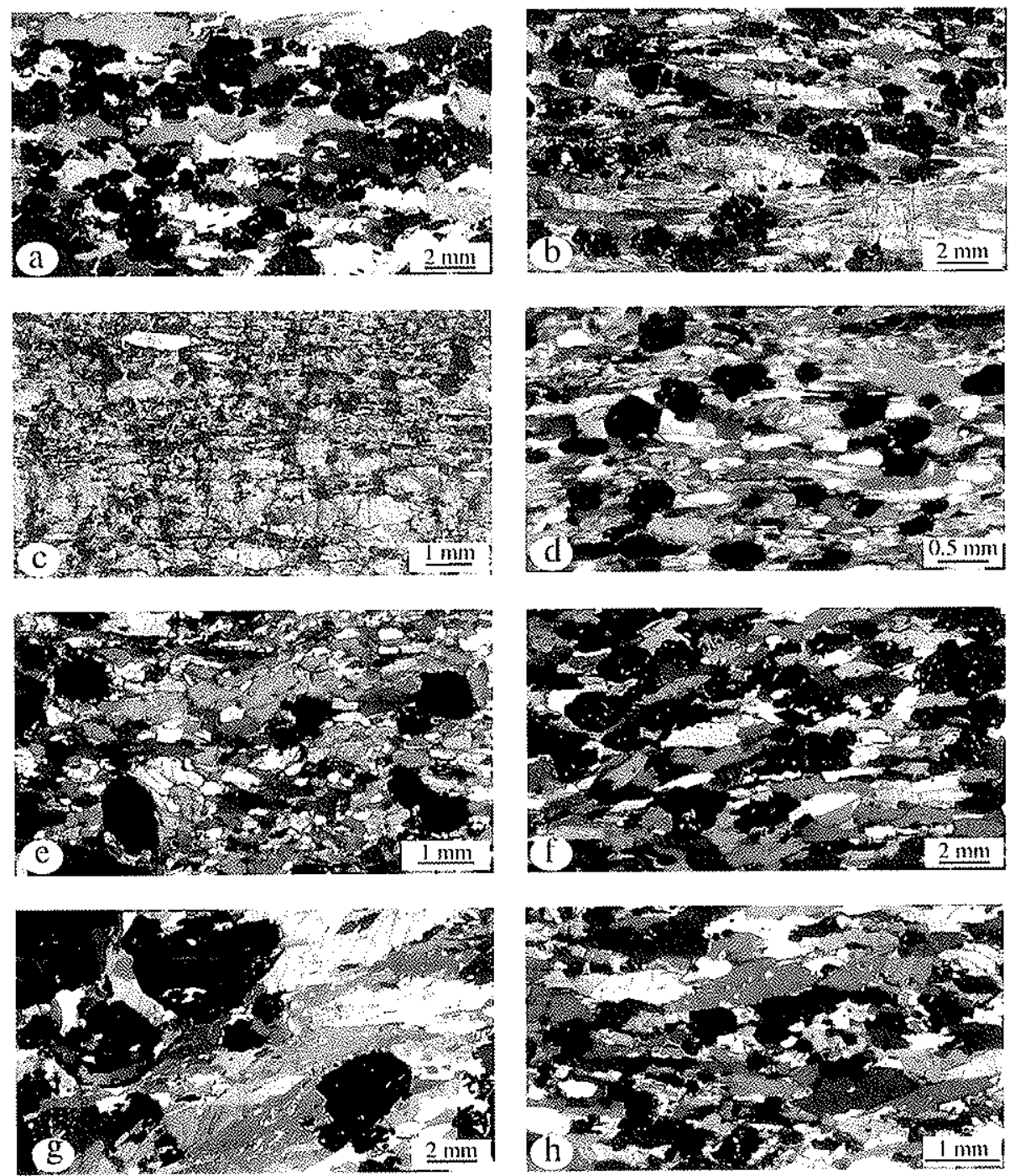

Fig. 2. Photomicrograplus showing typical microstrtctures of ectogite samples. (a) Sample AB.E; (b) sample eclo 01; (c) satmple $\gamma^{4129}$; (d) sample $\gamma 3638$; (c) sample G3; (f) sample B6; (g) sample Norvl; (h) sample S522. Thin sections in the XZ structural plane except g; g contains $X$-axis and makes an angle of $60^{\circ}$ with the $X Y$ plane. Polarized light.

blage has been partially retrogressed in the amphibolite- and greenschist-facies.

Sample $\gamma 3638$ was collected in the core of a decametric-scale boudin enclosed in retrogressed gneisses. It modal composition is primarily omphacite $(65 \%)$ and garnet $(20 \%)$. White mica, zoisite and kyanite are present as accessory components. In thin section (Fig. 2d), elongated crystals of omphacite as well as mica, zoisite and rutile underline the foliation.
Omphacite grains are submatomorphous and about $500-\mu \mathrm{m}$ long. Garnet grains are fractured and rounded.

\subsection{Bergen Are eclogites (Norway)}

The eclogites of series $\mathrm{G}$ (three samples) have been collected on Holsnøy Island (Western Norway; Fig. 1), within the Hundskjeften shear zone that crosscut granulite facies anorthositic complex of the Bergen 
Arc. This complex formed during the Proterozoic Grenvillian orogeny (i.e., I Ga) was subsequently strongly deformed and partially eclogitized during the Caledonian orogeny (Austrheim and Griffin, 1985; Austrheim, 1987). The pressure and temperature conditions of eclogitization were estimated to be around $1.8 \mathrm{GPa}$ and $700-800^{\circ} \mathrm{C}$ (Austrheim and Griffin, 1985).

The three samples of the series $G$ are fine grained and display similar modal content. Thus, we only present one of those samples (G3) in Fig. 2e; it is composed of omphacite $(65 \%)$, garnet $(25 \%)$ and minor phengite, zoisite and kyanite. Sub-automorphous omphacite crystals, $200-500-\mu \mathrm{m}$ long, mark the foliation. Garnet generally is rounded and generally millimetric in size. The other mineralogical phases are strongly elongated in the foliation.

\subsection{Western Gneiss Region eclogites (Norway)}

These eclogites are located within the Western Gneiss Region (WGR; Fig. 1), north of the Nordfjord-Sogn Detachment. This detachment was active during the late to post orogenic extension of the Caledonides and is thought to have played an important role in the exhumation of the WGR (Andersen, 1998).

Sample B6 is sampled from the core of an eclogite boudin that was retrogressed in the amphibolite metamorphic facies. In the core of this boudin, eclogite facies parageneses are still preserved. B6 contains $55 \%$ omphacite, $35 \%$ gamet plus minor quartz, phengite and rutile. Omphacite grains up to 2-mm long display a weak symplectization. A shape-preferred orientation of omphacite crystals marks the foliation and lineation. Garnet is inclusion-rich and millimetric in size (Fig. 2f).

Sample Norv1 (not in-situ) was collected in the Nordfjord area (Fig. 1). Mineral composition is omphacite $(60 \%)$, garnet $(30 \%)$, with kyanite, zoisite, phengite and quartz as minor components. This sample is coarse-grained with omphacite grains $>4 \mathrm{~mm}$ and large garnets (>3 mm; Fig. $2 \mathrm{~g}$ ) showing abundant amphibole and quartz inclusions.

\subsection{Gourma eclogites (Mali)}

Samples S522 and S509 represent eclogitic metasediments from the internal nappes of the Gourma area, northern Mali (Fig. 1). These eclogites are thought to represent sediments of a passive continental margin subducted during the closure of a pre-PanAfrican ocean. They might be exhumed during the Pan-African collision of the West African craton with an arc and/or with the Hoggar-Iforas continental margin (Caby, 1994). The eclogitic metamorphism occurred at pressure above $2.7 \mathrm{GPa}$ and temperature ranging between 700 and $750{ }^{\circ} \mathrm{C}$ (Caby, 1994).

In the calc-silicate sample S522 (Fig. 2h), coesite relics in omphacite have been described by Caby (1994). Omphacite represents the major mineral phase $(70 \%)$. The other phases are garnet, quartz, ankerite and accessory rutile and phengite. A penetrative foliation is defined by the shape fabric of tabular omphacite crystals $(>1.5 \mathrm{~mm})$. Garnet crystals are millimetric in size and rounded in shape. A finegrained matrix contains omphacite grains of about $400 \mu \mathrm{m}$, quartz and ankerite.

Sample $\$ 509$ was collected in a metabasic sill within micaschists. This sample is characterized by a mineralogical layering of omphacite-rich (+ quartz) and omphacite-poor, garnet-rich layers. In the omphacite-rich layers, omphacite displays evidence of an overgrowth with megacrysts above $1.5 \mathrm{~cm}$ in length containing abundant quartz inclusions. In omphacitepoor, garnet-rich layers, the grain size of omphacite and garnet is relatively homogeneous $(1-2 \mathrm{~mm})$.

\subsection{Sulu eclogites (eastern China)}

Dabie and Sulu areas are considered as the eastern extension of the Quinling-Dabishan orogenic belt, which results from a collision between the North and South China Blocks (Fig. 1). The occurrence of coesite in the Dabie and Sulu gneissic and eclogitic terranes indicates a subduction of the South China continental crust down to more than $100 \mathrm{~km}$ (e.g. Faure et al., 2001). In the Sulu terrain, the $P, T$ conditions were evaluated at ca. $700-890{ }^{\circ} \mathrm{C}$ and $P>2.8$ GPa (Zhang et al., 1995).

Studied eclogites were sampled in the southern part of the Sulu terrain. The less retromorphozed sample (SL50) is made of omphacite (70\%), garnet (20\%), quartz $(7 \%)$ and minor phengite, epidote, rutile and kyanite. Elongated crystals of omphacite (about $1 \times 3$ $\mathrm{mm}$ in size) underline the foliation and lineation. Garnet grains of about $0.8 \mathrm{~mm}$ are equidimensional 
and quartz grains up to $1-\mathrm{mm}$ long are strongly deformed.

\section{Electron backscatter diffraction (EBSD) measurements}

\subsection{Experimental setup and indexing procedure}

Omphacite and garnet lattice-preferred orientations (LPO) were measured on a scanning electron microscope JEOL JSM 5600 by electron backscatter diffraction techniques (EBSD; Lloyd et al., 1991; Adams et al., 1993; Dingley and Field, 1997). This technique is based on automatic analysis of diffraction patterns. These patterns composed of Kikuchi bands are generated by interaction of a vertical incident electron beam with a flat crystal surface. We used polished thin sections about $10 \mathrm{~cm}^{2}$ and tilted at $70^{\circ}$ from the horizontal within the microscope chamber. A phosphor screen is located close to the thin section to collect the backscattered electrons and to emit a photonic image of the EBSD pattern. A low-light, high-resolution camera acquires this photonic image, which is then processed and indexed using the CHANNEL + software (Schmidt and Olesen, 1989). At each point of measurement, the Euler angles $(\varphi 1, \phi, \varphi 2)$ characterizing the lattice orientation of the crystal are determined and stored together with the nature of the mineral. The whole procedure (pattern acquisition, image freezing, band detection, indexing and result backup) can be carried out automatically. The relative precision of crystal orientations measured from electron backscattering patterns is better than $1^{\circ}$ (Krieger Lassen, 1996).

In order to improve the quality of the diffraction patterns, relief on the thin section is minimized by a careful polishing. The polishing procedure ends with a $1 / 4-\mu \mathrm{m}$ diamond paste followed by a SYTON chemical polishing. In addition, charging effect were prevented by a slight platinum coating. EBSP were acquired at accelerating voltage of $15 \mathrm{kV}$ and a working distance of about $40 \mathrm{~mm}$.

Crystal orientation is determined by comparing the observed pattern of Kikuchi bands with those simulated for a pre-defined crystallographic structure. For each investigated mineral phase, one has there fore to generate first the crystallographic structure file
(Laïe group, unit cell parameters, atoms position within the unit cell) and calculate the corresponding database file containing the reflectors suitable for the best indexing. For garnet, we used a set of the 64 strongest reflections bands calculated from pyrope structure of cell edge $11.459 \AA$. For omphacite, we used a set of the 73 strongest Kikuchi bands calculated using the crystallographic data of a Norway omphacite (Clark et al., 1969). The weak impact on the reflection of the $\mathrm{C} 2 / \mathrm{c}$ to $\mathrm{P} 2 / \mathrm{n}$ ordering structure transformation (Mauler et al., 1998) in the omphacite compositional range, allows using a single omphacite hkl-file. Lattice-preferred orientations were measured in automatic mode when no electronic charging artifacts affected the pattern quality. Otherwise, we used a manual procedure. During automatic measurements, we used discriminators in order to reject suspicious indexings. These discriminators give a control on the pattern quality (band contrast and band slope parameters), but also on the indexation velocity (search rounds parameter) and on the quality of the agreement between detected and simulated Kikuchi bands (Mean Angular Deviation parameter). Data that did not fulfill the parameters were rejected. The diffraction pattern of mineral other than omphacite and garnet, as for example, kyanite, systematically produced a zero solution. For all the samples, the whole surface of the thin sections was investigated. Finally, the stage motorization allows a stepby-step measurement on a predefined grid. We choose a step size of the same order as the omphacite grain size of the studied sample (see Table 1), except for the sample Norv1, whose grain size was too large. In most cases, the relative small size of the mean grains relative to the thin section area secures a good sampling statistic in spite of a possible oversampling of the largest grains. In "manual" procedure, only the step size along the $Y$ direction was imposed, whereas along the $X$ direction, each new pattern was indexed by the operator avoiding dupliw cate measurements in the same grains (Table 1 summarizes all methodological information). For each sample, both omphacite and garnet were indexed. If omphacite displays significant lattice preferred orientations, it is not the case for garnet that is almost randomly oriented. For this reason, we concentrate our following microstructural analyze on omphacite. 
Table 1

$P, T$ conditions of eclogitic metamorphism, analytic data and grain size for the studied samples

\begin{tabular}{|c|c|c|c|c|c|c|}
\hline Samples & Sample location & $P(\mathrm{GPA}), T\left({ }^{\circ} \mathrm{C}\right)$ peak & $\begin{array}{l}\text { Mean } \\
\text { reference }\end{array}$ & $\begin{array}{l}\text { EBSD } \\
\text { procedure }\end{array}$ & Step $(\mu \mathrm{m})$ & Mean grain size $(\mu \mathrm{m})$ \\
\hline \multicolumn{7}{|c|}{ Alpine eclogites } \\
\hline AB.E & Alpe Arami & $1.8 \cdots 3.5,750 \cdots 900$ & {$[1]$} & manual & $y: 1000$ & \multirow{2}{*}{$\begin{array}{l}\text { omph: } 4000 \times 1000 ; \text { grt: } 800 \\
\text { omph: } 3000 \times 1000(\text { porph); } \\
<1000(\text { recr); grt: } 1000\end{array}$} \\
\hline Eclo 01 & Mt. Mucrone & i. $3-1.6,600-650$ & {$[2]$} & automatic & $x, y: 500$ & \\
\hline$\gamma 4129$ & Monviso & $>2.4,570-670$ & [3] & manual & $y: 500$ & $\begin{array}{l}\text { omph: } 2000 \times 500(\text { porph }) \\
<40 \text { (recr); grt: } 500 \times 300\end{array}$ \\
\hline$\gamma 3638$ & Siviez-Mischabel & $>1.5,620 \cdots 680$ & {$[4]$} & automatic & $x, y: 500$ & $\begin{array}{l}\text { omph: } 500 \times 200 \text {, matrix }<300 \text {; } \\
\text { grt: } 500\end{array}$ \\
\hline \multicolumn{7}{|c|}{ Norway eclogites } \\
\hline G1 & Bergen Arcs & $>1.8,700 \sim 750$ & {$[5]$} & manual & $y: 500$ & \multirow{2}{*}{$\begin{array}{l}\text { omph: } 500 \times 50 ; \text { grt: } 15000 \\
\text { omph1: } 1000 \times 300 \\
\text { omph2: } 200 ; \text { grt: } 2000\end{array}$} \\
\hline G2 & & & & automatic & $x, y: 300$ & \\
\hline G3 & & & & automatic & $x, y: 400$ & $\begin{array}{l}\text { omph: } 500 \times 200 \\
\text { gxt: } 1000 \times 1500\end{array}$ \\
\hline \multicolumn{7}{|c|}{ Western gneiss region } \\
\hline $\begin{array}{l}\text { B6 } \\
\text { Norv.1 }\end{array}$ & $\begin{array}{l}\text { Nordfjord area } \\
\text { (Verpeneset) }\end{array}$ & $1.4-1.6,650-700$ & {$[6]$} & $\begin{array}{l}\text { manual } \\
\text { atutomatic }\end{array}$ & $x, y: 1000$ & $\begin{array}{l}\text { omph: } 3000 \times 1000 ; \text { grt: } 2000 \\
\text { omph> } 4000 ; \text { grt>3000 }\end{array}$ \\
\hline \multicolumn{7}{|c|}{ Gourma eclogites } \\
\hline $\mathrm{S} 522$ & & $>2.7,700-750$ & {$[7]$} & manual & $y: 1000$ & \multirow{2}{*}{$\begin{array}{l}\text { omph: } 1500 \times 800 \text { and } \\
400 \times 200 ; \mathrm{grt}<1000 \\
\text { omph }>1000 ; \mathrm{grt}: 1000\end{array}$} \\
\hline $\mathrm{S} 509$ & & $>2.7,700-750$ & {$[7]$} & manual & $y: 1000$ & \\
\hline \multicolumn{2}{|c|}{ Stulu eclogites } & $>2.8,700-890$ & {$[8]$} & automatic & $x, y: 1000$ & omph: $3000 \times 1000 ;$ grt $<1000$ \\
\hline SL50 & & & & automatic & & \\
\hline
\end{tabular}

Omph: omphacite; grt: garnet; porph: porphyroclasts; recr: recrystallized grains. Figs. 3 and $S$ give the number of measurement $(N)$ of Omph: omphacite; grt: garnet; porph: porphyroclasts; recr: recrystallized grains. Figs. 3 and $S$ give the number of measurement (N) of
omphacite per sample. [1] Heinrich (1986); [2] Lardeaux et al. (1982); [3] Messiga et al. (1999); [4] Thélin et al. (1990); [5] Austrheim and Griffin (1985); [6] Krogh (1982); [7] Caby (1994); [8] Zhang et al. (1995).

\subsection{Omphacite lattice-preferred orientations}

Omphacite LPO is generally measured from thin section cut parallel to the structural $(X Z)$-plane, i.e., normal to the foliation and parallel to the lineation. The well-marked mineralogical foliation and lineation characterizing our samples ensures a good precision in the determination of the orientation of the structural $X-, Y$, and $Z$-axis $(X=$ lineation; $Z=$ pole of the foliation). The measured omphacite LPO (Figs. 3, 4 and 5) are presented on equal area, lower hemisphere projections in the structural $(X Z)$ reference frame. Foliation is vertical $E-W$ and the lineation is horizontal in this plane. Only sample Norvl was not cut parallel the (XZ)-plane and LPO of this sample was rotated a posteriori for easier comparison with the others samples.
Omphacite LPO (Figs. 3, 4 and 5) are characterized by strong concentrations of (010)-poles and [001]axes normal to the foliation and parallel to the lineation, respectively. [100]-axes and (110)-poles are poorly oriented. However, (110)-poles tend to concentrate in a girdle perpendicular to the lineation with a maximum at ca. $60^{\circ}$ to the foliation. [100]-axes display a maximum of concentration close to the $Y$ structural axis (i.e., normal to the lineation within the foliation) is often observed.

Besides these general features, LPO variations are observed from sample to sample. Sample AB.E from Alpe Arami (Fig. 3) displays the best concentration of (010)-poles close to the $Z$-axis. A weak but significant obliquity (about $7^{\circ}$ ) is observed between the maximum of density of [001]-axes and the lineation. For this sample, three thin sections in the $X Z$ plane were 
68

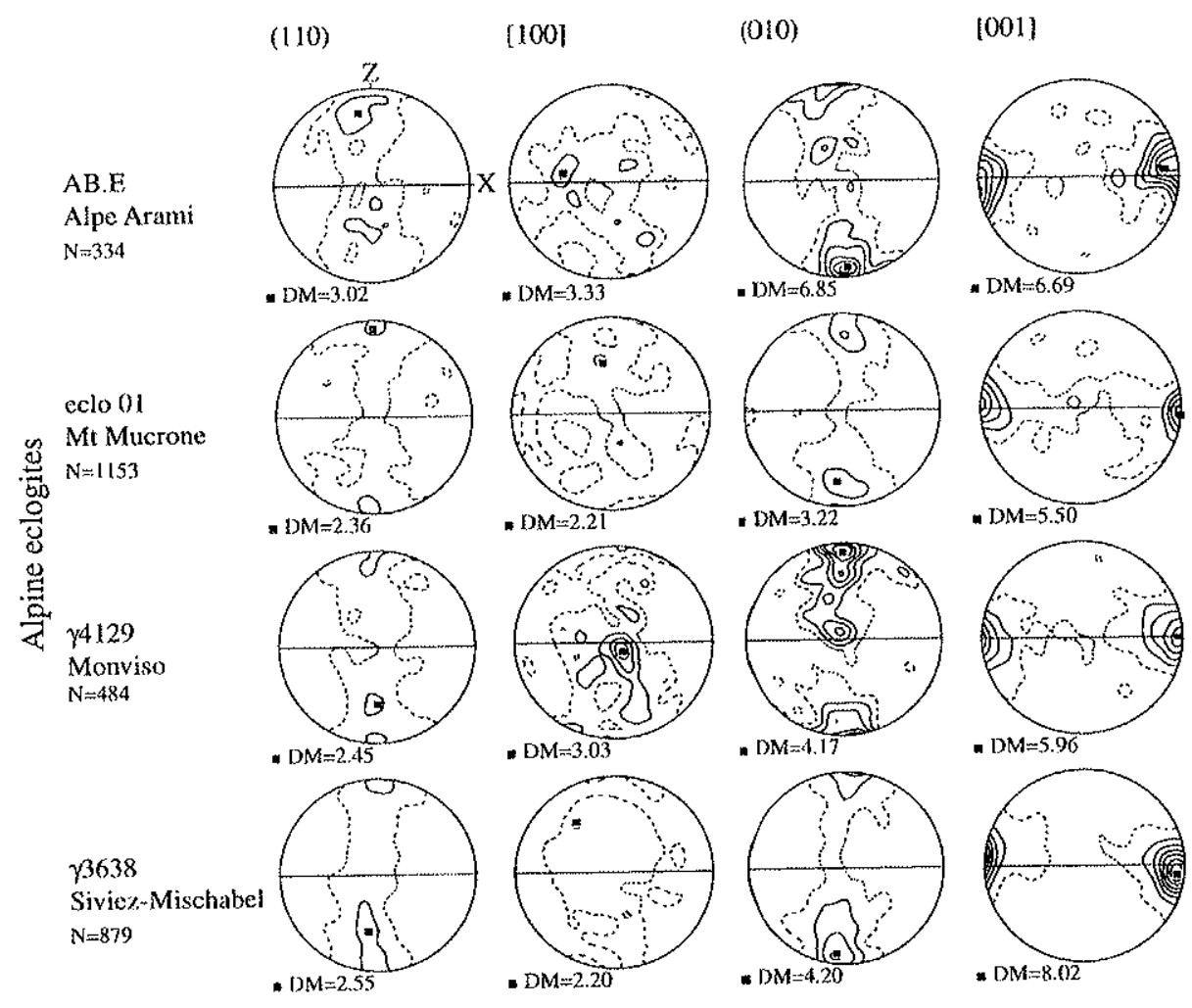

Fig. 3. Omphacite LPO of Alpine eclogites measured using EBSD technique. Equal area projection, lower hemisphere. Contours $1,2,3 \% \ldots$ by $1 \%$ area. Foliation ( $X Y$ plane; full line) is vertical and lineation $(X)$ is horizontal in this plane. $N$ : number of measurements. DM: maximum density.

manually measured on a 5 -axis universal stage mounted on an optical microscope (Fig. 4). The LPO measured from EBSD technique and from a 5- axis universal stage are very similar. Especially, we observe for both techniques an obliquity between the maximum concentration of [001]-axes and the line-

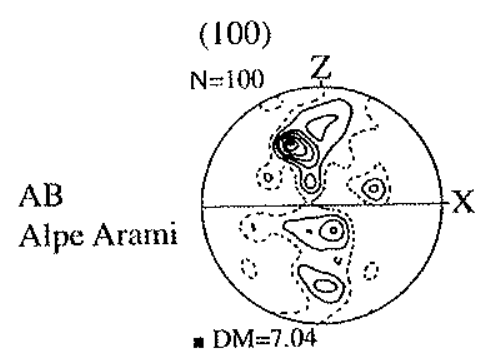

(010)

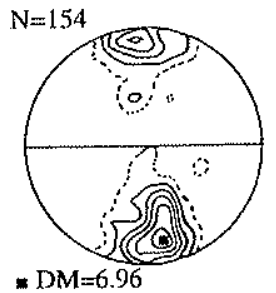

[001]

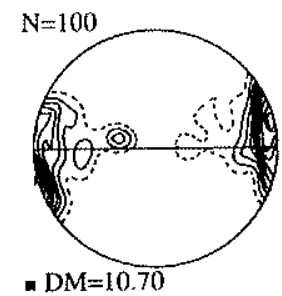

Fig. 4. Omphacite L.PO of Alpe Arami eclogite measured using a 5-axes universal stage. Equal area projection, lower hemisphere. Contours 1,2 , $3 \%$. by $1 \%$ area. Foliation ( $X Y$ plane; full line) is vertical and lineation $(X)$ is horizontal in this plane. $N$ : number of measurements. DM: maximum density. 


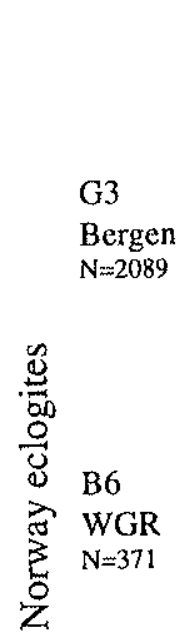

(110)

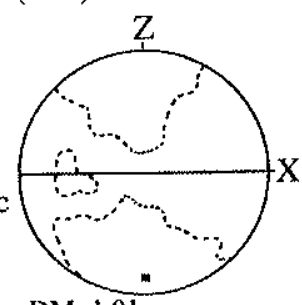

[100]

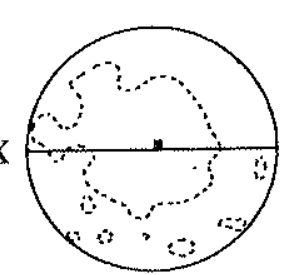

- $\mathrm{DM}=1.92$
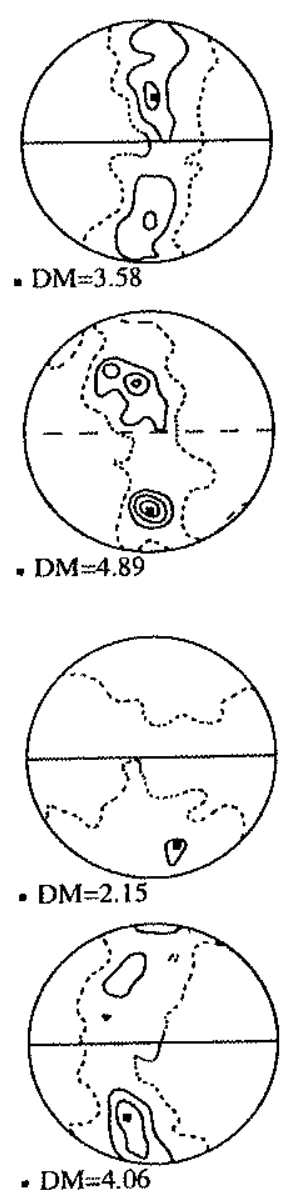

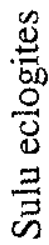

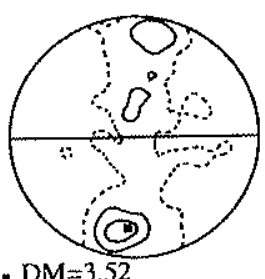

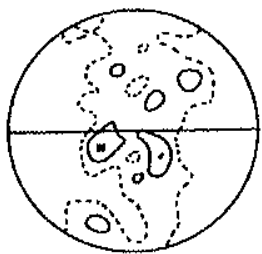

. $\mathrm{DM}=3.14$
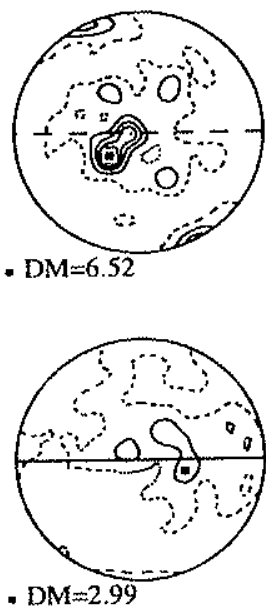

- $\mathrm{DM}=3.45$

- DM=4.07

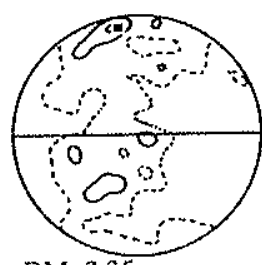

- $\mathrm{DM}=3.35$

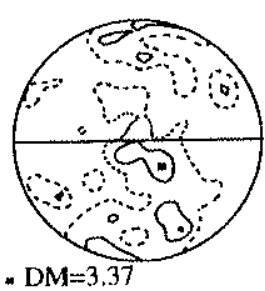

(010)
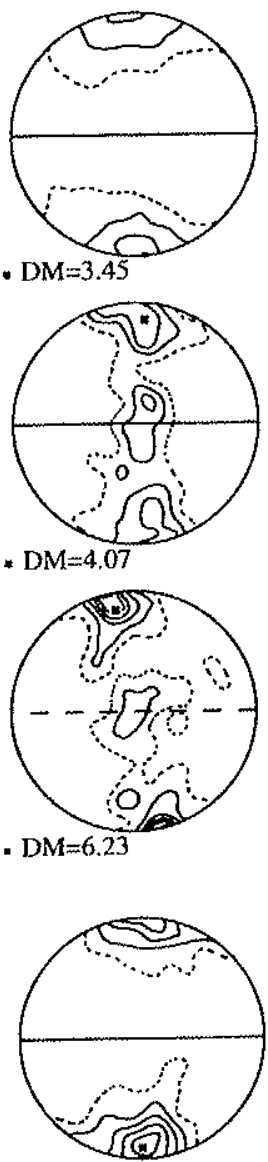

- $\mathrm{DM}=5.69$

[001]

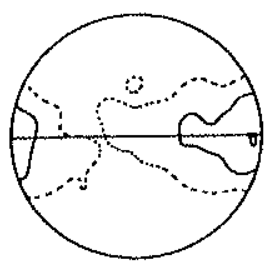

- $D M=3.07$

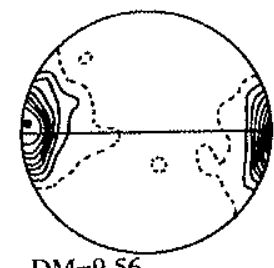

- $\mathrm{DM}=9.56$
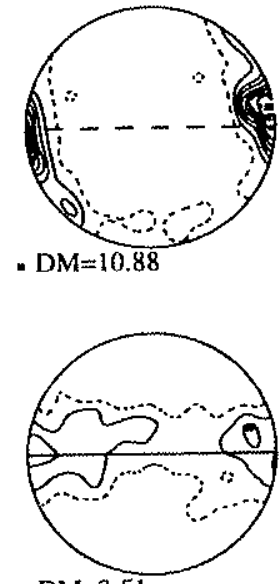

- $\mathrm{DM}=3.51$

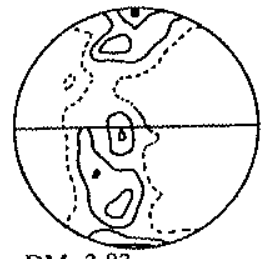

- $D M=3.83$

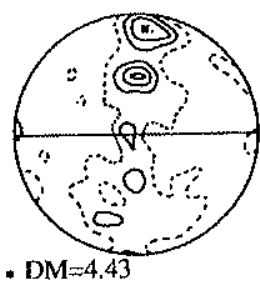

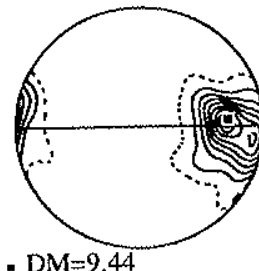

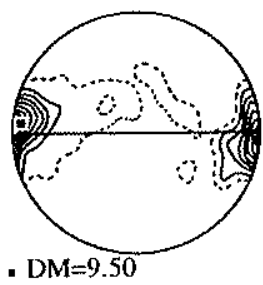

Fig. S. Omphacite L.PO of Norway and Gourma eclogite samples. EBSD measurements. Equal area projection, lower hemisphere. Contours 1, 2, $3 \%$ by $1 \%$ area. Foliation ( $X Y$ plane; full line) is vertical and lineation $(X)$ is horizontal is this plane. $N$ : number of measurements. DM: maximum density. 
ation. Discrepancies between LPO patterns may be related partly to lower precision of measurement derived from U-stage optical technique (which is expected to be about $5^{\circ}$ ) relative to the $\mathrm{EBSD}$ technim que $\left(<1^{\circ}\right.$; Mainprice et al., 1993; Krieger Lassen, 1996). Moreover, the higher concentration of omphacite LPOs derived from universal stage measurements may be due to grain selection. Indeed, due to the monoclinic symmetry of omphacite crystals, only the grains showing a cleavage plane, such as $\{110\}$, can be measured at the universal stage.

Samples eclo 01, $\gamma 4129, \gamma 3638$ (Fig. 3), B6, Norv1, S509 and SL50 (Fig. 5) are characterized by a strong [001] maximum sub-parallel to the lineation. These samples (except $\gamma 4129$ ) present a slight obliquity between the maximum of [001]-axes concentration and the lineation. The concentration of (010)poles is weaker than one [001]-axis and (010)-poles tend to form a girdle perpendicular to the lineation. Moreover, (010)-poles of samples $\gamma 4129, \mathrm{~B} 6$ and Norvl are grouped in two maxima: the strongest maximum is close to the $Z$-axis and the weakest is close to the $Y$-axis. Also, sample SL50 shows two maxima located between the $Z$ - and $Y$-axis: the strongest is close to the $Z$-axis and the weakest is at ca. $45^{\circ}$ from the $Z$-axis. Sample eclo 01 shows (010)-poles located between the $Z$ - and $Y$-axis and (110)-poles close to the $Z$-axis, whereas for the other samples the maximum of density of $(010)$-poles stands close to the $Z$-axis and the maximum of (110) is located between the $Z$ - and $Y$-axis. Sample Norvl displays [100]-axes close to $Y$ with a weaker sub-maximum at ca. $20^{\circ}$ from $Z$. However, the larger concentration of LPO for Norv1 may be due to oversampling of the largest omphacite crystals. Sample $\mathrm{S} 509$ is characterized by a clustering of [001]-axes in the foliation at ca. $20^{\circ}$ from $X$. [100]-axes show a weak maximum of density normal to the foliation. (010)-poles and (110) poles tend to form a girdle perpendicular to the lineation with a density maximum close to the $Z$-axis.

The three samples of the series $G$ (we only present G3 in Fig. 5) from Norway present similar LPO characterized by weak density maxima. The maximum of $(010)$-poles concentration is normal to the
(110)

Simple Shear

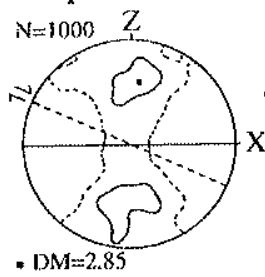

$[100]$

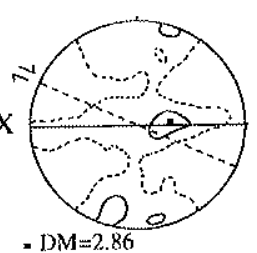

Axial Compression
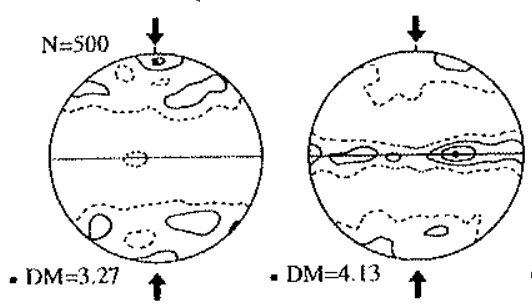

[001]

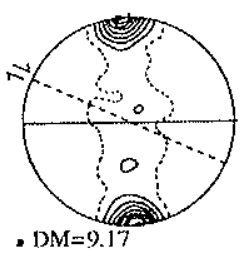

- $\mathrm{DM}=7.14$
$(010)$$$
\text { . DM=9.17 }
$$
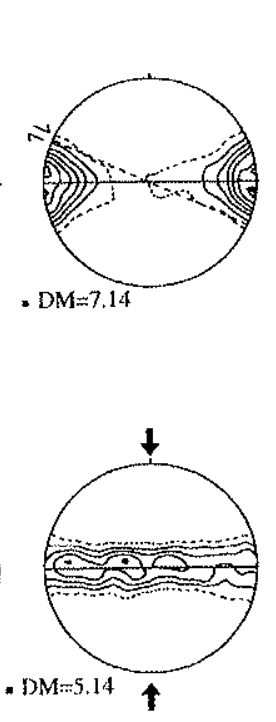

Fig. 6. Omphacite LPO simulated using an anisotropic viscoplastic self-consistent (VPSC) model in simple shear and axial compression (Bascou et al., 2001). These LPOs are developed for an equivalent strain of 1 . Equal area projection, lower hemisphere. Contours $1,2,3 \%$... by I\% area. Full line: foliation $(X Y$ plane) is vertical and lineation $(X)$ is horizontal. Dotted line: shear direction $(\gamma=1.73) . N:$ Number of grains. DM: maximum density. 
foliation and the [001]-axes tend to form a girdle in the foliation plane.

Sample S522 from Gourma area (Fig. 5) is characterized by [001]-axes scattered in the foliation plane and $(010)$ poles strongly concentrated close to $Z$. (110)-poles and [100]-axes display weak preferred orientations. However, (110)-poles present a weak maximum near the normal to the foliation.

\subsection{Omphacite LPO significance}

Variations in omphacite LPO are generally related to the strain regime (Helmstaedt et al., 1972; Boundy et al., 1992; Godard and Van Roermund, 1995; Abalos, 1997). Omphacite LPO of samples AB.E, eclo 01, $\gamma 4129, \gamma 3638$, B6, Norv1, S509 and SL50 are similar to the L-type or LS-type LPO pattern defined by Helmstaedt et al. (1972) as resulting from constriction strain. On the other hand, samples $\mathrm{S} 522$ and G3 display LPO similar to the S-type or SL-type, interpreted as resulting from flattening (Helmstaed et al., 1972; Godard and Van Roermund, 1995; Abalos, 1997). The asymmetric omphacite LPO observed for samples AB.E, $\gamma 3638$ (Fig. 3) and samples B6, Norv1 and SL50 may result from a noncoaxial deformation and the obliquity between the LPO and the $X, Y$ and $Z$ structural axes could be related to the sense of shear (Bouchez et al., 1983; Mainprice and Nicolas, 1989). Asymmetric omphacite LPO were already described by Boundy et al (1992) within eclogitized metagabbro dykes from the Bergen Arc, and by Abalos (1997) who used this obliquity to deduce the sense of shear.

In plastically deformed rocks, the LPO development due to intracrystalline slip is well established. For most minerals (c.g. olivine), when one slip system is predominant during deformation, the slip direction and the slip plane tend to coincide with the flow direction and the flow plane, respectively (Mainprice and Nicolas, 1989). Thus, the strong preferred orientation of [001]-axes parallel to the lineation and $(010)$ poles perpendicular to the foliation that characterizes the omphacite LPO in naturally deformed eclogites, suggest a dominant activation of the [001] (010) slip system. However, dislocations associated with this slip system have rarely been observed in naturally deformed omphacite. The dominant slip systems identified from TEM observations are $1 / 2\langle 110\rangle\{110\}$, [001] $\{110\}$ and [001] (100) (Van Roermund and
Boland, 1981; Van Roermund, 1983; Buatier et al., 1991; Godard and Van Roermund, 1995).

In order to better understand the deformation mechanisms that could have produced the omphacite LPO, we compared the LPO of naturally deformed omphacite with those simulated by numerical models (Bascou et al., 2001). In polycrystal plasticity models, like the anisotropic viscoplastic self-consistent model (VPSC) developed by Lebensohn and Tomé (1993) and applied to mantle rocks by Tommasi et al. (2000), the LPO evolution is directly related to the slip systems activity. Fig. 6 displays some modeled omphacite LPO developed in simple shear and axial compression. The relative strength (Critical Resolved Shear Stresses) of the various omphacite slip systems (Table 2) are derived from naturally deformed ompha cites TEM observations of dislocations (lowest CRSS values have been affected to those systems whose dislocations are the most frequently observed).

Simulated LPO display general characteristics similar to those observed in the LPO measured in naturally deformed eclogites. In particular, modeled omphacite LPO developed in simple shear deformation $(\gamma=1.73)$ reproduces well LPO observed for

Table 2

Slip systems data used to sirnulate the omphacite deformation (Bascou et al., 2001)

\begin{tabular}{ll}
\hline Slip system & CRSS $^{\mathrm{a}}$ \\
\hline$[001](100)$ & 1 \\
{$[001](110)$} & 1 \\
{$[001](1 \tilde{1} 0)$} & 1 \\
{$[1 \overline{1} 0](110)$} & 1 \\
{$[110](1 \overline{1} 0)$} & 1 \\
{$[001](010)$} & 8 \\
{$[1 \overline{1} 2](110)$} & 8 \\
{$[112](1 \overline{10})$} & 8 \\
{$[010](100)$} & 8 \\
{$[1 \overline{1}](110)$} & 8 \\
{$[11 \overline{2}](1 \overline{10})$} & 8 \\
{$[100](010)$} & 8 \\
{$[101](010)$} & 8 \\
\hline
\end{tabular}

The various potential slip systems considered come from diopside deformation experiments (Raterron et al, 1994).

"Critical Resolved Shear Stress. For this model, lowest CRSS values have been affected to those systems whose dislocations are the most frequently observed in the TEM analyses of omphacite naturally deformed (see text). 
sample AB.E (Fig. 3). Likewise, omphacite LPO predicted to develop under axial compression reproduces well LPO observed for sample S522 (Fig. 5). Interestingly, a strong preferred orientation of the (010)-poles is developed during these simulations even when the [001] (010) slip system is not activated.

The good agreement between the omphacite LPO measured in naturally deformed eclogites and the LPO simulated using a self-consistent polycrystal plasticity model suggests that omphacite LPO may be generated by dominant slip on the $1 / 2\langle 110\rangle\{110\},[001]\{110\}$ and $[001](100)$ systems. These models may reconcile the interpretation of the measured omphacite LPO in eclogites and TEM observations of dislocations in naturally deformed omphacite. From our measurements, we propose that most of the omphacite LPOs could have developed through plastic deformation during noncoaxial strain under eclogitic conditions. These LPOs are therefore related to the tectonic history of eclogites.

\section{Eclogite seismic properties}

\subsection{Seismic properties' calculation}

Seismic velocities are calculated from the Christoffel equation (Crosson and Lin, 1971) that takes into account each single crystal elastic stiffness matrix, the crystals orientation and density. The knowledge of the single crystal elastic constants and the LPO of each rock-forming mineral allows to determine the $6 \times 6$ elastic stiffness matrix characterizing the elastic behavior of each mineral phase (Mainprice, 1990). The rock elastic stiffness matrix is computed taking into account the elastic matrix of each mineral phase according to its modal proportion in the rock. In the calculation, we only take into account the major mineral phases of eclogitic metamorphism (i.e., omphacite, garnet, and epidote). For sample SL,50 from the Sulu terrain, we also considered the contribution of quartz in the seismic properties. Seismic calculations were carried out using the single crystal elastic constants measured at room temperature and atmospheric pressure by Bhagat et al. (1992) for omphacite ( $30 \%$ diopside, $58 \%$ jadeite), Babuska et al. (1978) for garnet (40\% pyrope, $40 \%$ almandin, $20 \%$ grossular) and McSkimin et al. (1965) for quartz. For sample eclo 01 containing $10 \%$ of epidote, we used the epidote elastic constants reported by Ryzhova et al. (1966) but we assumed this mineral as randomly oriented.

The omphacite single crystal seismic properties are presented in Fig. 7. The maximum P-wave velocities $(9.37 \mathrm{~km} / \mathrm{s})$ is at ca. $30^{\circ}$ from the [001] direction which is also a direction of fast propagation $(9.0 \mathrm{~km} /$ s). A girdle of lower velocity contains the (010)-pole. The P-wave anisotropy $(\mathrm{AVp})$ defined as $100 \times[\mathrm{Vp}$ $\left.\left.\max -V_{p} \min \right) /\left(\left(V_{p} \max +V_{p} \min \right) / 2\right)\right]$ is rather high $(20.4 \%)$ for the omphacite. The S-wave anisotropy is

Omphacite single crystal

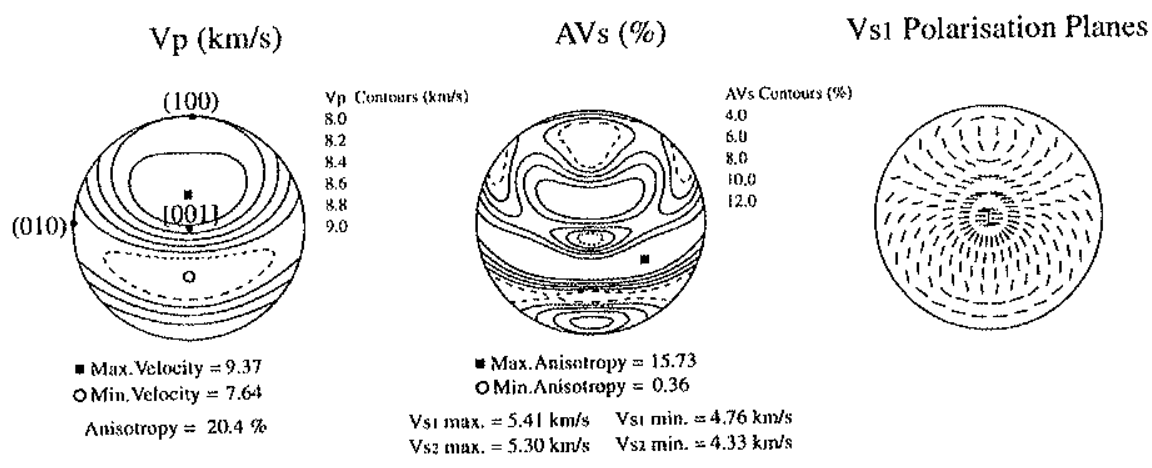

Fig. 7. Seismic properties of the omphacite single crystal. Equal area projection, lower hemisphere. 
defined for each propagation direction as $100 \times$ $\left.\left[\mathrm{Vs}_{1}-\mathrm{Vs}_{2}\right) /\left(\left(\mathrm{Vs}_{1}+\mathrm{Vs}_{2}\right) / 2\right)\right]$. The S-wave anisotropy is characterized by a complex pattern with three zones of high anisotropy $(>10 \%)$ containing the $(010)$-pole and [001]-axis. The orientation of the fast S wave polarization plane has rather complex relationship with the crystallographic axis.

\subsection{Eclogite seismic properties}

The seismic properties of the selected eclogites are summarized in Table 3 and the 3D results are shown in equal area projection (Fig. 8). The P-wave velocity patterns of eclogite samples are rather similar. The fast $\mathrm{P}$-wave velocity $(\mathrm{Vp} \max$ ) ranges from 8.51 to $8.75 \mathrm{~km} / \mathrm{s}$ and its propagation direction is generally close to the $X$-axis. The low velocity ( $\mathrm{Vp}$ $\min$ ) ranges from 8.39 to $8.62 \mathrm{~km} / \mathrm{s}$ and is roughly in a direction close to the $Z$ structural axis. The direction of $V p$ max and $V p$ min are directly related to the omphacite single crystal properties and the observed LPO. The [001]-axis (a fast velocity direction) is indeed preferentially oriented close to $X$ and the (010)-pole (a low velocity direction) is statistically oriented close to $Z$. The P-wave anisotropy is weak, generally less than $3 \%$.

The S-wave anisotropy is also very weak (less than $2 \%$ ) and characterized by complex patterns. However, most of the samples (excepted S522) show directions of highest anisotropy concentrated in four zones at $45^{\circ}$ between $X, Y$ and $Z$. Although the orientation of the fast S-wave polarization plane depends strongly on the orientation of the incoming S-wave with respect to the structural fabric, polarization planes tend to be parallel to the foliation.

For sample SL50, we calculated the seismic properties of omphacite aggregate (100\% omphacite) and velocities calculation, ignoring the contribution of quartz ( $75 \%$ omphacite, $25 \%$ garnet; Table 3). Despite a high seismic anisotropy of omphacite single crystal and a significant omphacite LPO, the seismic anisotropy of omphacite aggregate is very weak $(A V p=1.90 \%$ and $A V s \max =2.52 \%)$. The contribution of garnet $(25 \%)$ increases the $\mathrm{P}$ - and $\mathrm{S}$-waves velocities but reduces the overall seismic anisotropy $(\mathrm{AVp}=1.30 \%$ and $\mathrm{AVs} \max =1.80 \%)$.

Table 3

Seismic properties of eclogite samples

\begin{tabular}{|c|c|c|c|c|c|c|c|c|c|c|c|}
\hline Samples & $\begin{array}{l}V \mathrm{p} \max \\
(\mathrm{km} / \mathrm{s})\end{array}$ & $\begin{array}{l}\mathrm{Vp} \min \\
(\mathrm{km} / \mathrm{s})\end{array}$ & $\begin{array}{c}\mathrm{Vp} / / Z \\
(\mathrm{~km} / \mathrm{s})\end{array}$ & $\begin{array}{l}A V_{p} \\
(\%)\end{array}$ & $\begin{array}{l}\text { Vsl max } \\
(\mathrm{km} / \mathrm{s})\end{array}$ & $\begin{array}{l}\text { Vsl min } \\
(\mathrm{km} / \mathrm{s})\end{array}$ & $\begin{array}{l}\mathrm{Vs} 2 \max \\
(\mathrm{km} / \mathrm{s})\end{array}$ & $\begin{array}{l}\mathrm{Vs} 2 \text { min } \\
(\mathrm{km} / \mathrm{s})\end{array}$ & $\begin{array}{l}\text { AVs max } \\
(\%)\end{array}$ & $\begin{array}{l}\text { Omph/grt } \\
(\%)\end{array}$ & $\begin{array}{l}\text { Density } \\
\left(\mathrm{kg} / \mathrm{m}^{3}\right)\end{array}$ \\
\hline AB.E & 8.75 & 8.53 & 8.54 & 2.5 & 4.97 & 4.94 & 4.95 & 4.90 & 1.25 & $70 / 30$ & 3490 \\
\hline Eclo 01 & 8.58 & 8.47 & 8.49 & 1.3 & 4.91 & 4.88 & 4.9 & 4.87 & 0.74 & $60 / 30 / 10^{4}$ & 3497 \\
\hline$\gamma 4129$ & 8.71 & 8.54 & 8.59 & 1.9 & 4.98 & 4.93 & 4.94 & 4.92 & $\mathrm{t} .25$ & $70 / 30$ & 3490 \\
\hline$\gamma 3638$ & 8.66 & 8.56 & 8.57 & 1.2 & 4.98 & 4.93 & 4.94 & 4.91 & 1.07 & $75 / 25$ & 3462 \\
\hline G3 & 8.67 & 8.53 & 8.53 & 1.7 & 4.97 & 4.93 & 4.95 & 4.92 & 0.87 & $75 / 25$ & 3462 \\
\hline B6 & 8.72 & 8.62 & 8.63 & 1.2 & 4.99 & 4.93 & 4.95 & 4.92 & 1.41 & $60 / 40$ & 3544 \\
\hline Norv.l & 8.68 & 8.57 & 8.63 & 1.3 & 4.99 & 4.92 & 4.96 & 4.9 & 1.74 & $70 / 30$ & 3490 \\
\hline S522 & 8.73 & 8.48 & 8.50 & 2.9 & 4.97 & 4.93 & 4.95 & 4.91 & 1.18 & $75 / 25$ & 3462 \\
\hline S509 & 8.75 & 8.56 & 8.59 & 2.3 & 5 & 4.92 & 4.94 & 4.9 & 1.66 & $70 / 30$ & 3490 \\
\hline SL50 & 8.51 & 8.39 & 8.43 & 1.4 & 4.94 & 4.87 & 4.91 & 4.84 & 2.02 & $70 / 20 / 10^{b}$ & 3368 \\
\hline SL50 & 8.68 & 8.56 & 8.61 & 1.3 & 5.00 & 4.92 & 4.96 & 4.90 & 1.80 & $75 / 25$ & 3462 \\
\hline SL50 & 8.61 & 8.45 & 8.52 & 1.9 & 5.00 & 4.89 & 4.95 & 4.86 & 2.52 & $100(\mathrm{omph})$ & 3327 \\
\hline
\end{tabular}

$\mathrm{Vp} / / Z$ : P-wave velocity normal to the foliation; $A V \mathrm{p}$ : P-wave anisotropy; omph/grt: modal proportion of omphacite and garnet used for the calculation. Calculations are performed using the Voigt average. For sample SL50, also are calculated the seismic properties ignoring the contribution of quartz (75\% omphacite, $25 \%$ garnet) and the seismic properties of omphacite aggregate (100\% omphacite).

a Isotropic epidote $(10 \%)$ has been taken into account to calculate the seismic properties.

${ }^{b}$ Quartz $(10 \%)$ has been taken into account to calculate the seismic properties. 
74

J. Bascou et al. / Tectonophysics 342 (2001) $61-80$

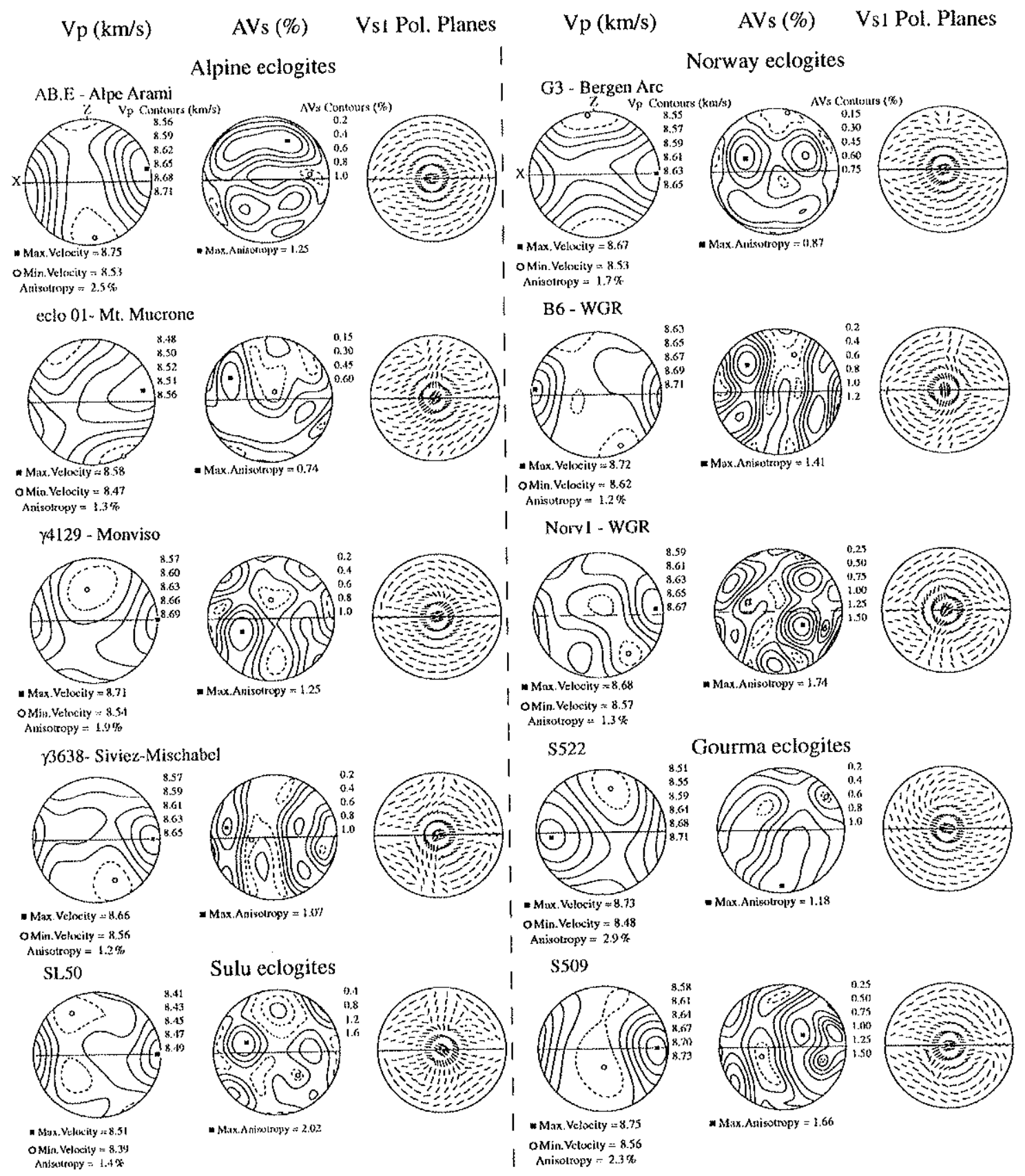

Fig. 8. Seismic properties of eclogite samples. Equal area projection in the structural reference frame $X, Y, Z$, (lower hemisphere).

The effect of quartz is to decrease the P- and Swaves velocities and slightly increase the $P$ - and $S$ wave anisotropies. The average seismic properties and the corresponding elastic constants of the 10 selected samples have been calculated (Fig. 9 and Table 4). This mean sample is almost isotropic, Pwave anisotropy is $1.4 \%$ and $\mathrm{S}$-wave anisotropy is less than $1 \%$. 


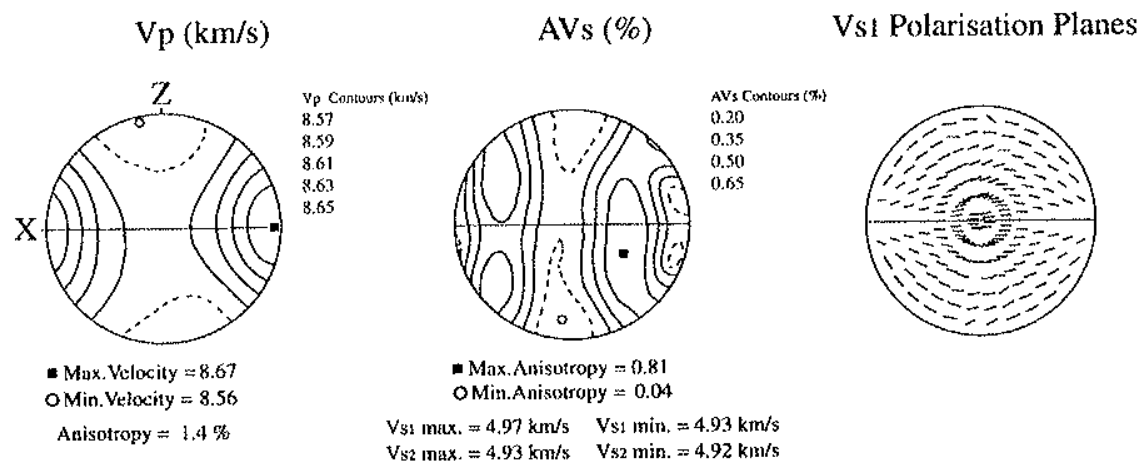

Fig. 9. Average seismic properties from the 10 eclogite samples studied in this work. Equal area projection in the structural reference frame $X, X$, $Z$, (lower hemisphere).

\subsection{Comparison between calculated and measured eclogite seismic velocities}

In their compilation of laboratory measurements in continental crustal rocks, Christensen and Mooney (1995) have highlighted the narrow range of $P$-wave velocity variation in eclogite facies rocks compared to others major metamorphic rocks. For these authors,

Table 4

Elastic constants (Cij) of the average of the 10 eclogite samples

\begin{tabular}{lc}
\hline Modulus & $\mathrm{Cij}(\mathrm{GPa})$ \\
\hline $\mathrm{C}_{14}$ & 254.57 \\
$\mathrm{C}_{12}$ & 86.80 \\
$\mathrm{C}_{13}$ & 86.83 \\
$\mathrm{C}_{14}$ & -0.16 \\
$\mathrm{C}_{15}$ & 0.12 \\
$\mathrm{C}_{16}$ & -0.30 \\
$\mathrm{C}_{22}$ & 261.43 \\
$\mathrm{C}_{23}$ & 87.77 \\
$\mathrm{C}_{24}$ & 0.37 \\
$\mathrm{C}_{25}$ & 0.01 \\
$\mathrm{C}_{26}$ & -0.11 \\
$\mathrm{C}_{33}$ & 256.07 \\
$\mathrm{C}_{34}$ & 0.07 \\
$\mathrm{C}_{35}$ & 0.05 \\
$\mathrm{C}_{36}$ & -0.08 \\
$\mathrm{C}_{44}$ & 84.70 \\
$\mathrm{C}_{45}$ & -0.02 \\
$\mathrm{C}_{46}$ & -0.02 \\
$\mathrm{C}_{55}$ & 84.29 \\
$\mathrm{C}_{56}$ & -0.11 \\
$\mathrm{C}_{66}$ & 84.31 \\
\hline & \\
\hline & \\
\hline
\end{tabular}

Density of this mean aggregate of eclogite: $d=3487 \mathrm{~kg} / \mathrm{m}^{3}$. mean $\mathbf{P}$-wave velocities in eclogites range between 7.9 and $8.5 \mathrm{~km} / \mathrm{s}$ at pressure corresponding to a depth of $20 \mathrm{~km}$. Compared to these measured velocities, our calculated P-wave velocities are slightly faster, around $8.6 \mathrm{~km} / \mathrm{s}$. As for the P-waves, the average calculated S-wave velocities (around $4.9 \mathrm{~km} / \mathrm{s}$ ) are higher than seismic velocities, which are measured around 4.5 $\mathrm{km} / \mathrm{s}$ by Kern et al. (1999) and by Manghnani et al. (1974). Such discrepancy may be related to the presence of minor phases, grains boundaries, microcracks, and to alteration of the main minerals whose effects are not taken into account in the calculations, and may affect velocity measurements. Compositional layering may also induce significant differences between calculations and measurements (Mauler et al., 2000). In addition, we calculated velocities with the Voigt average that usually gives an upper bound for scismic velocities (Crosson and Lin, 1971; Main price and Humbert, 1994). Sample G3 is interesting since direct laboratory measurements were performed by Fountain et al. (1994) on samples collected in the same area. The calculated mean P-wave velocity for this sample is $8.6 \mathrm{~km} / \mathrm{s}$, close to the fastest velocities, about $8.5 \mathrm{~km} / \mathrm{s}$, measured at $600 \mathrm{MPa}$ confining pressure in the eclogite from this locality (Fountain et al., 1994). Both calculated and measured Vp anisotropy are weak, respectively, about $2 \%$ and $3 \%$ in average. Moreover, calculated and measured $P_{\text {. }}$ wave velocities display roughly the same anisotropy pattern characterized by fast velocities parallel to the lineation, and low velocities normal to the foliation (Manghnani et al., 1974; Fountain et al., 1994; Kern et al., 1999; Mauler et al., 2000). This suggests that, in 
eclogite, the $\mathbf{P}$-wave velocity pattern is primarily controlled by omphacite LPO.

\section{Discussion}

Although the primary goal of this paper is to characterize the 3D seismic properties of eclogite rocks, a potential use of these data is to discuss the detectability of eclogite bodies within the crust and the mantle. Our calculations show that eclogites are systematically quasi isotropic. This absence of anisotropy implies that eclogites are poor candidates to generate any detectable shear wave splitting that could be used to indirectly detect eclogites bodies. Although the nondetection of a geophysical signal (here the splitting of shear wave ) is always hard to interpret in a field experiment, eclogite bodies are characterized by high density, high seismic velocities and very small seismic anisotropies. Since upper mantle rocks are generally much more anisotropic, this isotropy is the main criterion that may distinguish peridotite bodies from eclogites.

On the basis of geothermal and seismic considerations, possible eclogite/peridotite contact at the base of the continental crust has been suggested by several authors (e.g. Furlong and Fountain, 1986; Griffin and O'Reilly, 1987). Moreover, eclogite layers, as relicts of subduction zones, may be preserved within the crust or the mantle. Preservation of these layers depends on the protolith composition and on the thermal gradient. If large eclogite layers escape from the thermal reactivation, the interface eclogite/crustal rocks could generate bright seismic reflectors that might be misinterpreted as a Moho discontinuity.

In order to quantify the reflectivity of such eclogites in contact with crustal or mantle rocks, we present simple geometric models, taking into account the seismic properties issued from our calculations. We evaluate the reflectivity of simple lithological interfaces between eclogite and various lithologies (Table 5). The reflection coefficient (Rc) is calculated for a seismic wave arriving at vertical incidence on a horizontal interface. For this simplest case, a simple relation allows to calculate the reflection coefficient: $\mathrm{Rc}=\left[\mathrm{Vp}(/ / Z)_{1} \rho_{1}-\mathrm{Vp}(/ / Z)_{2} \rho_{2}\right] /\left[\mathrm{Vp}(/ / Z)_{1} \rho_{1}+\mathrm{Vp}(/ /\right.$ $Z)_{2} \rho_{2}$ ]. To evaluate the influence of seismic anisotropy, we determined in a first calculation the reflec-
Table 5

Absolute reflection coefficients $|\mathrm{Rc}|$ calculated from anisotropic $\mathrm{P}$ wave velocity and from isotropic $P_{-}$wave velocity

\begin{tabular}{lll}
\hline Interfaces & $\begin{array}{l}\mid \text { Rc| coefficient } \\
\text { for the anisotropic } \\
\text { medium }\end{array}$ & $\begin{array}{l}\mid \text { Re| coefficient } \\
\text { for the isotropic } \\
\text { medium }\end{array}$ \\
\hline Eclo/gneiss $^{2}$ & 0.30 & 0.30 \\
Eclo/kinzigite $^{1}$ & 0.28 & 0.26 \\
Eclo/magmatic gabbro $^{2}$ & 0.19 & 0.20 \\
Eclo/diorite $^{3}$ & 0.20 & 0.20 \\
Eclo/stronalite $^{2}$ & 0.14 & 0.14 \\
Eclo/mean crust $^{3}$ & 0.26 & 0.25 \\
Eclo/peridotite $^{4}$ & 0.06 & 0.04 \\
& & 0.2 \\
\hline Mean crust/peridotite & 0.2 &
\end{tabular}

The P-wave propagation is assumed to be vertical and the foliation horizontal. For eclogite (eclo), $\mathrm{Vp}$ is the average of velocities normal to foliation. In the anisotropic case $V p=8.56 \mathrm{~km} / \mathrm{s}$, and in the isotropic case $V_{p}=8.6 \mathrm{~km} / \mathrm{s}$. References for the others rocks: ${ }^{1}$ Barnol and Mairprice (1993a); ${ }^{2}$ Barruol et al (1992); ${ }^{3}$ Barruol and Mainprice (1993b); ${ }^{4}$ Vauchez and Garrido (2001).

tion coefficient, taking into account the anisotropic seismic properties of the rocks, and in a second calculation, the isotropic properties of the rocks. In the anisotropic case, Rc calculation is carried out using the $\mathrm{P}$-wave velocity in a direction nomal to the foliation. The seismic velocities of typical crustal lithologies (gneiss, kinzigite, gabbro, diorite and stronalite) were taken from the literature (Barruol et al., 1992; Barruol and Mainprice, 1993a,b). The "mean crust" (plagioclase $35 \%$, quartz $15 \%$, biotite $7 \%$, clinopyroxene $8 \%$, amphibole $15 \%$, K-feldspar $20 \%$ (isotropic)) corresponds to the average crustal composition given by Anderson (1989). We also investigated the reflectivity of an eclogite body embedded within the mantle. The seismic properties of this upper mantle rock correspond to those of a continental lherzolite sampled in the Ronda massif (Vauchez and Garrido, 2001). We selected this lherzolite sample on its typical porphyroclastic texture and LPO and on its modal composition ( $65 \%$ olivine, $20 \%$ orthopyr oxene, $10 \%$ clinopyroxene and $2 \%$ spinel). Seismic $\mathrm{P}_{\text {m }}$ wave properties of this peridotite are characterized by a maximum velocity $(8.55 \mathrm{~km} / \mathrm{s})$ parallel to the lineation, a minimum velocity $(8.09 \mathrm{~km} / \mathrm{s})$ normal to the foliation and by a P-wave anisotropy of $5.5 \%$. We summarize in Table 5 the calculated $\mathrm{Rc}$ for the various interfaces. The eclogite/crustal rocks interfaces as well 
as the peridotite/"mean crust" interface systematically display very high reflection coefficient (higher than 0.1 ). This strong reflectivity is primarily due to the density contrast between eclogite (density of $3487 \mathrm{~kg}$ / $\mathrm{m}^{3}$ on average) or peridotite (density of $3310 \mathrm{~kg} / \mathrm{m}^{3}$ ) and the crustal rocks (mean density of $2700 \mathrm{~kg} / \mathrm{m}^{3}$ ). Reflectivity of the eclogite/kinzigite interface as well as eclogite/"main crust"/interface is slightly higher when the seismic anisotropy of the rocks is taken into account. This is due to the fact that these rock types are characterized by high velocities parallel to the foliation and by lower velocities for directions at high angle from the foliation. Therefore, in the isotropic case, the velocity along the $Z$ structural directions is higher than in the anisotropic case, and the Rc slightly lower. On the other hand, the eclogite/peridotite interface is characterized by a much weaker reflection coefficient $(R c=0.06)$. Such reflection magnitude could be almost impossible to detect, particularly at a large depth by seismic reflection techniques. This interface becomes even less reflective when the manthe seismic anisotropy is not taken into account. Such difference between an anisotropic $(\mathrm{Rc}=0.06)$ and isotropic medium $(\mathrm{Rc}=0.04)$ suggests that the eclogite/ "upper mantle" reflectivity could be sensitive to the direction of the seismic wave propagation.

The main result of these simple calculations is that an eclogite body embedded in the crust would generate very strong seismic reflections, which could help to identify eclogite bodies but which may be misinterpreted in terms of Moho discontinuity. On the other hand, our calculations show that an eclogite body within the upper mantle would generate weak seismic reflection and might therefore remain almost invisible to vertical seismic reflection techniques. Moreover, the $\mathrm{Vp} / \mathrm{Vs}$ ratio and the corresponding Poisson ratio $\sigma$ (Christensen, 1996) calculated for eclogite $\left((\mathrm{Vp} / \mathrm{Vs})_{\text {iso }}=1.74\right)$ and for the Ronda lherzolite $\left((\mathrm{Vp} / \mathrm{Vs})_{\text {iso }}=1.71\right)$ are very close and therefore not discriminatory.

\section{Conclusion}

Although the studied eclogites come from orogenic domains of contrasted age and geodynamic evolution, garnet and omphacite L.PO patterns display similar main characteristics. Garnet appears to be almost randomly oriented, whereas omphacite develops strong LPO characterized by the [001] axes concentrated sub-parallel to the lineation and the $(010)$-poles roughly normal to the foliation. We suggest that these L.POs formed in relation with the deformation of eclogites through dislocation creep. This statement is supported by a numerical model result, which shows that omphacite lattice-preferred orientation can develop through plastic deformation by dominant activation of $1 / 2\langle 110\rangle\{110\},[001](110)$ and [001] (100) slip systems, in agreement with TEM observations of naturally deformed omphacite. LPO of omphacite may therefore help to constrain the tectonic processes active during the high-pressure deformation of eclogites.

Seismic properties of eclogites are mostly governed by omphacite LPO. As variations of these LPO in our dataset are rather limited, the resulting seismic properties are almost similar. Although seismic anisotropy of P-waves is weak, the fast propagation is generally parallel to the rock lineation and the low velocity propagation is normal to the foliation. For $\mathrm{P}$-waves, the relationship between seismic properties and the LPO is straightforward: the fast propagation direction is associated to the concentration of [001]-axes parallel to the lineation, and the slow propagation direction is associated to a concentration of $(010)$-poles perpendicular to the foliation. The $\mathrm{P}$. and $S$-wave anisotropies are very weak, less than $2 \%$. The $\mathrm{S}$-wave maximum polarization anisotropy is preferentially concentrated at $45^{\circ}$ between the $X, Y$ and $Z$-structural axes. Orientation of the fast $S$ wave polarization plane is poorly correlated with the structural framework but tends to be parallel to the foliation. The velocity patterns and the anisotropy magnitude are in rather good agreement with laboratory-derived seismic velocities. Average $\mathrm{P}$-wave velocities $(8.6 \mathrm{~km} / \mathrm{s})$ and $\mathrm{S}$-wave velocities $(4.9 \mathrm{~km} /$ s) are similar to the highest velocities measured in eclogites. Part of the difference between calculated and measured velocitics may be related to minor mineral phases and microfracturing, which are not taken into account in our calculation.

Finally, estimation of reflection coefficient highlights the fact that an eclogite body within the upper mantle would be difficult to detect by seismic reflection techniques, whereas eclogite bodies embedded within the crust would generate very strong seismic 
reflections. The eclogite isotropy might be a distinctive parameter since peridotites are characterized by a large seismic anisotropy, whereas the intrinsic seismic anisotropy of eclogite is usually very weak.

\section{Acknowledgements}

We thank R. Caby, B. Ildefonse, M. Faure and L. Labrousse for providing the eclogite samples. Thanks to C. Nevado who made tens of wonderful thin sections and EBSD polishing that allowed this study. R. Caby and A. Tommasi are gratefully acknowledged for fruitful discussions. We thank A. Mauler and an anonymous reviewer for constructive comments on the manuscript. This work benefited from a grant from CNRS/INSU program "Intérieur de la Terre, Exhu" mation des roches profondes"; contribution INSU no. 282. The crystal orientation measurements were made using the Laboratoire de Tectonophysique EBSD/ SEM system funded by grants from CNRS/INSU, Université Montpellier II, the NSF project \#EAR9526840 "Anatomy of an Archean craton" and ISTEEM. J.B. benefited from a PhD fellowship from the CAPES-Brazil.

\section{References}

Abalos, B., 1997. Omphacite fabric variation in the Cabo Ortegal eclogite (NW Spain): relationship with strain symmetry during high-pressure deformation. J. Struct. Geol. 19, $621 \cdots 637$.

Adams, B.L., Wright, S.I., Kunze, K., 1993. Orientation imaging: the emergence of a new microscopy. Metall. Trans. 24A, $819-831$.

Andersen, T.B., 1998. Extensional tectonics in the Caledonides of southern Norway, an overyiew. Tectonophysics 285, 333-- 351.

Anderson, D.L.., 1989. Theory of the Earth. Ed. Blackwell, Oxford.

Austrheim, H., 1987. Eclogitization of the lower crustal gramulites by fluid migration through shear zones. Earth Planet. Sci. Lett. $81,22\}-232$.

Austrheim, H., 1991. Eclogite formation and dynamics of crustal roots under continental collision zones. Terra Nova 3, 492-499.

Austrheim, H., Griffin, W.L., 1985. Shear deformation and eclogite formation within granulite facies anorthosites of the Bergen Arcs, western Norway. Chem. Geol. 50, 267-281.

Babuska, V., 1972. Elasticity and anisotropy of dunite and bronzitite. J. Geophys, Res. 77, 6955-6965.

Babuska, V., Fiala, J., Kumazawa, M., Ohno, l., 1978. Elastic properties of garnet solid-solution series. Phys. Earth Planet. Inter. $16,157-176$.

Barruol, G., Mainprice, D., 1993a. 3D seismic velocities calculated from L.POs and reflectivity of a lower crustal section ----example of the Val Sesia (Ivrea Zone, Northern Italy). Geophys. J. Int. $1\lfloor 5,1169 \ldots 1188$.

Barruol, G., Mainprice, D., 1993b. A quantitative evaluation of the contribution of crustal rocks to the shear wave splitting of teleseismic SKS waves. Phys. Earth Planet. Inter. 78, $281 \div 300$.

Barnol, G., Mainprice, D., Kern, H., Saint Blanquat, M., Compte, P., 1992. 3D seismic study of a ductile shear zone from kaboratory and petrofabric data (Saint Barthélemy Massif, Northern Pyrénées, France). Terra Nova 4, 63-76.

Bascou, J., Tommasi, A., Mainprice, D., 2001. Plastic deformation and development of clinopyroxene lattice preferred orientations in eclogites. J. Struct. Geol. (in press).

Ben Ismaïl, W., Mainprice, D., 1998. An olivine fabric database: an overview of upper mantle fabrics and seismic anisotropy. Tectonophysics $296,145-157$.

Bhagat, S.S., Bass, J.D., Smyth, J.R., 1992. Single-crystal elastic properties of omphacite-- $\mathrm{C} 2 / \mathrm{c}$ by Brillouin spectroscopy. $\mathrm{J}$. Geophys. Res. 97, 6843-6848.

Bouchez, J.L., Nicolas, A., Lister, G., 1983. Fabric asymmetry and shear sense in movement zones. Geol. Rundsch. 72, 401-419.

Boundy, T.M., Fountain, D.M., Austrheim, H., 1992. Structural development and petrofabrics of eclogite facies shear zones, Bergen Arcs, western Norway: implications for deep crustal deformational processes. J. Metamorph. Geol. 10, $127-146$.

Buatier, M., Van Roermund, H.L.M., Drury, M.R., Lardeaux, J.M., 1991. Deformation and recrystallization mechanisms in naturally deformed omphacites from the Sesia-Lanzo zone; geophysical consequences. Tectonophysics 195, 11-27.

Butler, R.W.H., 1986. Thrust tectonics, deep structure and crustal stbduction in the Alps and Himalayas. J. Geol. Soc. London $143,857 \cdots 873$.

Caby, R., 1994. Precambrian coesite from northem Mali: first record and implications for plate tectonics in the trans-Saharan segment of the Pan-African belt. Eur. J. Mineral. 6, $235 \ldots 244$.

Caby, R., Kienast, J.R., Saliot, P., 1978. Structure, metamorphisme et modèle d'évolution tectonique des Alpes occidentales. Rev. Geogr. Phys. Geol. Dyn. 20, 307-...322.

Christensen, N.I., 1996. Poisson's ratio and crustal seismology. J. Geophys. Res. 101, 3139 $\cdots 3156$.

Christensen, N.X., Mooney, W.D., 1995. Seismic velocity structure and composition of the continental crust: a global review. J. Geophys. Res. 100, $9761 \ldots 9788$.

Clark, J.R., Appleman, D.E., Papike, J.J., 1969. Crystal-chemical characterization of clinopyroxenes based on eight new structure refinements. Mineral. Soc. Am., Spec. Pap. 2, 31-50.

Compagnoni, R., Dal Piaz, G.Y., Hunziker, J.C., Gosso, G., Lombardo, B., Williams, P.F., 1977. The Sesia Lanzo zone: a slice of continental crust with alpine high pressure -.- low temperature assemblage in the Western Italien Alps. Rend. Soc. Ital. Mineral. Petrol. 33, 281-334.

Crosson, R.S., Lin, J.W., 1971. Voigt and Reuss prediction of anisotropic elasticity of dunite. J. Geophys. Res. 76, 570-578.

Dingley, D.J., Field, D.P., 1997. Electron backscatter diffraction and orientation imaging microscopy. Mater. Sci. Technol. 13, $69-78$.

Ernst, W.G., 1977. Mineralogic study of eclogitic rocks from Alpe 
Arami, Lepontine Alps, southern Switzerland. J. Petrol. 18, $371-398$.

Faure, M., Lin, W., Le Breton, N., 2001. Where is the North China South China block boundary in eastern China? Geology 29 , $119 \cdots 122$.

Fountain, D.M., Boundy, T.M., Austrheim, H., Rey, P., 1994. Ectogite-facies shear zones - deep crustal reflectors? Tectonophysics $232,411 \cdots 424$.

Furlong, K.P., Fountain, D.M., 1986. Continental crust underplatting: thermal considerations and seismic-petrologic consequences. J. Geophys. Res. 91, 8285-8294.

Godard, G., Van Roermund, H.L.M., 1995. Deformation-induced clinopyroxene from eclogites. J. Stnuct. Geol. 17, 1425-1443.

Griffin, W.L., O'Reilly, S.Y., 1987. Is the continental Moho the crust-mantle boundary? Geology 15, 241 -244.

Heinrich, C.A., 1986. Eclogite facies regional metamorphism of hydrous mafic rocks in the Central Alpine Adula Nappe. J. Petrol. 27, 123 $\cdots 154$

Helmstaedt, H., Anderson, O.L., Gavasci, A.T., 1972. Petrofabric studies of eclogite, spinel-..websterite, and spinel--lherzolite xenoliths from kimberlite-bearing breccia pipes in southeastern Utah and northeastern Arizona. J. Geophys. Res. 77, 4350-4365.

Kern, H., Gao, S., Jin, Z., Popp, T., Jin, S., 1999. Petrophysical studies on rocks from the Dabie ultrahigh-pressure (UKP) metamorphic belt, Central China: implications for the composition and delamination of the lower crust. Tectonophysics 301 , $191-215$.

Krieger Lassen, N.C., 1996. The relative precision of crystal orientations measured from electron backscattering patterns. $J$. Microse. $181,72 \sim 81$.

Krogh, E.J., 1982. Metamorphic evolution deduced from mineral inclusions and compositional zoning in garnets from Norwegian country-rock eclogites. Lithos $15,305-321$.

Lardeaux, J.M., Gosso, G., Kienast, J.R., Lombardo, B., 1982. Relations entre le métamorphisme et la déformation dans la zone de Sesia -. Lanzo (Alpes occidentales) et le problème de l'éclogitisation de la croutte continentale. Bull. Soc. Geol. Fr. 24 , $793-800$.

Latabscher, H., 1990. The problem of the Moho in the Alps. Tectonophysics $182,9-20$.

Lebensohn, R.A., Tomé, C.N., 1993. A self-consistent anisotropic approach for the simulation of plastic deformation and texture development of polycrystais: application to zirconion alloys. Acta Metall. Mater. 41, $2611 \ldots 2624$.

Lloyd, G.E., Schmidt, N.H., Mainprice, D., Prior, D.J., 1991. Crystallographic textures. Mineral. Mag. 55, $331-345$.

Mainprice, D., 1990. A FORTRAN program to calculate seismic anisotropy from the lattice preferred orientation of minerals. Comput. Geosci. 16, 385-393.

Mainprice, D., Humbert, M., 1994. Methods of calculating petrophysical properties from lattice preferred orientation data. Surv. Geophys. $15,575-592$.

Mainprice, D., Nicolas, A., 1989. Development of shape and lattice preferred orientations: application to the seismic anisotropy of the lower crust. J. Struct. Geol. 11, 175 $\cdots 189$.

Mainprice, D., Lloyd, G., Casey, M., 1993. Individual orientation measurements in quartz polycrystals: advantages and limitations for texture and petrophysical property determinations. J. Struct. Geol. 15, 1169 1187 .

Manghnani, M.H., Ramananantoandro, R., Clark Jr., S.P., 1974. Compressional and shear wave velocities in granulite facies rocks and eclogites to 10 kbar. J. Geophys. Res. 79, 54275446 .

Manler, A., Kunze, K., Burg, J.P., Philippot, P., 1998. Identification of EBSD patterns in a monoclinic solid-state solution series: example of omphacite. Mater. Sci. Forum 275, 705-710.

Mauler, A., Burlini, L., Kunze, K., Philippot, P., Burg, J.P., 2000. Pwave anisotropy in eclogites and relationship to the omphacite crystallographic fabric. Phys. Chem. Earth. 25, 119-126.

McSkimin, H.J., Anreatch, J.R., Thurston, R.N., 1965. Elastic moduli of quartz versus hydrostatic pressure at $25^{\circ}$ and $-195.8^{\circ} \mathrm{C}$ J. Appl. Phys. 36, 1624-1632.

Messiga, B., Kienast, J.R., Rebay, G., Riccardi, M.P., Tribuzzio, R., 1999. Cr-rich magnesiochloritoid eclogites from the Monviso ophiolites (Western Alps, Italy). J. Metamorph. Geol. 17, 287-299.

Möckel, J.R., 1969. Structural petrology of the garnet-peridotite of Alpe Arami (Ticino, Switzerland). Leidsche Geol. Meded. 42, $61-130$.

Nicolas, A., Christensen, N.I., 1987. Formation of anisotropy in upper mantle peridotites -... a review. In: Fuchs, K., Froidevaux, C. (Eds.), Composition, Structure and Dynamics of the Lithosphere-Asthenosphere System. Am. Geophys. Un., Washington, DC, pp. $111 \cdots 123$.

Nicolas, A., Boudier, F., Boullier, A.M., 1973. Mechanism of flow in naturally and experimentally deformed peridotites. Am. J. Sci. 273, $853-876$.

Nicolas, A., Polino, R., Hirn, A., Nicolich, R, 1990. ECORS--CROP traverse and the deep structure of the western Alps: a synthesis. Mem. Soc. Geol. Fr. 156, 15-27.

Philippot, P., Kienast, J.R., 1989. Chemical-microstructural changes in eclogitic shear zones, Monviso (Western Alps), as indicators of strain history, mechanisms and scales of mass transfer. Lithos 23 , $179-200$.

Raterron, P., Doukhan, N., Jaoul, O., Doukhan, J.C., 1994. High temperature deformation of diopside IV: predominance of $\{110\}$ glide above $1000{ }^{\circ} \mathrm{C}$. Phys. Earth Planet. Inter. 82, $209 \ldots 222$.

Rubie, D.C., 1984. A thermal -..tectonic model for high-pressure metamorphism and deformation in the Sesia Zone, Western Alps. J. Geol. 92, 21 - 36.

Ryzhova, T.V., Aleksandrov, K.S., Korobkova, V.M., 1966. The elastic properties of rock-forming minerals V: additional data on sillicates. Izv. Earth Phys. 2, 63--65.

Schmidt, N.H., Olesen, N.Ø., 1989. Computer-aided determination of crystal-lattice orientation from electron-channeling patterns in the SEM. Can. Mineral. 27, 15--22.

Thélin, P., Sartori, M., Lengeler, R., Schaerer, J.P., 1990. Eclogites of Paleozoic or early Alpine age in the basement of the Penninic Siviez--Mischabel nappe, Wallis, Switzerland. Lithos 25, $71-88$.

Tommasi, A., Mainprice, D., Canova, G., Chastel, Y., 2000. Viscoplastic self-consistent and equilibrium-based modeling of olivine 
lattice preferred orientations: implications for upper mantle seismic anisotropy. J. Geophys. Res. 105, 7893-7908.

Van Roermund, H.L.M., 1983. Petrofabries and microstructures of omphacites in a high temperature eclogite from the Swedish Caledonides. Bull. Mineral. 106, 709 .713.

Van Roermund, H.L.M., Boland, J.N., 1981. The dislocation substructures of naturally deformed omphacites. Tectonophysics 78 , $403-418$.

Vautchez, A., Garrido, C.J., 2001. Seismic properties of an asthenospherized lithospheric mantle: constraints from lattice pre- ferred orientations in peridotite from the Ronda Massif. Earth Planet. Sci. Lett. 192, 235-249.

Warner, M., Morgan, J., Barton, P., Morgan, P., Price, C., Jones, K., 1996. Seismic reflections from the mantle represent relict subduction zones within the continental lithosphere. Geology 24, $39-42$.

Zhang, R.Y., Hirajima, T., Banno, S., Cong, B., Liou, J.G., 1995. Petrology of ultrahigh-pressure rocks from the southern Su-Lu region, eastem China. J. Metamorph. Geol. 13, $659-675$. 


\title{
JOURNAL OF STRUGTURAL GEOLOGY
}

\section{Plastic deformation and development of clinopyroxene lattice preferred orientations in eclogites}

\author{
Jérôme Bascou ${ }^{a, b, *}$, Andréa Tommasi ${ }^{a}$, David Mainprice ${ }^{a}$ \\ "Laboratoire de Tectonophysique, UMR 5568 Université de Montpellier II and CNRS, Place E. Bataillon, F-34095 Montpellier cedex 5 , France \\ bInstituto de Geociências, Universidade de São Paulo, Rua do Lago, 562, BR-05508-080 Säo Paulo, Brazil \\ Received 20 February 2001; revised 9 August 2001; accepted 9 October 2001
}

\begin{abstract}
We use an anisotropic viscoplastic self-consistent (VPSC) model to simulate the development of omphacite lattice preferred orientations (LPOs) in response to deformation by dislocation glide. In these simulations, we consider slip systems identified either in naturally deformed omphacite or in experimentally deformed diopside. Simulated LPOs reproduce very well the characteristic omphacite LPO pattern in naturally deformed eclogites: a strong concentration of [001] axes sub-parallel to the lineation and of (010)-poles sub-perpendicular to the foliation. These models reconcile the interpretation of omphacite LPOs in eclogites and TEM observations of naturally deformed omphacite, since they show that omphacite LPOs in naturally deformed eclogites may develop by dislocation glide on $1 / 2\langle 110\rangle(110)$, $[001]\{110\}$ and $[001](100)$. We also investigate the effect of the strain regime on the omphacite LPO development. The simulations show that changes in deformation regime lead to second-order variations in omphacite LPO patterns similar to those observed in eclogites, such as an asymmetry of the LPO relative to the structural frame, a stronger concentration of the [001]-axes relative to the (010)-pole concentration, or a dispersion of $[001]$-axes in the foliation plane. This suggests that omphacite LPO patterns may carry information on the deformation regime (simple shear, transtension...) active during the high-pressure events. () 2002 Elsevier Science Ltd. All rights reserved.
\end{abstract}

Keywords: Lattice preferred orientations; Deformation; Dislocation glide

\section{Introduction}

Clinopyroxene is a major mineralogical constituent of the oceanic crust and upper mantle. Analysis of lower crustal sections (e.g. the Ivrea Zone, Northern Italy; Fountain and Salisbury, 1981; Pin and Sills, 1986) and xenoliths (Halliday et al., 1993) shows that clinopyroxene is also concentrated in mafic granulites and gabbroic intrusions of the lowermost crust. Such mafic rocks are transformed in eclogites by high- (or uttra-high) pressure metamorphism in subduction and/or collision zones, Clinopyroxene omphacite as the major and most deformable constituent of eclogites may then be a key mineral to decipher the tectonic processes active during the highpressure event.

An important effect of the plastic deformation of rocks is the development of a lattice preferred orientation (LPO) of their constituent minerals (Nicolas and Poirier, 1976). When one slip system is predominant during deformation (e,g.

\footnotetext{
* Corresponding author. Tel.: +33-4671-43602; fax: +33-467t-43603.

E-mail address: bascou@dstu.univ-montp2.fr (J. Bascou).
}

$[100](010)$ for olivine at high-temperature conditions), the preferred orientation of the slip direction and the slip plane tend to coincide with the flow direction and the flow plane, respectively (Nicolas and Poirier, 1976; Mainprice and Nicolas, 1989). Thus information on the flow regime can be deduced from the orientation of the slip systems relative to the structural frame. Particularly, in the case of a noncoaxial deformation, the obliquity between the LPO and the $X, Y$ and $Z$ structural axes $(X=$ lineation and $Z=$ normal to the foliation) allows the determination of sense of shear. The majority of LPO measurements for the clinopyroxene group in the literature have been made on omphacites from eclogites. The characteristic LPO of omphacite is marked by a strong concentration of $(010)$ poles normal to the foliation and of [001]-axes parallel to the lineation (e.g. Boundy et al., 1992; Godard and Van Roermund, 1995; Abalos, 1997; Bascou et al., 2001; Mauler et al., 2001; Pipenbreier and Stöckert, 2001). If one assumes that LPO development is controlled by glide on a single dominant slip system, this LPO suggests a dominant activation of the [001](010) slip system. However, dislocations associated with this slip system are not observed in naturally deformed omphacite. In fact, TEM observations of dislocations in 
omphacites from naturally deformed eclogites (Van Roermund and Boland, 1981; Van Roermund, 1983; Buatier et al., 1991; Godard and Van Roermund, 1995) show that dislocation creep results in dominant activation of the $1 / 2\langle 110\rangle\{1 \overline{1} 0\},\{001](110\}$ and $[001](100)$ slip systems. Based on microstructural observations, Godard and Van Roermund (1995) and Mauler et al. (2001) have proposed that activation of other deformation mechanisms, such as grain boundary migration and diffusive mass transfer or diffusion creep with concomitant anisotropic growth, may reconcile the apparent discrepancy between LPO data and TEM observations.

Deformation experiments also contribute to our under standing of the deformation of clinopyroxenes. Such experiments have been mainly performed on diopside single crystals (Avé Lallemant, 1978; Ingrin et al., 1992; Raterron et al., 1994) or polycrystalline aggregates (Boland and Tullis, 1986; Lavie, 1998; Mauler et al., 2000; Bystricky and Mackwell, 2001). These experiments show that plastic flow of diopside is essentially accommodated by three deformation mechanisms. At low temperature, high strain rate, and high stress, diopside deforms by mechanical twinning on (100) and (001) planes (e.g. Avé Lallemant, 1978). At higher temperature, plastic deformation occurs by dislocation creep or diffusion creep depending on grain size and flow stresses (Lavie, 1998; Bystricky and Mackwell, 2001). Dislocation creep accommodated by an association of dislocation glide and dynamic recrystallization by subgrain rotation and grain boundary migration is dominant in both natural clinopyroxenites (Bystricky and Mackwell, 2001) and synthetic polycrystals deformed by torsion (Mauler et al., 2000). In addition, single crystal deformation experiments at moderate and high temperatures show that plastic deformation of diopside results in dominant activation of $\{110\}$ and (100) slip systems. Between 800 and $900^{\circ} \mathrm{C},[001](100)$ is the easiest system with a flow stress on the order of $60 \mathrm{MPa}$ at laboratory strain rates, $[100](010)$ and $1 / 2\langle 110\rangle\{1 \overline{1} 0\}$ are less easily activated (flow stresses are on the order of $200 \mathrm{MPa})$, and [001] $(110\}$ systems are hard to activate (Ingrin et al., 1992). At higher temperatures (above $1000^{\circ} \mathrm{C}$ ), the activation of $1 / 2\langle 110\rangle(110\}$ slip systems is favored (Ingrin et al., 1991; Raterron et al., 1994).

Slip systems observed in omphacite and diopside are similar. However, rheological laws obtained for diopside aggregates suggest that unreasonable high stresses and/or low strain rates are needed to deform clinopyroxene-rich rocks by dislocation creep at temperatures below $700^{\circ}$. This is in contradiction to microstructural and thermobarometric data in eclogites that indicate that omphacite deforms by dislocation creep at temperatures as low as $450^{\circ} \mathrm{C}$ (e.g. Buatier et al,, 1991; Philippot and Van Roermund, 1992; Pipenbreier and Stöckert, 2001). Indeed, preliminary experimental data on synthetic jadeite poly crystals (Renner, unpublished, cited in Stöckert and Renner, 1998) show low flow stresses, in agreement with the low melting point of sodic clinopyroxenes (jadeite, omphacite) compared with diopside (Pipenbreier and Stöckert, 2001).

In order to investigate the deformation mechanisms that could produce the observed clinopyroxene LPOs, we use a viscoplastic self-consistent model (VPSC) to simulate the omphacite LPO development in response to deformation by dislocation glide. In these models, we consider that omphacite deforms by slip on those systems identified in naturally deformed eclogites or in experimentally deformed diopside. To investigate the effect of strain regime on the LPO pattern, we modeled omphacite LPO development in simple shear, axial compression, transpression and transtension. Modeled LPO patterns are then compared with omphacite LPO patterns of eclogites sampled in various orogenic domains.

\section{Naturally deformed omphacite LPO}

\subsection{Previous data on clinopyroxene LPOs}

Clinopyroxene LPOs have been, up to now, essentially measured on 5-axes universal stage (e.g. Helmstaedt et al., 1972; Van Roermund, 1983; Boundy et al., 1992; Barruol and Mainprice, 1993; Godard and Van Roermund, 1995; Abalos, 1997) and, more recently, using the electron backscattered diffraction (EBSD) technique (Bascou et al., 2001; Mauler et al., 2001; Pipenbreier and Stöckert, 2001). The most common omphacite LPO is the ' $(010)$ fabric' that is characterized by a concentration of $(010)$-poles and [001]axes perpendicular to the foliation and parallel to the lineation, respectively. Variations on the relative concentration of (010)-poles and [001]-axes in this characteristic LPO have been traditionally interpreted in terms of strain symmetry during high-pressure deformation (Helmstaedt et al., 1972; Godard and Van Roermund, 1995; Abalos, 1997). Two end-members are described: the 'L-type or constriction fabric', characterized by (010)-poles in a girdle perpendicular to the lineation and [001]-axes forming a single maximum strongly concentrated in the lineation and the 'S-type or flattening fabric', characterized by a strong (010)-poles concentration perpendicular to the foliation and [001]-axes lying in the foliation plane. These end member fabrics correspond to coaxial-deformation regimes. However, omphacite LPO patterns asymmetric to the $X, Y$ and $Z$ structural axes have also been observed in naturally deformed eclogites (Boundy et al., 1992; Abalos, 1997; Bascou et al., 2001).

The '(100) fabric' characterized by (100)-poles concentrated perpendicular to the foliation, (010)-poles close to the $Y$-axis, and [001]-axes parallel to the lineation that is common for orthopyroxene (e.g. Mockel, 1969) is rarely described for clinopyroxene. Such LPO patterns were nevertheless observed in an annealed mylonitic eclogite from the Monviso, western Alps (Philippot and Van Roermund, 1992) and in both a mylonitic pyroxenite and 
a mylonitic clinopyroxene-garnet amphibolite from the Snowbird tectonic zone, Canada (Ji et al., 1993). LPOs intermediate between the $(010)$ and the $(100)$ fabrics have also been described in eclogites (see Godard and Van Roermund, 1995; Abalos, 1997) as well as a clinopyroxene fabric characterized by [001]-axes concentrated close to the $Y$-axis (Sicgesmund et al., 1989; Ji et al., 1993).

\subsection{Measured omphacite LPOS}

We measured omphacite LPOs of 12 eclogites coming from orogenic domains of contrasting age and geodynamic evolution. The geological setting, microstructures, LPOs and seismic properties of these samples are described in detail in Bascou et al. (2001). For this study, we have selected four of these samples, which display strong and typical LPOs. These four samples (AB.E, B6, SL50, S522) are characterized by different $P-T$ conditions of eclogitization. Sample AB.E has been collected within the eclogite boudin surrounding the Alpe Arami peridotite massif in the western Alps, north of the Insubric line; pressure and temperature conditions of the eclogitic metamorphism have been estimated to be above $1.8 \mathrm{GPa}$ and $750-900^{\circ} \mathrm{C}$ (Heinrich, 1986). Eclogite B6 was sampled in the core of an eclogite boudin located in the Western Gneiss Region (western Norway), north of the Nordfjord-Sogn detachment. Sample SL50 comes from the Sulu region, castern China; the eclogitic metamorphism conditions were evaluated at ca. $700-890^{\circ} \mathrm{C}$ and above $2.8 \mathrm{GPa}$ (Zhang et al., 1995). Sample S522 is an eclogitic metasediment from the internal nappes of the Gourma area, northern Mali. Coesite relics in omphacite (Caby, 1994) indicate subduction of these rocks up to depths over $100 \mathrm{~km}$ (Jahn et al, 2001). These four samples display well-preserved eclogite facies parageneses. The most important constituent minerals are omphacite and garnet; these two mineral phases represent more than $75 \%$ of the modal content. All samples exhibit a strong foliation and lineation defined by the shape-preferred orientation of the omphacite crystals. Omphacite grain sizes vary from ca. $0.3 \mathrm{~mm}$ in sample $\mathrm{S} 522$ to ca. $4 \mathrm{~mm}$ in sample AB.E. Garnet grains are almost euhedral with grain sizes up to $2 \mathrm{~mm}$ (sample B6).

Omphacite lattice preferred orientations were measured using a scanning electron microscope (SEM) equipped with an EBSD system. The EBSD technique (e.g. Venables and Harland, 1973; Adams et al., 1993) is based on the automatic analysis of diffraction patterns (Kikuchi bands) generated in the SEM by interaction of a vertical clectron beam with a carefully polished thin section tilted to $70^{\circ}$. The Kikuchi patterns are collected on a phosphor screen, imaged by a low-light, high-resolution CDD camera, and indexed using the CHANNEL + software from HKL Technology. At each point of measurement, the full crystallographic orientation, described by the Euler angles $(\vartheta 1, \phi, \vartheta 2)$ is determined with a precision of $1^{\circ}$ (Krieger Lassen, 1996).
LPOs of the samples AB.E, B6 and S522 were measured in manual mode and SL50 in automatic mode. For the automatic acquisition, measurements are performed on a square grid with a step of the same order as the omphacite grain size of the studied sample (1 $\mathrm{mm}$ for SL50).

The measured omphacite LPOs (Fig. 1) are presented on equal area, lower hemisphere stereographic projections in the structural $(X, Y, Z)$ reference frame. Foliation ( $X Y$ plane) is vertical $\mathrm{E}-\mathrm{W}$ and the lineation ( $X$ direction) is horizontal in this plane. The fabric strength is expressed by the dimensionless texture index $J$ (Bunge, 1982). The $J$-index ranges from 1 (random LPO) to infinity (single crystal). However, in our calculations, the $J$-index has an upper bound of ca. 250 because the spherical harmonic series expansion is truncated at degree 22. All samples display typical omphacite LPO patterns characterized by a strong concentration of [001]-axes and (010)-poles parallel to the $X$-axis and normal to the $X Y$ plane, respectively. (110)-poles and $[100]$-axes are poorly oriented. (110)-poles tend nevertheless to concentrate in a girdle perpendicular to the lineation with two maxima between the $Y$ - and $Z$-axis. [100]-axes display a weak concentration close to the $Y$-axis. Besides these general features, second-order variations in the LPO pattern are observed sample to sample. Sample $\mathbf{5 2 2}$ is distinguishable from the other samples by a stronger concentration of (010)-axes normal to the foliation and a dispersion of [001]-axes in the foliation plane. Samples AB.E, B6 and SL50 are characterized by stronger fabrics; their $J$-indexes range from 6.4 (AB.E) to 7.7 (B6). Both [001] axes and (010)-poles are very concentrated and are oblique to the structural reference frame. However, in samples B6 and SLS0, the [001]-axes are about twice more concentrated than the $(010)$-poles whereas the [001] axes and $(010)$-poles in sample AB.E are characterized by similar maximum densities.

\section{Viscoplastic self-consistent modeling of omphacite LPOS}

We investigated the evolution of omphacite LPOs using the anisotropic viscoplastic self-consistent model (VPSC) developed by Molinari et al. (1987) and extended to anisotropic materials by Lebensohn and Tomé (1993). Recently, this code has been successfully applied to polycrystalline ice (Castelnau et al., 1996) and olivine (Tommasi et al., 2000).

TheVPSC model is based on two assumptions: (i) the crystals that constitute the aggregate deform uniquely by homogeneous intracrystalline slip on selected crystallographic planes (dynamic recrystallization is not taken into account), and (ii) the aggregate behavior may be calculated as an average of the crystals behavior. Locally, from grain to grain, strain and stress are heterogeneous and grains in easy glide orientations deform faster than those in hard orientations. Strain compatibility and stress equilibrium are ensured at the aggregate scale, i.e. the volume averaged 


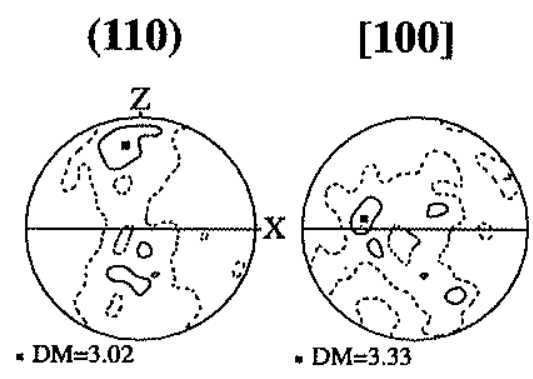

Alpe Arami eclogites, sample AB.E $\mathrm{N}=334 ; \mathrm{J}=6.45$
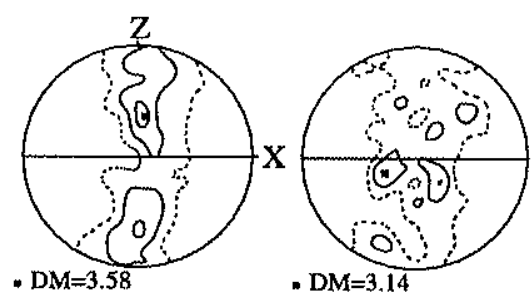

Nordfjord (WGR) eclogites, sample B6

$\mathrm{N}=371 ; \mathrm{J}=7.74$
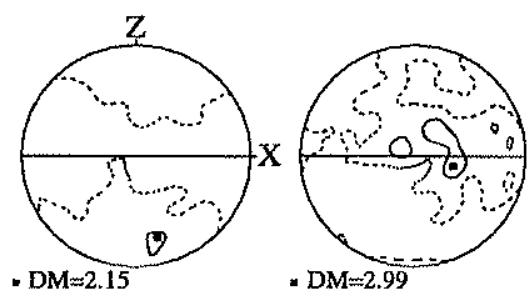

Gourma eclogites, sample S522

$\mathrm{N}=506 ; \mathrm{J}=4.50$
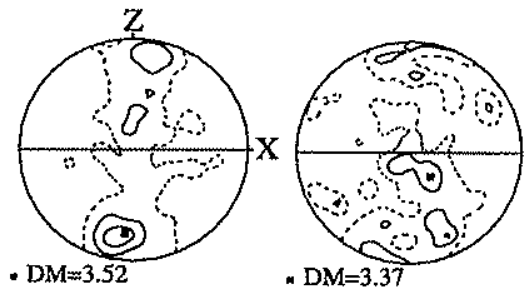

Sulu eclogites, sample SL50

$\mathrm{N}=281 ; \mathrm{J}=6.52$
(010)

[001]

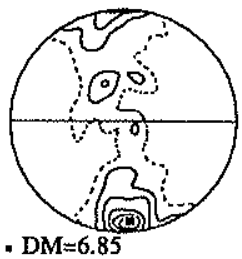

. $\mathrm{DM}=6.85$

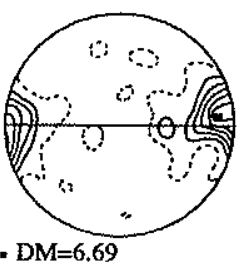

- $\mathrm{DM}=6.69$
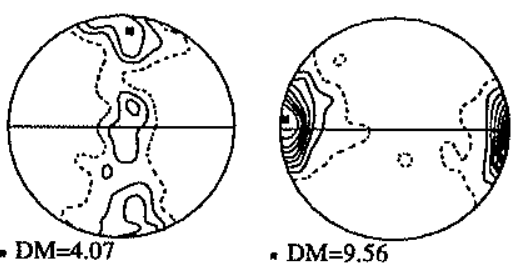

. $\mathrm{DM}=9.56$

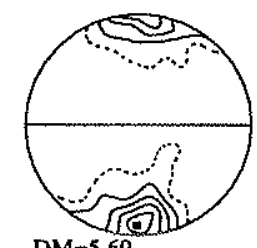

. $\mathrm{DM}=5.69$
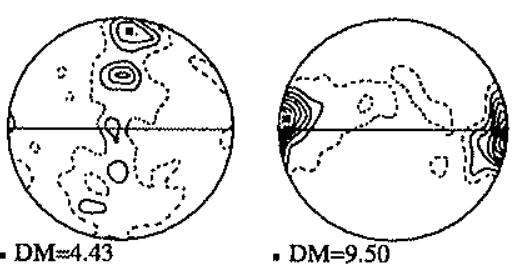

Fig. 1. Omphacite LPO measured using the EBSD technique (Bascou et al., 2001). Equal area projection, lower hemisphere. Equal area projections, lower hemisphere. Contours at $1,2,3 \% \ldots$ by $1 \%$ area. Foliation ( $X Y$ plane; full line) is vertical and lineation $(X)$ is horizontal in this plane. $N$ : number of measurements. $J$ : texture index. DM: maximum density.

stresses and strain rates $(s, \dot{\varepsilon})$ of the grains are equal to the polycrystal stress and strain rate $(\overrightarrow{\bar{\Sigma}}, \overline{\mathbf{D}})$. The interaction between the grain and the polycrystal is treated using the inclusion formalism of Eshelby (1957), where each grain is handled as an inhomogeneity within a homogeneous effective medium (HEM), which represents the polycrystal. Stresses and strain rates of the grains are thus related to the macroscopic quantities through:

$\dot{\varepsilon}_{i j}-D_{i j}=-\alpha \tilde{\mathbf{M}}_{i j k l}\left(s_{k l}-\vec{\Sigma}_{k l}\right)$

where $\tilde{\mathbf{M}}$ is the interaction tensor that depends on the rheological properties of the polycrystal and on the shape of the grains. The constant $\alpha$ is used to parameterize the 
interaction between grains and the HEM, i.e. to impose more or less stringent kinematic conditions on grains. A zero value of $\alpha$ corresponds to the Taylor (1938) model (the upper bound approach) that imposes homogeneous stress. A value of unity corresponds to the tangent VPSC model of Lebensohn and Tomé (1993), and an infinite value corresponds to the stress equilibrium model (i.e. the lower bound approach; Chastel et al., 1993).

Most models presented below have been performed using the tangent formulation $(\alpha=1)$. Yet microstructural observations in naturally deformed eclogites (e.g. Buatier et al., 1991) as well as in experimentally deformed diopside aggregates (e.g. Mauler et al,, 2000) show that deformation of clinopyrexenes in the dislocation creep regime associates dislocation glide and dynamic recrystallization by subgrain rotation and/or grain boundary migration. Thus, considering that during the deformation of omphacite-rich rocks strain compatibility is partly ensured by diffusional processes, we have also performed VPSC simulations in relaxed strain compatibility conditions $(\alpha=10)$. Since LPO patterns produced in coaxial deformation simulations with relaxed strain compatibility conditions $(\alpha=10)$ are similar to those obtained using the tangent formulation $(\alpha=1)$, we will only present LPOs for simple shear models with relaxed compatibility (Fig. 4).

For a given set of slip systems and an initial LPO, the VPSC model calculates the aggregate yield strength (or strain rate), the activity of the slip systems, and the LPO evolution in response to an imposed macroscopic deformation (or stress) history. Slip system data are presented in Table 1. In the model, slip systems of monoclinic omphacite (unit cell parameters: $a=9.54 \AA, b=8.70 \AA, c=5.25 \AA$ and $\beta=106.06^{\circ}$ (Bhagat et al., 1992)) are projected into a Cartesian reference frame. Since expcrimental constraints on the critical resolved shear stresses (CRSS) of the various slip systems of omphacite are lacking, we have investigated the effect of varying the CRSS on the LPO evolution. We

Table 1

Slip system data used in the CRSS 1 ind CRSS 2 models

\begin{tabular}{lcc}
\hline Slip systems & ${\text { CRSS }]^{2}}$ & CRSS 2 $^{2}$ \\
\hline$[001](100)$ & 1 & 1 \\
{$[001](110)$} & 10 & 1 \\
{$[001](10)$} & 10 & 1 \\
{$[110](110)$} & 3 & 1 \\
{$[110](110)$} & 3 & 1 \\
{$[100](010)$} & 3 & 8 \\
{$[001](010)$} & 8 & 8 \\
{$[112](110)$} & 10 & 8 \\
{$[112](110)$} & 10 & 8 \\
{$[010](100)$} & 10 & 8 \\
{$[112](110)$} & 10 & 8 \\
{$[112](110)$} & 10 & 8 \\
{$[101](010)$} & 10 & 8
\end{tabular}

- Critical resolved shear stresses (CRSS) are nomalized by the CRSS $_{(00]\}(100) \text {. }}$ have tested a large range of CRSS values, but since the LPO evolution is weakly dependent on small variations of the CRSS, we only present models for two CRSS sets. CRSS 1 is evaluated from experimental deformation data on diopside single crystals (Ingrin et al., 1992); the CRSS values for all systems are normalized relative to the critical resolved shear stress of the easiest [001](100) system (ca. $60 \mathrm{MPa}$ at laboratory conditions, Ingrin et al., 1992). CRSS 2 is inferred from TEM observations of dislocations in omphacite of naturally deformed eclogites. In this set, the lowest CRSS values (arbitrary equal to one) are affected in those systems whose dislocations are the most frequently observed. The stress exponent $n$ is evaluated from experimental deformation data for diopside single-crystals and polycrystals: values range between 3.3 (Avé Lallemant, 1978; Boland and Tullis, 1986), and 6.5 (Raterron and Jaoul, 1991). Most models were run with $n=3.5$, but we also performed tests with $n=5$. Since L.POs predicted in both cases are similar (with only a slightly faster LPO evolution for $n=5$ ), we only show here the results for $n=3.5$.

In the models presented below, an aggregate of 1000 (or 500) omphacite grains, initially spherical and randomly oriented, is deformed in simple shear, axial shortening, transpression and transtension. Each deformation regime is described by a constant velocity gradient tensor $L$, defined as:

$L=\left[\begin{array}{lll}0 & 1 & 0 \\ 0 & 0 & 0 \\ 0 & 0 & 0\end{array}\right], \quad L=\left[\begin{array}{ccc}1 & 0 & 0 \\ 0 & -1 & 0 \\ 0 & 0 & 0\end{array}\right]$,

$L=\left[\begin{array}{ccc}0.5 & 0 & 0 \\ 0 & -1 & 0 \\ 0 & 0 & 0.5\end{array}\right], \quad L=\left[\begin{array}{ccc}0.237 & 1 & 0 \\ 0 & -0.237 & 0 \\ 0 & 0 & 0\end{array}\right]$,

$L=\left[\begin{array}{ccc}0 & 1 & 0 \\ 0 & 0.237 & 0 \\ 0 & 0 & -0.237\end{array}\right]$

for simple shear, pure shear, axial compression, transpression and transtension simulations, respectively. Transpression and transtension are defined as a combination of simple shear and coaxial deformation. This combination is quantified by the kinematic vorticity number $(W k)$. In coaxial deformation, $W k=0$ and in simple shear $W k=1$. Our transpression and transtension models are characterized by $W k=0.9$, i.e. by predominance of the simple shear component.

In order to compare the L.PO evolution in different deformation regimes, all LPO data are displayed for an equivalent strain of one, obtained by the accumulation of 40 identical deformation steps. The equivalent strain is 


\section{VPSC models with CRSS 1}

Simple Shear $N$ $\mathrm{N}=1000 ; \mathrm{J}=5.56$
(110)

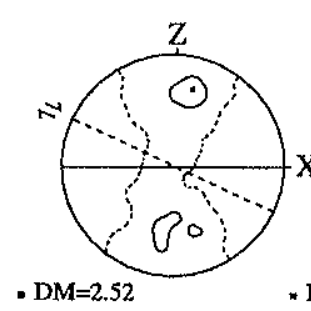

* $\mathrm{DM}=2.59$

\section{$[100]$}
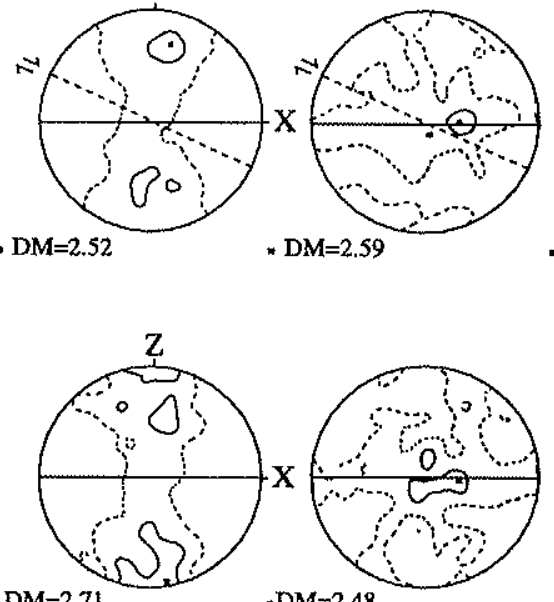

$. \mathrm{DM}=2.48$

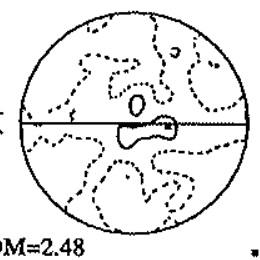

$. \mathrm{DM}=7.99$

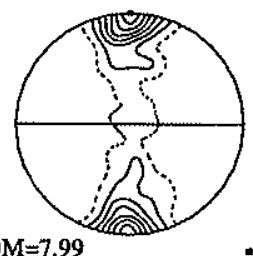

$. \mathrm{DM}=7.70$

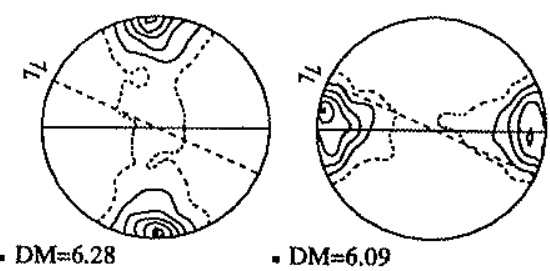

- $\mathrm{DM}=6.09$
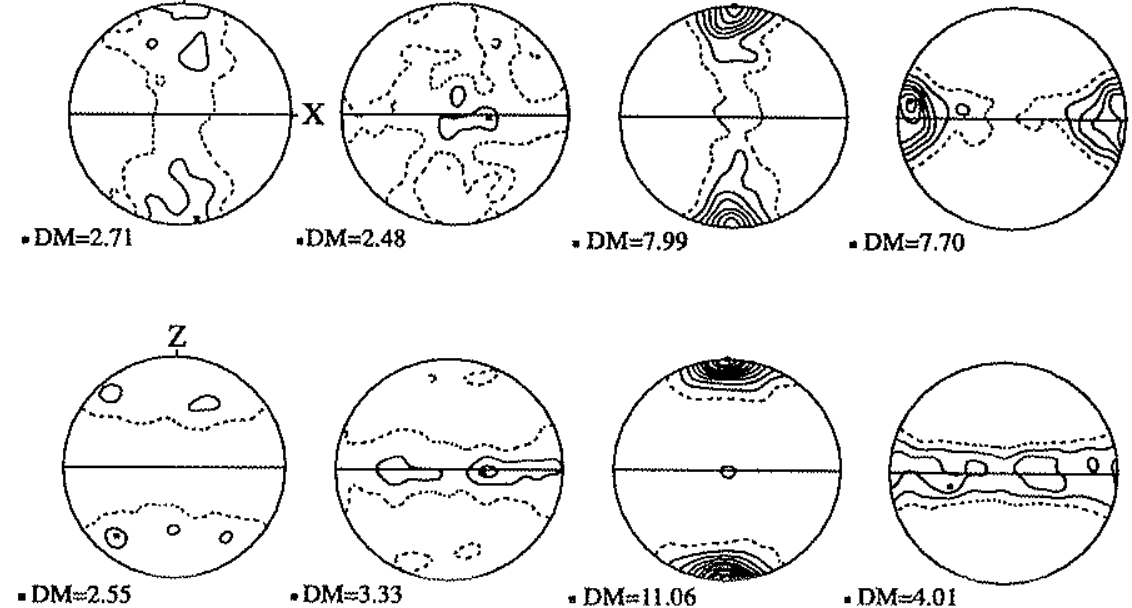

[001]

$D M=4.0$

Fig. 2. Omphacite LPO simulated in VPSC models with $\alpha=1$ and CRSS cvaluated from experimental deformation data on diopside (CRSS 1). Dextral simple shear, pure shear and axial compression at equivalent strain of one. Equal area projections, lower hernisphere. Contours at $1,2,3 \% \ldots$ by $1 \%$ area. Full line: foliation $(X Y$ plane) is vertical and lineation $(X)$ is horizontal. For the model in simple shear $(\gamma=1.73)$, dotted line marks the shear plane and the direction of shear is horizontal in this planc. $N$ : number of grains. $J$ : texture index. $D M$ : maximum density.

defined as (Molinari et al., 1987)

$\varepsilon_{\mathrm{eq}}=\int D_{\mathrm{eq}}(\tau) \mathrm{d} \tau$

where $\mathrm{d} \tau$ is the time increment of a deformation step, chosen so that each deformation step leads to a 0.025 equivalent strain for the polycrystal. The Von Mises equivalent strain rate $D_{\mathrm{eq}}$ is defined as:

$D_{\mathrm{cq}}=\left(\frac{2}{3} D_{i j} D_{i j}\right)^{1 / 2}$

Although eclogites are composed essentially of omphacite and garnet, we choose to approach the deformation of omphacite in polymineralic eclogites by simulations using $100 \%$ omphacite aggregates. This choice is based on microstructural data that suggest that garnet generally behaves as rigid inclusions during eclogite deformation, except at very high temperature (e.g. Ando et al., 1993), This hypothesis is also supported by the random crystallographic orientation of garnet in all but one of the samples studied by Bascou et al. (2001) and by the lack of correla tion between variations in the modal content of garnet and changes in the omphacite LPO. Moreover, previous VPSC simulations of the LPO evolution in two-phase systems, like olivine-menstatite (Wenk et al., 1991) and quartz-mica aggregates (Canova et al., 1992), show that the presence of a hard phase does not change fundamentally the LPO pattern of the soft matrix.

\subsection{Simple shear and pure shear}

Models in simple shear $(\gamma=1.73)$ and pure shear (Figs. 2 and 3) performed using the tangent formulation $(\alpha=1)$ generate similar LPOs characterized by strong concentrations of (010)-poles and [001]-axes perpendicular to the $X Y$-plane and parallel to the $X$-axis, respectively. The $(010)$-poles systematically display slightly stronger concentrations than the [001]-axes. (110)-poles and [100]-axes are nearly randomly oriented. However, (110)-poles tend to 


\section{VPSC models with CRSS 2}

Simple Shear $\mathrm{N}=1000 ; \mathrm{J}=7.31$
$N$
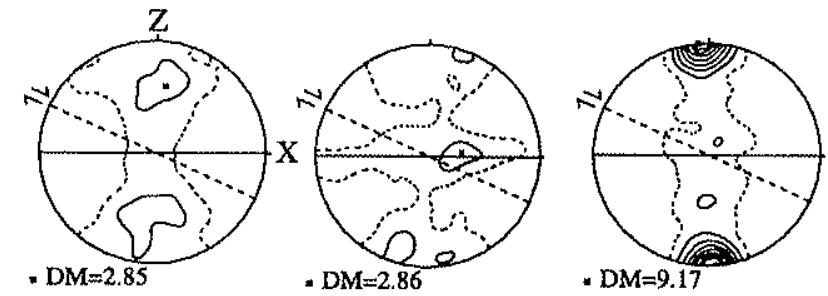

- $\mathrm{DM}=9.17$

(010)

[001]
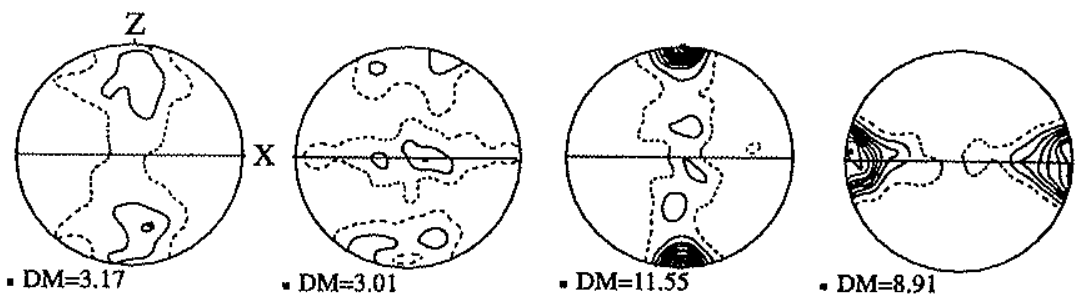

- $\mathrm{DM}=8.91$

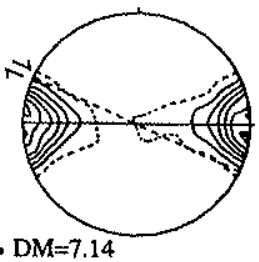

- $\mathrm{DM}=7.14$
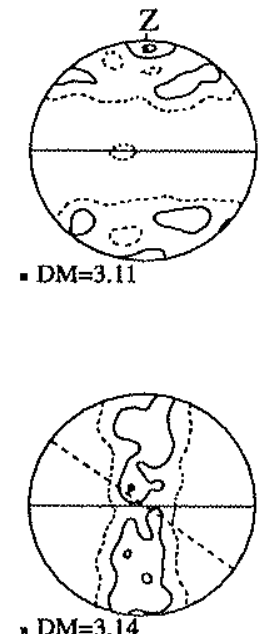

n $\mathrm{DM}=3.14$
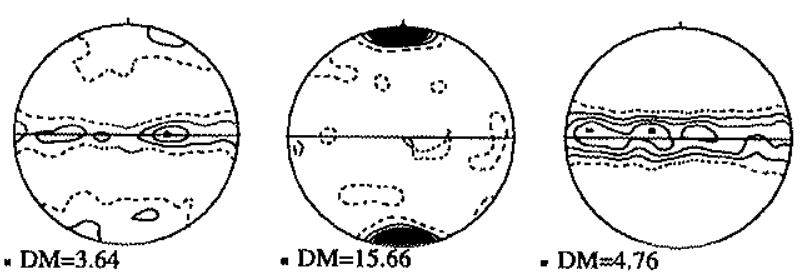

Transtension
$\mathrm{N}=500 ; \mathrm{J}=9.12$

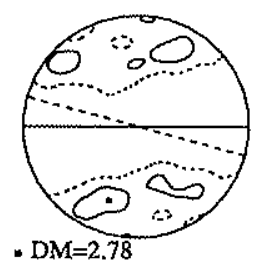

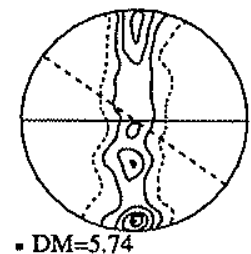

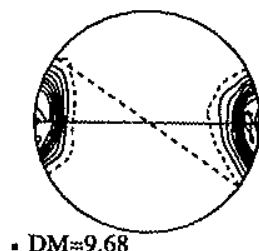

- $\mathrm{DM}=2.81$

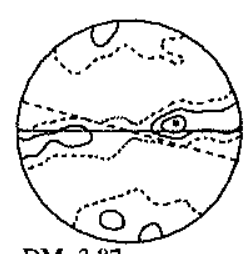

- $\mathrm{DM}=3.87$

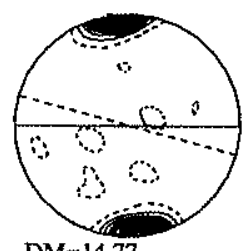

- $\mathrm{DM}=14.77$

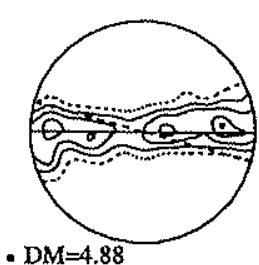

Fig. 3. Omphacite LPO simulated in VPSC models with $\alpha=1$ and with CRSS evaluated from TEM observations of dislocations in omphacites of naturally deformed eclogites (CRSS 2). LPO formed in dextral simple shear, purc shear, axial compression, transpression $(W k=0.9)$, and transtension $(W k=0.9)$ for an equivalent strain of one. Equal area projections, lower hemisphere. Contours at $1,2,3 \% \ldots$ by $1 \%$ aren. Full line: foliation $(X X$ plane $)$ is vertical and lineation $(X)$ is horizontal. Dotted line: shear plane. $N$ : Number of grains. $J$ : texture index. $D M$ : Maximum density. 


\section{VPSC models $(\alpha=10)$}

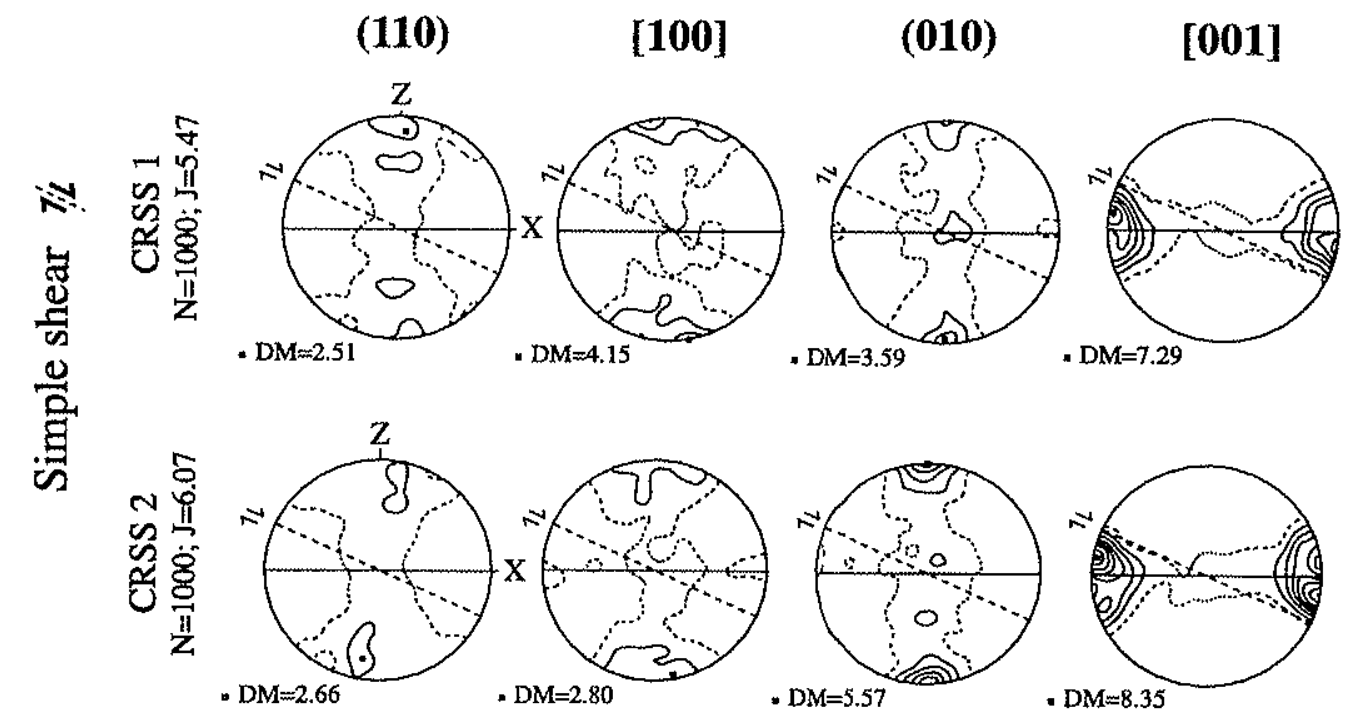

Fig. 4. Omphacite LPO developed in simple shear models with relaxed strain compatibility $(\alpha=10) . E_{\omega 4}=1(\gamma=1.73)$ and dextral sense of shear. Equal area projections, lower hemisphere. Contours at $1,2,3 \% \ldots$ by $1 \%$ aren. Full line: foliation ( $X Y$ plane) is vertical and lineation $(X)$ is horizontal. Dotted line: shear plane. $N$ : Number of grains. $J$ : texture index. DM: maximum density.

form a girdle perpendicular to the $X$-axis with a weak maximum at ca. $60^{\circ}$ to the $X Y$ plane and [100]-axes display a maximum of density close to the $Y$-axis.

Models performed using critical resolved shear stresses inferred from experimental deformation of diopside (CRSS 1) and from TEM analyses of naturally deformed omphacite (CRSS 2) produce similar LPOs, but the LPO evolution is slightly faster in CRSS 2 models. In simple shear models with relaxed strain compatibility $(\alpha=10)$, the difference between LPOs simulated using the CRSS 1 and CRSS 2 sets become more pronounced. The CRSS 1 model develops a maximum and a sub-maximum of (010)-poles close to the $Z$-axis and the $Y$-axis, respectively, whereas the CRSS 2 model develops a single (010)maximum close to the $Z$-axis (Fig. 4 ). In contrast to simulations with $\alpha=1$, the relaxed CRSS 1 model is characterized by a strong concentration of [100]-axes close to the $Z$-axis and a stronger concentration of [001]-axes relative to the (010)-poles. Finally, both simple shear models with relaxed strain compatibility develop LPO patterns asymmetric relatively to the foliation $(X Y)$ plane: the [001]-axes are intermediate between the shear direction and the $X$-axis (Fig. 4), in agreement with the imposed dextral shear.

\subsection{Axial shortening}

Models in axial compression (Figs. 2 and 3) develop LPOs that are symmetrical relative to the $X Y$ plane. (010)poles are strongly concentrated close to $Z$, the shortening direction. [001]-axes and [100]-axes are dispersed in the $X Y$ plane with a weak maximum of [100] at ca. $20^{\circ}$ from the $Y$-axis. (110)-poles are highly dispersed, but display a weak concentration close to the $Z$-axis. As in simple shear, LPOs developed using both CRSS sets are similar and CRSS 2 models produce a stronger concentration of (010)-poles close to the $Z$-axis.

\subsection{Transpression and transtension}

Models in transpression $(W k=0.9)$ produce LPO patterns similar to those of axial shortening (Fig. 3). However, in transpression, [001]-axes tend to form a girdle with two maxima at ca. $20^{\circ}$ from the $X$-axis and the $(010)$ poles display significantly higher concentrations than those developed in axial shortening. LPOs formed in transtension models $(W k=0.9)$ are similar to simple shear ones, but highly oblique to the shear plane and direction. [001]-axes are concentrated in a small circle around the lineation, at $35^{\circ}$ to the shear direction. They display the strongest concentration with a maximum density of $9.7 \%$. $(010)$-poles tend to form a girdle sub-perpendicular to the lineation with a maximum density close to the $Z$-axis. (110)-poles also form a girdle normal to the lineation but their dispersion is higher than the $(010)$-poles. [100]-axes are still more scattered.

\subsection{Slip systems activity}

Evolution of the slip systems activity with finite strain in CRSS 1 and CRSS 2 models is displayed in Fig. 5. In simple shear, both models are characterized by dominant activation of [001] systems. In CRSS 1 models, the activity of the 

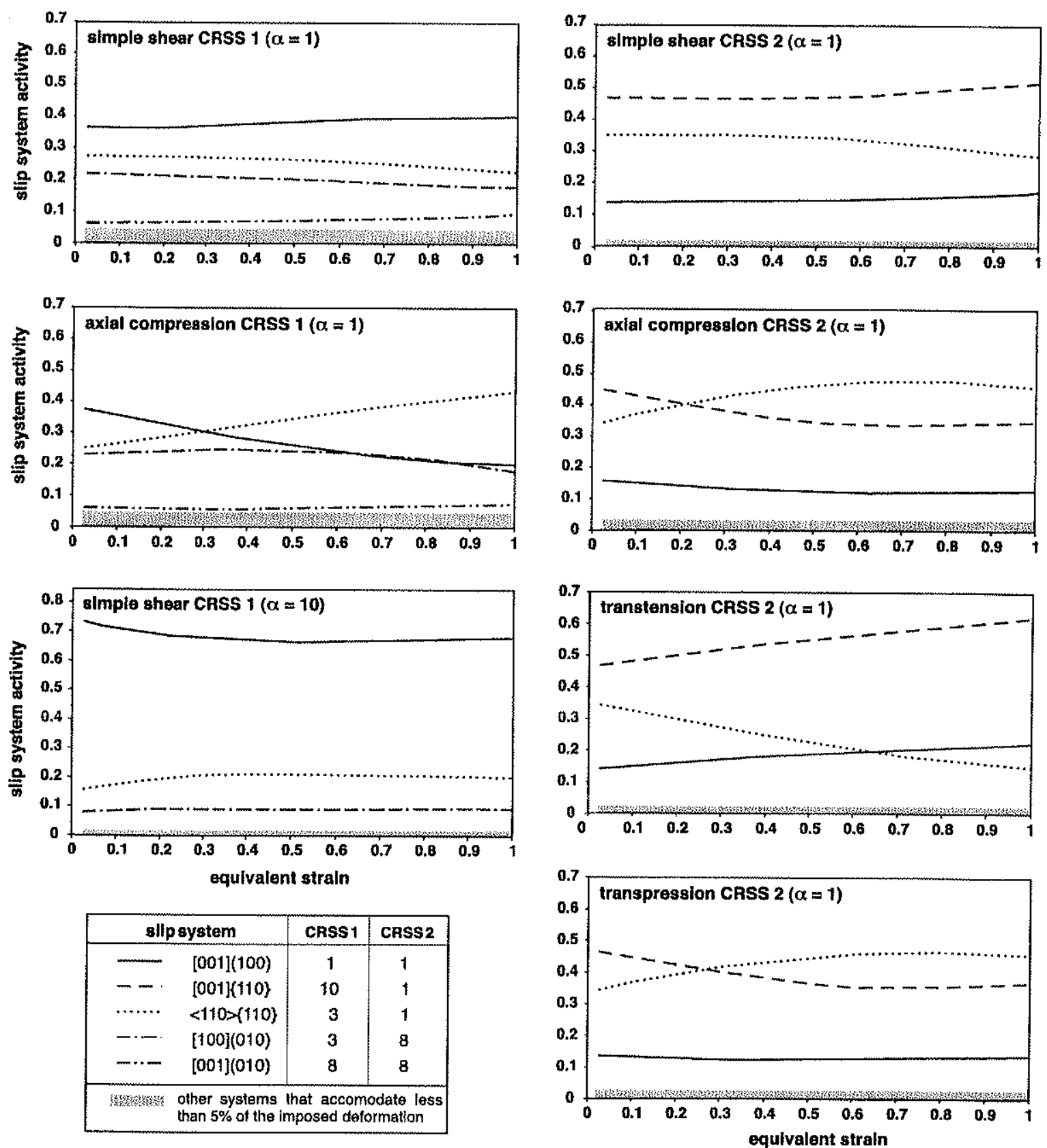

Fig. 5. Evolution of the slip systems activity with finite strain in simple shear, axial compression, transpression, or transtension models using either the CRSS or the CRSS 2 critical resolved shear stresses sets.

[001](100) system, which has the lowest CRSS value, increases with increasing strain, accommodating $40 \%$ of the deformation at an equivalent strain of one. Activity of $1 / 2\langle 110\rangle\langle 1 \overline{1} 0\}$ and $[100](010)$ decreases with increasing strain, but $1 / 2\langle 110\rangle(1 \overline{1} 0)$ displays a higher activity than $[100](010)$ even though both systems are characterized by a similar CRSS. In CRSS 2 models, the activity of the [001](110\} system increases quickly after an equivalent strain of 0.5 . This system accommodates more than $50 \%$ of the deformation at an equivalent strain of one $(\gamma=1.73)$. In general, $(110)$ systems accommodate more than $75 \%$ of the deformation. The resulting LPO is marked by a strong concentration of [001]-axes sub-parallel to the $X$-axis and by an orientation of $(010)$-poles sub-parallel to the $Z$-axis.

In axial shortening and transpression, the symmetrical 


\section{Diopside LPO in sheared gabbro}

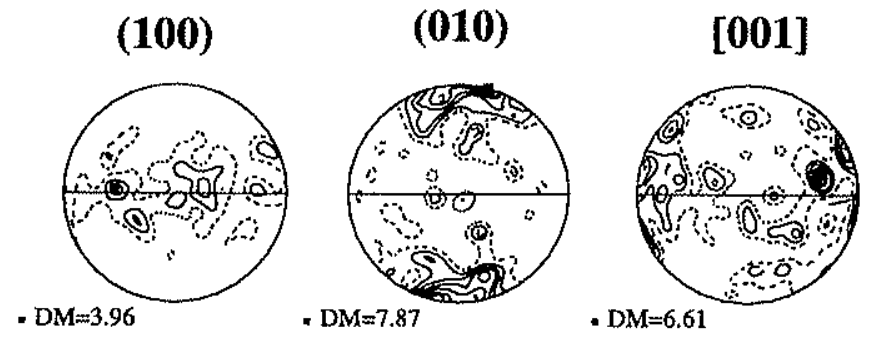

Fig. 6. Clinopyroxene LPO in a sheared gabbro from the Ivrea zone (northern ltaly; Barruol and Mainprice, 1993). U-stage data; equal area projection, lower hemisphere. Contours at 1 multiple of a uniform distribution intervals. Full line: foliation ( $X Y$ plane) is vertical and lineation ( $X$ ) is horizontal.

$1 / 2\langle 110\rangle\{1$ ĩ 0$\}$ systems are better adapted to accommodate the imposed deformation geometry. However, in CRSS 2 models, $[001](110\}$ is also activated $(0.35$ at an equivalent strain of 0.4). In transtension, as in simple shear, the [001] (110) system displays the highest activity. However, in transtension, the activity of [001](100) increases faster, leading to a higher concentration of [001]-axes than in simple shear.

Relaxation of strain compatibility in simple shear simulation using the CRSS 1 set favors the activity of the [001](100) system. This system accommodates almost $70 \%$ of the deformation (Fig. 5). The $1 / 2\langle 110\rangle\{1 \overline{1} 0\}$ and [100](010) systems accommodate 20 and $10 \%$ of the defor mation, respectively. Slip on the 'hard' $[001](010)$ is no longer required. In CRSS 2 models the activity of slip systems is similar in simulations with relaxed strain compatibility $(\alpha=10)$ or with more stringent compatibility conditions $(\alpha=1)$.

\section{Discussion}

Omphacite LPOs simulated using viscoplastic selfconsistent models reproduce well the typical omphacite LPOs of naturally deformed eclogites (Fig. 1) as well as diopside LPOs in sheared gabbros of the lower crust (Barruol and Mainprice, 1993; Fig. 6). Both CRSS 1 and CRSS 2 models develop concentrations of (010)-poles and [001]-axes perpendicular to the foliation and parallel to the lineation, respectively. LPOs modeled using the CRSS 2 set are characterized by the strongest concentration of (010)poles, even though (010) systems are not activated. Moreover, even in CRSS 1 models, [h01](010) systems accommodate less than $25 \%$ of the imposed deformation (Fig. 5). This suggests that the orientation of omphacite (010)-planes parallel to the foliation observed in eclogites is correlated to the activity of $\{110\}$ systems. During the deformation, the omphacite crystal rotates toward a position in which the resolved shear stress on the two $\{110\}$ equivalent planes will be equal and the highest. For geometrical reasons, $(\{110\}$ is bisector of $(100)$ and $(010))$, this position is reached with either the $(010)$ plane or the $(100)$ plane parallel to the foliation (Fig. 7). The orientation with the (010) plane parallel to the foliation is preferred due to the monoclinic symmetry of omphacite. Indeed, in omphacite, the angle between (110) and (110) planes is different by $90^{\circ}$ $\left(95^{\circ}\right.$ for omphacite crystals of unit cell parameters: $a=9.54 \AA ., b=8.70 \AA, c=5.25 \AA$; Fig. 7), and this results in higher resolved shear stresses on $\{110\}$ planes when the crystal is oriented with (010) parallel to the foliation. This strong relation between the crystallographic structure and the concentration of $(010)$-poles normal to the foliation is supported by the LPO predicted in a simple shear with a model crystal structure with unit cell parameters: $a=8.70 \AA, b=9.54 \AA, c=5.25 \AA$ and $(110):(\overline{1} 10) \sim 85^{\circ}$, i.e. with an inversion of $a$ and $b$ unit cell parameters relative to the omphacite crystal. In fact, this model produces a concentration of [100]-axes perpendicular to the foliation. The high activity of slip on $\{110\}$ planes (Fig. 5) may also explain the similarity of LPOs formed in the two models (CRSS 1 and CRSS 2). Although the easiest slip systems in these models differ, glide on the $\{110\}$ planes is geometrically necessary unless the strain is relaxed. Indeed, in models with relaxed strain compatibility, LPOs developed in CRSS 1 and CRSS 2 models vary.

The good agreement between measured and modeled omphacite LPOs also suggests that our simulations using pure omphacite aggregates offer a good approximation of the natural deformation of omphacite in polymineralic eclogites. Besides the excellent first-order agreement

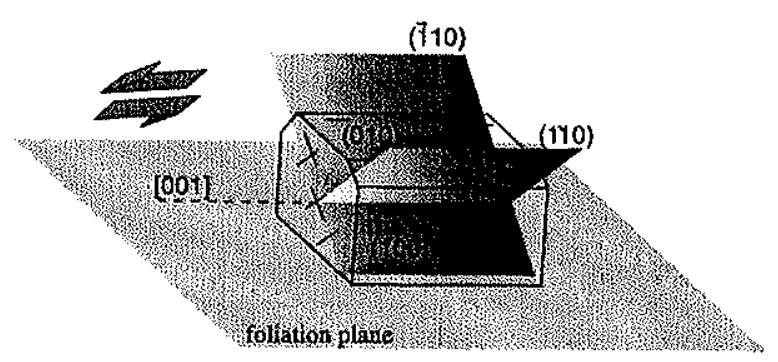

Fig. 7. Schematic diagram showing the omphacite crystal in the position in which the resolved shear stress on the two $\{110\}$ equivalent planes is the highest. Omphacite unit cell parameters: $a=9.54 \AA, b=8.70 \AA$, $c=5.25 \AA$; $(110):(\overline{1} 10)-95^{\circ}$. 
between measured and modeled clinopyroxene LPOs, we may also reproduce the different omphacite LPOs observed in naturally deformed eclogites by varying the deformation regime in the simulations. Omphacite LPOs predicted by models in simple shear and pure shear are characterized by strong (010) and [001] single maxima normal to the foliation and parallel to the lineation, respectively. A similar LPO is observed in many naturally deformed eclogites, such as AB.E (Fig. 1). Axial shortening and transpression models are characterized by a very strong concentration of $(010)$ poles perpendicular to the foliation and a girdle distribution of [001] axes in the foliation. For low amounts of pure shear $(W k=0.9)$, transpression models develop a weak maximum of [001] close to the lineation, but for higher amounts of pure shear $(W k=0.75)$ the [001]-axes maximum is rotated towards the $Y$-axis. Simulated LPOs developed in transpressive regimes with low amounts of pure shear reproduce well the LPOs of the Gourma S522 sample (Fig.1). Finally, models in transtension show that, at low proportions of pure shear relative to the simple shear component $(W k=0.9)$, both $(010)$ and [001] form single maxima, but [001]-axes develop higher concentrations than (010)-poles. Similar patterns are also observed in simple shear models with relaxed strain compatibility, but these later also develop a clear obliquity between the [001]-axes concentration and the lineation, which suggests that non-coaxial strain may produce the obliquity observed in natural samples. This LPO is the most common pattern in naturally deformed eclogites studied by Bascou et al. (2001), e.g. the Sulu (SL50) and the Western Gneiss Region (B6) samples (Fig. 1). It is interesting to note that recent tectonic studies (Krabbendam and Dewey, 1998) propose that transtension played an important role in the exhumation of ultra-high pressure rocks in the Western Gneiss Region.

\section{Conclusion}

The good agreement between omphacite LPOs measured in naturally deformed eclogites and the LPOs developed in VPSC models using various deformation regimes suggests that:

- Omphacite LPO typical of naturally deformed eclogites can be generated during plastic deformation by slip on $1 / 2\langle 110\rangle\{1 \overline{1} 0\},[001]\{110\}$ and $[001](100)$ systems. Dominant activation of these slip systems is in agreement with TEM studies in naturally deformed omphacites and high-temperature, high-pressure experimental deformation data for diopside. In addition, for omphacite, the models show that slip on $\{110\}$ planes plays a major role on the orientation of $(010)$-poles normal to the foliation. A similar effect is expected for diopside, because its unit cell parameters are similar to those of omphacite and $\{110\}$ slip systems are easily activated under moderate to high-temperature conditions.
- Second-order variations of omphacite LPO patterns observed in naturally deformed eclogites are probably related to variations in the deformation regimes active under eclogite-facies conditions. For instance, the asymmetry of omphacite LPO in samples B6 (WGR), AB.E (Alpe Arami) and SL50 (Sulu) may indicate non-coaxial strain during the eclogitic deformation. Thus LPO patterns of omphacite deformed under eclogite facies conditions may be a good tool to constrain some of the tectonic processes active during the high-pressure deformation of eclogites.

\section{Acknowledgements}

We thank R. Caby, M. Faure, and L. Labrousse for providing eclogite samples and C. Nevado for the highquality polished thin sections for the EBSD analysis. We also thank G. Barruol, M. Egydio-Silva, and A. Vauchez for helpful discussions and M. Bystricky and G. Godard for constructive reviews of the manuscript. This work benefited from funding from the CNRS/INSU program "Interieur de la Terre: Exhumation des roches profondes". Crystal orientation measurements were made using the Laboratoire de Tectonophysique EBSD/SEM system funded by grants from CNRS/INSU, Université Montpellier II, ISTEEM, and NSF project \#EAR 9526840 "Anatomy of an Archean craton". J.B. benefited from a Ph.D. fellowship from the CAPES Brazil.

\section{References}

Abalos, B., 1997. Omphacite fabric variation in the Cabo Ortegal eclogite (NW Spair): relationship with strain symmetry during high-pressure deformation. Journal of Structural Geology 19,621-637.

Adans, B.I., Wright, S.I., Kunze, K., 1993. Orientation imaging; the emergence of a new microscopy. Metallurgical Transactions 24A, 819-831.

Ando, J.I., Fujino, K., Takeshita, T., 1993. Dislocation microstructures in naturally deformed silicate garnets. Physics of the Earth and Planetary Interiors $80,105-116$

Avé Lallemant, H.G., 1978. Experimental deformation of diopside and websterite. Tectonophysics 48, 1-27.

Barruol, G., Mainprice, D., 1993. 3D seismic velocities calculated from LPOs and reflectivity of a lower crustal section-example of the Val Sesia (Ivrea Zone, Northern Italy). Geophysical Journal International $115,1169-1188$.

Bascou, J., Barruol, G., Vauchez, A., Mainprice, D., Egydio-Silva, M., 2001. EBSD-measured lattice preferred orientations and seismic properties of eclogites. Tectonophysics $342,61-80$.

Bhagat, S.S., Bass, J.D., Smyth, J.R., 1992. Single-crystal elastic properties of omphacite-C2/c by Brillouin spectroscopy. Journal of Geophysical Research 97, 6843-6848.

Boland, J.N., Tullis, T.E., 1986. Deformation behavior of wet and dry clinopyroxenite in the brittle to ductile transition region. In: Hobbs, B.E., Heard, H.C. (Eds.), Mineral and Rock Deformation: Laboratory Studies. American Geophysical Union Geophysical Monograph 36, pp. $35-49$.

Boundy, T.M., Fountain, D.M., Austrheim, H., 1992. Structural 
development and petrofabrics of eclogite facies shear zones, Bergen Arss, western Norway: implications for deep crustal deformational processes. Journal of Metamorphic Geology 10, 127-146.

Buatier, M., Van Roermund, H.L.M., Drury, M.R., Lardeaux, J.M., 1991. Deformation and recrystallization mechanisms in naturally deformed omphacites from the Sesia-Lanzo zone; geophysical consequences. Tectonophysics 195, 11-27.

Bunge, H.J., 1982. Texture Analysis in Matcrials Sciences. Butterworths, London.

Bystricky, M., Mackwell, S., 2001. Creep of dry clinopyroxene aggregates. Journal of Geophysical Research 106, 13443-13454.

Caby, R., 1994. Precambrian coesite from northern Mali: first record and implications for plate tectonics in the trans-Saharan segment of the PanAfrican belt. European Journal of Mineralogy 6, 235-244.

Canova, G.R., Wenk, H.R., Molinari, A., 1992. Deformation modelling of multi-phase polycrystals: case of a quartz-mica aggregate. Acta Metallurgica et Materialia 40, 1519 1530 .

Castelnau, O., Duval, P., Lebensohn, R.A., Canova, G.R., 1996. Viscoplastic modeling of texture development in polycrystalline ice with a self-consistent approach: comparison with bound estimates. Journal of Geophysical Research 101, 13851-13868.

Chastel, Y.B., Dawson, P.R., Wenk, H.-R., Bennet, K., 1993. Anisotropic convection with implications for the upper mantle. Journal of Geophysical Research 98, 17757-17771.

Eshelby, J.D., 1957. The determination of the elastic field of an ellipsoidal inclusion, and related problems. Proceedings of the Royal Society of London A 241, 376-396.

Fountain, D.M., Salisbury, M.H., 1981. Exposed cross-sections through the continental crust: implication for crustal structure, petrology and evolution. Earth and Planetary Science Letters 56, 263-277.

Godard, G., Van Roermund, H.L.M., 1995. Deformation-induced clinopyroxene from eclogites. Journal of Structural Geology 17, 1425-1443.

Halliday, A.N., Dickin, A.P., Hunter, R.N., Davies, G.R., Dempster, T.J., Hamilton, P.J., Upton, B.G.J., 1993. Formation and composition of the lower continental crust: evidence from Scottish xenolith suites. Journal of Geophysical Research 98, 581-607.

Heinich, C.A., 1986. Eclogite facies regional metamorphism of hydrous mafic rocks in the Central Aipine Adula Nappe. Journal of Petrology 27, 123-154.

Helmstaedt, H., Anderson, O.L., Gavasci, A.T., 1972. Petrofabric studies of eclogite, spinel-websterite, and spinel-lherzolite xenoliths from kimberlite-bearing breccia pipes in southeastern Utah and northeastern Arizona. Journal of Geophysical Research 77, 4350-4365.

Ingrin, J., Doukhan, N., Doukhan, J.C., 1991. High-temperature deformation of diopside single crystals. 2, TEM investigation of the induced defect microstructures. Journal of Geophysical Research 96, 142814297.

Ingrin, J., Doukhan, N., Doukhan, J.C., 1992. Dislocation glide systems in diopside single crystals deformed at $800-900^{\circ} \mathrm{C}$. European Journal of Mineralogy 4, 1291-1302.

Jahn, B., Caby, R., Monie, P., 2001. The oldest UHP eclogites of the world: age of UHP metamorphism, nature of protoliths and tectonic implications. Chemical Geology 178, 143-158.

Ji, S., Salisbury, M., Hunmer, S., 1993. Petrofabric, P-wave anisotropy and scismic reflectivity of high-grade tectonites. Tectonophysics 222, 195226.

Krabbendam, M., Dewey, F., 1998. Exhumation of UHP rocks by transtension in the Western Gneiss Region, Scandinavian Caledonides. In: Holdsworth, R.E., Strachan, R.A., Dewey, J.F. (Eds.), Continental Transpressional and Transtensional Tectonics. Geological Society of London, Special Publication 135, pp. 159-181.

Krieger Lassen, N.C., 1996. The relative precision of crystal orientations meastred from electron backscattering patterns. Journal of Microscop $181,72-81$.

Lavie, M.P., 1998. Déformation expérimentale du diopside polycristallin. $\mathrm{Ph} . \mathrm{D}$. thesis, Paris XI Orsay.
Lebensohn, R.A., Tomé, C.N., 1993. A self-consistent anisotropic approach for the simulation of plastic deformation and texture development of polycrystals: application to zirconion alloys. Acta Metallurgica et Materialia 41, 2611-2624.

Mauler, A., Bystricky, M., Kunze, K., Mackwell, S., 2000. Microstructure and lattice preferred orientations in experimentally deformed clinopyroxene aggregates. Journal of Structural Geology 22, 1633-1648.

Mauler, A., Godard, G., Kunze, K., 2001. Crystallographic fabrics of omphacite, rutile and quartz in Vendec eclogites (Armorican Massif, France). Consequences for deformation mechanisms and regimes. Tectonophysics 342, 81-112.

Mockel, J.R., 1969. The structural petrology of the garnet peridotite of Alpe Arami (Ticino, Switzerland). Leidse Geologische Mededlingen 42, $61-130$.

Molinari, A., Canova, G.R., Azhy, S., 1987. A self-consistent approach of the large deformation polycrystal viscoplasticity. Acta Metallurgica 35, 2983-2994.

Nicolas, A., Poirier, J.P., 1976. Crystalline Plasticity and Solid State Flow in Metamorphic Rocks. Wiley, New York.

Philippot, P., Van Roermund, H.L.M., 1992. Deformation processes in eclogitic rock: evidence for the rheological delamination of the oceanic crust in deeper levels of subduction zones. Journal of Structural Geology 14, 1059-1077.

Pipenbreier, D., Stöckert, B., 2001. Plastic flow of ompfacite in eclogites at temoperatures below $500^{\circ} \mathrm{C}$-implications for interplate coupling in subduction zones. International Journal of Earth Sciences 90, 197 210.

Pin, C., Sills, J.D., 1986. Petrogenesis of layered gabbros and ultramafic rocks from Val Sesia, NW Italy: trace elements and isotope geochemistry. In: Dawson, J.B., Carswell, D.A., Hall, J., Wedepohl, K.H. (Eds.), The Nature of the Continental Crust. Geological Society Special Publication 24, pp. 231-249.

Raterron, P., Jaoul, O., 1991. High-temperature deformation of diopside single crystal. 1, Mechanical data. Jountal of Geophysical Research 96, $14277-14286$.

Raterron, P., Doukhan, N., Jaoul, O., Doukhan, J.C., 1994. High temperature deformation of diopside IV: predominanec of $\{110\}$ glide above $1000^{\circ} \mathrm{C}$. Physics of the Earth and Planetary Interiors 82, 209-222.

Siegesmund, S., Takeshita, T., Kern, H., 1989. Anisotropy of Vp and Vs in an amphibolite of the deeper crust and its relationship to the mineralogical, microstructural and textural characteristics of the rock. Tectonophysics $157,25-38$.

Stöckert, B., Renner, J., 1998. Rheology of crustal rocks at ultra-high pressure. In: Hacker, B.R., Liou, J.G. (Eds.). When Continents Collide: Geodynamics and Geochemistry of Ultrahigh-pressure Rocks. , pp. 5795.

Taylor, G.I., 1938. Plastic strain in metals. Journal of the Institute of Metals $62,301-324$.

Tommasi, A., Maisprice, D., Canova, G., Chastel, Y, 2000. Viscoplastic seff-consistent and equilibrium-based modeling of olivine lattice preferred orientations. Implications for upper mantle seismic anisotropy. Journal of Geophysical Research 105, 7893-7908.

Van Roermund, H.L.M., 1983. Petrofabrics and microstnuctures of omphacites in a high temperature eclogite from the Swedish Caledonides. Bulletin de Minéralogie 106, 709m713.

Van Roermund, H.L.M., Boland, J.N., 1981. The dislocation substructures of naturally deformed omphacites. Tectonophysics $78,403 \sim 418$.

Venables, J.A., Harland, C.J., 1973. Electron back-scattering patterns--a new technique for obtaining crystallographic information in the scanning electron microscope. Ptilosophical Magazine 27, 1193-1200.

Wenk, H.-R., Bennet, K., Canova, G.R., Molinari, A., 1991. Modelling plastic deformation of peridotite with the self-consistent theory. Journal of Geophysical Research 96, 8337-8349.

Zhang, R.Y., Hirajima, T., Banno, S., Cong, B., Ljou, J.G., 1995. Petrology of ultrahigh-pressure rocks from the southern Su-Lu region, eastern China, Journal of Metamorphic Geology 13, 659 675. 


\section{$\underline{A N E X O ~ I I I}$}




\title{
EPSL
}

\section{Titanohematite lattice-preferred orientation and magnetic anisotropy in high-temperature mylonites}

\author{
Jérôme Bascou ${ }^{\mathrm{a}, \mathrm{b}, *}, \mathrm{M}$. Irene B. Raposo ${ }^{\mathrm{b}}$, Alain Vauchez ${ }^{\mathrm{a}}$, \\ Marcos Egydio-Silva ${ }^{b}$ \\ a ISTEEM, Laboratoire de Tectonophysique, Université de Montpellier II and CNRS, Place E. Bataillon cc49, \\ 34095 Montpellier, France \\ b Instituto de Geociências, Universidade de São Paulo, rua do lago, 562, Cep; 05508-900, São Paulo, Brazil
}

Received 20 August 2001; received in revised form 7 January 2002; accepted 10 January 2002

\begin{abstract}
Magnetic and crystallographic fabric studies were performed in mylonitic granulites from a km-wide strike-slip shear zone in the Ribeira Belt (southeastern Brazil). In these mylonites, a strong compositional layering underlines the tectonic foliation and the elongation of titanohematite, amphibole and orthopyroxene crystals defines a mineral stretching lineation. Magnetic fabric deduced from anisotropy of magnetic susceptibility (AMS) measurements and tectonic fabric compare favorably. Rock-magnetic studies show that both paramagnetic and ferromagnetic minerals can be carriers of AMS. The anisotropy of isothermal remanent magnetization, which is due to the shape-preferred orientation of magnetite grains, is coaxial with AMS. Lattice-preferred orientation (LPO) measurements using the electron backscattered diffraction technique show that orthopyroxene, amphibole, biotite and titanohematite have a strong LPO tightly related to the tectonic fabric. Among these four minerals, titanohematite is the only mineral present in relatively large proportions $(>1.5 \%)$ in all studied samples. Titanohematite LPO is characterized by a strong concentration of (0001) poles (c-axes) sub-perpendicular to the foliation and by a distribution of the poles of the $(2 \overline{11} 0)$ and $(10 \overline{1} 0)$ prism planes within the foliation with a maximum close to the lineation. This characteristic LPO is interpreted as resulting from dislocation creep during the mylonitization. Magnetic fabrics and titanohematite LPO fit well: the axis of minimum susceptibility is aligned with the $c$-axis maximum and the axis of maximum susceptibility coincides with the maximum concentration of poles of the prism planes. Titanohematite LPO may provide a valuable constraint for the kinematic interpretation of the magnetic fabrics. 2002 Elsevier Science B.V. All rights reserved.
\end{abstract}

Keywords: lattice; preferred orientation; anisotropy; magnetic susceptibility; electron diffraction analyses; granulites; deformation

\footnotetext{
* Corresponding author. Tel.: +33-467-143602; Fax: $+33-467-143603$.

E-mail addresses: bascou@dstu.univ-montp2.fr (J. Bascou), irene@usp.br (M.I.B. Raposo),vauchez@dstu.univ-montp2.fr (A. Vauchez), megydios@usp.br (M. Egydio-Silva).
}

\section{Introduction}

Measurement of anisotropy of magnetic susceptibility (AMS) is a non-destructive and relatively fast technique that allows the retrieval of the magnetic fabric of rocks. It is widely accepted that the AMS fabric usually correlates well with the flow fabric developed during magmatic or solid-state 
deformation (e.g., [1-3]). Magnetic fabric measurement is then regarded as a reliable method to constrain the kinematics of flow in rocks in which the tectonic structures are difficult to see. However, the AMS fabric may be complex as it results from the combination of all rock-forming mineral contributions. Progress has recently been made in the understanding of the source of magnetic anisotropy through the determination of the anisotropy of remanent magnetization (ARM) fabric in rocks (e.g., $[4,5])$. ARM is based on the measurement of artificial remanent magnetization $[6,7]$ and makes it possible to isolate the contribution of ferromagnetic minerals to the total magnetic anisotropy.

Strain-induced lattice-preferred orientation (LPO) of minerals in deformed rocks is commonly used to constrain the mechanical behavior of minerals and to study the kinematics of deformation (e.g., $[8,9])$. The relationships between crystallographic and magnetic preferred orientations have been investigated by various authors (e.g., [10 13]). However, these investigations have been focused on silicate phases. Few studies deal with iron oxides, although they are often the dominant source of susceptibility. LPOs of hematite ores from the Quadrilátero Ferrífero (Brazil) have been measured by Hrouda et al. [14] using optical and X-ray goniometry techniques, and by Brokmeier [15] and Will et al. [16] using neutron diffraction technique. AMS measurements have been recently performed by Siemes et al. [17] on samples from the same area. These studies together show that both the concentration of $c$-axes of hematite and the minimum axis of magnetic susceptibility are close to the pole of the tectonic foliation. However, in the case of polyphase specimens, $\mathrm{X}$-ray and neutron diffraction techniques are limited and extremely time-consuming (see [18] for discussion). Recent developments of the electron backscattered diffraction (EBSD) technique in the domain of earth sciences (e.g., [19]) allow the measurement of mineral LPOs in polyphase samples with grain size $\geq 1 \mu \mathrm{m}$, even for opaque and low-symmetry minerals.

Kinematic studies in high-grade metamorphic terranes are of primary importance because they may allow tectonic processes active in the middle and lower crust to be recognized. However, due to pervasive recrystallization and annealing in these rocks, lineations and foliations are often difficult to observe and measure. Magnetic anisotropy studies in granulitic terranes may circumvent this difficulty. Thus, the relationships between magnetic fabrics and LPO of rock-forming minerals must be understood in order to constrain the tectonic signature of magnetic fabrics of high-temperature rocks.

To better constrain these relationships we have:(1) determined the anisotropies of magnetic susceptibility and of remanent magnetization for samples from five sites within a granulitic shear zone; (2) measured the LPOs of the major silicate and iron oxide phases in these mylonites; (3) compared the magnetic fabric, LPOs, and finite-strain axes of these tectonites.

\section{Geological setting and petrology of samples}

The Ribeira belt [20] stretches over more than $1000 \mathrm{~km}$ along the southeastern coast of Brazil (Fig. 1). This belt is regarded as resulting from the convergence between the São Francisco and Congo cratons at the end of the Gondwana assembly [21]. In the central part of the Ribeira belt, the deformation results from a continuous tectonic evolution during which two main regimes have successively prevailed (e.g., [22]): early thrusting and nappe emplacement toward the São Francisco craton, i.e., toward the continent, followed by development of dextral transcurrent faults under slightly retrogressive conditions (from $807-877^{\circ} \mathrm{C}$ at $0.6-0.7 \mathrm{GPa}$, to $734-743^{\circ} \mathrm{C}$ at $0.5 \mathrm{GPa}$ [23]). This orogenic event remobilized 2.2 Gyr old gneissic terranes [24]. The peak of metamorphism was dated at $575 \pm 20 \mathrm{Ma}[25,26]$. Synkinematic $P-T$ conditions decrease progressively southwestward, from granulitic to upper greenschist facies in the southernmost part of the Ribeira belt. Metamorphic and tectonic evidence agrees with a transpressional deformation. Finite-element modeling [22] suggests that the initiation of the shear zones and the NE-SW variation in erosion level may have been induced by the indentation of the SE termination of the São Francisco craton. 


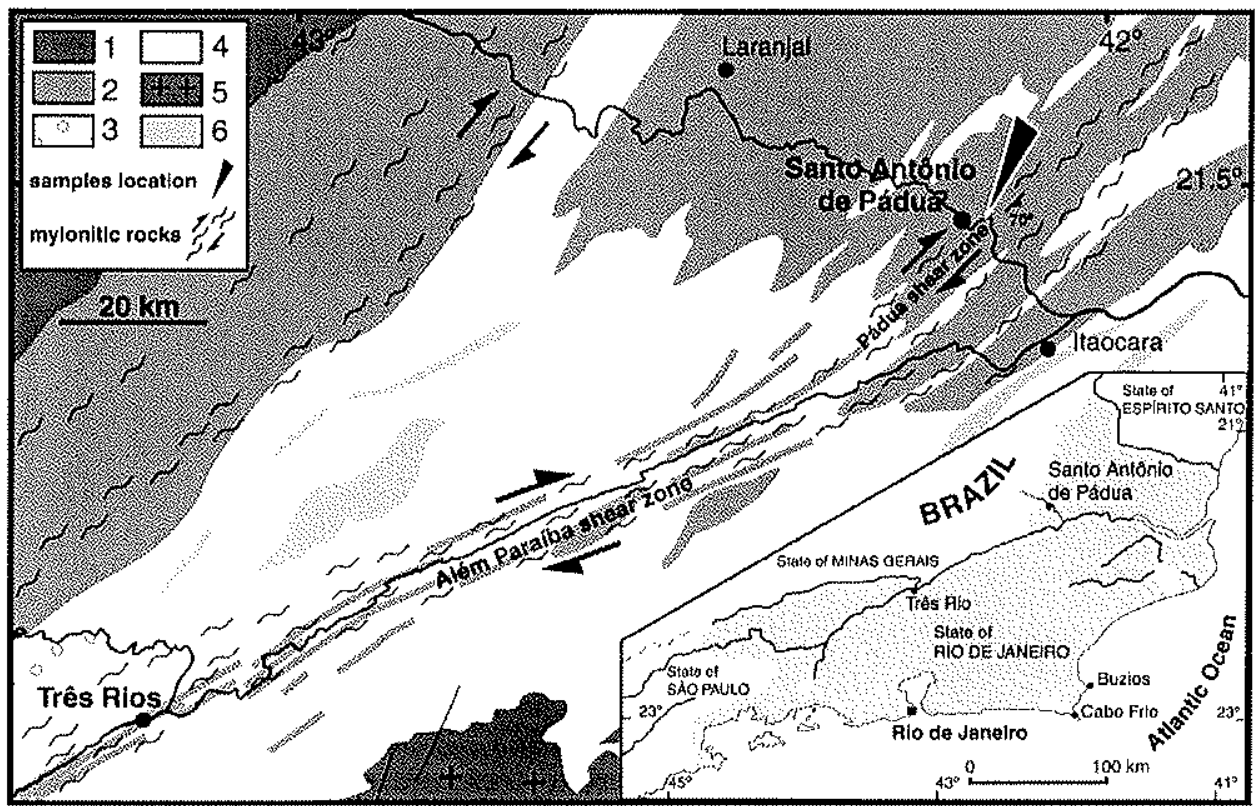

Fig. 1. Schematic geologic map of the Além Paraiba-Pádua shear zone showing the location of the studied samples. (1) Polycyclic basement; (2) granulites and charnockites (Juiz de Fora complex); (3) enderbites; (4) gneisses and migmatites (Paraiba do sul complex); (5) syntectonic granites; (6) marbles (Italva group).

The samples used in this study have been collected in the Pádua shear zone (Fig. 1), which belongs to a larger transcurrent shear zone system (the Além Paraiba-Pádua Shear System) developed in the central domain of the Ribeira belt [27]. In the Pádua shear zone, mylonitic zones several kilometers wide display a pervasive foliation (N040E-70SE) characterized by a compositional layering and a sub-horizontal mineral stretching lineation marked by elongated crystals or mineral aggregates (orthopyroxene, amphibole, feldspar, titanohematite) and boudinage. Asymmetric boudins and mantled feldspar porphyroclasts indicate a dextral sense of shear. Five representative sites characterized by a penetrative deformation at the macroscopic scale have been selected. Four mylonite samples (RB609A, RB538, RB607A, and RB540) display a clear lineation and one (RB614), collected $6 \mathrm{~km}$ away from others, comes from a mylonitic zone where no clear lineation was observed macroscopically. The mineralogy of the studied samples consists mainly of quartz, plagioclase $\left(\mathrm{An}_{20}\right.$ to $\left.\mathrm{An}_{40}\right)$, $\mathrm{K}$-feldspar, biotite, and orthopyroxene and/or amphibole in variable proportions. The microstructure is characterized by alternating, almost monomineralic layers of rectangular quartz crystals or equidimensional recrystallized feldspar grains. The fine-grained (down to $120 \mu \mathrm{m}$ ) feldspar-rich layers contain deformed plagioclase and K-feldspar porphyroclasts (up to $300 \mu \mathrm{m}$ ).

All samples include opaque minerals in proportion ranging from $2 \%$ (RB614) to $9.5 \%$ (RB609A). Reflected-light observations and quantitative analyses using scanning electron microscope (SEM) connected to an X-ray energy dispersive spectrometer (EDS) indicate that the opaque minerals mostly belong to the hematite-ilmenite solid solution. The complete hematite-ilmenite solid solution is conventionally known as titanohematite $\left(x \mathrm{FeTiO}_{3}-(1-x) \alpha \mathrm{Fe}_{2} \mathrm{O}_{3}\right)$ in the rock magnetism literature. The studied samples contain mainly Ti-rich titanohematite close to the ilmenite endmember. The grains either are relatively homogeneous, with thin exsolution lamellae, or display wide lens-shaped exsolutions of Ti-poor titanohematite (ilmeno-hematite or hemoilmenite). Titanohematite grains are strongly elongated parallel 

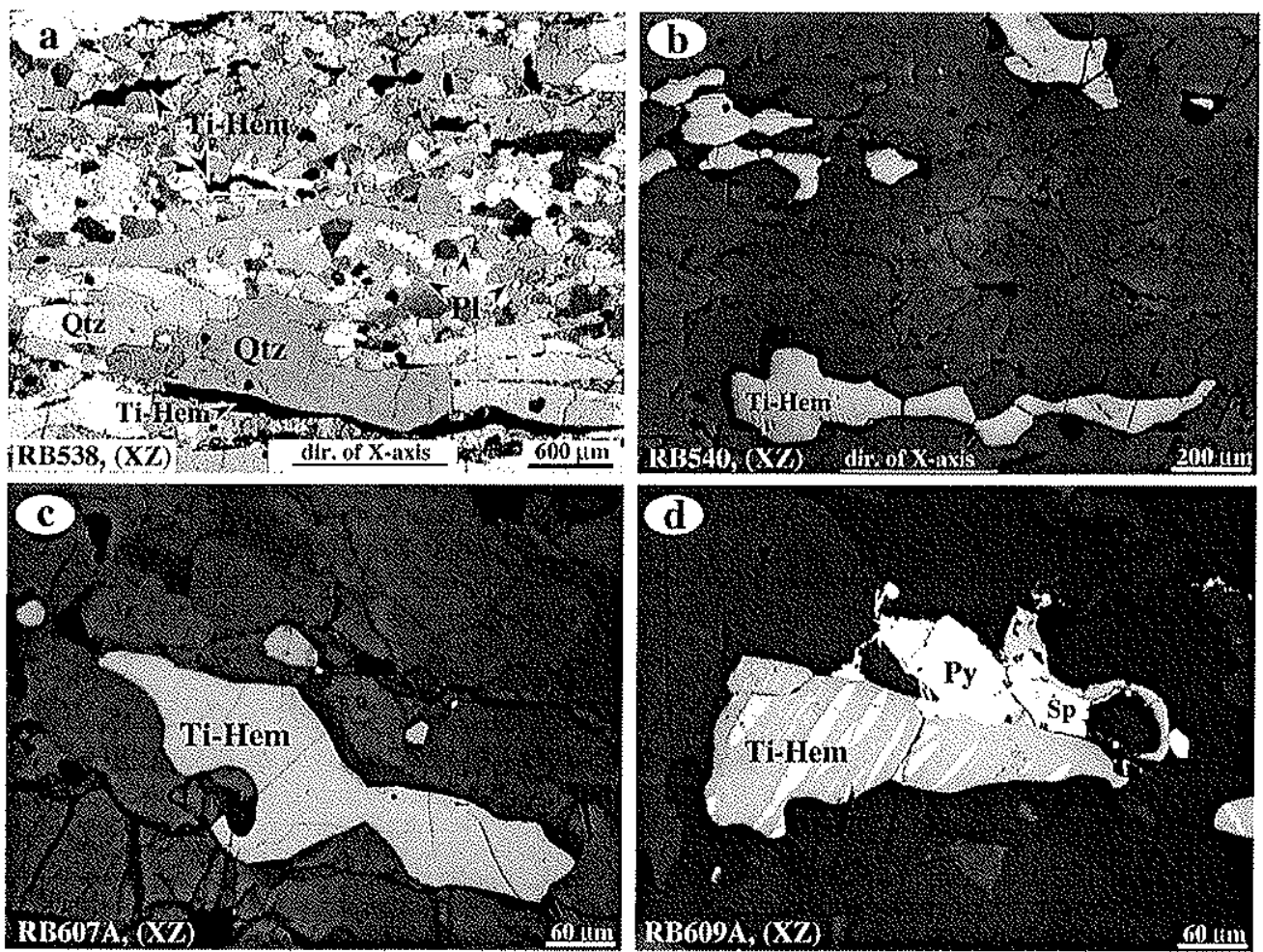

Fig. 2. Photomicrographs showing typical elongated titanohematite grains (Ti-Hem). (a) Typical microstructure of mylonites with polycrystalline quartz ribbons, recrystalized feldspar and elongated titanohematite grains; partially crossed nicols. (b) Titanohematite grains showing thin exsolution lamellae. (c) Ti-rich titanohematite grain without lamellae. (d) Titanohematite showing wide exsolution lenses of Ti-poor titanohematite. Sulfides are represented by pyrite (Py) and sphalerite (Sp). Thin sections parallel to the $x z$ structural plane; $\mathrm{b}-d$ in reflected light.

to the lineation (Fig. 2); their width is on average $50-100 \mu \mathrm{m}$ and their length is variable (up to $1 \mathrm{~mm}$ ). Sample RB538 presents the more elongated titanohematite grains with shape ratio $>7$. Some samples also contain micrometric inclusions and/or thin exsolutions of magnetite. Sulfides, especially pyrite (the most abundant), chalcopyrite, sphalerite and a minor amount of pyrrhotite are also present. They generally replace the $\mathrm{Ti}-\mathrm{Fe}$ oxides and do not display any shape-preferred orientation.

\section{Magnetic measurements}

\subsection{Magnetic mineralogy and rock magnetism}

To determine the magnetic minerals responsible for the magnetic anisotropy in the studied sites, several rock-magnetic experiments were carried out: (a) thermomagnetic curve determinations, (b) coercivity spectra from both anhysteretic remanence and alternating field (AF) demagnetization, (c) thermal demagnetization, (d) isothermal remanent magnetization (IRM) acquisition, and (e) hysteresis measurements.

Thermomagnetic curves were obtained in bulk rock from at least two specimens from each site. The experiments were performed by measuring the susceptibility changes with temperature under Ar atmosphere conditions using Kappabridge instruments (KLY-CS3 and KLY-CS3L, Agico, Czech Republic). In addition, we obtained thermomagnetic curves on concentrated ferromagnetic mineral separates from the specimens from three sites (Fig. 3A). All ferromagnetic mineral 

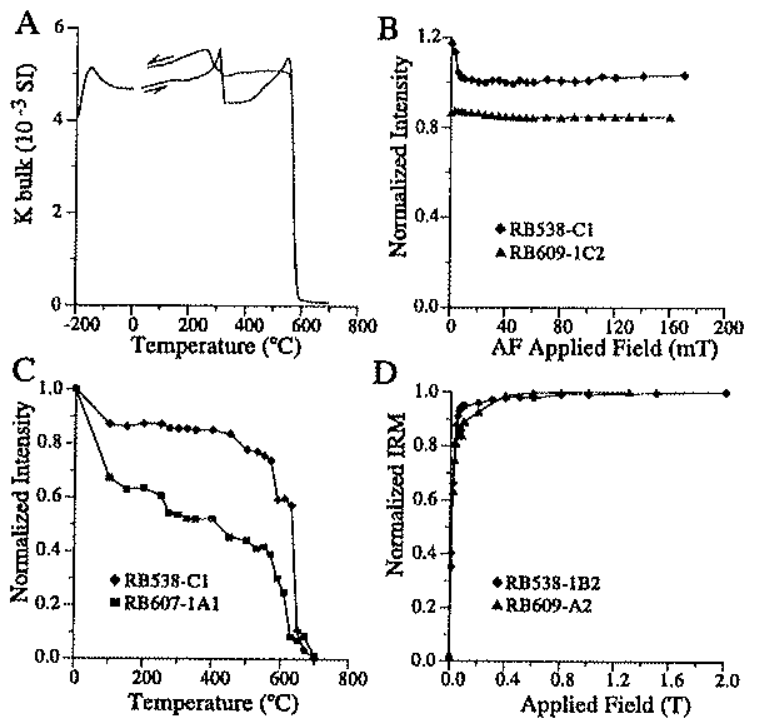

Fig. 3. (A) Representative thermomagnetic curves on ferromagnetic mineral concentrate from specimens RB607. (B) Normalized intensity of magnetization curves versus AF obtained during the AF tumbling demagnetization process. (C) Normalized intensity of magnetization curves versus temperature obtained during the thermal demagnetization process. (D) Examples of isothermal remanent acquisition curves.

concentrations exhibit $\mathrm{K}-\mathrm{T}$ curves with a Hopkinson peak and a sharp decrease in susceptibility. A well-defined pick was observed around $-150^{\circ} \mathrm{C}$ that probably indicates the Verwey transition, characteristic of almost pure magnetite. The high- $T$ susceptibility experiments show a steep decrease in the intensity of susceptibility at temperatures near $580^{\circ} \mathrm{C}$ and around $320^{\circ} \mathrm{C}$ (Fig. $3 \mathrm{~A}$ ), which indicate (titano)magnetite and pyrrhotite, respectively. It is worth noting that pyrrhotite was observed thermomagnetically only in specimens from site RB607 among the analyzed sites.

Coercivity spectra were determined by subjecting samples to stepwise AF demagnetization in a Molspin tumbling demagnetizer (Molspin, Newcastle-upon-Tyne, UK) by fields up to $100 \mathrm{mT}$. Some samples were demagnetized by fields up to $170 \mathrm{mT}$ using a automated three-axis AF demagnetizer coupled to the cryogenic magnetometer. The samples were also subjected to stepwise thermal demagnetization using a non-inductive Schonstedt thermal demagnetizer. The coercivity spectra determined from both anhysteretic remanence [28], and AF demagnetization (Fig. 3B) show that the analyzed samples have both low $(<30 \mathrm{mT})$ and high coercivity. The thermal demagnetization (Fig. 3C) shows blocking temperatures in ranges of $300-350^{\circ} \mathrm{C}, 450-590^{\circ} \mathrm{C}$ and $600-670^{\circ} \mathrm{C}$. These blocking temperatures are coherent with a mixture of pyrrhotites (sample RB607), (titano)magnetite and titanohematite, and suggest a similar contribution of both (titano)magnetite and titanohematite to remanence and AMS. IRM experiments carried out using a pulse magnetometer (MMPM9, Magnetic Measurements) show that the samples reached their complete saturation around 1-1.2 T (Fig. 3D). Saturation in such high fields indicates the presence of titanohematite, as suggested by coercivity and blocking temperature spectra.

Hysteresis measurements at room temperature were performed on at least three samples per site using a vibrating sample magnetometer (VSMNuvo, Molspin, Newcastle-upon-Tyne, UK) in fields up to $1 \mathrm{~T}$. Some typical hysteresis curves are reported in Fig. 4. The curves are symmetrical in all cases. For the majority of the samples, the shape of the hysteresis curve reveals that ferromagnetic grains carry most of the bulk susceptibility. However, they also show that there is a significant contribution of the paramagnetic minerals to the bulk susceptibility as shown by the high-field part of the hysteresis (RB607, RB609, and RB614). Even though it cannot be excluded that the high-field part of the hysteresis is due to the ferromagnetic titanohematite instead of paramagnetic minerals since samples reach the saturation in fields $>1 \mathrm{~T}$ (Fig. 3D) which is higher than maximum VSM applied field (1 T).

\subsection{Anisotropy of low-field magnetic susceptibility (AMS) and magnetic fabrics}

AMS is the tensor which relates the intensity of the applied field $(H)$ to the acquired magnetization $(M)$ of a material through the equation: $M_{\mathrm{i}}=K_{\mathrm{ij}} H_{\mathrm{j}}$, where $K_{\mathrm{ij}}$ is a symmetrical secondrank tensor referred to as the susceptibility tensor [1]. The susceptibility tensor is expressed by its principal eigenvalues (susceptibility magnitudes) and eigenvectors (their orientations), $K_{\text {max }} \geq K_{\text {int }} \geq K_{\operatorname{tmin}}$ representing the maximum, in- 


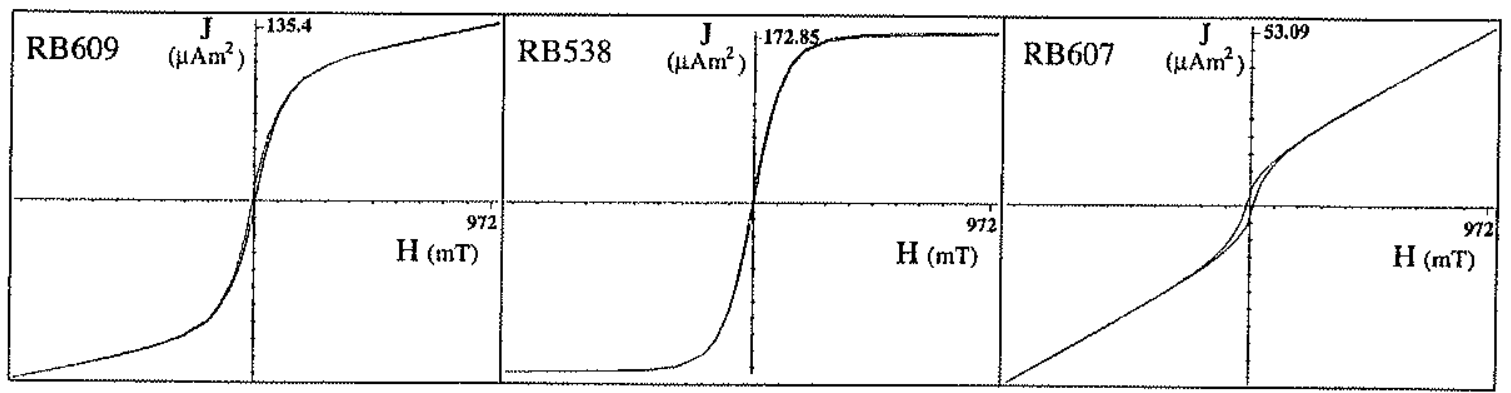

Fig. 4. Hysteresis loops for the specimens from analyzed sites. $J=$ magnetization and $\mathrm{H}=$ applied field.

termediate, and minimum axes of susceptibility, respectively. AMS describes the variation of magnetic susceptibility with direction within a material, and represents the contributions of all rockforming minerals (i.e., dia-, para- and ferromagnetic). The $K_{\max }$ axis represents the magnetic lineation while $K_{\min }$ is the pole of the magnetic foliation (the plane containing $K_{\max }$ and $K_{\text {int }}$ axes).

AMS measurements were performed on $2.5 \times$ $2.2 \mathrm{~cm}$ cylindrical specimens, cut from the oriented cores drilled with a gas-powered portable drill in the sampling sites. At least three specimens from each core were cut. A total of 60 specimens were measured using the KLY-3S Kappabridge (Agico, Czech Republic). AMS data are presented in Table 1. The mean magnetic susceptibility, expressed by $K_{\mathrm{m}}=\left(K_{\max }+K_{\mathrm{int}}+K_{\min }\right) / 3$ in SI units, is generally higher than $10^{-3} \mathrm{SI}$ with an average of $10.68 \times 10^{-3}$. The anisotropy degree, given by $P_{\mathrm{AMS}}=K_{\max } / K_{\min }$, is high $\left(1.510 \leq P_{\mathrm{AMS}} \leq 5.543\right)$. There is no clear relationship between $K_{\mathrm{m}}$ and $P_{\text {AMS }}$ (Table 1). Jelinek's [29] parameter $T_{\text {AMS }}$ $\left(T_{\mathrm{AMS}}=\left(\ln F_{\mathrm{AMS}}-\ln L_{\mathrm{AMS}}\right) /\left(\ln F_{\mathrm{AMS}}+\ln L_{\mathrm{AMS}}\right)\right.$ where $F_{\mathrm{AMS}}=K_{\text {int }} / K_{\min }$ and $\left.L_{\mathrm{AMS}}=K_{\max } / K_{\text {int }}\right)$ shows that the magnetic susceptibility ellipsoids are oblate ( $T_{\text {AMS }}>0$, Table 1 and Fig. 5).

The mean AMS eigenvectors $\left(K_{\max }, K_{\text {int }}\right.$ and $\left.K_{\min }\right)$ and the $95 \%$ confidence cone for each site were calculated using the bootstrap method of Constable and Tauxe [30]. For each site, these eigenvectors are generally well grouped with low values for the $95 \%$ confidence cones. The AMS analysis at the site scale defines the fabrics shown in Fig. 6A. Since both para- and ferromagnetic minerals are present, the AMS is due to a combination of the preferred crystallographic orientations of titanohematite and paramagnetic matrix minerals, and to the shape anisotropy of magnetite grains.

\subsection{ARM and ARM fabrics}

ARM was determined through isothermal remanent magnetization (AIRM; see [6,7] for a review). AIRM measurements were performed using a pulse magnetometer. The procedure involves

Table 1

AMS data

\begin{tabular}{|c|c|c|c|c|c|c|}
\hline \multirow[t]{2}{*}{ Site } & \multirow[t]{2}{*}{ u.c. } & \multirow{2}{*}{$\begin{array}{l}K_{\mathrm{m}} \\
\left(10^{-3} \mathrm{SI}\right)\end{array}$} & \multicolumn{4}{|c|}{ Mean AMS parameters } \\
\hline & & & $L_{\mathrm{AMS}}$ & $F_{\mathrm{AMS}}$ & $P_{\text {AMS }}$ & $T_{\mathrm{AMS}}$ \\
\hline RB538 & 12 & 21.52 & 1.402 & 3.955 & 5.543 & 0.604 \\
\hline RB540 & 11 & 10.70 & 1.174 & 1.325 & 1.557 & 0.270 \\
\hline RB607 & 12 & 3.46 & 1.118 & 1.342 & 1.510 & 0.450 \\
\hline RB609 & 14 & 14.52 & 1.156 & 1.342 & 1.551 & 0.332 \\
\hline RB614 & 11 & 3.18 & 1.058 & 1.711 & 1.810 & 0.811 \\
\hline Means & & 10.68 & 1.182 & 1.935 & 2.394 & 0.493 \\
\hline
\end{tabular}

u.c. $=$ number of specimens measured. The mean susceptibility $K_{\mathrm{m}}$, the lineation $L_{\mathrm{AMS}}$, the foliation $F_{\mathrm{AMS}}$ and Jelinek's parameter $T_{\text {AMs }}$ are defined in the text. 


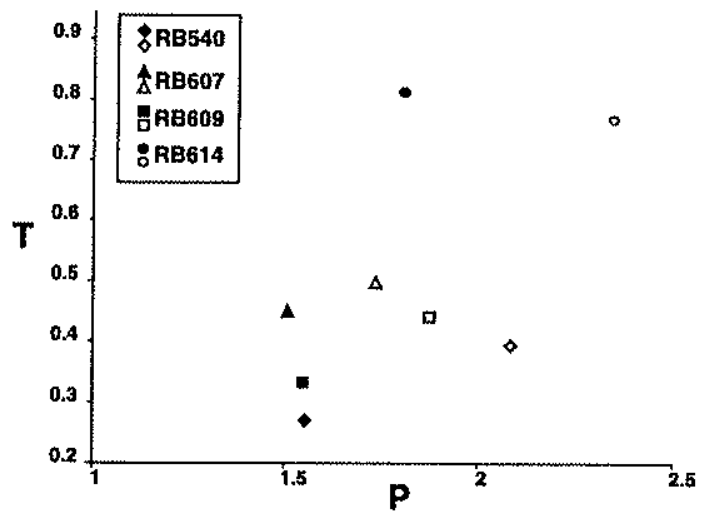

Fig. 5. $P$ versus $T$ (Jelinek's parameter) plot. Black symbols $=$ AMS parameters; white symbols = AIRM parameters. Site RB538 was not included in the figure (see text for explanation).

applying a magnetic field for a short period of time, measurement, and demagnetization along different positions for each specimen. For each position, the IRM is determined as the difference between a remanence magnetization base level and the remanence measured after IRM acquisition. After the measurement and before IRM acquisition in other positions, the specimen must be demagnetized to eliminate the previously imposed magnetization. Six different measurement positions were used since this scheme has proved to be sufficient to calculate the IRM tensors in this study. Before AIRM analysis, samples were demagnetized by AF tumbling at $100 \mathrm{mT}$ to establish the base level. For AIRM determinations the IRM was acquired applying a magnetic field of 20 $\mathrm{mT}$, which was further removed by an AF tumbling demagnetization field of $30 \mathrm{mT}$ (see [28] for discussion). This procedure was repeated for the other positions and the AIRM tensor was calcu-

Fig. 6. Magnetic fabrics determined (A) from anisotropy of low-field magnetic susceptibility (AMS) and (B) from anisotropy of isothermal remanent magnetization (AIRM). Squares = maximum susceptibility and remanence $\left(K_{\max }\right.$, AIR$M_{\text {max }}$ ), triangles = intermediate susceptibility and remanence $\left(K_{\mathrm{int}}, \mathrm{AIRM} \mathrm{M}_{\mathrm{int}}\right)$ and circles = minimum susceptibility and rem. anence $\left(K_{\min }\right.$, AIRM $\left.M_{\min }\right)$. Dashed line ellipses $=95 \%$ confidence ellipses. Equal area, lower hemisphere projections, in the geographical horizontal plane.

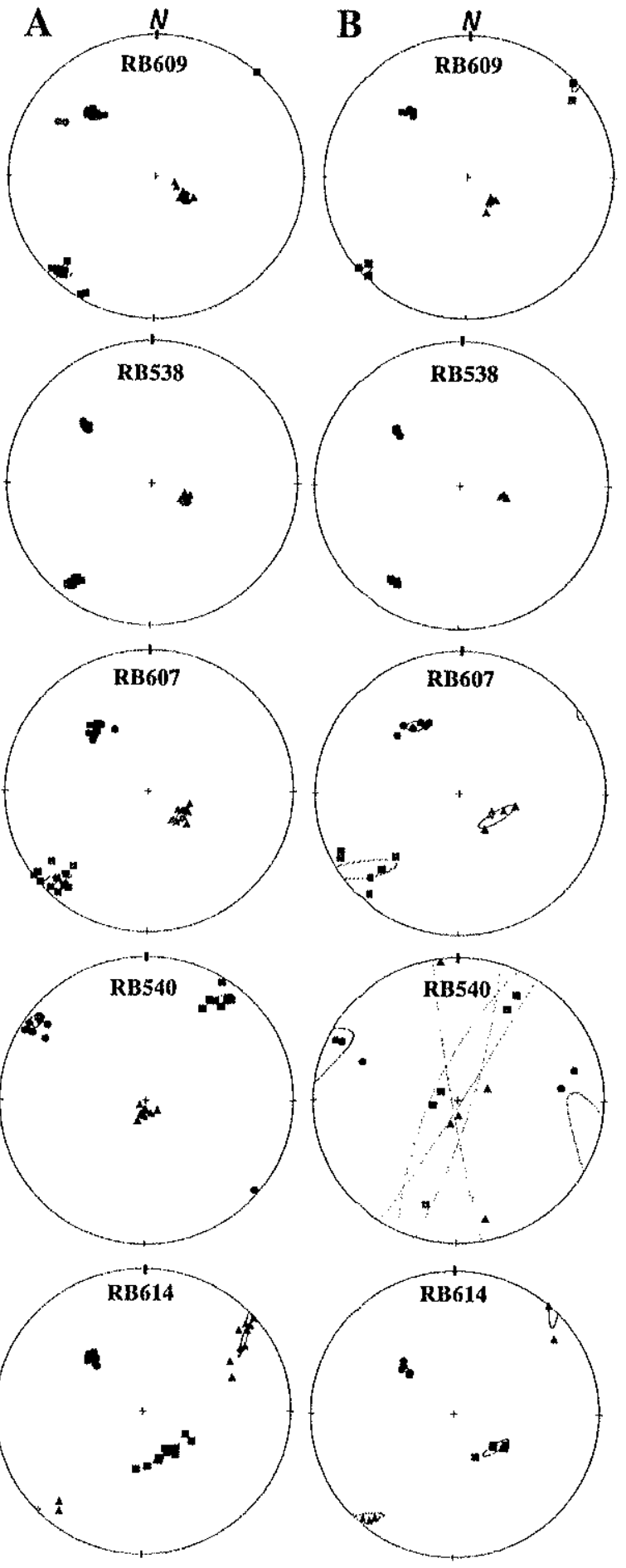


lated by the least-squares method, which showed root-mean-squares $<5 \%$.

As usually observed [6], the anisotropy degree $\left(P_{\text {AIRM }}=\mathrm{AIRM}_{\max } / \mathrm{AIRM}_{\min }\right)$ is more pronounced than $P$ determined from AMS (Fig. 5). RB538 has the strongest magnetic anisotropy. This site is characterized by a very strong $P_{\text {AMS }}$ value $\left(P_{\mathrm{AMS}}=5.543\right)$ and an extreme $P$ value $\left(P_{\text {AIRM }}=17.841\right)$. The ellipsoid shapes are oblate $\left(0.393 \leq T_{\text {AIRM }} \leq 0.767\right)$ in agreement with AMS results (Fig. 5).

The eigenvectors $\left(\right.$ AIRM $_{\max }>\mathrm{AIRM}_{\text {int }}>$ $\mathrm{AIRM}_{\min }$ ) are usually well grouped except for RB540 in which only one eigenvector $\left(\mathrm{AIRM}_{\min }\right)$ has been defined (Fig. 6B). The statistical evaluation followed the bootstrap method [30] originally developed for AMS studies. AIRM has a distinct advantage over AMS because its fabric is exclusively given by the ferromagnetic minerals. Since titanohematite has a high coercivity $(>100 \mathrm{mT})$, AIRM only measures the contribution of magnetite. Therefore eigenvectors of the AIRM tensors (Fig. 6B) indicate the shape-preferred orientation of the magnetite grains. The measured AIRM fabrics are coaxial with AMS fabrics.

\section{Crystallographic fabric}

\subsection{LPO determination}

LPOs were measured using a scanning electron microscope JEOL JSM 5600 through indexation of EBSD [31,32]. Kikuchi bands, which compose the diffraction patterns, are generated by the interaction of a vertical incident electron beam with a planar crystal surface. We used $10 \mathrm{~cm}^{2}$ ultrapolished thin sections, tilted at $70^{\circ}$ from horizontal. A phosphor screen collects the backscattered electrons and gives a photonic image of the EBSD pattern. A low-light, high-resolution digital camera records this photonic image that is then processed and indexed using the CHANNEL+ software (HKL technology). At each point of measurement, the Euler angles $(\varphi 1, \phi, \varphi 2)$ characterizing the orientation of the crystal lattice are determined with a precision better than $1^{\circ}[33]$.

Automatic orientation mapping was not possi-

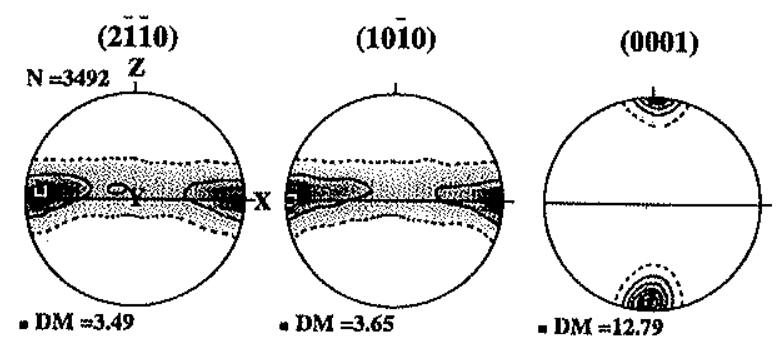

Fig. 7. Hemalite LPO of typical iron ores from the Quadrilátero Ferrifero. Automatic EBSD measurement with a 200 $\mu \mathrm{m}$ step. Analyzed thin section cut parallel to the $x z$ structural plane. Crystallographic orientations projected on equalarea, lower hemisphere in the $x, y, z$ structural frame. Foliation ( $x y$ plane, full line) is vertical $\mathrm{E}-\mathrm{W}$ and the lineation $(x)$ is horizontal in the foliation plane. Contours by $1 \%$ area for $(2 \overline{11} 0)$ and $(10 \overline{1} 0)$ poles, and at $2,4,6 \%$ etc. by $1 \%$ area for (0001) poles. $\mathrm{N}=$ number of measurements and $\mathrm{DM}=$ maximum density.

ble due to the large contrast in mean atomic number between silicate and oxide phases, and to the large variety of mineralogical phases that compose these rocks. Thus lattice orientation of silicate and oxide phases was measured grain-pergrain on the whole surface of the thin sections. We first tested the influence of compositional variations in the hematite-ilmenite series on the indexation of diffraction patterns. The indexation of titanohematite using a set of the 75 strongest reflection bands calculated using either the "hematite structure' (space group $=R \overline{3} c$ ) or the ordered 'ilmenite structure' (space group $=R \overline{3}$ ) yields similar results.

In order to validate this approach, we have measured the LPO of an intensely deformed hematite ore from the Quadrilatero Ferrifero in Minas Gerais (Brazil) that is characterized by a typical lepidoblastic microtexture [34]. For this specific sample, the hematite LPO has been measured using the EBSD automatic measurement procedure. The LPO (Fig. 7) is characterized by the $c$-axes strongly concentrated close to the normal to the foliation, and by the poles of prism planes $(2 \pi 10)$ and $(1010)$ concentrated close to the lineation. This LPO presents a good agreement with those obtained on hematite ores of the Quadrilátero Ferrifero using texture goniometry and, for the $c$-axis, using reflected-light microscopy [14-16]. 


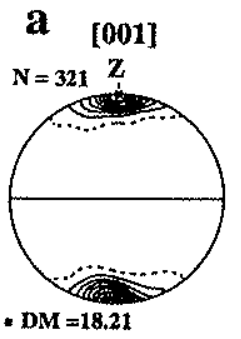

\section{b}
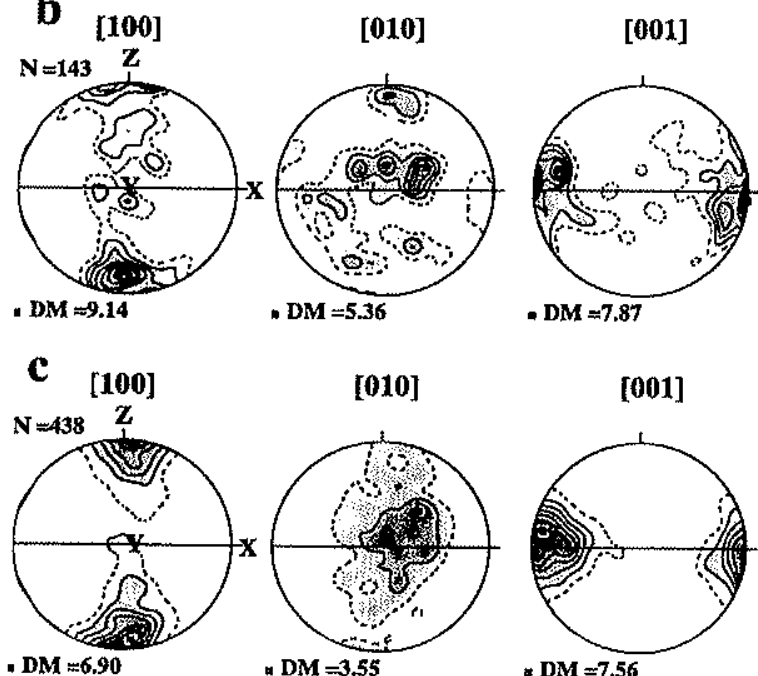

Fig. 8. Typical LPO in mylonites from the Além Paraiba-Pádua shear system. (a) Biotite, sample RB614. (b) Orthopyroxene, sample RB607A. (c) Amphibole, sample 609A. EBSD measurements. Contours at $1,3,5 \%$ for a and at 1,2,3\% for $\mathrm{b}$ and $\mathrm{c}$ by $1 \%$ area. Projection and labels as in Fig. 7 .

\subsection{Results}

Microstructures and LPOs of the main silicates in mylonites outcropping in the Além ParaibaPádua shear system are described in detail in [27] and are interpreted as resulting from hightemperature deformation and extensive annealing. Except for the quartz LPO that shows a complex distribution likely due to post-kinematic annealing, the LPO of silicates is tightly correlated with the tectonic fabric ( $x-, y$-and $z$-axes). The LPO of plagioclase is characterized by [100] axes parallel to the $y$-axis and $(010)$ poles normal to the foliation, and some samples display a submaximum (010) close to the lineation X [35]. The LPO of biotite (Fig. 8a) is characterized by the $c$-axes parallel to the $z$-axis. The LPO of orthopyroxene and amphibole (Fig. 8b,c) shows (100) poles concentrated close to $z,[010]$ axes close to $y$, and [001] axes close to $x$.

Among the $\mathrm{Fe}$ - Ti oxides, deformed titanohematite is largely dominant. Magnetite is difficult to observe in reflected light since it appears in micro-domains (a few $\mu \mathrm{m}$ in size), included in elongated titanohematite grains. The number of diffraction patterns indexed as magnetite (spinel structure) in micro-domains varies from sample to sample but is generally lower than 90 among a total larger than 900 crystals (silicates and iron oxides) indexed. LPO of magnetite determined from these diffraction patterns is very weak; magnetite is almost randomly oriented. Fig. 9 shows the strongest magnetite LPO measured. The [100] axis is characterized by numerous concentrations distributed on the whole hemisphere, and the maximum density $(\mathrm{DM}=3.04)$ is located at ca. $40^{\circ}$ of the lineation. The [111] and [110] axes are almost randomly oriented. In contrast, titanohematite displays a strong LPO characterized by $(0001)$ poles ( $c$-axes) concentrated normal to the foliation. The poles of the prism planes (2i10) and $(10 \overline{10})$ tend to form a girdle parallel to the foliation, which contains a maximum close to the lineation (Fig. 10a,b). Fig. 10c shows a representative inverse pole figure calculated for sample RB607A. The pole of the foliation (z) is strongly concentrated parallel to the cmaxis and the lineation is scattered in the basal plane with weak maximum close to the poles of the prism planes. This LPO of titanohematite is typical of basal slip in trigonal minerals (such as quartz for instance). Similar LPO patterns have been described for ilmenite in a gabbroic shear zone by Agar and Lloyd [36] and are interpreted as resulting from

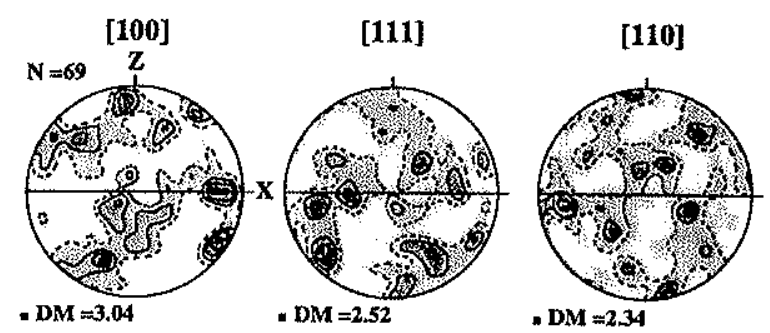

Fig. 9. Magnetite LPO of sample RB538. Contours at 1, 1.5, $2 \%$ by $1 \%$ area. Projection and labels as in Fig. 7. 
86
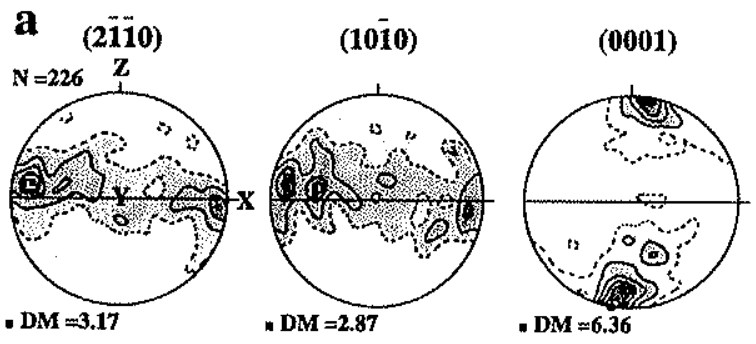

b (2i10)

(1010)
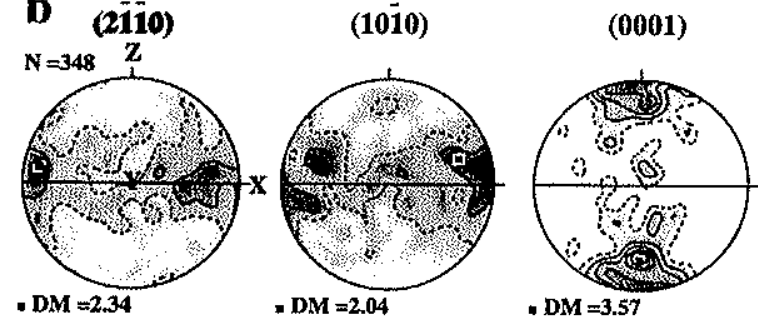

c
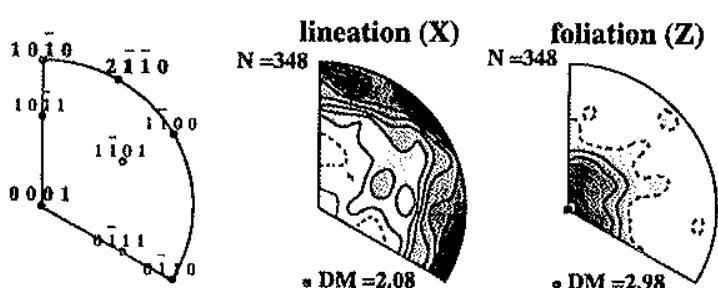

Fig. 10. Titanohematite LPO. (a,b) Pole figures for samples RB609A (a) and RB607A (b). Contours at 1, 1.5, 2, 2.5, 3\% etc. by $1 \%$ area for $(2 \overline{110}),(10 \overline{10})$ poles, and at $1,2,3 \%$ etc. by $1 \%$ area for $(0001)$ poles for a. Contours at $1,1.5,2,2.5$, $3 \%$ etc. by $1 \%$ area for b. Projection and labels as in Fig. 7. (c) Inverse pole figures for sample RB607A showing the projection of lineation $(x)$ and the pole of the foliation $(z)$ in the crystallographic reference frame (upper-hemisphere projection). Contours at $0.2,0.4,0.6 \%$ etc. by $1 \%$ area for the lineation and at $1,1.5,2,2.5,3 \%$ etc. by $1 \%$ area for the foliation. A reference plot showing the poles of crystallographic planes is displayed on the left.

dislocation creep. Dislocation glide on the basal plane, followed by grain boundary migration and anisotropic grain growth, was invoked to explain the development of the strong hematite LPO (e.g., Fig. 7) in naturally deformed hematite from the Quadrilátero Ferrífero [37]. Experimental deformation of fine-grained hematite [38] shows that strain accommodation through dislocation glide on (0001) increases for temperatures above $700^{\circ} \mathrm{C}$. Basal slip was also observed during hightemperature experimental deformation of syn- thetic corundum [39]. At low temperature, microfracturing, twinning on $r\{10 \overline{1} 1\}$ and (0001), and prismatic slip $\{\mathrm{a}\}\langle\mathrm{m}\rangle$ from $200^{\circ} \mathrm{C}$, are the main deformation mechanisms [40,41].

In conclusion, since titanohematite grains are elongated parallel to the macroscopic lineation and its measured LPO displays a simple and consistent correlation with the tectonic fabric, we suggest that titanohematite LPO results from dislocation creep during high-temperature plastic deformation. The good correlation of the titanohematite LPO with the LPO of the main silicate minerals (orthopyroxene, amphibole and plagioclase) strengthens this interpretation.

\section{Comparison between magnetic and crystallographic fabric}

To allow comparison, magnetic, crystallographic and tectonic fabrics for all samples have been plotted in geographic coordinates (Fig. 11). To compare the LPOs with the principal mean susceptibility axes, the eigenvalues and eigenvectors of the normalized orientation tensors [42] were calculated from LPOs. The best axis is given by the eigenvector of the largest eigenvalue, and the pole to the best plane by the smallest one. In addition, the fabric strength is expressed by the dimensionless texture index $J$ [43], which ranges between 1 (random LPO) and infinity (single crystal). In our calculations, the $J$ index has an upper bound of ca. 250 due to truncation at degree 22 of the spherical harmonic series expansion.

As already stated, AMS represents the sum of the para-, dia- and ferromagnetic contributions. Ferromagnetism is mainly carried by iron oxides (mostly Ti-poor titanohematite and magnetite). Magnetite has a very high susceptibility ( $>2 \mathrm{SI}$ ) and a very low magnetocrystalline anisotropy [3]; its AMS is controlled dominantly by the grain shape (e.g., $[44,45])$. In the studied samples, titanohematite shows compositional variations. SEM-EDS analyses show that most grains are Ti-rich titanohematite close to the ilmenite endmember with exsolutions of Ti-poor titanohemalite close to the hematite end-member. The mean susceptibility reported for hematite ranges be- 
tween $2 \times 10^{-3}$ and $8 \times 10^{-2}$ SI [34]. Hematite has a very high intrinsic crystallographic magnetic anisotropy with the direction of maximum susceptibility in the basal plane and the direction of minimum susceptibility along the $c$-axis; its anisotropy degree $(P)$ is frequently greater than 100 [46]. Paramagnetic minerals are mostly represented by Ti-rich titanohematite orthopyroxene, amphibole and biotite; their AMS is due to their magnetocrystalline anisotropy (e.g., [7]). EBSD measurements show that orthopyroxene, amphibole, biotite and titanohematite have a strong LPO tightly correlated with the tectonic fabric. Among these minerals, titanohematite is the only ubiquitous mineral and its volume fraction is relatively large $(>1.5 \%)$. We have therefore focused on the comparison between the LPO of titanohematite and the magnetic fabric.

The minimum susceptibility axis $\left(K_{\min }\right)$ of the ASM fabric, the best $c$-axis of titanohematite (Fig. 11), and the pole of the macroscopic foliation plane ( $p$ in Fig. 11) are close to each other. The maximum concentrations of (2110) and (1010) poles in the well-lineated samples RB609A, RB538, RB607A and RB540, although relatively weak, lie close to the maximum susceptibility axis $\left(K_{\max }\right)$. The best axis (E1, Fig. 11) of (2110) and (10) prism planes and $K_{\max }$ are almost parallel to the lineation ( 1 in Fig. 11). These relationships between $K_{\min }, K_{\text {int }}$ and $K_{\max }$ and the LPO of titanohematite are consistent with relationships given by Uyeda et al. [46] for the hematite and ilmenite-hematite single crystal (i.e., $\left(K_{\max }, K_{\text {int }}\right)$ ithe basal plane, and $\left.K_{\text {min }}[0001]\right)$. For RB614, which displays no clear lineation although the foliation is well-marked, [0001] is strongly concentrated normal to the foliation, and the $(2 \overline{10})$ and $(10 \overline{10})$ poles are scattered in the foliation plane. Fig. 6A shows that the axes of minimum susceptibility defined for RB614 are strongly concentrated parallel to the best $c$-axis and close to the pole of the macroscopic foliation plane (Fig. 11), whereas the axes of both intermediate and maximum susceptibility tend to form a girdle within the foliation plane. For sample RB614, AlRM fabric (Fig. 6B) shows a concentration of the axes of maximum remanence that contrasts with the dispersion of the maxi- mum susceptibility axes (Fig. 6A). AIRM was not measured for all specimens for which AMS was measured (5 and 11 specimens, respectively) and this may impede any detailed comparison. In addition, the axes [001] of amphibole ( $\sim 7 \mathrm{vol} \%)$ tend to be scattered in the foliation plane (Fig. 12) and present a clear maximum of concentration parallel to the density maximum of $(2 \overline{110})$ poles of titanohematite (Fig. 11). The maximum concentration of amphibole [001] axes might represent a faint mineral lineation; it is noteworthy that it is located at ca. $50^{\circ}$ of both $K_{\max }$ (Fig. 12) and the concentration of the axes of maximum remanence which is associated to the shape-preferred orientation of magnetite.

In the lineated mylonites, clustered axes of minimum, intermediate and maximum susceptibility correlate well with the strain-induced LPO of titanohematite. $K_{\min }$ is close to the maximum concentration of $c$-axes and located close to the pole of the macroscopic foliation plane, and $K_{\max }$ is close to the maximum concentration of prism planes pole and sub-parallel to the lineation. In RB614, characterized by a strong macroscopic foliation, the AMS fabric symmetry reflects an axial symmetry around the $c$-axes of titanohematite. Therefore, in all the studied samples, the correlation between AMS fabrics and titanohematite LPO confirms that titanohematite contributes largely to the observed magnetic foliation and/or lineation.

\section{Kinematic analysis and fabric strengths}

In all but RB614 mylonite samples (Fig. 11), the magnetic lineation $\left(K_{\max }\right.$ ) and the maximum concentration of poles to $(2 \overline{110})$ and $(10 \overline{10})$ are slightly oblique with respect to the macroscopic stretching lineation $(x)$. Such an obliquity between the finite strain axes and the LPO is usually regarded as a potential shear sense indicator (e.g., [8]). The obliquity suggests a dextral sense of shear, for example RB609A, RB538 and RB607A, coherent with macroscopic kinematic indicators observed in the Pádua shear zone $[27,35]$. An unexpected sinistral shear sense is suggested for RB540, sampled $5 \mathrm{~km}$ away from the 


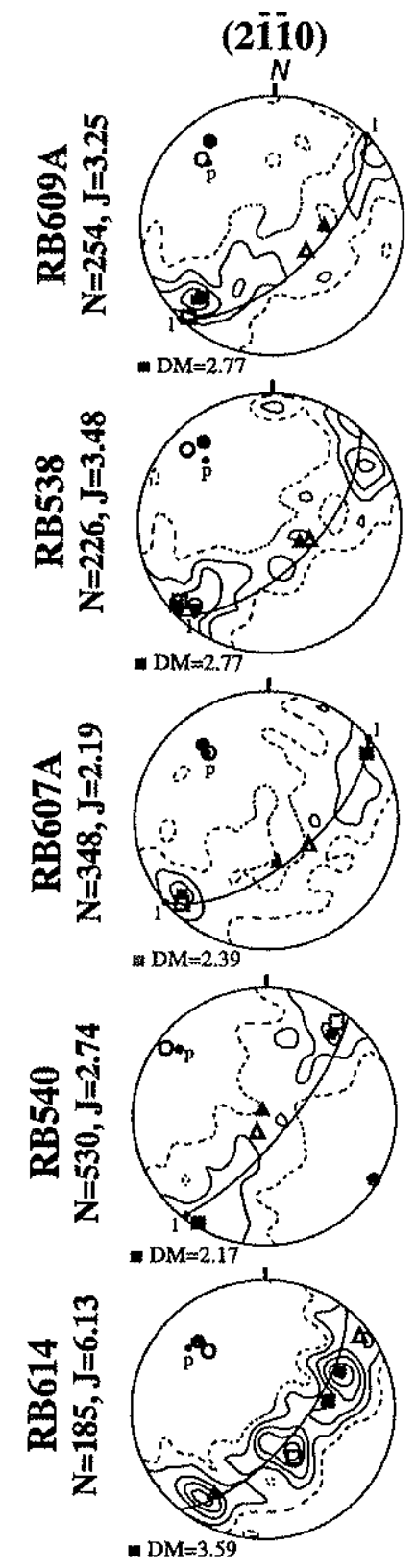

Crystallographic fabric symbols

$$
\begin{aligned}
& \text { E1 - best axis } \\
& \text { AE2 - best pole }
\end{aligned}
$$

\section{(10i0)}
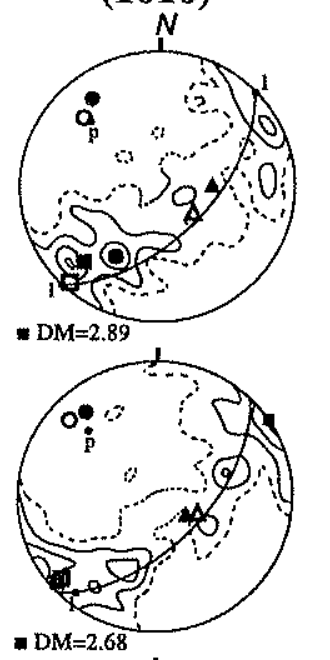

- $\mathrm{DM}=2.68$

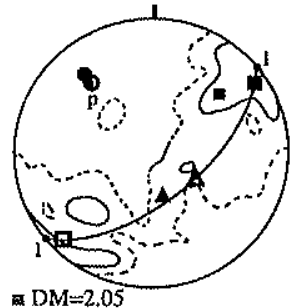

ax $\mathrm{DM}=2.05$

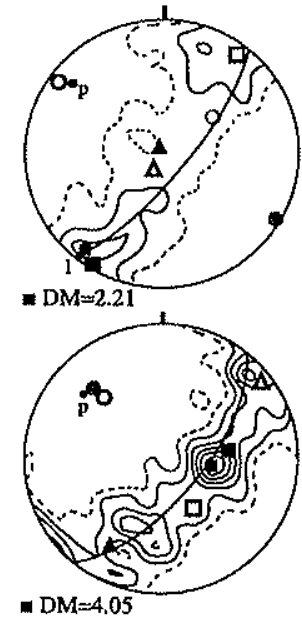

Magnetic fabric symbols

DK1 - maximum susceptibility $\triangle K_{2}$ - intermediate susceptibility

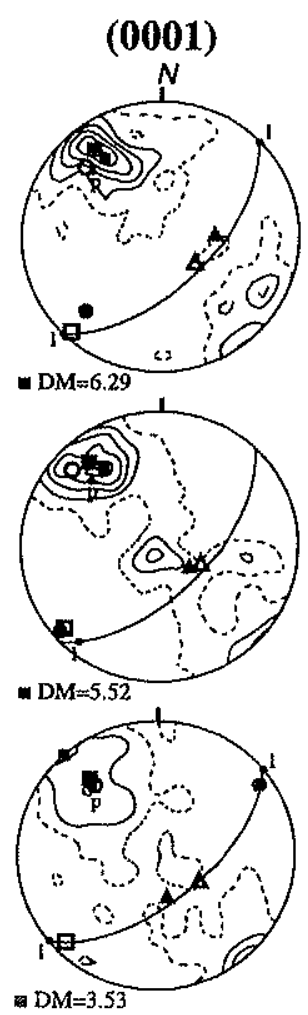

- $D M=3.53$
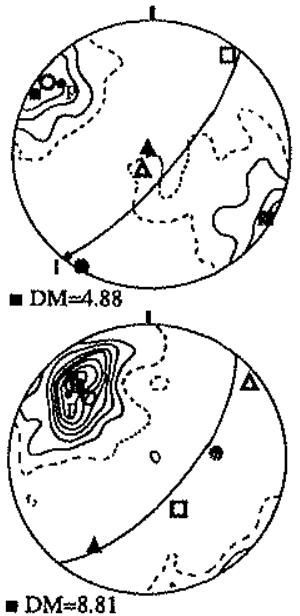

Structural data

foliation

-p foliation pole -1 lineation

Fig. 11. Titanohematite LPOs from all samples plotted in the geographic reference frame. The mean eigenvectors $\left(K_{\max }, K_{\text {int }}\right.$ and $\left.K_{\min }\right)$, and the tectonic foliation and lineation are also plotted. Equal-area projections. Contours at $1,1.5,2,2.5,3 \%$ etc. by $1 \%$ area for $(2 \overline{1} 0),(10 \overline{1} 0)$ poles, and at $1,2,3 \%$ etc. by $1 \%$ area for $(0001)$ poles. $N$, DM as in Fig. $7 ; J=$ fabric strength. 

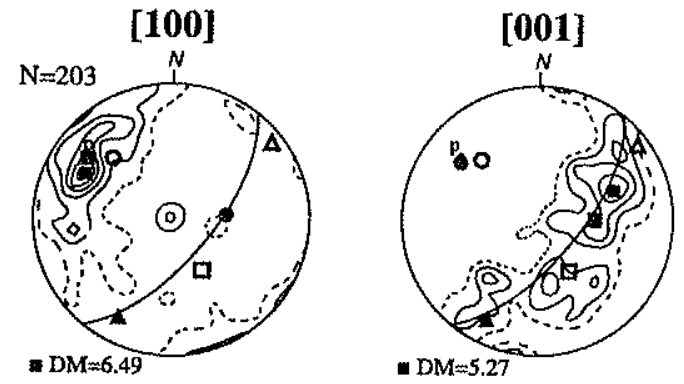

Fig. 12. Amphibole LPO of sample RB614 plotted in the geographic reference frame, equal-area projections. Contours at $1,2,3 \%$ etc. by $1 \%$ area. The mean eigenvectors $\left(K_{\max }\right.$, $K_{\text {int }}$ and $\left.K_{\min }\right)$ are also plotted. $p=$ pole of the tectonic foliation; N, DM as in Fig. 7.

other mylonitic samples. Moreover, the obliquity of the magnetic fabric relative to the structural axes also suggests a sinistral shear. This consistency strengthens the link between the AMS fabric and the LPO of titanohematite.

To compare the magnetic and crystallographic fabric strengths, we have adopted the approach used by Yaouancq and MacLeod [13]. For each crystallographic axis, the eigenvalues $S 1 \geq S 2$ $\geq S 3$ are calculated from the mean orientation matrix normalized by the number of measurements for each sample. The mean crystallographic fabric parameters $L_{L P O}$ (strength of the titanohematite lineation) and $F_{\text {LPO }}$ (strength of the titanohematite foliation) are given by $L_{\mathrm{LPO}}=S 1 / S 2$ for (2T10), and $F_{\mathrm{LPO}}=S 1 / S 2$ for $(0001)$. The strength of the titanohematite fabric ellipsoid axes $R 1, R 2$ and $R 3$ is computed from the $L_{\mathrm{LPO}}$ and $F_{\mathrm{LPO}}$ parameters using $F_{\mathrm{LPO}}=R 2 / R 3, \quad L_{\mathrm{LPO}}=R 1 / R 2$ and $R 1+R 2+R 3=1$. Finally, $R 1, R 2$ and $R 3$ are used to calculate Jelinek's shape factor: $T_{\mathrm{LPO}}=[\ln (R 2 / R 3)-\ln (R 1 / R 2)] /[\ln (R 2 / R 3)+\ln (R 1 /$ $R 2)$ ] and the anisotropy degree $P_{\mathrm{LPO}}=R 1 / R 3$ (Table 2). Sample RB607A has the weakest LPO of [0001] axes characterized by the lowest $J$ index (2.19). Variations in fabric strengths between lineated mylonites (Fig. 11) may reflect variations in strain intensity across the shear zone. Sample RB607A also displays the less anisotropic crystallographic fabric of titanohematite $\left(P_{\mathrm{LPO}}=1.71\right)$ and the lowest magnetic anisotropy $\left(P_{\mathrm{AMS}}=\right.$ 1.51; Table 1). However, the anisotropy parameters $P_{\text {LPO }}$ and $P_{\text {AMS }}$ do not show any systematic correlation. This points to other contributions to AMS than titanohematite LPO alone. For instance, the very high degree of magnetic anisotropy $\left(P_{\text {AMS }}=5.54\right)$ of sample RB538 may be due to the combination of the titanohematite LPO with the shape-preferred orientation of magnetite. This inference is supported by the strong fabric (Fig. 10) of titanohematite, the high mean susceptibility $\left(K_{\mathrm{m}}=21.52 \times 10^{-3} \mathrm{SI}\right)$ and the strong AIRM fabric of this sample $\left(P_{\text {AIRM }}>10\right)$.

Jelinek's parameter $T_{L P O}$ calculated from the titanohematite LPO ranges between 0.24 and 0.94 (Table 2). These positive values correlate with the strong concentration of the [0001] axes. The susceptibility ellipsoid and the crystallographic ellipsoid of all samples present an oblate character $\left(T_{\mathrm{AMS}}\right.$ and $\left.T_{\mathrm{LPO}}>0\right)$, but $T_{\mathrm{AMS}}$ (Table 1 ) and $T_{\text {LPO }}$ (Table 2) values do not show any systematic correlation. However, the strongly oblate character of both the susceptibility ellipsoid $\left(T_{\mathrm{AMS}}=0.81\right)$ and crystallographic ellipsoid of titanohematite $\left(T_{\mathrm{LPO}}=0.94\right)$ in sample RB614 is in

Table 2

Fabric parameters from titanohematite LPOS

\begin{tabular}{llllllll}
\hline Sample & $L_{\text {LPO }}$ & $F_{\text {LPO }}$ & $P_{\text {L,PO }}$ & \multicolumn{2}{l}{$T_{\text {LPO }}$} & \multicolumn{3}{c}{ Ellipsoid axes } \\
\cline { 5 - 8 } & & & & & $R$ I & $R 2$ & $R 3$ \\
\hline RB538 & 1.33 & 1.59 & 2.14 & 0.24 & 0.45 & 0.34 & 0.21 \\
RB540 & 1.17 & 1.96 & 2.15 & 0.62 & 0.43 & 0.37 & 0.20 \\
RB607A & 1.18 & 1.55 & 1.71 & 0.53 & 0.41 & 0.35 & 0.24 \\
RB609A & 1.17 & 1.96 & 2.15 & 0.62 & 0.43 & 0.37 & 0.20 \\
RB614 & 1.05 & 5.00 & 4.60 & 0.94 & 0.46 & 0.44 & 0.10 \\
\hline
\end{tabular}

$L_{\mathrm{LPO}}$ (strength of the titanohematite lineation), $F_{L \text { pO }}$ (strength of the titanohematite foliation), Jelinek's shape parameter $T_{\mathrm{LPO}}$ and the anisotropy degree $P_{\text {LPO }}$ are defined in the text. 
agreement with the sub-planar arrangements of $K_{\max }$ and $K_{\text {int }}$ in Fig. 6 , the well-developed foliation and the lack of visible stretching lineation.

\section{Conclusion}

Mylonitic fabric in the high-temperature Pádua shear zone is marked by a strong compositional layering that underlines the foliation, and by titanohematite, amphibole and/or orthopyroxene elongated parallel to the macroscopic lineation.

Magnetic foliation and lineation determined from AMS measurements tend to parallel the macroscopic foliation and lineation observed in the field and in hand specimens. Magnetic studies reveal that both para- and ferromagnetic minerals contribute to the AMS. Ti-rich titanohematite (ilmenite), orthopyroxene, amphibole and biotite in variable proportions represent the paramagnetic minerals. Ferromagnetic minerals are mainly iron oxides (Ti-poor titanohematite, magnetite with subordinated pyrrhotite in RB607). The AIRM fabric, due to the shape-preferred orientation of magnetite grains, is coaxial with the AMS fabric.

LPO data show that orthopyroxene, amphibole, biotite and titanohematite have a strong LPO tightly correlated with the tectonic fabric. Among these minerals, titanohematite is the only mineral present in relatively large proportions $(>1.5 \%)$ in all studied granulitic mylonites. The LPO of titanohematite is characterized by the preferential orientation of $(000 \mathrm{l})$ poles sub-perpendicular to the foliation and by the poles of the prism planes in the foliation plane, which define a girdle containing a maximum concentration close to the lineation in the lineated mylonites. This characteristic LPO likely results from plastic deformation of titanohematite through slip on (0001) planes.

For the studied mylonites, a good correlation is observed between the AMS ellipsoid axes and the LPOs of titanohematite: the axis of minimum susceptibility $\left(K_{\min }\right)$ is close to the maximum concentration of $c$-axes, and the axis of maximum susceptibility $\left(K_{\mathrm{mix}}\right)$ is close to the maximum con- centration of poles of the prism planes. These clear relationships between the AMS axes and the strain-induced LPO of titanohematite provide a strong constraint on the tectonic significance of the measured magnetic fabric. On the other hand, no clear correlation has been established between the intensity of AMS and the fabric strength calculated from the LPO of titanohematite. This lack of correlation highlights that the magnitude and shape of the finite strain ellipsoid cannot be evaluated from AMS measurements when various minerals contribute to the magnetic susceptibility.

In non-mylonitic granulites, it is frequently impossible to measure the tectonic fabric. AMS measurement allows fast and reliable mapping of the magnetic foliation and lineation. Since under high-temperature conditions, titanohematite develops a clear LPO through dislocation creep, measurement of its LPO provides a strong constraint on the magnetic properties of tectonites and the deformation they have undergone. Titanohematite LPO therefore represents a reliable guide for tectonic interpretation of AMS measurements.

\section{Acknowledgements}

We would like to thank D. Mainprice for providing crystallographic fabric analysis programs and for fruitful discussions. We also thank L. Lagoeiro for providing the hematite ore sample and C. Nevado for the ultra-polished thin sections. J.L. Bouchez, F. Boudier and G.E. Lloyd are gratefully acknowledged for their helpful reviews. The crystal orientation measurements were made using the EBSD/SEM system at Laboratoire de Tectonophysique, Université Montpellier II funded by grants from CNRS/INSU, UMI, NSF Project \#EAR-9526840 'Anatomy of an Archean Craton' and ISTEEM. Composition analyses were made using the SEM-EDS system at Instituto de Geociências, Universidade de São Paulo. The authors thank CAPES (Project: 2871 99), FAPESP (Projects: 95/8399-0 and 95/0283-2) and CNPq/CNRS (Project: 910144/98-2) for financial support. $[A C]$ 


\section{References}

[1] F. Hrouda, Magnetic anisotropy of rocks and its application in geology and geophysics, Geophys. Surv, 5 (1982) $37-82$.

[2] P. Rochette, M. Jackson, C. Aubourg, Rock magnetism and the interpretation of anisotropy of magnetic susceptibility, Rev. Geophys. 30 (1992) 209-226.

[3] G.J. Borradaile, B. Henry, Tectonic applications of magnetic susceptibility and its anisotropy, Earth Sci. Rev. 42 (1997) 49-93.

[4] R.I.F. Trindade, M.I.F. Raposo, M. Ernesto, R. Siqueira, Magnetic susceptibility and partial anhysteretic remanence anisotropies in the magnetite-bearing granite piuton of Tourão, NE Brazil, Tectonophysics 314 (1999) 443468.

[5] M.I.B. Raposo, M.S. D'Agrella-Filho, Magnetic fabrics of dike swarms from SE Bahia State, Brazil: their significance and implications for Mesoproterozoic basic magmatism in the São Francisco Craton, Precambrian Res. 99 (2000) 309-325.

[6] M. Jackson, Anisotropy of magnetic remanence: a brief review of mineralogical sources, physical origins and geological applications, and comparison with susceptibility anisotropy, Pure Appl. Gcophys. 136 (1991) 1-28.

[7] D.H. Tarling, F. Hrouda, The Magnetic Anisotropy of Rocks, Chapman and Hall, London, 1993, 217 pp.

[8] J.L. Bouchez, A. Nicolas, G. Lister, Fabric asymmetry and shear sense in movement zones, Geol. Rund. 72 (1983) $401-419$.

[9] A. Nicolas, 3.L. Bouchez, F. Boudier, Interprétation cinématique des déformations plastiques dans le massif de therzolites de Lanzo, Tectonophysics 14 (1972) 143-171.

[10] P. Blumenfeld, J.L. Bouchez, Shear criteria in granite and migmatite deformed in the magmatic and solid states, J. Struct, Geol. 10 (1988) 361-372.

[11] G.J. Borradaile, Magnetic susceptibility, petrofabric and strain, Tectonophysics 156 (1988) 1-20.

[12] K. Benn, P. Rochette, J.L. Bouchez, K. Hattori, Magnetic susceptibility, magnetic mineralogy and magnetic fabrics in a late Archean granitoid-gneiss belt, Precambrian Res. 63 (1993) $59 \ldots 81$.

[13] G. Yaouancq, C.J. MacLeod, Petrofabric investigation of gabbros from the Oman ophiolite: comparison between AMS and rocks fabric, Mar. Geophys. Res. 21 (2000) 289-305.

[14] F. Hrouda, H. Siemes, N. Herres, C. Hennig-Michaeli, The relationship between the magnetic anisotropy and the c-axis fabric in a massive hematite ore, J. Geophys. 56 (1985) 174-182.

[15] H.G. Brokmeier, Neutron diffraction texture analysis of multi-phase systems, Textures Microstruct. 10 (1989) 325345.

[16] G. Will, P. Schäfer, P. Merz, Texture analysis by neutron diffraction using a linear position sensitive detector, Textures Microstruct. 10 (1989) 375-387.

[17] H. Siemes, H. Schaeben, C.A. Rosière, H. Quade, Crys- tallographic and magnetic preferred orientation of hematite in banded iron ores, J. Struct. Geol. 22 (2000) 1747 . 1759.

[18] D. Mainprice, G. Lloyd, M. Casey, Individual orientation measurements in quartz polycrystals: advantages and limitations for texture and petrophysical property determinations, J. Struct. Geol. 15 (1993) 1169-1187.

[19] G.E. Lloyd, D.J. Prior, EBSD technique and application in geosciences, Göttinger Arb. Geol. Paläontol. Sb4 (1999) 112-113.

[20] Y. Hasui, C.D.R. Carneiro, A.M. Coimbra, The Ribeira folded belt, Rev. Bras. Geoci. 5 (1975) 257-266.

[21] R. Trompette, Geology of Western Gondwana (2000-500 Ma), Balkema, Rotterdam, 1994, 350 pp.

[22] A. Vauchez, A. Tommasi, M. Egydio-Silva, Self-indentation of continental lithosphere, Geology 22 (1994) 967970.

[23] C. Porcher, L. Fernandes, M. Egydio-Silva, A. Vauchez, Dados preliminares do metamorfismo M1 da Faixa Ribeira: Região de Três Rios e Santo Antônio de Pádua (RJ), in: $\vee$ Simpósio Nacional de Estudos Tectônicos, Gramado, Brasil, 1995, pp. 71-73.

[24] F. Söllner, B. Lammerer, K. Weber-Diefenbach, Die Krustenentwicklung in der Kustenregion nordlich von Rio de Janeiro/Brasilien, Münch. Geol. Helfe 4 (1991) $1-101$.

[25] N. Machado, C. Vallares, M. Heilbron, C. Valeriano, U-Pb geochronology of the central Ribeira belt (Brazil) and implications for the evolution of the Brazitian Orogeny, Precambrian Res. 79 (1996) 347-361.

[26] H.K. Brueckner, D. Cunningham, F.F. Alkmin, S. Marshak, Tectonic implications of Precambrian Sm-Nd dates from the southern São Francisco craton and adjacent Araçuai and Ribeira belts, Brazil, Precambrian Res. 99 (2000) 255-269.

[27] M. Egydio-Silva, A. Vauchez, J. Bascou, J. Hippertt, High temperature deformation in the Neoproterozoic transpressional Ribeira belt, southeast Brazil, Tectonophysics (2001) in press.

[28] M.I.B. Raposo, M. Egydio-Silva, Magnetic fabric studies of high-grade metamorphic rocks from the Juiz de Fora Complex, Ribeira belt, SE Brazil, Int. Geol. Rev. 43 (2001) $441-456$.

[29] V. Jelinek, Characterization of the magnetic fabrics of rocks, Tectonophysics 79 (1981) 63-67.

[30] C. Constable, L. Tauxe, The bootstrap for magnetic susceptibility tensor, J. Geophys. Res. 95 (1990) 8383-8395.

[31] G.E. Lloyd, N.H. Schmidt, D. Mainprice, D.J. Prior, Crystallographic textures, Mineral. Mag, 55 (1991) 331345.

[32] D.J. Dingley, D.P. Field, Electron backscatter diffraction and orientation imaging microscopy, Mater. Sci. Technol. 13 (1997) 69-78.

[33] N.C. KriegerLassen, The relative precision of crystal orientations measured from electron backscattering patterns, J. Microsc. 181 (1996) 72-81.

[34] C.A. Rosière, H. Quade, H. Siemes, F. Chemale Jr., Fab- 
ric, texture and anisotropy of magnetic susceptibility in high-grade iron ores from the Quadrilatero Ferrifero, Minas Gerais, Brazil, Mater. Sci. Forum 273-275 (1998) 693-700.

[35] M. Egydio-Silva, D. Mainprice, Determination of stress directions from plagioclase fabrics in high grade deformed rocks (Além Paraiba shear zone, Ribeira fold belt, southeastern Brazil), J. Struct. Geol. 21 (1999) 1751-1771.

[36] S.M. Agar, G.E. Lloyd, Deformation of Fe-Ti oxides in gabbroic shear zones from the Mark area, Proc. ODP Sci. Results 153 (1997) 123‥140.

[37] C.A. Rosière, H. Siemes, H. Quade, H.-G. Brokmeier, M. Jansen, Microstructures, textures and deformation mechanisms in hematite, J. Struct. Geol. 23 (2001) 1429-1440.

[38] H. Siemes, B. Klingenberg, G. Dresen, E. Rybacki, M. Nauman, W. Schäfer, E. Jansen, C.A. Rosière, Experimentally and naturally deformed hematite ores, in: VII Simpósio Nacional de Estudos Tectônicos, Lençois, Brasil, 1999, pp. 59, Sessão 5 .

[39] T. Bretheau, J. Castaing, J. Rabier, P. Veyssière, Mouvement des dislocations et plasticité à haute température des oxydes binaires et ternaires, Adv. Phys. 28 (1979) 829 1014.
[40] C. Hennig-Michaeli, Microscopic structure studies of experimentally and naturally deformed hematite ores, Tectonophysics 39 (1977) 255-271.

[41] H. Siemes, C. Hennig-Michaeli, Ore minerals, in: H.-R. Wenk (Ed.), Preferred Orientation in Deformed Metals and Rocks: An Introduction to Modern Texture Analysis, Academic Press, New York, 1985, pp. 335-358.

[42] N.F. Woodcock, M.A. Naylor, Randomess testing in three dimensional orientation data, J. Struct. Geol. 5 (1983) $539-548$.

[43] H.J. Bunge, Texture Analysis in Materials Sciences, Butterworths, London, 1982, $593 \mathrm{pp}$.

[44] C.J. Archanjo, P. Launeau, J.L. Bouchez, Magnetic fabric vs. magnetite and biotite shape fabrics of the magnetitebearing granite pluton of Gameleiras (Northeast Brazil), Phys. Earth Planet. Inter. 89 (1995) 63-75.

[45] V. Grégoire, J. Darrozes, P. Gaillot, A. Nédélec, P. Launeau, Magnetite grain shape fabric and distribution anisotropy vs rock magnetic fabric: a three-dimensional case study, J. Struct. Geol. 20 (1998) 937-944.

[46] Y. Uyeda, M.D. Fuller, J.C. Belshé, R.W. Girdler, Anisotropy of magnetic susceptibility of rocks and minerals, J. Geophys. Res. 68 (1963) 279-291. 
$\overline{S A D I C N A d V}$ 


\section{APÊNDICE I}

OPR DA GRANADA NOS ECLOGITOS

\section{Eclogitos dos Alpes}

[100]
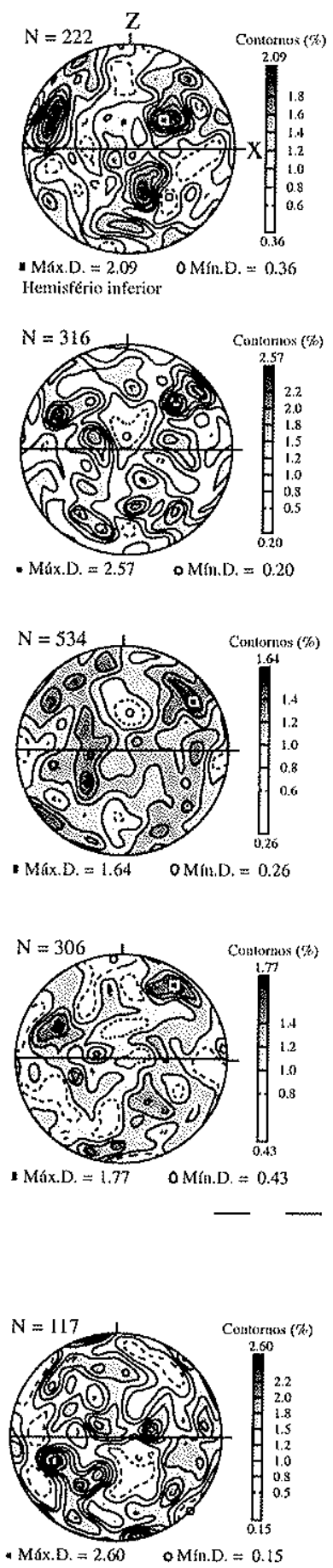

[111]

[110]

AB.E. Alpe Arami
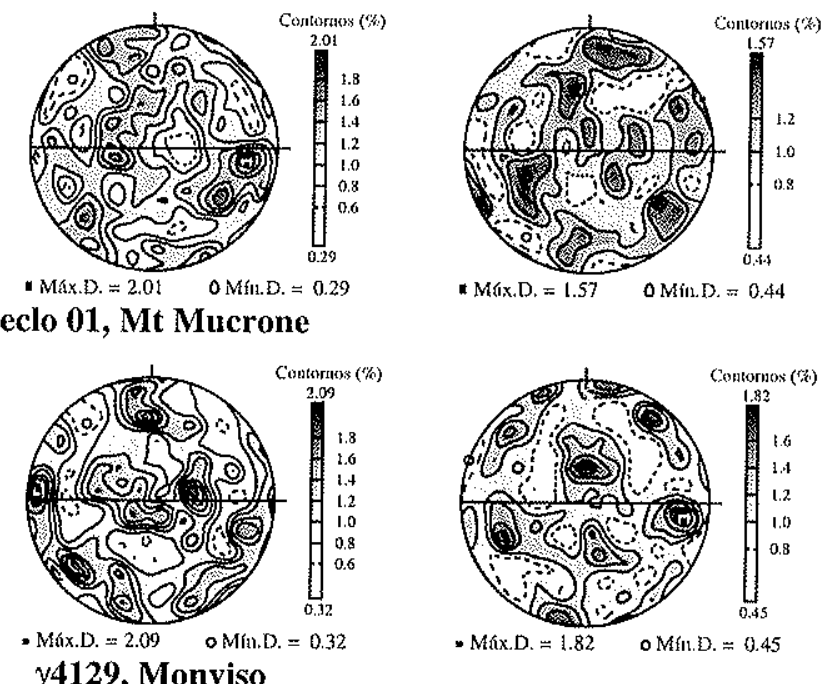

4129, Monviso

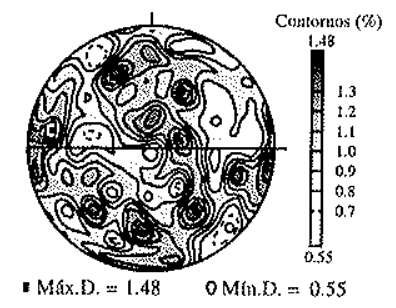
$\gamma 3638$, Siviez-Mischabel
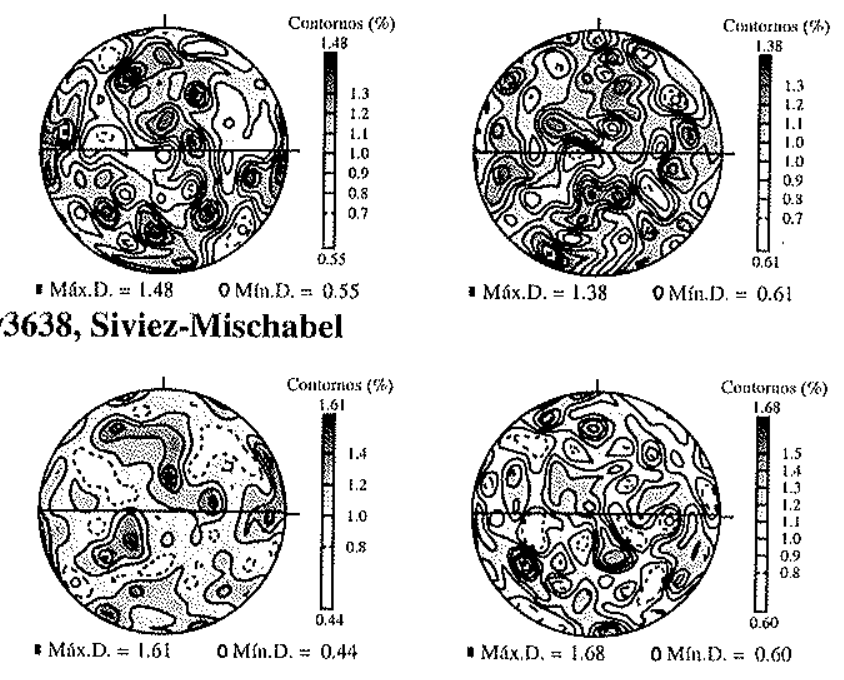

\section{Eclogitos de Sulu} SL50, Sulu

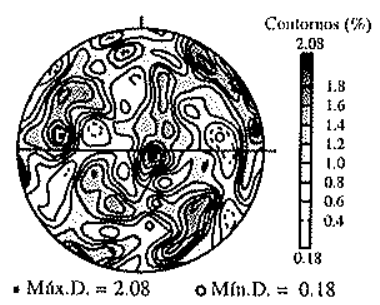

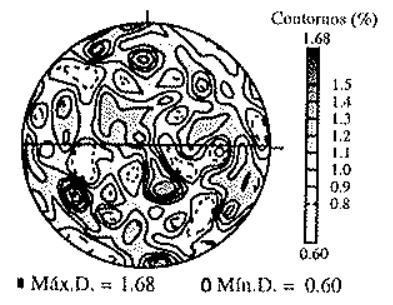

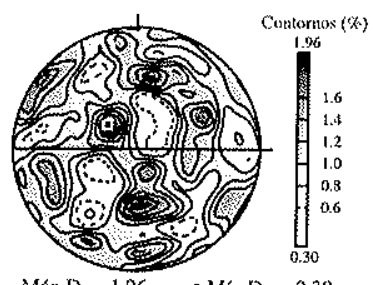




\section{Eclogitos da Noruega}

[100]

[111]

[110]

B6, Nordfjord (WGR)
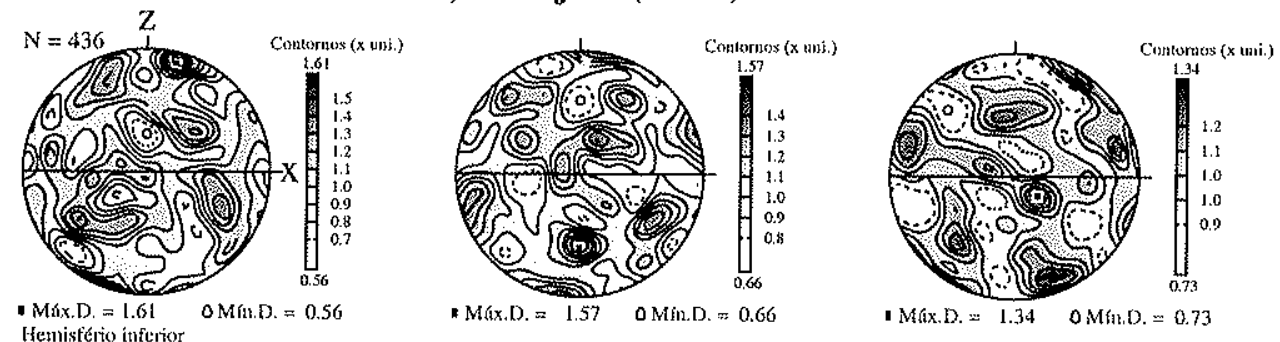

G1, Arc de Bergen
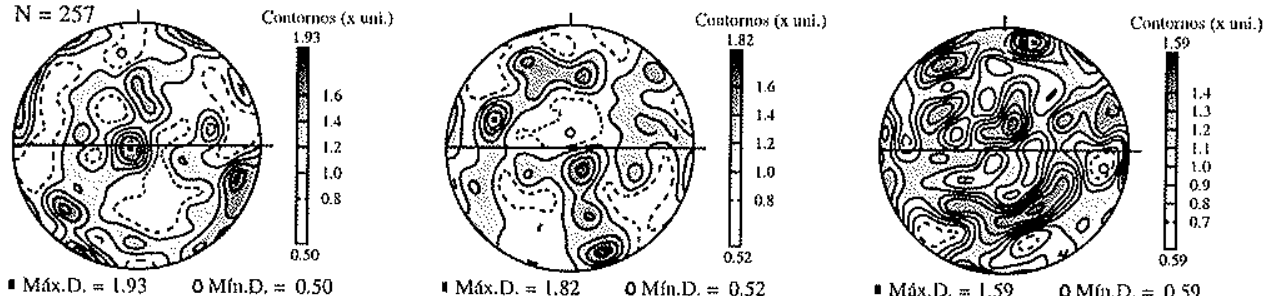

\section{G2, Arc de Bergen}
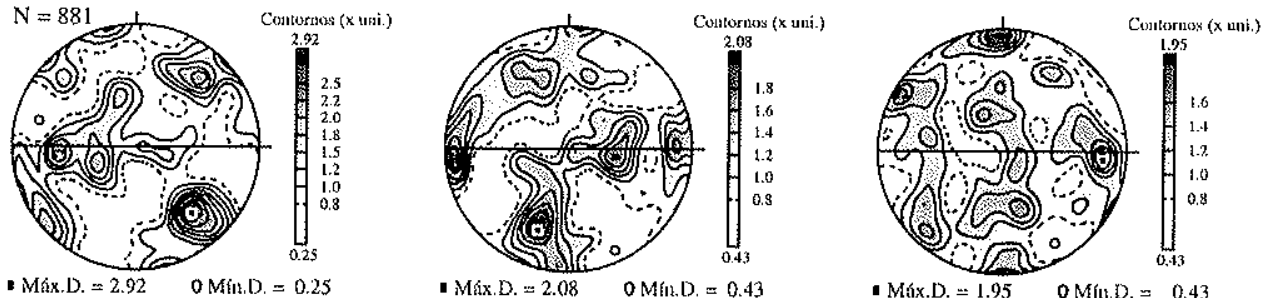

G3, Arc de Bergen
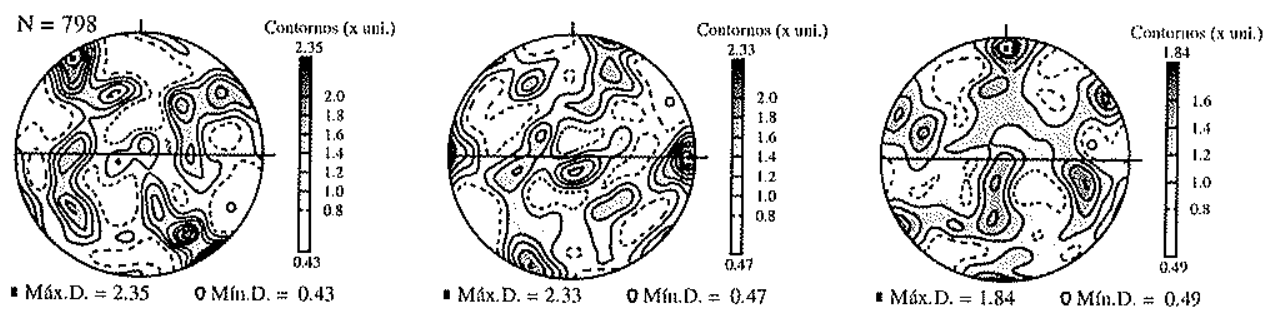

\section{Eclogitos do Mali}

S522, Gourma
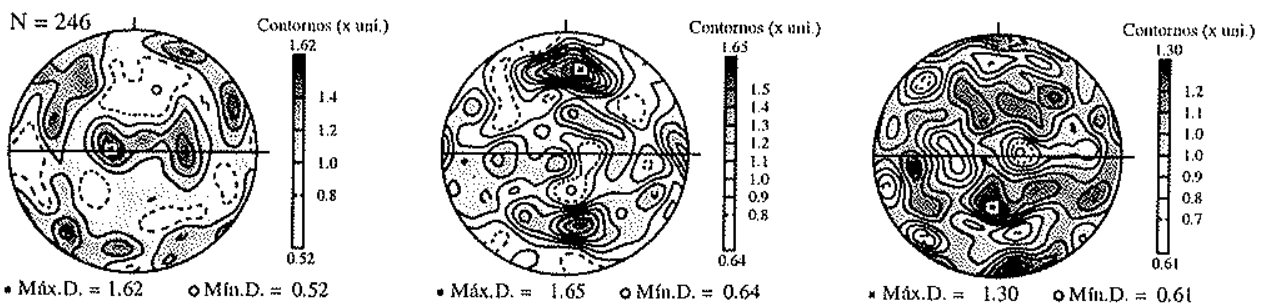


\section{APÊNDICE II \\ DADOS DE PETROLOGIA E COMPOSIÇÃO QUÍMICA DOS GRANULITOS}

\section{Abreviações dos minerais}

$\begin{array}{lll}\text { Alm : almandina } & \text { Gro : grossulária } & \text { Or : ortoclásio } \\ \text { An : anortita } & \text { Grt : granada } & \text { Pl: plagioclásio } \\ \text { And : andesina } & \text { Hbl : hornblenda } & \text { Py : pirita } \\ \text { Bt : biotita } & \text { Ilm : ilmenita } & \text { Pyr: piropo } \\ \text { Byt : bitownita } & \text { Hyp : hiperstênio } & \text { Qtz- } \alpha: \text { quartzo-alfa } \\ \text { Cpx : clinopiroxênio } & \text { Lab : labradorita } & \text { Qtz- } \beta \text { : quartzo-beta } \\ \text { Di : diopsídio } & \text { Ol : oligoclásio } & \\ \text { Fk : feldspato potássico } & \text { Opx : ortopiroxênio } & \end{array}$

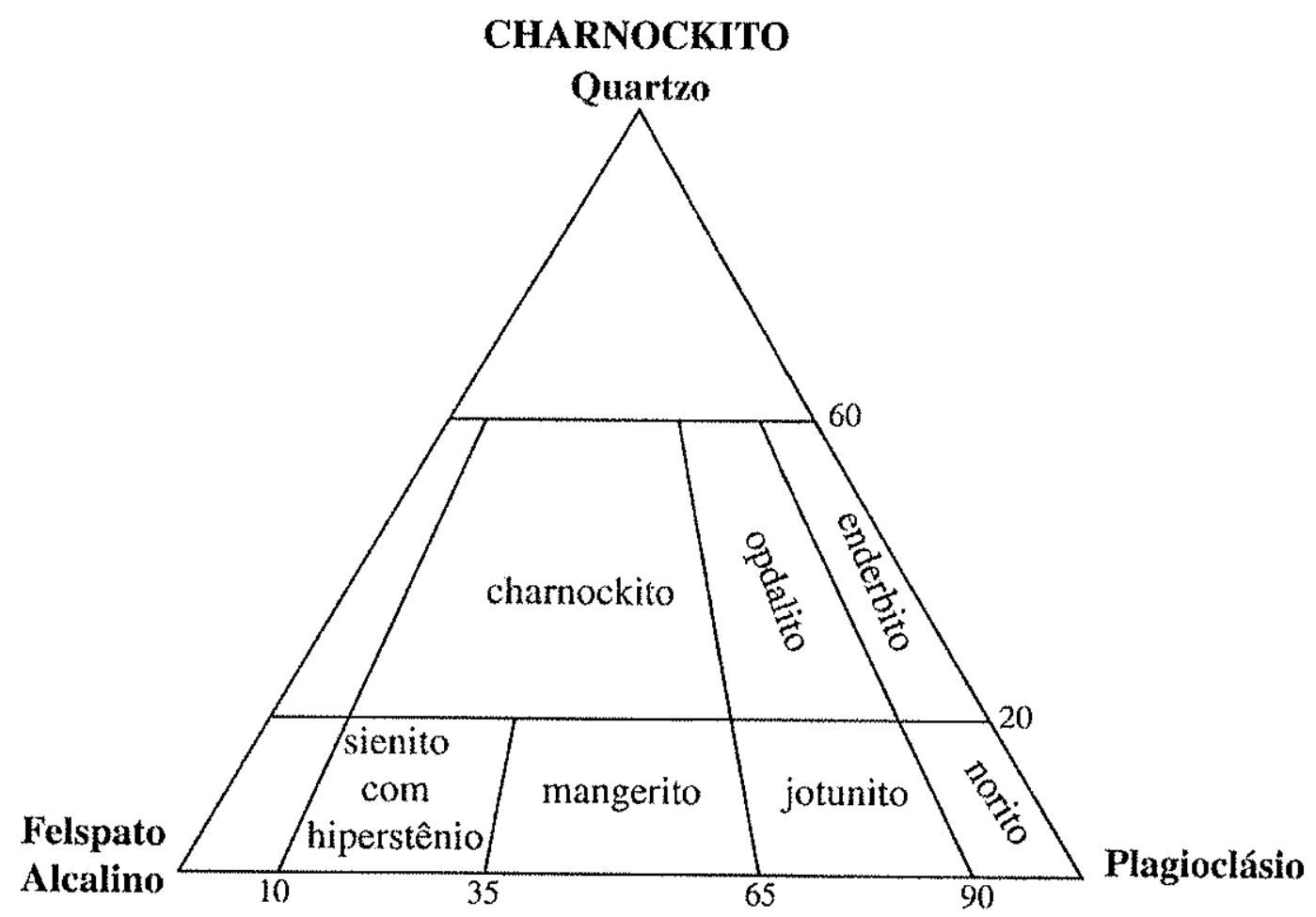

após a tabela de minerais e rochas da Elsevier, compilada por Lof (1982). 


\section{Composição do plagioclásio}

Amostras
RB546
RB559
RB548
RB684
RB614
RB685
RB609A
RB538
RB607A
RB607B
RB484
RB534
RB540
RB689
RB566
RB566B

\begin{tabular}{c}
$N^{\circ}$ Análi \\
\hline 7 \\
9 \\
6 \\
8 \\
6 \\
10 \\
2 \\
8 \\
11 \\
8 \\
5 \\
4 \\
5 \\
10 \\
9 \\
4
\end{tabular}

Anortita $(\%)$
$33<\mathrm{An}<35$
$39<\mathrm{An}<47$
$24<\mathrm{An}<25$
$24<\mathrm{An}<30$
$27<\mathrm{An}<32$
$48<\mathrm{An}<70$
$19<\mathrm{An}<20$
$22<\mathrm{An}<23$
$36<\mathrm{An}<39$
$54<\mathrm{An}<58$
$30<\mathrm{An}<31$
$33<\mathrm{An}<34$
$23<\mathrm{An}<24$
$43<\mathrm{An}<50$
$84<\mathrm{An}<90$
$32<\mathrm{An}<34$

Plagioclásio

Andesina

Andesina

Oligoclásio

Oligoclásio

Oligoclásio - Andesina

Labradorita

Oligoclásio

Oligoclásio

Andesina

Labradorita

Andesina

Andesina

Oligoclásio

Andesina

Bitownita

Andesina

\section{Análises do feldspato - $k$}

\begin{tabular}{|c|c|c|c|c|c|c|c|}
\hline & $\begin{array}{c}\text { RB538 } \\
\text { p117 }\end{array}$ & $\begin{array}{c}\text { RB } 538 \\
\text { p117 }\end{array}$ & $\begin{array}{c}\text { RB538 } \\
\text { p } 118\end{array}$ & $\begin{array}{c}\text { RB538 } \\
\text { pl118 }\end{array}$ & $\begin{array}{c}\text { RB547 } \\
\text { p119' }\end{array}$ & $\begin{array}{c}\mathrm{RB} 684 \\
\mathrm{p} 124\end{array}$ & $\begin{array}{r}\text { RB534 } \\
\text { p103' }\end{array}$ \\
\hline $\mathrm{SiO} 2$ & 65.06 & 65.34 & 65.86 & 65.76 & 65.25 & 65.28 & 63.65 \\
\hline TiO2 & 0.00 & 0.04 & 0.05 & 0.02 & 0.00 & 0.00 & 0.00 \\
\hline $\mathrm{Al} 2 \mathrm{O3}$ & 18.30 & 18.30 & 18.67 & 18.66 & 18.26 & 18.41 & 18.15 \\
\hline $\mathrm{MgO}$ & 0.06 & 0.01 & 0.00 & 0.01 & 0.00 & 0.00 & 0.00 \\
\hline $\mathrm{FeO}$ & 0.19 & 0.10 & 0.03 & 0.04 & 0.03 & 0.03 & 0.00 \\
\hline $\mathrm{MnO}$ & 0.00 & 0.00 & 0.02 & 0.02 & 0.00 & 0.00 & 0.00 \\
\hline $\mathrm{CaO}$ & 0.03 & 0.13 & 0.14 & 0.06 & 0.00 & 0.04 & 0.06 \\
\hline $\mathrm{Na} 2 \mathrm{O}$ & 1.59 & 1.80 & 3.69 & 2.01 & 0.83 & 1.64 & 1.06 \\
\hline $\mathrm{K} 2 \mathrm{O}$ & 14.35 & 14.09 & 11.23 & 13.78 & 15.46 & 14.34 & 15.10 \\
\hline Total & 99.58 & 99.80 & 99.70 & 100.36 & 99.80 & 99.70 & 98.00 \\
\hline \multicolumn{8}{|c|}{ Fórmulas estruturais } \\
\hline $\mathrm{Si}$ & 3.00 & 3.00 & 3.00 & 3.00 & 3.00 & 3.00 & 2.99 \\
\hline $\mathbf{T i}$ & 0.00 & 0.00 & 0.00 & 0.00 & 0.00 & 0.00 & 0.00 \\
\hline $\mathbf{A l}$ & 0.99 & 0.99 & 1.00 & 1.00 & 0.99 & 0.99 & 1.01 \\
\hline Mg & 0.00 & 0.00 & 0.00 & 0.00 & 0.00 & 0.00 & 0.00 \\
\hline $\mathrm{Fe} 2$ & 0.01 & 0.00 & 0.00 & 0.00 & 0.00 & 0.00 & 0.00 \\
\hline Mn & 0.00 & 0.00 & 0.00 & 0.00 & 0.00 & 0.00 & 0.00 \\
\hline $\mathrm{Ca}$ & 0.00 & 0.01 & 0.01 & 0.00 & 0.00 & 0.00 & 0.03 \\
\hline $\mathrm{Na}$ & 0.14 & 0.16 & 0.32 & 0.18 & 0.07 & 0.15 & 0.10 \\
\hline $\mathbf{K}$ & 0.84 & 0.83 & 0.62 & 0.80 & 0.91 & 0.84 & 0.91 \\
\hline Total & 4.98 & 4.99 & 4.95 & 4.98 & 4.97 & 4.98 & 5.04 \\
\hline Xan & 0.00 & 0.01 & 0.01 & 0.00 & 0.00 & 0.00 & 0.00 \\
\hline Xab & 0.14 & 0.16 & 0.33 & 0.18 & 0.08 & 0.15 & 0.10 \\
\hline Xor & 0.85 & 0.83 & 0.66 & 0.82 & 0.92 & 0.85 & 0.90 \\
\hline
\end{tabular}

(*) Fórmulas estruturais calculadas com base em 8 oxigênios 


\section{Análises do anfïbólio}

$\begin{array}{ccccccccc} & \text { RB559 } & \text { RB548 } & \text { RB614 } & \text { RB609A } & \text { RB607 } & \text { RB484 } & \text { RB566 } & \text { RB566 } \\ & \text { P97 } & \text { P99 } & \text { P6 } & \text { P34' } & \text { P26 } & \text { P95 } & \text { P48 } & \text { P48' } \\ \text { SiO2 } & 41.06 & 40.8 & 38.81 & 43.75 & 41.64 & 42.26 & 48.05 & 52.4 \\ \text { TiO2 } & 1.89 & 1.88 & 1.31 & 1.54 & 1.96 & 2.33 & 0.6 & 0.16 \\ \text { A12O3 } & 12.92 & 12.68 & 12.93 & 10.12 & 12.83 & 12.02 & 8.93 & 4.43 \\ \text { Cr2O3 } & 0.00 & 0.00 & 0.00 & 0.00 & 0.00 & 0.00 & 0.00 & 0.00 \\ \text { FeO } & 19.3 & 19.72 & 24.96 & 14.09 & 16.1 & 16.97 & 11.18 & 9.57 \\ \text { MnO } & 0.22 & 0.16 & 0.44 & 0.35 & 0.096 & 0.15 & 0.23 & 0.18 \\ \text { MgO } & 8.19 & 8.22 & 4.69 & 13.12 & 10.71 & 10.47 & 14.92 & 17.66 \\ \text { CaO } & 11.56 & 11.21 & 11.16 & 11.26 & 11.66 & 11.41 & 12.35 & 12.69 \\ \text { Na2O } & 1.36 & 1.47 & 1.42 & 2.02 & 1.41 & 1.59 & 0.77 & 0.39 \\ \text { K2O } & 1.95 & 1.94 & 2.26 & 1.68 & 2.02 & 1.83 & 0.87 & 0.36 \\ \text { H2O } & 1.97 & 1.96 & 1.89 & 2.01 & 2 & 2 & 2.07 & 2.1 \\ \text { Total } & 100.41 & 100.03 & 99.87 & 99.96 & 100.42 & 100.29 & 99.99 & 99.94 \\ \text { Fórmulas estruturais } & & & & & & \\ \text { Si } & 6.242 & 6.24 & 6.136 & 6.52 & 6.237 & 6.349 & 6.945 & 7.459 \\ \text { Ti } & 0.216 & 0.216 & 0.156 & 0.128 & 0.22 & 0.227 & 0.065 & 0.017 \\ \text { Al } & 2.315 & 2.285 & 2.41 & 1.769 & 2.265 & 2.109 & 1.522 & 0.744 \\ \text { Cr } & 0.000 & 0.000 & 0.000 & 0.000 & 0.000 & 0.000 & 0.000 & 0.000 \\ \text { Mg } & 1.856 & 1.874 & 1.105 & 2.996 & 2.391 & 2.347 & 3.215 & 3.747 \\ \text { Fe2 } & 2.454 & 2.522 & 3.301 & 1.749 & 2.017 & 2.077 & 1.352 & 1.14 \\ \text { Mn } & 0.028 & 0.021 & 0.059 & 0.035 & 0.012 & 0.023 & 0.028 & 0.021 \\ \text { Ca } & 1.883 & 1.837 & 1.89 & 1.834 & 1.871 & 1.829 & 1.913 & 1.937 \\ \text { Na } & 0.401 & 0.436 & 0.434 & 0.565 & 0.409 & 0.0464 & 0.216 & 0.107 \\ \text { K } & 0.378 & 0.376 & 0.456 & 0.306 & 0.386 & 0.351 & 0.161 & 0.065 \\ \text { OH } & 2.000 & 2.000 & 2.000 & 2.000 & 2.000 & 2.000 & 2.000 & 2.000 \\ \text { Total } & 17.773 & 17.809 & 17.948 & 17.903 & 17.808 & 17.776 & 17.417 & 17.238 \\ & & & & & & & & \\ \text { XFe } & 0.569 & 0.574 & 0.749 & 0.369 & 0.458 & 0.47 & 0.296 & 0.233\end{array}$




\section{Análises dos piroxênios}

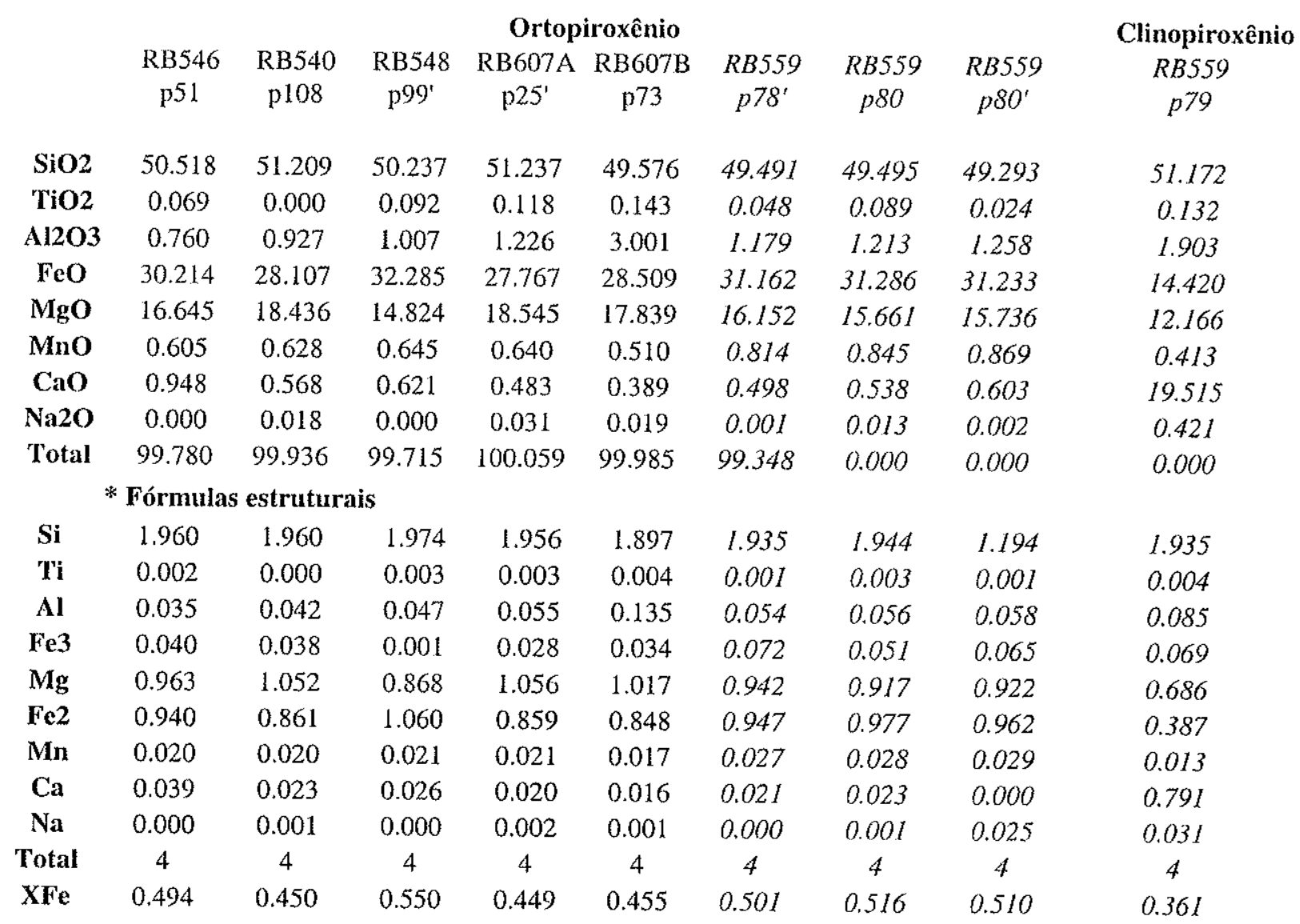

(*) Fórmulas estruturais calculadas com base em 8 oxigênios

Em itálico, os analises utilizados para calcular a temperatura da amostra RB559 (termómetro de Wells, 1977).

\section{Composição das micas}

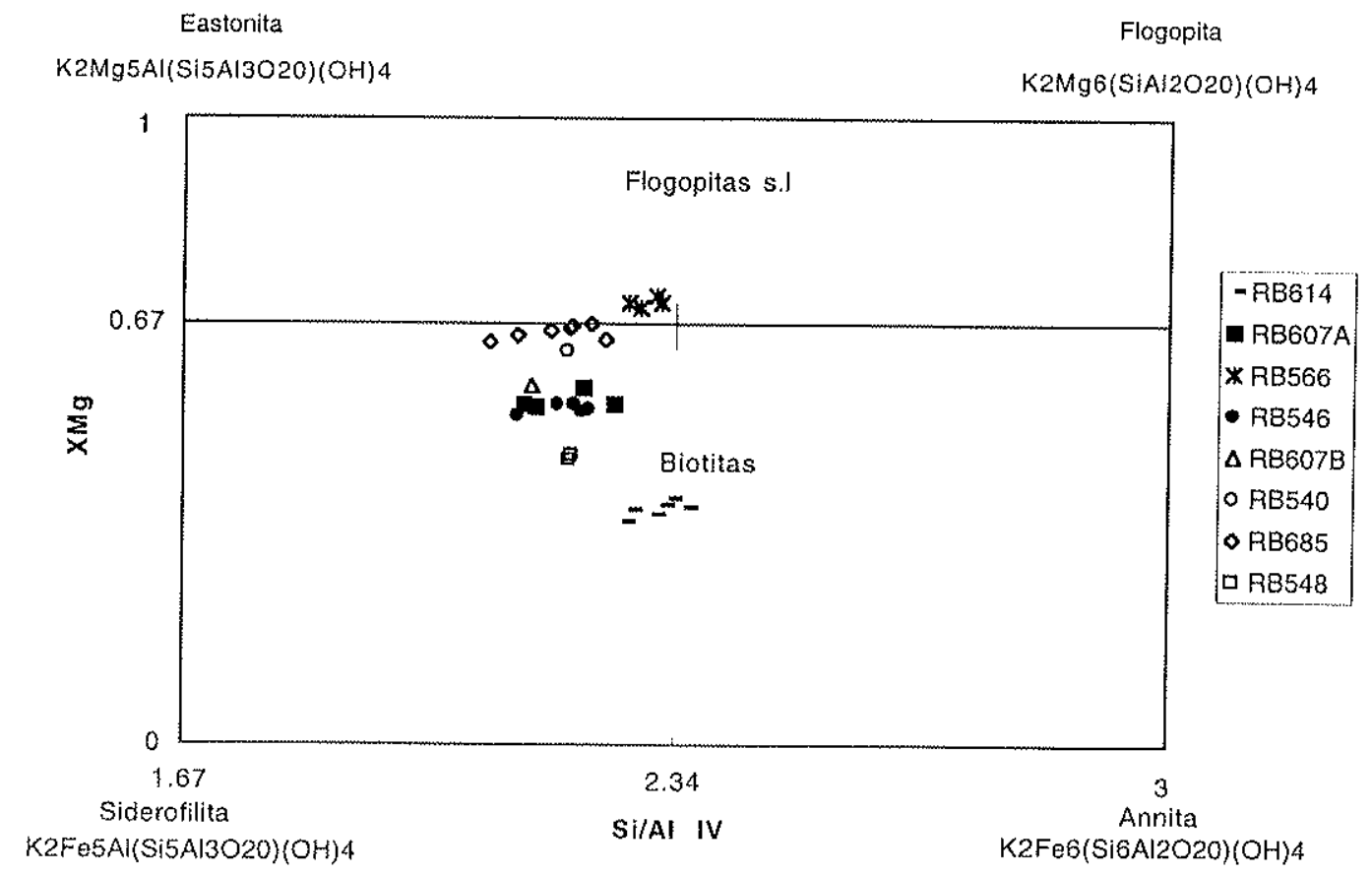




\section{Análises da biotita (RB685)}

$\begin{array}{cccccccc} & \text { pt76 } & \text { pt77 } & \text { pt78 } & p t 79 & p t 80 & p t 82 & \text { pt83 } \\ \text { SiO2 } & 37.04 & 37.43 & 37.00 & 37.36 & 37.54 & 37.29 & 37.54 \\ \text { TiO2 } & 5.12 & 5.18 & 5.41 & 5.18 & 5.03 & 5.42 & 5.27 \\ \text { Al2O3 } & 15.31 & 15.40 & 15.92 & 15.51 & 15.41 & 15.18 & 14.99 \\ \text { MgO } & 14.87 & 15.13 & 14.53 & 14.92 & 15.14 & 14.40 & 14.48 \\ \text { FeO } & 13.13 & 13.93 & 13.78 & 13.36 & 13.14 & 14.33 & 14.22 \\ \text { MnO } & 0.02 & 0.02 & 0.01 & 0.03 & 0.01 & 0.01 & 0.04 \\ \text { CaO } & 0.01 & 0.00 & 0.04 & 0.00 & 0.04 & 0.00 & 0.02 \\ \text { Na2O } & 0.04 & 0.03 & 0.04 & 0.04 & 0.06 & 0.02 & 0.01 \\ \text { K2O } & 9.60 & 9.73 & 9.55 & 9.58 & 9.57 & 9.54 & 9.66 \\ \text { H2O } & 4.04 & 4.09 & 4.08 & 4.07 & 4.08 & 4.06 & 4.06 \\ \text { Total } & 99.16 & 100.95 & 100.35 & 100.05 & 100.01 & 100.27 & 100.29 \\ & * \text { Fórmulas estruturais } & & & & \\ \text { Si } & 2.75 & 2.74 & 2.72 & 2.75 & 2.76 & 2.75 & 2.77 \\ \text { Ti } & 0.29 & 0.29 & 0.30 & 0.29 & 0.28 & 0.30 & 0.29 \\ \mathbf{A l} & 1.34 & 1.33 & 1.38 & 1.35 & 1.34 & 1.32 & 1.30 \\ \mathbf{M g} & 1.65 & 1.65 & 1.59 & 1.64 & 1.66 & 1.58 & 1.59 \\ \mathbf{F e 2} & 0.82 & 0.85 & 0.85 & 0.82 & 0.81 & 0.88 & 0.88 \\ \mathbf{M n} & 0.00 & 0.00 & 0.00 & 0.00 & 0.00 & 0.00 & 0.00 \\ \mathbf{C a} & 0.00 & 0.00 & 0.00 & 0.00 & 0.00 & 0.00 & 0.00 \\ \mathbf{N a} & 0.01 & 0.00 & 0.01 & 0.01 & 0.01 & 0.00 & 0.00 \\ \mathbf{K} & 0.91 & 0.91 & 0.90 & 0.90 & 0.90 & 0.90 & 0.91 \\ \mathbf{O H} & 2.00 & 2.00 & 2.00 & 2.00 & 2.00 & 2.00 & 2.00 \\ \text { Total } & 9.75 & 9.77 & 9.74 & 9.75 & 9.75 & 9.74 & 9.75 \\ & & & & & & & \\ \mathbf{X F e} & 0.33 & 0.34 & 0.35 & 0.33 & 0.33 & 0.36 & 0.36\end{array}$

(*) Fórmulas estruturais calculadas com base em 12 oxigênios 


\section{Análises da granada}

\begin{tabular}{|c|c|c|c|c|c|c|}
\hline & $\begin{array}{c}\text { RB685 } \\
\text { pt66 }\end{array}$ & $\begin{array}{c}\text { RB685 } \\
\text { pt69 }\end{array}$ & $\begin{array}{c}\text { RB685 } \\
\text { pt70 }\end{array}$ & $\begin{array}{c}\mathrm{RB} 685 \\
\mathrm{pt} 71\end{array}$ & $\begin{array}{c}\text { RB607B } \\
\text { Pt71 }\end{array}$ & $\begin{array}{c}\text { RB607B } \\
\text { Pt74 }\end{array}$ \\
\hline $\mathrm{SiO} 2$ & 38.127 & 38.233 & 38.327 & 38.151 & 38.600 & 38.560 \\
\hline TiO2 & 0.026 & 0.110 & 0.023 & 0.000 & 0.040 & 0.000 \\
\hline $\mathrm{Al} 2 \mathrm{O3}$ & 22.004 & 21.828 & 21.916 & 21.753 & 21.450 & 21.680 \\
\hline MgO & 7.635 & 7.957 & 7.743 & 7.262 & 7.041 & 7.190 \\
\hline $\mathrm{FeO}$ & 27.977 & 27.602 & 27.741 & 27.287 & 28.114 & 28.100 \\
\hline Mno & 0.786 & 0.79 & 0.847 & 0.830 & 1.480 & 1.690 \\
\hline $\mathrm{CaO}$ & 3.262 & 2.495 & 2.647 & 3.547 & 4.100 & 2.68 \\
\hline $\mathrm{Na} 2 \mathrm{O}$ & 0.026 & 0.017 & 0.037 & 0.008 & 0.000 & 0.010 \\
\hline $\mathrm{K} 2 \mathrm{O}$ & 0.000 & 0.000 & 0.000 & 0.000 & 0.000 & 0.000 \\
\hline Total & 99.843 & 99.032 & 99.281 & 98.838 & 100.32 & 100.88 \\
\hline \multicolumn{7}{|c|}{ * Fórmulas estruturais } \\
\hline $\mathbf{S i}$ & 2.959 & 2.988 & 2.99 & 2.994 & 3.005 & 2.984 \\
\hline $\mathrm{Ti}$ & 0.002 & 0.006 & 0.001 & 0.000 & 0.002 & 0.000 \\
\hline Al & 2.013 & 2.011 & 2.015 & 2.001 & 1.968 & 1.977 \\
\hline $\mathrm{Fe} 3$ & 0.069 & 0.003 & 0.007 & 0.002 & 0.018 & 0.057 \\
\hline $\mathbf{M g}$ & 0.883 & 0.927 & 0.900 & 0.849 & 0.755 & 0.829 \\
\hline $\mathrm{Fe} 2$ & 1.747 & 1.801 & 1.802 & 1.788 & 1.812 & 1.818 \\
\hline $\mathrm{Mn}$ & 0.052 & 0.052 & 0.056 & 0.055 & 0.097 & 0.111 \\
\hline $\mathrm{Ca}$ & 0.271 & 0.209 & 0.221 & 0.298 & 0.342 & 0.222 \\
\hline $\mathrm{Na}$ & 0.004 & 0.003 & 0.006 & 0.001 & 0.000 & 0.002 \\
\hline $\mathbf{K}$ & 0.000 & 0.000 & 0.000 & 0.000 & 0.000 & 0.000 \\
\hline Total & 8 & 8 & 8 & 8 & 8 & 8 \\
\hline $\mathrm{XFe}$ & 0.664 & 0.660 & 0.667 & 0.678 & 0.706 & 0.687 \\
\hline Xalm & 0.59 & 0.60 & 0.60 & 0.60 & 0.60 & 0.61 \\
\hline Xpyr & 0.30 & 0.31 & 0.30 & 0.28 & 0.25 & 0.28 \\
\hline Xgro & 0.09 & 0.07 & 0.07 & 0.10 & 0.11 & 0.07 \\
\hline Xspe & 0.02 & 0.02 & 0.02 & 0.02 & 0.03 & 0.04 \\
\hline
\end{tabular}

Análises no centro do mineral

(*) Fórmulas estruturais calculadas com base em 12 oxigênios

O programa do calculo das fórmulas estruturais é aquele de M. Guiraud (1994) 